FERNANDA RODRIGUES CUGOLA

Análise fenótipo-patogênica da infecção pelo vírus Zika em células humanas neurais in vitro

São Paulo

2018 
FERNANDA RODRIGUES CUGOLA

Análise fenótipo-patogênica da infecção pelo vírus Zika em células humanas neurais in vitro

Tese de Doutorado apresentada ao Programa de Pós-Graduação em Anatomia dos Animais Domésticos e Silvestres da Faculdade de Medicina Veterinária e Zootecnia da Universidade de São Paulo para a obtenção do título de Doutor em Ciências

Departamento:

Cirurgia

Área de concentração:

Anatomia dos Animais Domésticos e Silvestres

Orientador:

Profa. Dra. Patrícia C. B. Beltrão-Braga

São Paulo

2018 
Autorizo a reprodução parcial ou total desta obra, para fins acadêmicos, desde que citada a fonte.

\section{DADOS INTERNACIONAIS DE CATALOGAÇÃO NA PUBLICAÇÃO}

(Biblioteca Virginie Buff D’Ápice da Faculdade de Medicina Veterinária e Zootecnia da Universidade de São Paulo)

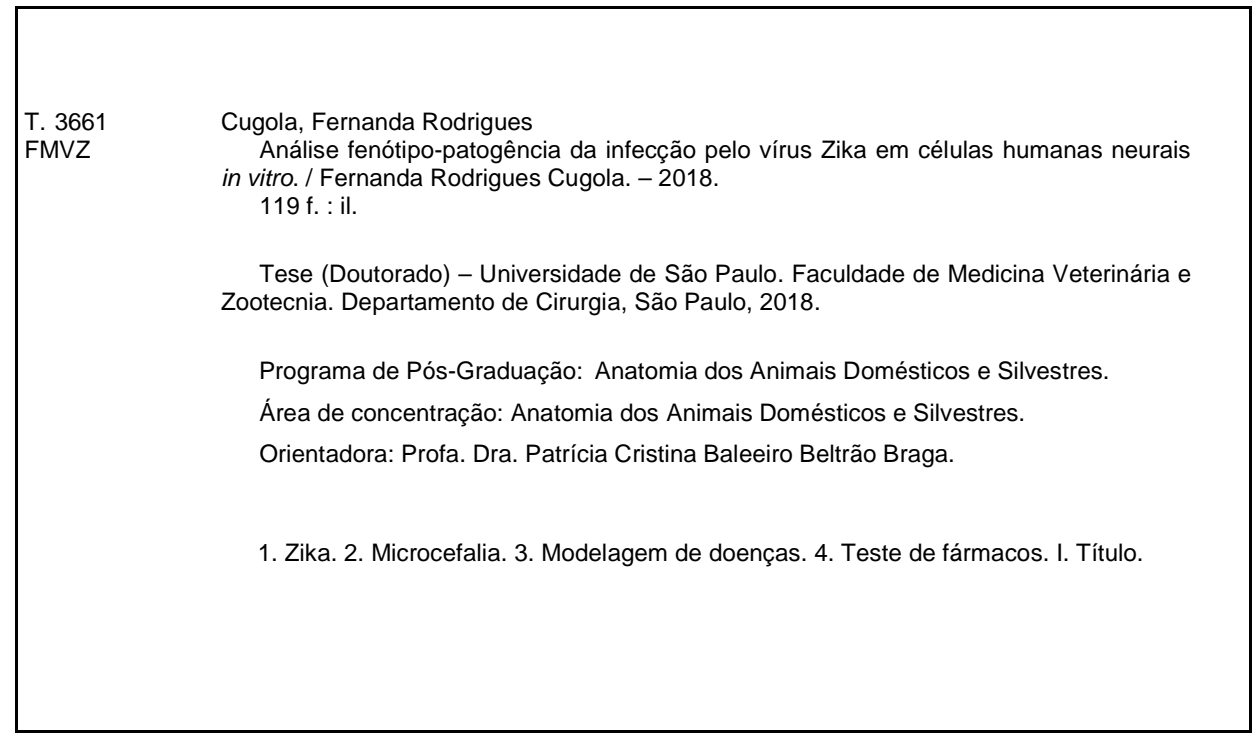

Ficha catalográfica elaborada pela bibliotecária Maria Aparecida Laet, CRB 5673-8, da FMVZ/USP. 
IImo(a). Sr(a).

Responsável: Patricia Cristina Baleeiro Beltrão Braga

Área: Anatomia Dos Animais Domésticos E Silvestres

Patricia C B Beltrão Braga (orientador)

Título do projeto: "Análise fenótipo-patogênica da infecção pelo vírus Zika em células humanas neurais in vitro".

\section{Parecer Consubstanciado da CEUA FMVZ/USP}

A Comissão de Ética no Uso de Animais da Faculdade de Medicina Veterinária e Zootecnia da Universidade de São Paulo, na reunião de 15/03/2017, ANALISOU e APROVOU o protocolo de estudo acima referenciado. A partir desta data, é dever do pesquisador: 1. Comunicar toda e qualquer alteração do protocolo.

2. Comunicar imediatamente ao Comitê qualquer evento adverso ocorrido durante o desenvolvimento do protocolo.

3. Os dados individuais de todas as etapas da pesquisa devem ser mantidos em local seguro por 5 anos para possível auditoria dos órgãos competentes.

4. Relatórios parciais de andamento deverão ser enviados anualmente à CEUA até a conclusão do protocolo.

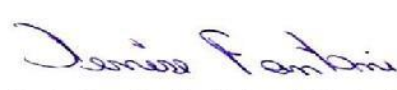

Profa. Dra. Denise Tabacchi Fantoni Presidente da Comissão de Ética no Uso de Animais Faculdade de Medicina Veterinária e Zootecnia da Universidade de São Paulo

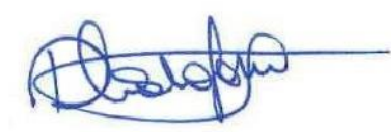

Roseli da Costa Gomes Secretaria Executiva da Comissão de Ética no Uso de Animais Faculdade de Medicina Veterinária e Zootecnia da Universidade de São Paulo 


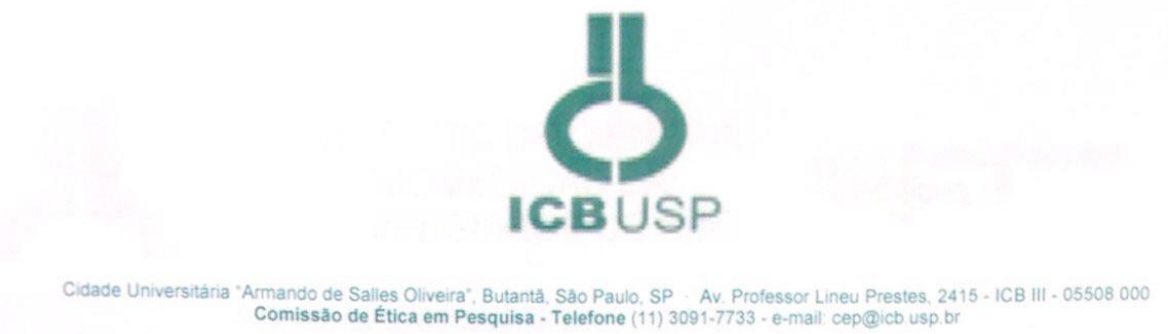

Comissão de Ética em Pesquisa - Telefone (11) 3091-7733. - e-mail cep@ich usp br

Of.CEPSH.058.2016

São Paulo, 23 de setembro de 2016.

\section{Assunto: Autorização para Biorrepositório}

A Comissão de Ética em Pesquisa com Seres Humanos aprovou o Cadastro do Biorrepositório de amostras células tronco derivadas da polpa dentária humana de pacientes com Transtorno do Espectro do Autismo e controles, de acordo com a proposta de armazenamento enviada em 12/09/2016.

Todas as amostras somente serão coletadas e armazenadas após o consentimento por escrito do participante de pesquisa, após assinatura em TCLE específico, autorizando a guarda e uso do material. Lembramos ainda que, a qualquer tempo e sem quaisquer ônus ou prejuízos, o participante da pesquisa, ou seu representante legal, pode retirar o consentimento de guarda e utilização do material biológico armazenado em Biobanco ou Biorrepositório, valendo a desistência a partir da data de formalização desta. A retirada do consentimento será formalizada por manifestação, por escrito e assinada, pelo participante da pesquisa ou seu representante legal, cabendo-lhe a devolução das amostras existentes (Res. 441/10, art. 10).

Cabe ao pesquisador responsável o gerenciamento do material biológico humano armazenado em Biorrepositório. Qualquer alteração na composição do biorrepositório (tanto por inclusão de novas amostras ou exclusão de amostras) deve ser informada a esta Comissão para readequação do cadastro.

Informo ainda, que o material poderá ser utilizado em novas pesquisas desde que estas sejam previamente aprovadas pela Comissão de Ética deste Instituto.

Esta autorização tem validade de 10 anos a partir desta data, podendo ser renovada conforme determina o artigo 12 da Resolução no 441/10, mediante justificativa e relatório das atividades de pesquisa desenvolvidas com o material durante o período.

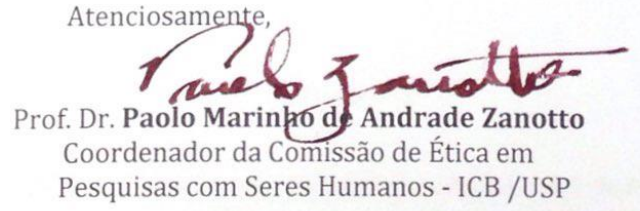

Ilma. Senhora

Profa. Dra. Patrícia Cristina Baleeiro Beltrão Braga

Departamento de Cirurgia

Faculdade de Medicina Veterinária e Zootecnia - USP

Comissão de Ética em Pesquisa com Seres Humanos do Instituto de Ciências Biomédicas / USP Aprovada pela Comissão Nacional de Ética em Pesquisa - CONEP, em 10 de fevereiro de 1998. 
FOLHA DE AVALIAÇÃO

Autor: CUGOLA, Fernanda Rodrigues

Título: Análise fenótipo-patogênica da infecção pelo vírus Zika em células humanas neurais in vitro

Tese de Doutorado apresentada ao Programa de Pós-Graduação em Anatomia dos Animais Domésticos e Silvestres da Faculdade de Medicina Veterinária e Zootecnia da Universidade de São Paulo para obtenção do titulo de Doutor em Ciências

Data:

\section{Banca Examinadora}

Prof. Dr.

Instituição: Julgamento:

Prof. Dr.

Instituição: Julgamento:

Prof. Dr.

Instituição: Julgamento:

Prof. Dr.

Instituição: Julgamento:

Prof. Dr.

Instituição: Julgamento: 


\section{AGRADECIMENTOS}

Gostaria de agradecer inicialmente à Faculdade de Medicina Veterinária e Zootecnia da Universidade de São Paulo, pela oportunidade de realização deste curso de pósgraduação e desenvolvimento desta pesquisa.

Ao Instituto de Ciências Biomédicas da Universidade de São Paulo por abrir as suas portas para a realização desse trabalho.

À Prof. Dr. Patricia Braga. Muito obrigada pela oportunidade, por toda a confiança depositada em mim, por sempre me apoiar e aceitar as minhas idéias, por todos os ensinamentos e incentivos, me dando a oportunidade de crescer cada vez mais. Obrigada por confiar no meu trabalho e me proporcionar a experiência de crescer profissionalmente e acima de tudo pela amizade sempre presente.

Ao Prof. Dr. José Roberto Kfoury Jr, Prof. Dr. Maria Angélica Miglino, Daura, Rose e Ronaldo pela disposição, apoio e dedicação ao programa de pós graduação.

Ao Prof. Dr. Alysson Muotri, por acreditar e confiar em mim e permitir que eu crescesse científicamente. Meu respeito e admiração por fornecer a inspiração e as bases que me prepararam para a pós-graduação.

Aos amigos da UCSD, Pri, Cléber, Helen, Pinar, Angela, Herai, Charlie, Allan, Earl, Ginny, Cassiano, Ana, Jackie, Leon e a todos que passaram por lá, por me ensinarem tudo sobre cultura celular e iPSC e me apoiarem profissionalmente e pessoalmente.

Aos Prof. Dr. Jean Pierre, Prof. Dr. Edson Durigon, Dr. Danielle Bruna, Dr. Prof. Paolo Zanotto, Prof. Dr. Giuseppe Palmisano, Dr. Livia Rosa, Dr. Paulo Leite, Prof. Dr. Carlos 
Menck, Dr. Veridiana Munford, Prof. Dr. Henning Hulrich, Prof. Dr. Alexandre Bruni Cardoso.

Aos colegas de laboratório, Anita, Cecília, Fabi, Gra, João, Larissa, Natália, Rafa, pela amizade, parceria e troca de experiências diárias e em especial, Kátia e Cris; o apoio de vocês foi imprescindível.

À CAPES, pela bolsa concedida durante o Doutorado.

Aos meus pais e irmã, pela torcida inabalável, apoio e amor incondicionais, consolos, conselhos, ombros e ouvidos.

Ao meu marido André, simplesmente por você ser você. 
"When you realize the value of all life, you dwell less on what is past and concentrate more on the preservation of the future."

Dian Fossey 


\section{RESUMO}

CUGOLA, F. R. Análise fenótipo-patogênica da infecção pelo vírus Zika em células humanas neurais in vitro. [A phenotypic and pathogenic analysis of Zika virus infection in human neural cells in vitro]. 2018. $120 \mathrm{f}$. Tese (Doutorado em Ciências) - Faculdade de Medicina Veterinária e Zootecnia, Universidade de São Paulo, São Paulo, 2018.

O Zika vírus (ZIKV) é um flavivírus transmitido pelo mosquito Aedes aegypti e que se espalhou rapidamente pelas Américas, causando uma epidemia no Brasil em 2015. Um número crescente nos casos de infecções veio acompanhado de um aumento no número de fetos e bebês nascidos com microcefalia, levando a um chamado de emergência mundial de saúde. Históricamente, o ZIKV não havia causado infecções de destaque em humanos e a reermegência dessa ameça viral associada à defeitos do nascimento foi logo relacionada à evolução e consequente distinção entre os genótipos virais, o original Zika africano e seu descendente Zika asiático, que chegou ao Brasil. A hipótese da cepa brasileira do ZIKV ser a causadora de microcefalia e de outros defeitos do nascimento ganhou mais respaldo após a identificação do vírus em amostras de tecido cerebral e líquido amniótico de fetos. Posteriormente, a associação direta entre microcefalia e a síndrome congênita com o ZIKV foi confirmada por meio da aplicação de modelos biológicos experimentais que se revelaram susceptíveis à infecção viral, como células do sistema nervoso central em sistemas 2D e 3D in vitro e camundongos prenhês. Esse trabalho teve como objetivo investigar a infecção da cepa brasileira do ZIKV (ZIKVBR) em diferentes células humanas neurais in vitro diferenciadas a partir de células-tronco pluripotentes induzidas, além de criar uma plataforma para teste de fármacos in vitro contra o vírus. Nossos resultados comprovaram a susceptibilidade e permissividade celular à infecção do ZIKVBR em células neuronais e, em especial, progenitoras neurais, causando morte celular por apoptose. Além disto, quando células progenitoras neurais foram cultivadas em suspensão, formando neuroesferas, o ZIKVBR foi capaz de causar uma redução na população de células, gerando uma anormalidade morfológica semelhante à microcefalia. Além do mais, quando células progenitoras neurais infectadas com ZIKVBR foram diferenciadas em neurônios maduros, a análise da sinaptogênese revelou que esses neurônios apresentavam uma menor densidade de puncta sináptica, indicando um comprometimento no funcionamento das sinapses que pode 
estar contribuindo para os problemas associados com a síndrome congênita do ZIKV. Por fim, o tratamento dessas células com a droga Sofosbuvir, um inibidor de RNA polimerase dependente de RNA aprovado para uso clínico, foi capaz de resgatar NPCs e neurônios apoptóticos. Em suma, nossos dados indicam que o ZIKVBR infecta preferencialmente células progenitoras neurais, replicando-se eficientemente e causando morte por apoptose nessas células e neurônios maduros diferenciados de células progenitoras neurais infectadas apresentam uma menor desidade de puncta sináptica. Finalmente, a reutilização de compostos farmacêuticos já aprovados para uso clínico pode acelerar o tratamento para indivíduos infectados pelo ZIKV onde a prevenção já não é mais opção, como no caso de mulheres grávidas.

Palavras-chave: Zika. Microcefalia. Modelagem de doenças. Teste de fármacos. 
ABSTRACT

CUGOLA, F. R. A phenotypic and pathogenic analysis of Zika virus infection in human neural cells in vitro. [Análise fenótipo-patogênica da infecção pelo vírus Zika em células humanas neurais in vitro]. 2018. 120 f. Tese (Doutorado em Ciências) Faculdade de Medicina Veterinária e Zootecnia, Universidade de São Paulo, São Paulo, 2018.

Zika virus (ZIKV) is a mosquito-borne flavivirus transmitted by Aedes aegypti that has rapidly spread through the Americas, causing a widespread epidemic in Brazil in 2015. A increasing number of infection cases was followed by a rise in the number of fetuses and babies born with microcephaly, leading to a global health emergency call. Up to then, ZIKV had not caused meaningful infections in humans and the reemergency of this viral threat associated with birth defects was soon related to viral genotype mutations and its consequent distinction from the original african Zika strain to its descendent asian Zika strain, which reached Brazil. The hypotesis of the brazilian ZIKV strain being responsible for microcephaly and other birth defects gained support after the isolation and identification of the virus in samples of cerebral tissue and amniotic fluid of fetuses. Subsequently, the direct association between microcephaly and congenital syndrome with ZIKV was confirmed through the application of biologic experimental models which proved susceptible to viral infection, as for cells from the central nervous system cultured in 2D and 3D models as well as pregnant mice. The aim of this study was to investigate the brazilian ZIKV strain (ZIKVBR) infection in different human neural cells in vitro differentiated from induced pluripotent stem cells, as well as creating a platform for in vitro drug testing with antiviral capabilities. Our results showed cellular infection susceptibility and permissiveness to ZIKVBR in neurons and, specially, neural progenitor cells, displaying cell death by apoptosis. Futhermore, when neuronal progenitor cells cultured in suspension, forming neurospheres, were infected with $\mathrm{ZIKV} \mathrm{KR}^{\mathrm{BR}}$, it caused a reduction in cell population, displayed by evident morphological abnormalities resembling to microcephaly. Additionally, when neural progenitor cells infected with ZIKVBR were diferentiated further into mature neurons, synaptogenesis analysis revealed these neurons displayed fewer synaptic puncta density, indicating a compromise in synapse functioning that may be contributing to problems associated with ZIKV congenital syndrome. Moreover, cell treatment with Sofosbuvir, a RNA polymerase RNAdependent inhibitor approved for clinical use, was able to rescue apoptotic NPCs and 
neurons. In summary, our results reveal that ZIKVBR preferentially infects neural progenitor cells, efficiently replicating itself and causing death by apoptosis in these cells and mature neurons differentiated from infected neural progenitor cells display reduced synaptic puncta density. Lastly, the repurpose of FDA approved compounds may aid in accelerating treatment for infected individuals whose prevention is no longer an option, as it is for pregnant women.

Keywords: Zika. Microcephaly. Disease modelling. Drug testing. 


\section{SUMÁRIO}

1 INTRODUÇÃO

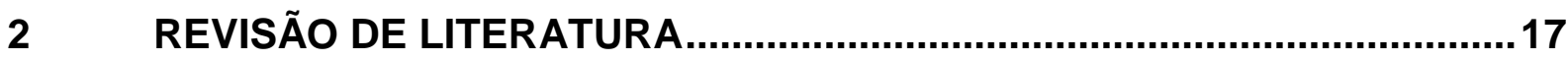

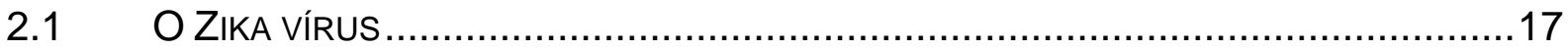

2.2 As IPSC NA MODELAGEM DE DOENÇAS QUE ACOMETEM O SISTEMA NERVOSO

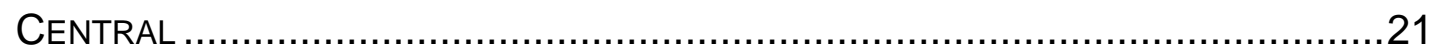

2.3 AS IPSC NA MODELAGEM DE INFECÇÕES VIRAIS .......................................25

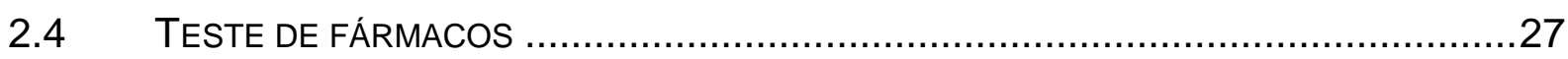

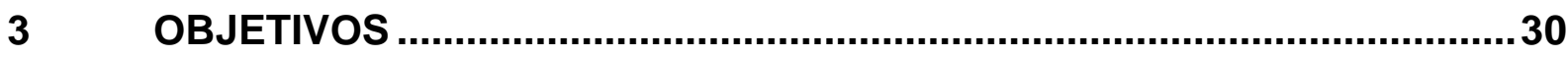

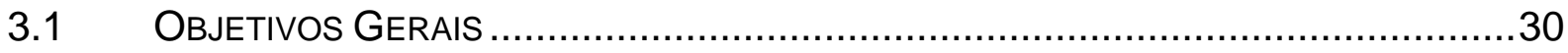

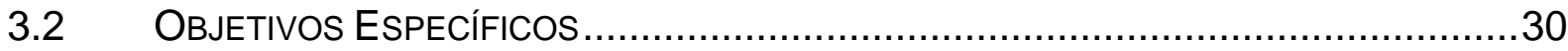

$4 \quad$ MATERIAIS E MÉTODOS

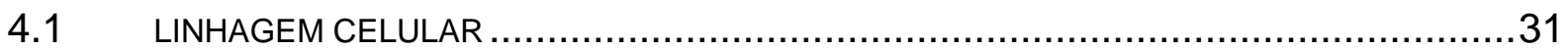

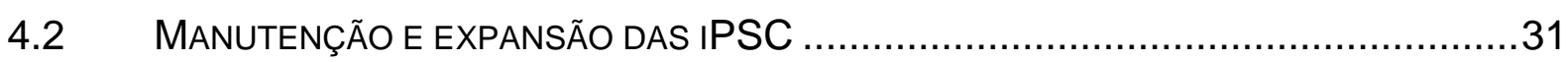

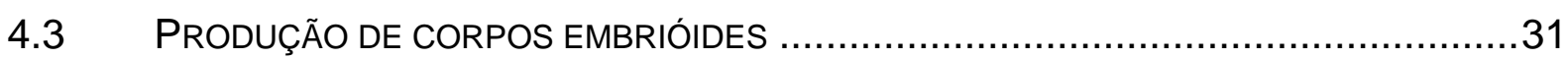

4.4 PRODUÇÃO DE ROSETAS E CÉLULAS PROGENITORAS NEURAIS (NPCS) .................32

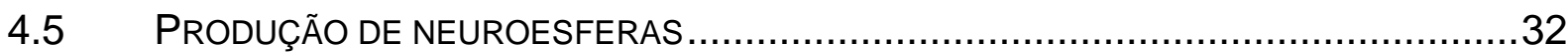

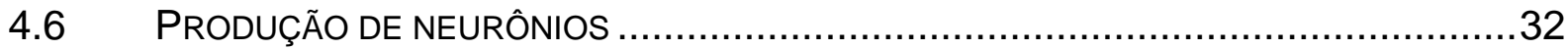

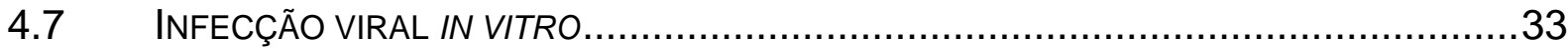

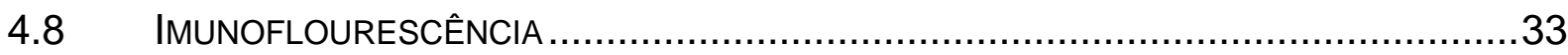

4.9 CONTAGEM DE SINAPSES COLOCALIZADAS (PUNCTA) .......................................

4.10 EXTRAÇÃo de RNA E ENSAIOS DE PCR EM TEMPO REAL (QPCR) ….................35

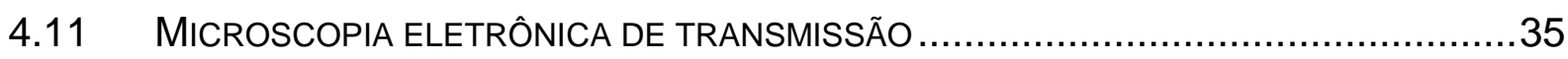

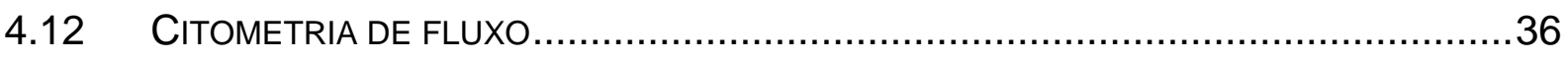

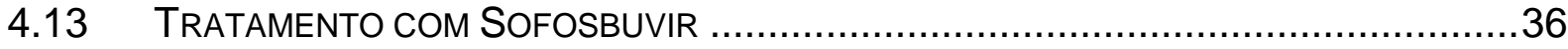

$5 \quad$ RESULTADOS

5.1 INFECÇÃO PELO ZIKV EM CÉLULAS NEURAIS IN VITRO.......................................38

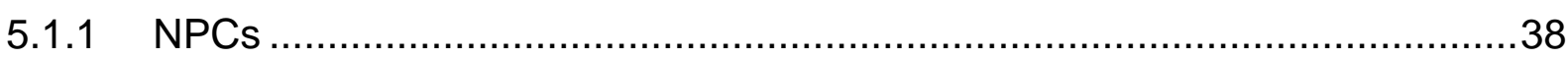

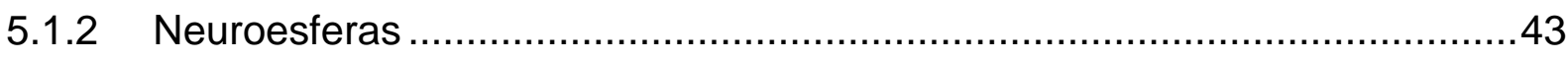

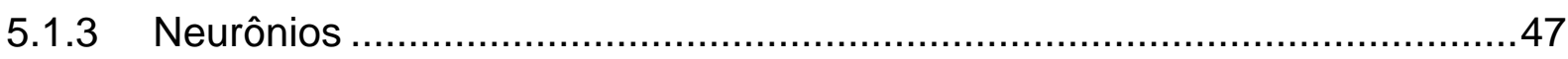

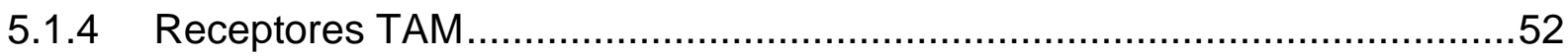

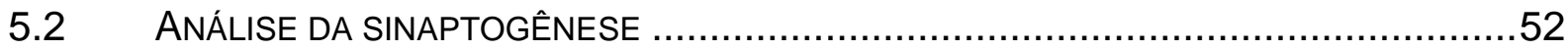

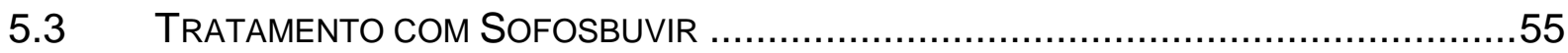




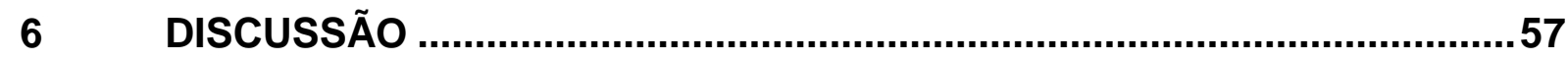

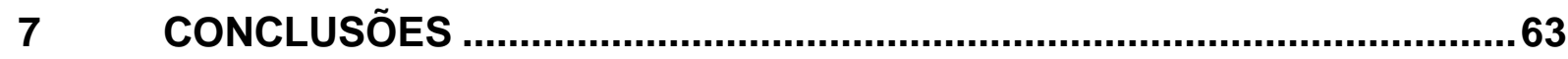

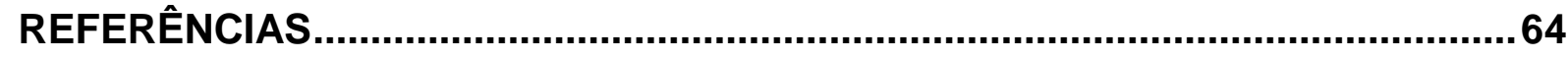

APÊNDICES 
O Zika vírus (ZIKV) é um arbovírus pertecente ao gênero Flavivirus (família Flaviviridae) e foi descrito pela primeira vez em 1947 após ser isolado de macacos Rhesus da floresta de Zika na Uganda (DICK; KITCHEN; HADDOW, 1952). Por muitas décadas, o ZIKV causou apenas casos esporádicos em humanos. Entretanto, em 2007, após uma epidemia na ilha de Yap na Micronésia, constatou-se por análises de sequenciamento genético, uma divergência da linhagem ancestral comum, separando o genótipo viral em Africano e Asiático (LANCIOTTI et al., 2008). De 2013 a 2015, o ZIKV continuou espalhando-se pelos arquipélagos do Sudeste Asiático e o Oceano Pacífico, chegando ao Brasil e mais tarde se propagando pela América do Sul e Central (FARIA et al., 2016). Os sintomas típicos da infecção do ZIKV são amenos e limitados, como febre, artralgia, conjuntivite e manchas vermelhas na pele (MACNAMARA, 1954; BEARCROFT, 1956). No Brasil, o ZIKV foi associado à malformações congênitas, incluindo a microcefalia e ao desenvolvimento posterior de doenças neurológicas severas, como a síndrome de Guillain-Barré (CAO-LORMEAU et al., 2016). Atualmente, o termo Síndrome Congênita da Zika é adotado para reunir um grupo de alterações neurológicas, oculares, auditivas e esqueléticas, além da microcefalia, observado em fetos e bebês infectados com ZIKV (COSTELLO et al., 2016). Apesar de toda a evidência clínica (BRASIL et al., 2016b; CALVET et al., 2016; MLAKAR et al., 2016), faltava ainda a comprovação experimental direta demonstrando que a cepa brasileira do ZIKV (ZIKVBR) era a causadora dos defeitos observados no nascimento de bebês infectados durante o período pré-natal.

Para tanto, lançamos mão das células-tronco pluripotentes induzidas (iPSC) para investigar a relação direta da infecção do ZIKV com a microcefalia. As iPSC têm sido extensivamente aplicadas na modelagem de doenças, em especial neurológicas (MARCHETTO; WINNER; GAGE, 2010; RUSSO et al., 2018), e no campo da virologia, o emprego da tecnologia de iPSC tem ajudado a elucidar as interações célula-vírus, além de fornecer uma plataforma para o desenvolvimento de novas estratégias antivirais (TREVISAN et al., 2015). Além do mais, a habilidade única da iPSC de se diferenciar em células-alvo de uma patologia, gera oportunidades para o teste de medicamentos específicos in vitro (BELTRÃO-BRAGA et al., 2013). 
Apresentamos nesse trabalho a investigação da infecção do ZIKV em células progenitoras neurais e neurônios diferenciados a partir de iPSC, provendo um modelo mecanicista na elucidação da patologia do ZIKV no neurodesenvolvimento humano. Por conseguinte, analisamos as consequências da infecção viral na neurogênese, buscando predizer um efeito fenotípico do vírus no sistema nervoso central. Além do mais, usamos nosso modelo como uma plataforma para testar os efeitos de um fármaco no combate aos impactos nocivos da infecção do ZIKV. 


\section{REVISÃO DE LITERATURA}

\subsection{O ZIKA VÍRUS}

O Zika vírus (ZIKV) é um arbovírus pertencente ao gênero Flavivirus (Família Flaviviridae), que também engloba outros vírus patogênicos humanos como o vírus da dengue, da febre amarela, do Nilo Ocidental, entre outros. Assim como demais membros da família, o ZIKV é um vírus RNA envelopado de cadeia simples e senso positivo com um genoma de $10.7 \mathrm{~kb}$ que codifica uma única poliproteína que é clivada em três proteínas estruturais ( $\mathrm{C}$ - capsídeo; prM/M - precursor de membrana; E envelope) e sete proteínas não estruturais (NS1, NS2A, NS2B, NS3, NS4A, NS4B, e NS5) (LINDENBACH; RICE, 2003). Em humanos, uma infecção típica por ZIKV causa sintomas limitados e amenos, como febre, dor de cabeça, manchas vermelhas na pele, conjuntivite e mialgia (MACNAMARA, 1954; BEARCROFT, 1956; SIMPSON, 1964). Geralmente, os sintomas desaparecem após 3-7 dias, mas em alguns poucos casos, a artralgia pode persistir por meses e evoluir para complicações neurológicas como a síndrome de Guillain-Barré, uma polineuropatia desmielinizante inflamatória, representada por fraqueza muscular acometendo pernas e braços (OEHLER et al., 2014; CAO-LORMEAU et al., 2016).

O ZIKV foi descrito pela primeira vez em 1947, após ser isolado de macacos Rhesus da floresta de Zika na Uganda, sendo subsequentemente isolado de mosquitos Aedes africanus, coletados na mesma região em 1948 (DICK; KITCHEN; HADDOW, 1952). Durante os anos seguintes à sua identificação, o ZIKV foi repetidamente isolado de Aedes spp. na África (Ae. africanus) e na Malásia (Ae. aegypti), implicando esses mosquitos como vetores endêmicos ou enzóoticos (WEINBREN; WILLIAMS, 1958; HADDOW et al., 1964; MARCHETTE; GARCIA; RUDNICK, 1969). Atualmente, já é sabido que o ZIKV também pode ser transmitido sexualmente (D'ORTENZIO et al., 2016; MCCARTHY, 2016).

Análises sorológicas em humanos levaram à identificação da infecção pelo ZIKV no Egito, Nigéria, Uganda, Índia, Malásia, Indonésia, Paquistão, Tailândia, Vietnã e Filipinas entre os anos 1950 e 1960 (MARCHETTE; GARCIA; RUDNICK, 1969) e estudos de vigilância do arbovírus na África possibilitaram o isolamento do 
vírus em humanos entre os anos 1960-70, mesmo na ausência de episódios de epidemia (SIMPSON, 1964; MOORE et al., 1975; FAGBAMI, 1979), sugerindo a difusão do ZIKV da África para o sudeste da Ásia.

Até o século $X X$, o ZIKV não havia causado infecções de destaque em humanos. Entretanto, em 2007, um "surto da febre do Zika" acometeu a ilha de Yap na Micronésia onde ficou constatado por sequenciamento genético, uma divergência da linhagem ancestral comum com distribuição no Sudeste asiático e o Pacífico, separando os genótipos virais em Asiático e Africano (LANCIOTTI et al., 2008). Dentre 2007 e 2014, o ZIKV continuou espalhando-se pelos arquipélagos do Sudeste Asiático e o Oceano Pacífico, (DUFFY et al., 2009; CAO-LORMEAU et al., 2014) e em 20152016, chegou à América do Sul e Central e o Caribe.

No Brasil, um número crescente de casos de microcefalia foi inicialmente reportado em outubro de 2015, após o reconhecimento da transmissão do ZIKV no país no começo do mesmo ano (BRASIL et al., 2016b; DE OLIVEIRA et al., 2016). A reemergência dessa ameaça viral, associada ao grande número de casos de microcefalia e má formações do sistema nervoso central reportados em diferentes regiões geográficas, levou a Organização Mundial da Saúde a declarar um aviso de emergência mundial de saúde pública no começo de 2016. O Ministério da Saúde chegou a reconhecer 196.976 casos prováveis da infecção pelo vírus no Brasil, com transmissão autóctone e alta incidência em 22 dos 27 estados brasileiros (BRASIL, 2016a) e, de acordo com dados da Organização Mundial da Saúde e do Centro de Controle e Prevenção de Doenças, infecções pelo ZIKV já ocorreram localmente em mais de 60 países (WHO, 2016).

Atualmente, o termo a Síndrome Congênita da Zika (SCZ) é adotado para definir um conjunto único e específico de defeitos do nascimento observados em fetos e bebês infectados com ZIKV antes do nascimento (COSTELLO et al., 2016). Além da microcefalia, a SCZ inclui um amplo espectro de achados sistêmicos como anormalidades neurológicas, oculares, auditivas e esqueléticas (MOORE et al., 2017). Contudo, as alterações neurológicas são consideradas a marca registrada da SCZ.

A microcefalia é definida como uma redução no perímetro cefálico menor ou inferior a -2 desvios-padrão abaixo da média para a idade gestacional e sexo (BRASIL. MINISTÉRIO DA SAÚDE. SECRETARIA DE ATENÇÃO À SAÚDE., 2016). Acreditase que a microcefalia seja resultado de uma redução da população de células da glia radial e células-tronco neurais no cérebro em desenvolvimento, seja por diferenciação 
prematura ou morte celular (BARKOVICH et al., 2012; LANCASTER et al., 2013; GUERRINI; DOBYNS, 2014). Casos de microcefalia associados à infecções virais têm sido reportados e incluem os vírus da chikungunya, Nilo Ocidental, citomegalovirus, entre outros (NAKAO; CHIBA, 1970; O'LEARY et al., 2006; GÉRARDIN et al., 2014; TEISSIER et al., 2014).

A hipótese da infecção do ZIKV durante a gravidez ser a causadora de microcefalia e de outras malformações congênitas ganhou apoio após a identificação do ZIKV no tecido cerebral e no líquido aminiótico de fetos (CALVET et al., 2016; MARTINES et al., 2016; MLAKAR et al., 2016), sugerindo que o vírus fosse capaz de atravessar a membrana placental. O primeiro trimestre de gestação é crucial para o desenvolvimento neurológico e uma infecção pelo ZIKV durante esse período é mais provável em afetar o sistema nervoso central (SNC) (CAUCHEMEZ et al., 2016). Atualmente, o vírus já foi isolado de urina (GOURINAT et al., 2015), saliva (MUSSO et al., 2015a), sêmen (MUSSO et al., 2015b), sangue (LUSTIG et al., 2016).

Os primeiros alvos durante a transmissão do ZIKV na picada do mosquito, os fibroblastos da pele e os queratinócitos da epiderme, são altamente permissivos ao vírus (HAMEL et al., 2015). Neurônios e astrócitos em cérebros de camundongos também se demonstraram passíveis de infecção, induzindo a degeneração do hipocampo e a necrose de células piriformes sete dias após a infecção (BELL; FIELD; NARANG, 1971). Mais recentemente, foi demonstrado que o ZIKV infecta células progenitoras neurais (NPCs) derivadas de células-tronco pluripotentes humanas in vitro, causando morte celular por apoptose (TANG et al., 2016). Esse estudos foram feitos usando a linhagem MR-766 do ZIKV Africano, isolada em Uganda em 1947, que compartilha $87-90 \%$ de similaridade na sequência com o vírus presente na Polinésia e no Brasil (LANCIOTTI et al., 2008; FAYE et al., 2014; FARIA et al., 2016). No entanto, como não há relatos de malformações congênitas nos isolados africanos, houve uma necessidade de se estudar a associação do ZIKV com a microcefalia e anomalias congênitas com isolados das localidades afetadas, como o ZIKV do Brasil.

Um tropismo por neurônios imaturos e NPCs proveram a primeira indicação aos mecanismos relacionados à neuropatologia do ZIKV e sublinham a necessidade de mais pesquisas na neuropatologia relacionada ao ZIKV (TANG et al., 2016). Embora a evidência de que o ZIKV é capaz de cruzar a membrana placentária e infectar o feto ser amplamente reconhecida, o mecanismo usado pelo vírus ainda não está claro. Um estudo com um feto microcefálico, cuja gestação foi interrompida, 
mostrou macrófagos da placenta (células de Hofbauer) e células sinciciais infectadas com o ZIKV (JURADO et al., 2016). O ZIKV consegue se manter viável dentro de macrófagos e essas células poderiam servir como "cavalos de tróia", cruzando a membrana placentária carregadas de vírus (MESCl et al., 2018a). Outro trabalho mostrou que diferentes células da placenta e da membrana amniótica podem ser infectadas pelo ZIKV durante o segundo e o terceiro trimestre da gestação através dos receptores TIM1 e TAM, aparentemente os responsáveis pela entrada do vírus nestas células (TABATA et al., 2016). Em conjunto, esses achados sugerem múltiplas rotas para a transmissão vertical do ZIKV.

A implicação da participação das proteínas TIM e TAM como fatores de entrada na infecção viral já foi demonstrada para o vírus da dengue, promovendo a infecção pelo acoplamento e, possívelmente, internalização das partículas virais em culturas de células humanas e células primárias visadas por flavivírus (MEERTENS et al., 2012; PERERA-LECOIN et al., 2013). Em humanos, a família de receptores TIM está envolvida na fagocitose de células apoptóticas e na regulação da imunidade inata e adaptativa (RAVICHANDRAN, 2011), e a expressão ectópica desses receptores foi implicada no aumento à permissividade da infecção por diferentes flavivírus, como o vírus da dengue, do Nilo Ocidental e da febre amarela, permitindo estabelecer uma forte correlação entre a expressão endógena desse receptor e a permissividade à infecção em diferentes linhagens celulares humanas (PERERA-LECOIN et al., 2013).

Os receptores TAM (Tyro-3, Axl e Mertk) são proteínas tirosina quinases com funções biológicas relevantes, em especial na resposta imunológica, como promover a fagocitose de células em apoptose e inibir a inflamação. TYRO3 é encontrado essencialmente no sistema nervoso central, enquanto Mertk e AXL são amplamente expressos (LEMKE; ROTHLIN, 2008; LEMKE, 2013). A ativação dessa tirosina quinase é acoplada à subsequente ativação da via da PI3K/AKT em muitas células, regulando a sobrevivência celular e a mobilização do citoesqueleto de actina necessária para a remoção de células apoptóticas por macrófagos. Células que expressam os receptores TAM associados a receptores de interferon tipo 1, como células dendríticas, macrófagos e outras células sentinelas do sistema imune, a ativação da via PI3K/AKT é obscurecida por uma ativação mais forte da via de sinalização de JAK/STAT, que leva à ativação dos genes que codificam a supressão da sinalização de citocinas, inibindo a resposta inflamatória por um ciclo de feedback negativo iniciadas pelos receptores do tipo toll e vias de sinalização de interferon 1 
(ROTHLIN et al., 2007; LEMKE; ROTHLIN, 2008; LEMKE, 2013). As duas moléculas ligantes de TAM - as proteínas Gas6 e Pros1 - permitem que elas associem-se à fosfatidilserina, externalizadas da membrana celular em células apoptóticas, para a ativação dos receptores TAM. Diversos vírus envelopados exibem fosfatidilserina na superfície de sua membrana externa, como os flavivírus, que usam dos receptores TAM para a invasão celular por um processo denominado "mimetismo apoptótico" (LEMKE, 2013; PERERA-LECOIN et al., 2013) e o ZIKV consegue suprimir a sinalização de interferon 1 a partir da degradação proteasomal do ativador transcripcional STAT2 pela sua proteína não estrutural NS5 em humanos (GRANT et al., 2016). Suprimir a sinalização de interferon 1, um potente agente antiviral, é um mecanismo que os vírus exploram repetidamente como meios de evasão imune (DIAMOND, 2003).

Recentemente, essa família de receptores foi implicada como a via de invasão celular pelo ZIKV, e o AXL, em especial, foi proposto como principal candidato a receptor pra infecção do ZIKV durante a neurogênese (HAMEL et al., 2015; NOWAKOWSKI et al., 2016; MEERTENS et al., 2017) e embora o receptor TIM-1 por si só contribua pouco para a infecção do ZIKV, a sua expressão teve um efeito aditivo sobre a eficácia da entrada viral mediada por AXL (HAMEL et al., 2015). Contudo, o papel desempenhado pelos receptores TIM e TAM durante a infecção viral e patogênese continua desconhecido. Impedir o mecanismo de entrada dos vírus através desses receptores parece uma forma efetiva de inibir a infecção viral (HAMEL et al., 2015; TABATA et al., 2016; PERSAUD et al., 2018).

\subsection{AS IPSC NA MODELAGEM DE DOENÇAS QUE ACOMETEM O SISTEMA NERVOSO CENTRAL}

O importante desenvolvimento da tecnologia de reprogramação de células somáticas e a geração das chamadas células-tronco pluripotentes induzidas (em inglês induced pluripotent stem cells, iPSC) (TAKAHASHI; YAMANAKA, 2006), possibilitou revolucionar os estudos de doenças genéticas e idiopáticas, em especial doenças neurodegenerativas e do neurodesenvolvimento, como Alzheimer, Parkinson, Esquizofrenia, Autismo e outras, (PARK et al., 2008; MARCHETTO et al., 
2010; CHEUNG et al., 2011; ISRAEL et al., 2012; GRIESI-OLIVEIRA et al., 2015; RUSSO et al., 2018) proporcionando ainda, uma plataforma para teste de fármacos (BELTRÃO-BRAGA et al., 2013; MULLARD, 2015) e uma fonte de células autólogas visando terapia regenerativa (MARCHETTO; WINNER; GAGE, 2010). A Figura 1 ilustra a reprogramação celular e suas possíveis aplicações.

Figura 1 - Esquema representativo do processo de reprogramação e aplicações

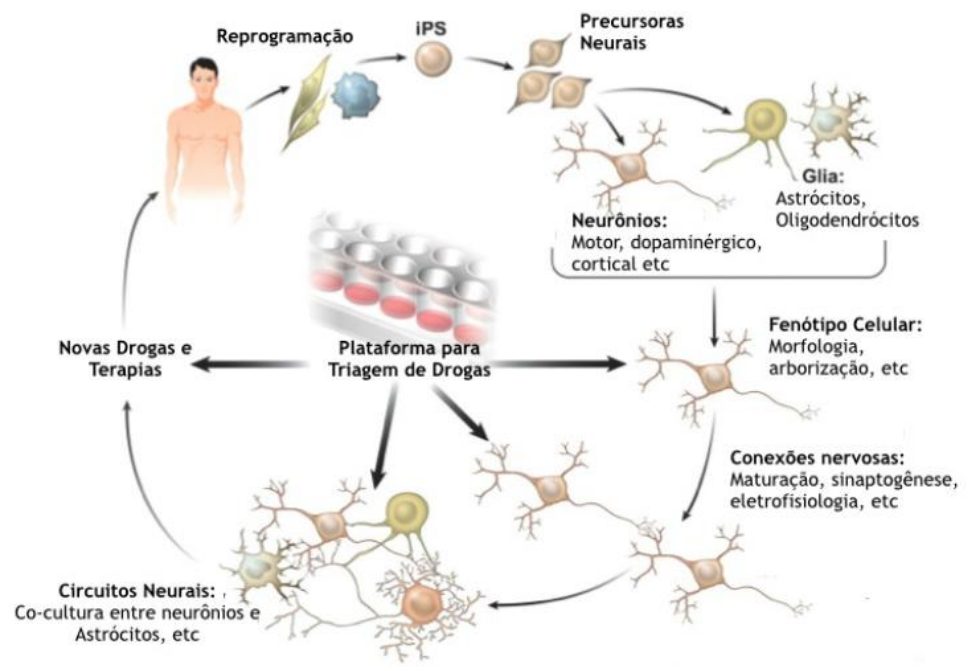

Fonte: (MARCHETTO; WINNER; GAGE, 2010, adaptado por CUGOLA, F.R., 2017)

Legenda: Uma representação simplificada da reprogramação de células diferenciadas em células-tronco pluripotentes induzidas (iPSC) e a consequente diferenciação em diversos tipos celulares como progenitoras neurais (NPCs), neurônios e glia. As células retêm o genoma do paciente doador tornando possível a triagem de fármacos e potencialmente, o transplante autólogo de células.

Atualmente, iPSC humanas têm sido geradas a partir de uma variedade de células somáticas, como fibroblastos, células sanguíneas periféricas, SHEDs, e diferenciadas em quase todos os tipos celulares, em especial os tipos afetados em certas doenças, como cardiomiócitos e neurônios. Células iPSC derivadas de pacientes expressam o genótipo completo e os demais fatores, que mesmo desconhecidos, contribuem para uma patologia, além de representarem um sistema não-invasivo, versátil e ético (KIM, 2015).

A reprogramação de células somáticas em iPSC foi demonstrada pela primeira vez por Takahashi e Yamanka, através da indução da expressão ectópica de quatro fatores de transcrição de células-tronco (Oct4, Sox2, Klf4 e c-Myc) em fibroblastos murinos e posteriormente humanos, conferindo a essas células uma capacidade 
ilimitada de auto renovação e proliferação, além de darem origem à células dos três tecidos germinativos (TAKAHASHI; YAMANAKA, 2006; TAKAHASHI et al., 2007). A tecnologia rapidamente se espalhou e, não muito depois, começaram a sair os primeiros trabalhos usando neurônios diferenciados a partir de iPSC na modelagem de doenças genéticas, como atrofia muscular espinhal (EBERT et al., 2009) e síndrome de Rett (MARCHETTO et al., 2010). Nesse último trabalho, a tecnologia foi usada pela primeira vez para testar fármacos nos neurônios diferenciados de iPSC de pacientes de Rett, observando-se a reversão do fenótipo neuronal alterado, estabelecendo assim uma nova plataforma de teste de drogas para o tratamento da doença. Atualmente, diversos protocolos usando diferentes métodos de reprogramação se encontram disponíveis na literatura (SCHLAEGER et al., 2015), assim como protocolos para diferenciação de iPSC em vários tipos celulares, incluindo neurônios (STERNECKERT; REINHARDT; SCHOLER, 2014).

Mais recentemente, o desenvolvimento dos organóides cerebrais, estruturas que desenvolvem identidades regionais organizadas, trouxe uma nova perspectiva aos estudos do neurodesenvolvimento com uso de iPSC, incluindo a microcefalia (LANCASTER et al., 2013; QIAN et al., 2016; GABRIEL et al., 2017), permitindo uma melhor compreensão das interações entre diferentes tipos celulares. Em nível celular, os organóides cerebrais demonstram um alto grau de similaridade com o cérebro humano nos estágios iniciais de desenvolvimento. Uma ilustração representando o desenvolvimento do cerébro humano e do organóide é apresentada na Figura 2. 
Figura 2 - Comparação do desenvolvimento cerebral in vivo e in vitro

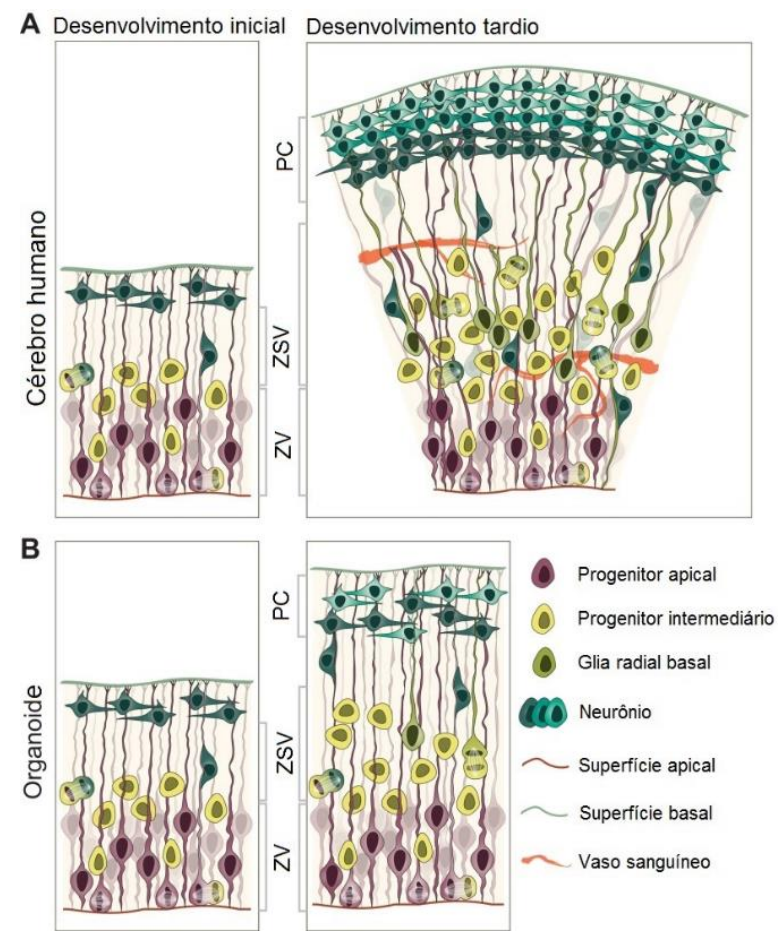

Fonte: (KELAVA; LANCASTER, 2016, adaptado por CUGOLA, F.R., 2018).

Legenda: Uma representação simplificada da complexidade biológica celular do desenvolvimento cerebral in vivo e do organóide cerebral in vitro. Os estágios iniciais (esquerda) possuem um nível morfológico similar de complexidade. Os estágios tardios (direita) diferem em tamanho da placa cortical e na diversidade e complexidade das populações progenitoras neurais. Note a ausência de vascularização (laranja) no organóide, uma ZSV reduzida e uma organização rudimentar nas camadas neuronais. ZV - zona ventricular, ZSV - zona subventricular, PC - placa cortical.

Análises comparativas da expressão gênica entre os organóides e o cérebro humano em desenvolvimento demonstraram que o modelo in vitro reproduz de forma extraordinária o desenvolvimento inicial do cérebro in vivo, com relatos de que o desenvolvimento in vitro compara-se até as semanas gestacionais 19-24 (PAŞCA et al., 2015; QIAN et al., 2016). Levando em consideração todas essas similaridades observadas entre os modelos de desenvolvimento cerebral in vivo e in vitro, essa nova tecnologia abre uma nova janela de estudos de doenças que acometem o cérebro humano, assim como para entender melhor os mecanismos biológicos básicos do desenvolvimento.

O primeiro estudo publicado descrevendo o uso de organóides cerebrais foi na investigação de uma doença do neurodesenvolvimento, a microcefalia primária 
(LANCASTER et al., 2013). Organóides desenvolvidos a partir de iPSC derivadas de um paciente com microcefalia exibiam diferenciação neural prematura e eram substancialmente menores do que os organóides controles. Além disso, esses organóides tinham uma orientação irregular do eixo da glia radial, que caracteriza um fenótipo complexo associado com sintomas específicos da doença. Mais recentemente, os organóides cerebrais também foram usados na investigação do autismo, uma doença idiopática, revelando que células progenitoras neurais primitivas tinham um ciclo celular mais curto, proliferando em excesso, como também um aumento na produção de neurônios GABAérgicos e no número de sinapses (MARIANI et al., 2015). A identificação desse conjunto de caracterísiticas, pelo menos para um subtipo de autismo, abre oportunidade para a criação de um diagnóstico pré-natal específico para essa síndrome, com drogas que possam eliminar os fenótipos anormais e/ou aliviar os sintomas, destacando a relevância da investigações em patologias do neurodesenvolvimento com organóides.

\subsection{AS IPSC NA MODELAGEM DE INFECÇÕES VIRAIS}

A possibilidade de diferenciar iPSCs em diversos tipos celulares proporcionou um sistema celular de fácil acesso e de grande potencial para a investigação de infecções virais quanto ao tropismo, patogênese, latência e interação com o hospedeiro humano. As iPSCs têm sido empregadas na modelagem da infecção viral e já foram reportadas para o citomegalovírus, herpes simples, varicella zoster, hepatite B e C (revisto em TREVISAN et al., 2015), dengue (LANG et al., 2016) e mais recentemente, Zika (CUGOLA et al., 2016; GARCEZ et al., 2016; NOWAKOWSKI et al., 2016; QIAN et al., 2016; TANG et al., 2016).

Pesquisas em virologia se baseiam amplamente no uso de células imortalizadas ou transformadas, devido às limitações impostas pela disponibilidade e cultura de células primárias humanas (SCHWARTZ et al., 2012). Apesar de todas as vantagens apresentadas no emprego de iPSC em relação às linhagens celulares tradicionais, ainda são poucos os estudos na literatura de infecção viral em comparação aos estudos de doenças hereditárias ou degenerativas. Entretanto, os resultados obtidos na virologia são singulares e sugerem que a tecnologia das iPSC 
pode ser muito útil para muitas outras aplicações na modelagem viral - como interações celulares, no estudo das consequências da patologia viral específica em pacientes e avaliação da resposta a terapias antivirais, além de como plataforma para o desenvolvimento de novas estratégias antivirais.

De destaque, pesquisas feitas com os vírus da hepatite $\mathrm{C}(\mathrm{HCV})$ foram pioneiras no emprego da tecnologia das iPSC para a modelagem da infecção viral. Células progenitoras e hepatócitos diferenciados derivados de iPSC mostraram-se passíveis de infecção pelo HCV e eram capazes de secretar partículas virais no meio sobrenadante (ROELANDT et al., 2012; SCHWARTZ et al., 2012; WU et al., 2012), contornando os desafios de cultura de hepatócitos primários devido a disponibilidade limitada, qualidade variável e curto prazo para uso. Outro exemplo de modelagem de doença infecciosa foi feita com o citomegalovírus humano (CMV), que pode causar defeitos do nascimento e microcefalia em recém-nascidos. O CMV tem habilidade de se manter latente no hospedeiro por longos períodos, e modelos de células-tronco embrionárias (em inglês embryonic stem cells, ESC) e iPSC demonstraram que a infecção pelo CMV resultou em infecção latente das mesmas; entretanto, a diferenciação em células endodérmicas (PENKERT; KALEJTA, 2013) e progenitoras neurais e neurônios (D’AIUTO et al., 2012) resultou em infecção lítica, sugerindo que o mesmo fenômeno aconteça in vivo, uma vez que humanos têm células-tronco adultas viáveis ao longo da vida, permitindo que o CMV persista latente nessas células por muito tempo.

O emprego da tecnologia das iPSC permitiu um grande e rápido avanço às pesquisas sobre a infecção do ZIKV em humanos, frente a epidemia e ao crescente número de casos de microcefalia no Brasil recentemente. Os primeiros estudos investigando a infecção pelo ZIKV em células neurais derivadas de iPSC foram feitos usando a linhagem MR-766 do ZIKV Africano, que compartilha 87-90\% de similaridade na sequência com o vírus presente na Polinésia e no Brasil (FAYE et al., 2014; FARIA et al., 2016). Tang et al., forneceu a primeira pista de que o ZIKV infectava NPCs mais eficientemente do que iPSC ou neurônios imaturos (TANG et al., 2016), desregulando ciclo celular e causando morte celular por apoptose. Entretanto, nosso grupo foi o primeiro a comparar os efeitos das duas cepas do ZIKV, o ZIKVBR e o MRF-766 (ZIKVAF), em culturas celulares em monocamada e em suspensão, organóides e modelos murinos (CUGOLA et al., 2016). Em nossos achados, dados constituintes dessa tese, o ZIKVBR aparentava manifestar efeitos deletérios mais 
severos em nossos modelos do que o ZIKVAF, sendo que as NPCs e as neuroesferas eram infectadas mais eficientemente pelo ZIKVBR, levando a um aumento de morte celular por apoptose e reduzindo o crescimento nos modelos $3 \mathrm{D}$, consolidando a hipótese de ligação entre a infecção do ZIKV e defeitos do nascimento (CUGOLA et al., 2016). Em tempo, o uso de organóides cerebrais tem trazido grande conhecimento aos efeitos do ZIKV no desenvolvimento do cérebro fetal (MING; TANG; SONG, 2016). Pesquisas empregando organóides revelaram que a infecção do ZIKV resultou em uma redução no tamanho total do organóide, uma diminuição na espessura da camada cortical, alteração na proliferação das células na zona ventricular e alargamento dos ventrículos, mimetizando características semelhantes à microcefalia observada em crianças infectadas por transmissão vertical (CUGOLA et al., 2016; GARCEZ et al., 2016; QIAN et al., 2016; GABRIEL et al., 2017). Ademais, a infecção de organóides com dengue tipo 2 (GARCEZ et al., 2016) ou febre amarela (CUGOLA et al., 2016) não causou nenhum prejuízo, sugerindo que os danos causados pela infecção do ZIKV não é uma condição geral da família dos flavivírus.

\subsection{TESTE DE FÁRMACOS}

Diante da crescente ameaça imposta pela dissipação do ZIKV, algumas pesquisas têm focado em medidas profiláticas no combate à infecção do ZIKV através do reposicionamento de compostos aprovados pela agência norte-americana FDA (Food and Drug Administration) (BARROWS et al., 2016; RETALLACK et al., 2016; $X U$ et al., 2016), enquanto outras pesquisas têm focado no desenvolvimento de vacinas (ABBINK et al., 2016; LAROCCA et al., 2016). Embora iniciativas a imunizações sejam de grande relevância, há uma necessidade em se desenvolver estratégias clínicas para o tratamento de indivíduos infectados com o ZIKV, em especial mulheres grávidas que não possuem mais a opção de prevenção. No momento, não há nenhuma droga aprovada para o tratamento ou prevenção da infecção do ZIKV.

Pesquisas empregando grandes bibliotecas de fármacos aprovados pela FDA conseguiram identificar compostos capazes de diminuir a infecção do ZIKV em diferentes linhagens de células humanas (BARROWS et al., 2016; RETALLACK et al., 
2016; XU et al., 2016). Os compostos identificados foram desde drogas antivirais já estabelecidas, assim como outras sem conhecida capacidade antiviral, como os antibióticos daptomicina (BARROWS et al., 2016) e azitromicina (RETALLACK et al., 2016) e o vermífugo niclosamida (XU et al., 2016), sendo este último bem tolerado e seguro a fetos, podendo potencialmente ser administrado a mulheres grávidas. Outro estudo de triagem de drogas, identificou 5 candidatos com alta atividade contra 0 ZIKV: lovastatina, fluoruracila, azauridina, kitasamicina e palonosetron, pertencentes a diferentes classes, com diferentes estruturas e consequentemente, diferentes mecanismos de bloqueio à infecção do ZIKV (PASCOALINO et al., 2016). Outros estudos identificaram vários compostos com amplo espectro antiviral e inibidores de síntese de pirimidina que suprimem os efeitos citopáticos causados pelo ZIKV (ADCOCK et al., 2017). Entretanto, ainda não foram feitos testes in vivo dessas drogas.

Diversos análogos de nucleotídeo, como nucleosídeo 2'-C metilados 7DMA e 2CMC, Ribavirina e Favipiravir apresentam atuação antiviral contra o ZIKV in vitro, inibindo a replicação do vírus e a atividade da RNA polimerase dependente de RNA (EYER et al., 2016). A droga antiviral Sofosbuvir (SOF), um inibidor de RNA polimerase dependente de RNA aprovado para uso clínico, ganhou grande destaque recentemente ao mostrar que protege contra a infecção do ZIKV em diferentes tipos celulares (ONORATI et al., 2016; BULLARD-FEIBELMAN et al., 2017; SACRAMENTO et al., 2017; MESCI et al., 2018b). O SOF é um pró-fármaco análogo de nucleotídeo usado em combinação com outras drogas no tratamento da infecção crônica do vírus da Hepatite C (HCV), membro da família Flaviviridae (ELFIKY et al., 2013; SULKOWSKI et al., 2014; GENTILE et al., 2015). Após sua conversão em ativo trifosfato, SOF age no HCV através da inibição da RNA polimerase, inibindo a replicação (SULKOWSKI et al., 2014; GENTILE et al., 2015). O gene que codifica a RNA polimerase viral é o mais conservado dentre os membros da família Flaviviridae (LAROCCA et al., 2016), sugerindo a possibilidade de um alvo e mecanismo de ação em comum.

Mais recentemente, estudos com a droga cloroquina mostraram eficácia na limitação da transmissão vertical do ZIKV em camundongos (CAO et al., 2017; LI et al., 2017; SHIRYAEV et al., 2017). A cloroquina é amplamente usada no tratamento da malária e não demonstra nenhum efeito tóxico em grávidas e crianças. Acredita-se que a cloriquina afeta a acidificação dos endosomos e portanto, obstrui a fusão do 
envelope viral com a membrana endossomal (SHIRYAEV et al., 2017). Devido ao uso seguro a longo prazo, ausência de contra-indicações a grávidas, além do baixo custo e disponibilidade universal da cloroquina, seu uso sozinho ou em combinação (como por exemplo, sofosbuvir) poderia ser considerado no tratamento e profilaxia do ZIKV.

Apesar de medidas preventivas como a erradicação do mosquito e a vacina do ZIKV serem imperativas para o controle a longo prazo desse patógeno, o estudo da infecção do ZIKV em humanos e identificação de inibidores com potencial terapêtico permanecem componentes importantes à resposta global à essa emergente ameaça, ilustrando a vantagem da reposicionamento de compostos já aprovados para uso clínico em ensaios in vitro. 


\section{OBJETIVOS}

\subsection{OBJETIVOS GERAIS}

O objetivo deste projeto consistiu em analisar in vitro os efeitos fenótipopatogênicos da infecção pelo ZIKV em células neurais derivadas de iPSC humanas e obter uma plataforma para triagem de fármacos.

\subsection{OBJETIVOS ESPECÍFICOS}

> Produzir células progenitoras neurais (NPCs), neuroesferas e neurônios a partir das células-tronco pluripotentes induzidas (iPSC) de indivíduos controles;

> Caracterizar biologica e molecularmente os diferentes tipos celulares gerados;

$>$ Infectar os diferentes tipos celulares in vitro com as cepas brasileiras e africanas de ZIKV;

> Caracterizar biologica e molecularmente as células infectadas pelo ZIKV;

> Analisar morte e replicação viral nos diferentes tipos celulares;

> Analisar o número de sinapses dos neurônios infectados, através da quantificação de puncta usando proteínas pré e pós-sinápticas;

> Testar Sofosbuvir em culturas celulares infectadas com o ZIKV; 


\section{MATERIAIS E MÉTODOS}

\subsection{LINHAGEM CELULAR}

Para realização deste projeto, 2 linhagens celulares controles foram selecionadas (PD16 e PD7). Essas linhagens celulares já foram reprogramadas em iPSC a partir de células-tronco de dente decíduo esfoliado no projeto de doutoramento da aluna Fabiele Baldino Russo (RUSSO, 2015) e fazem parte do nosso biorrepositório (CEP/ICB parecer-1001). De modo geral, a reprogramação foi feita utilizando-se o kit de vírus não-integrativo Sendai (Thermo Fisher), com os "4 fatores de Yamanaka"(Oct4, Sox2, c-Myc e Kfl4), de acordo com as recomendações do fabricante e modificações ao protocolo conforme anteriomente descrito.

\subsection{MANUTENÇÃO E EXPANSÃO DAS IPSC}

As iPSC foram cultivadas com troca diária do meio de cultura e expandidas de acordo com a necessidade para os experimentos. De modo geral, as células foram mantidas em placas tratadas com Matrigel (BD Biosciences) e meio mTeSR-1 (Stem Cell Technologies) e cultivadas em incubadora com atmosfera úmida a $37^{\circ} \mathrm{C}$ e $5 \%$ $\mathrm{CO}_{2}$ por toda a duração dos experimentos.

\subsection{PRODUÇÃO DE CORPOS EMBRIÓIDES}

No dia 5 de cultivo das iPSC, o meio foi substituído por meio N2 (DMEM/F12 suplementado com N2 1x - Thermo Fisher) e dois inibidores de SMAD, sendo $1 \mu \mathrm{M}$ de

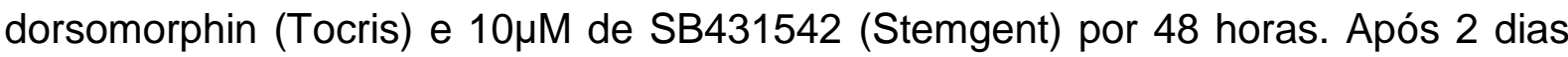
nessas condições, as colônias foram removidas da placa e cultivadas em suspensão para formação de corpos embrióides (do inglês embryoid bodies, EB) por 1 semana 
em rotação de $90 \mathrm{rpm}$ em meio $\mathrm{N} 2$, em incubadora com atmosfera úmida a $37^{\circ} \mathrm{C}$ e $5 \% \mathrm{CO}_{2}$.

\subsection{PRODUÇÃO DE ROSETAS E CÉLULAS PROGENITORAS NEURAIS (NPCS)}

Após 7 dias em cultura, os EBs foram levemente dissociados e transferidos para adesão em uma nova placa tratada com Matrigel em meio NBF (Suplementos 0,5X N2 e 0,5X ㅌ27 com adição de 20ng/mL de bEGF - Thermo Fisher). Após a adesão dos EBs à matriz, as rosetas se formaram em até cinco dias. A coleta das rosetas foi feita manualmente sob observação ao microscópio EVOs (Thermo Fisher), dissociadas enzimaticamente com Accutase (Thermo Fisher) por 7 minutos e transferidas para placas de cultivo tratadas previamente com poliornitina $(10 \mu \mathrm{g} / \mathrm{mL}-$ Sigma Aldrich) e laminina $(2,5 \mu \mathrm{g} / \mathrm{mL}$ - Thermo Fisher) , contendo o meio de cultura NBF. As NPCs foram cultivadas com troca periódicas de meio NBF e expansão enzimática com Accutase (Thermo Fisher), em incubadora com atmosfera úmida a $37^{\circ} \mathrm{C}$ e $5 \% \mathrm{CO}_{2}$.

\subsection{PRODUÇÃO DE NEUROESFERAS}

As NPCs foram cultivadas como descrito nos itens acima em placas de 100mm de diâmetro. Quando atigiram uma confluência de aproximadamente 90\%, as células foram raspadas para formar neuroesferas, cultivadas em meio NBF. As células foram dissociadas por pipetagem suave e distribuídas em poços numa placa de seis poços e mantidas em agitação constante de 90 rpm, em incubadora com atmosfera úmida a $37^{\circ} \mathrm{C}$ e $5 \% \mathrm{CO}_{2}$, por 5 a 7 dias.

\subsection{PRODUÇÃO DE NEURÔNIOS}


As NPCs foram cultivadas como descrito nos itens acima em placas de $100 \mathrm{~mm}$ de diâmetro. Ao atingirem aproximadamente $70 \%$ de confluência, o meio NBF foi

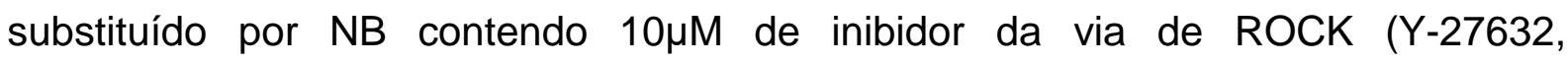
Calbiochem). As células foram mantidas nesse meio por 48 horas e então, o meio foi novamente substituído por somente meio NB. Essa condição foi mantida por 28 dias em incubadora com atmosfera úmida a $37^{\circ} \mathrm{C}$ e $5 \% \mathrm{CO}_{2}$, com trocas periódicas do meio, período considerado suficiente para a diferenciação neuronal (MARCHETTO et al., 2010).

\subsection{INFECÇÃO VIRAL IN VITRO}

Duas cepas de vírus Zika foram usadas para infecção: um isolado de um caso clínico no Brasil (ZIKVBR), fornecido pelo Instituto Evandro Chagas em Belém-PA e a linhagem africana MR-766 (ZIKVAF), uma cepa referência isolada em Uganda em 1947, fornecida pelo Instituto Pasteur em Dakar, Senegal. Os ensaios de cultura e titulação viral foram realizadas em colaboração com os grupos de pesquisa dos laboratórios do Prof. Dr. Edson Durigon e Prof. Dr. Paolo Zanotto (ICB/USP) (CUGOLA et al., 2016). As culturas celulares foram infectadas com diferentes multiplicidades de infecção (MOI 1 ou 10). Para adsorção viral, células em monocamadas foram incubadas por $1 \mathrm{~h}$ a $4^{\circ} \mathrm{C}$ com leve agitação a cada 10 minutos. Em seguida, o inóculo foi removido e as células lavadas uma vez com dPBS. O meio de cultura foi adicionado às células e os efeitos acompanhados por períodos determinados (ex. 24, 48, 72 e 96 horas pós infecção. Para controles MOCK (sobrenadante de cultura de células C6/36 não infectadas) o mesmo volume de sobrenadante foi adicionado à cada experimento, seguindo os mesmos procedimentos descritos.

\subsection{IMUNOFLUORESCÊNCIA}

Para a caracterização, células plaqueadas sobre lamínula de vidro foram lavadas com dPBS e fixadas em $4 \%$ de paraformaldeído (USB Corporation) durante 
15 minutos em temperatura ambiente. Após a fixação, as células foram lavadas 3 vezes com dPBS e permeabilizadas com 0,1\% de Triton (Promega) por 15 minutos em temperatura ambiente. Em seguida, as células foram submetidas ao bloqueio em dPBS contendo $2 \%$ de soro albumina bovino durante 4 horas a temperatura ambiente. Após o bloqueio, as células foram incubadas com anticorpos primários por 16 horas a $4^{\circ} \mathrm{C}$. Passado o período de incubação dos anticorpos primários, as células foram lavadas por três vezes com dPBS e os respectivos anticorpos secundários, Alexa Fluor 488, Alexa Fluor 555 e Alexa Fluor 647 (Thermo Fisher) foram adicionados e incubados por 1 hora em temperatura ambiente. Ao final, as células foram lavadas 3 vezes com PBS $1 x$ e DAPI $(1 \mu \mathrm{g} / \mathrm{mL})$ foi adicionado por 5 minutos em temperatura ambiente. As lâminas foram montadas utilizando ProLong Gold (Thermo Fisher). A imunorreatividade foi avaliada em microscopia de fluorescência confocal Zeiss LSM 780-NLO (CEFAP/USP). Anticorpos utilizados para a caracterização, de NPCs: Musashi1 (Abcam, 1:1000), SOX2 (Cell Signaling Technology, $1: 200)$, Nestin (Abcam, 1:100); de neurônios: MAP2 (Abcam, 1:1000), Synapsin-1(Millipore, 1:500), Homer1 (Synaptic Systems, 1:200); de astrócitos: GFAP (Abcam, 1:400); de morte celular: caspase clivada-3 (Cell Signaling, 1:400); e ZIKV; anti-flavivirus D1-4G2-4-15 (Millipore, 1:400).

\subsection{CONTAGEM DE SINAPSES COLOCALIZADAS (PUNCTA)}

Para a quantificação de sinapses, NPCs controle MOCK e infectadas com ZIKVBR (MOI 1) foram plaqueadas sobre lamínula de vidro e diferenciadas em neurônios conforme descrito anteriormente. Após 28 dias, as células foram fixadas e preparadas conforme o protocolo de imunofluorescência acima, usando os anticorpos para MAP2 (filamento neuronal), Synapsin-1 (proteína pré-sináptica) e Homer-1 (proteína pós-sináptica). A contagem de puncta foi feita visualmente através da colocalização da proteína pré-sináptica com a proteína pós-sináptica sobre o filamento neural. 


\subsection{EXTRAÇÃO DE RNA E ENSAIOS DE PCR EM TEMPO REAL (QPCR)}

O RNA total das amostras foi extraído utilizando Trizol (Thermo Fisher), de acordo com as instruções do fabricante. Os pellets foram resuspendidos em $30 \mu \mathrm{L}$ de água destilada RNase-free e quantificados usando o espectrofotometro (NanoDrop Technologies) e conservados a $-80^{\circ} \mathrm{C}$. As células foram testadas quanto a presença de receptores TAM; o cDNA foi obtido usando SuperScript III (Thermo Fisher) e submetido a qPCR utilizando sondas Taqman conforme protocolo do fabricante; para normalização, foi utilizado o ACTB como controle interno (housekeeping gene). Para detecção de ZIKV, os oligonucleotídeos específicos para ZIKV foram sintetizados com 5-FAM como repórter fluorescente (Sigma Life Science). Os oligonucleotídeos ZIKV 835, ZIKV 911c and ZIKV 860-FAM já foram descritos anteriormente (LANCIOTTI et al., 2008). As reações constaram de $10 \mu \mathrm{L}$ de amostra e $10 \mu \mathrm{L}$ de mix de reagentes do AgPath-IDTM One-Step RT-PCR (Applied Biosystems) e a amplificação consistiu do seguinte protocolo: ativação a 45ำ por 15 minutos; 95ำ por 15 minutos seguido de 40 ciclos de amplificação de $95^{\circ} \mathrm{C}$ por $15 \mathrm{~s}, 60^{\circ} \mathrm{C}$ por $15 \mathrm{~s}$, e $72^{\circ} \mathrm{C}$ por $30 \mathrm{~s}$. Para a detecção e quantificação de RNA viral, o qPCR de cada amostra foi comparado com o valor limiar de ciclo (Ct) com uma curva padrão de ZIKV em plasmídeo, que foi obtida através de diluições seriadas de um clone do gene do envelope de um isolado da epidemia na ilha Yap em 2007 (fornecido pelo Instituto Pasteur em Dakar, Senegal). $\mathrm{O}$ valor de $\mathrm{Ct}$ do controle positivo foi usado para normalizar a expressão gênica e determinar as mudanças durante os períodos de leitura. O gene RPLA27 foi usado como controle interno. As amplificações foram feitas no equipamento de PCR em tempo real Applied Biosystems 7500 e os dados analisados usando o software SDS da Applied Biosystems.

\subsection{MICROSCOPIA ELETRÔNICA DE TRANSMISSÃO}

Os pellets de células foram fixados com solução de glutaraldeído 3\% (Merck) a $4^{\circ} \mathrm{C}$ por $2 \mathrm{~h}$, lavados com três trocas de dPBS por $1 \mathrm{~h}$, e incubados por $16 \mathrm{~h}$ a $4^{\circ} \mathrm{C}$. No dia seguinte, a pós-fixação foi feita com 1\% tetróxido de ósmio por 30 minutos à 
temperatura ambiente, seguida de uma desidratação gradual com um série de concentrações de álcool: 70\%, 95\% e 100\%. O material foi lavado em duas trocas de óxido de propileno e colocado em uma mistura de 1:1 de óxido de propileno e meio de incorporação em temperatura ambiente por $1 \mathrm{~h}$ em um dispositivo de rotação seguido por $100 \%$ de meio de incorporação em temperatura ambiente por $24 \mathrm{~h}$. Meio de incorporação fresco foi mantido durante a noite a $37^{\circ} \mathrm{C}$ e polimerizado em estufa por 24h. O material foi cortado em seções ultrafinas e corado com acetato de uranilo e citrato de chumbo. As células foram visualizadas com microscópio eletrônico de transmissão (JEOL, JEM 1011, Peabody, Massachusetts, EUA).

\subsection{CITOMETRIA DE FLUXO}

As células coletadas foram submetidas ao protocolo de marcação por anexina $\mathrm{V}$ e iodedo de propídeo (PI) (BD Biosciences). As células foram lavadas duas vezes em dPBS e coletadas em $200 \mu \mathrm{L}$ de $0.25 \%$ tripsina (LGC) por 10 minutos a $37^{\circ} \mathrm{C}$. Em seguida, as células em suspensão foram lavadas em DMEM com 10\% FBS e centrifugadas por $5 \mathrm{~min}$ a $450 \mathrm{~g}$ e $4^{\circ} \mathrm{C}$. As células foram então resuspendidas com $20 \mu \mathrm{L}$ de tampão de ligação em placas de 96 poços de fundo redondo e com $1 \mathrm{LL}$ de anexina V-FITC e 1uL de PI e então incubadas em temperatura ambiente por 15 minutos, protegido da luz. Após o período de incubação, as amostras foram adicionadas à $80 \mu \mathrm{L}$ de tampão de ligação e analisadas no citômetro de fluxo BD FACS Accuri C6 (BD Biosciences).

\subsection{TRATAMENTO COM SOFOSBUVIR}

NPCs $(\mathrm{MOI}=10)$ e neurônios $(\mathrm{MOI}=1)$ foram infectados com ZlKVBR, como descrito anteriormente. Para o tratamento com o Sofosbuvir (SOF), DMSO foi adicionado no volume equivalente correspondente a maior dose de SOF usado no meio de cultura (0.1\% DMSO). NPCs e neurônios foram tratados imediatamente após a infecção e a cada 24 horas durante o toda a duração do experimento. SOF (Acme 
Bioscience AB3793) foi adicionado ao sobrenadante da cultura celular nas

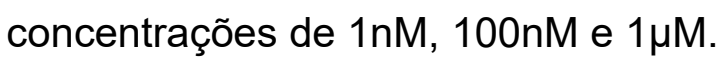




\section{$5 \quad$ RESULTADOS}

\subsection{INFECÇÃO PELO ZIKV EM CÉLULAS NEURAIS IN VITRO}

Células progenitoras neurais (NPCs), neuroesferas e neurônios de 2 indivíduos controles (PD16 e PD7) foram gerados conforme protocolos descritos anteriormente (item 4.2-4.6). Estas células já foram previamente caracterizadas em nosso laboratório (RUSSO, 2015). As infecções virais foram realizadas conforme descrito no item 4.7.

\subsubsection{NPCs}

As NPCs foram plaqueadas em placas de 24 poços na concentração de $0,5 \mathrm{x}$ $10^{5}$ células por poço. No dia seguinte ao plaqueamento, as células foram submetidas à infecção viral pelos MOCK, ZIKVBR e ZIKVAF, com MOI de 1 e 10. O experimento foi parado nos tempos de $24 \mathrm{~h}, 48 \mathrm{~h}, 72 \mathrm{~h}$ e $96 \mathrm{~h}$ e células e meio sobrenadante foram submetidos à ensaios de imunofluorescência, microscopia eletrônica de transmissão, morte celular por citometria de fluxo e detecção viral por qPCR.

As análises por imunofluorescência reveleram susceptibilidade das NPCs à infecção por ZIKV já no período de 24h pós-infecção, para ambos MOI de 1 (Figura 3) e MOI de 10 (Figura 4). Os anticorpos contra Nestina, uma proteína dos filamentos intermediáros expressa em células em divisão durante os estágios de desenvolvimento do SNC, e contra antígenos específicos de flavivírus (D1-4G2-4-15) foram usados na caracterização e identificação das NPCs e ZIKV, respectivamente. 
Figura 3 - Ensaio de imunofluorescência de NPCs MOI de 1, 24h x 96h

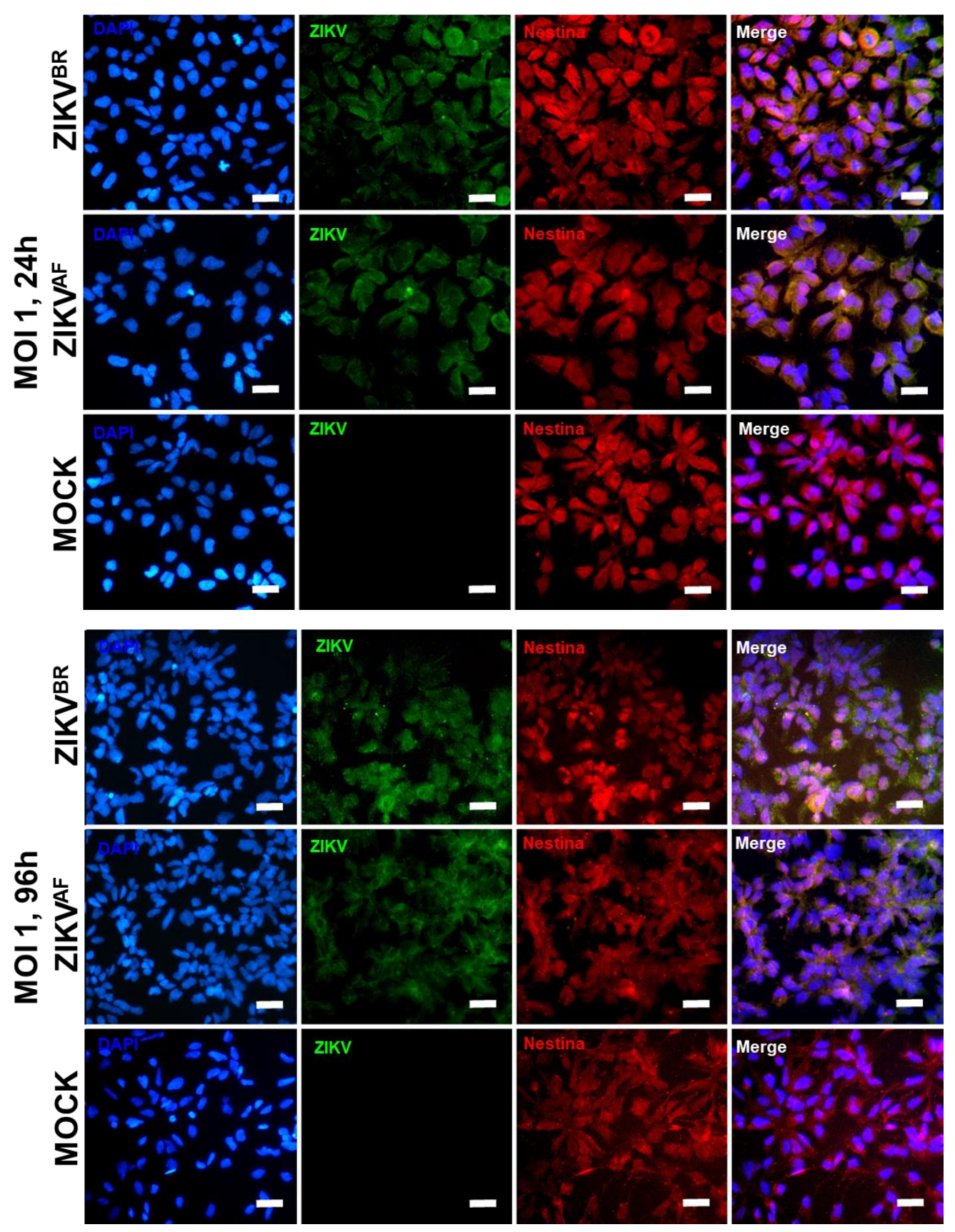

Fonte: (CUGOLA, et al., 2016, adaptado por CUGOLA, F.R., 2018).

Legenda: Análise da expressão dos marcadores Nestina e D1-4G2-4-15 por imunofluorescência em NPCs controle MOCK e infectados com ZIKVBR e ZIKVAF (MOI=10) em 24h e 96h pós-infecção. Barra de escala, $25 \mu \mathrm{m}$. 
Figura 4 - Ensaio de imunofluorescência de NPCs MOI de 10, 24h x 96h

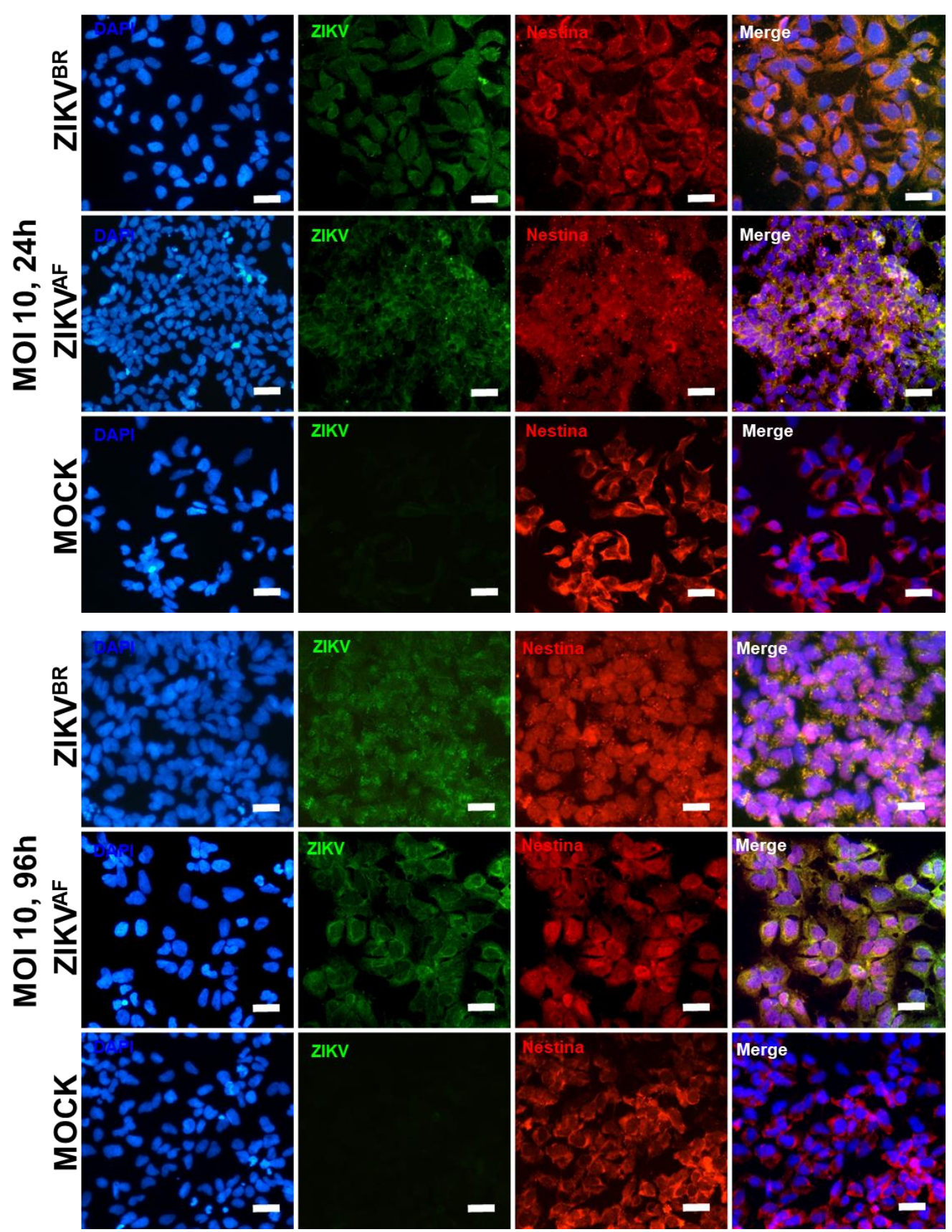

Fonte: (CUGOLA, et al., 2016, adaptado por CUGOLA, F.R., 2018).

Legenda: Análise da expressão dos marcadores Nestina e D1-4G2-4-15 por imunofluorescência em NPCs controle MOCK e infectados com ZIKVBR e ZIKVAF (MOI=10) em 24h e 96h pós-infecção. Barra de escala, $25 \mu \mathrm{m}$. 
Além disso, a análise por microscopia eletrônica de transmissão da infecção do ZIKVBR em NPCs permitiu detectar a presença de partículas virais em diversos estágios de replicação e "fábricas de vírus", 24h pós-infecção (Figura 5). O citoplasma de células infectadas aparentava normalidade na ausência das "fábricas de vírus".

Figura 5 - Microscopia eletrônica de transmissão em NPCs

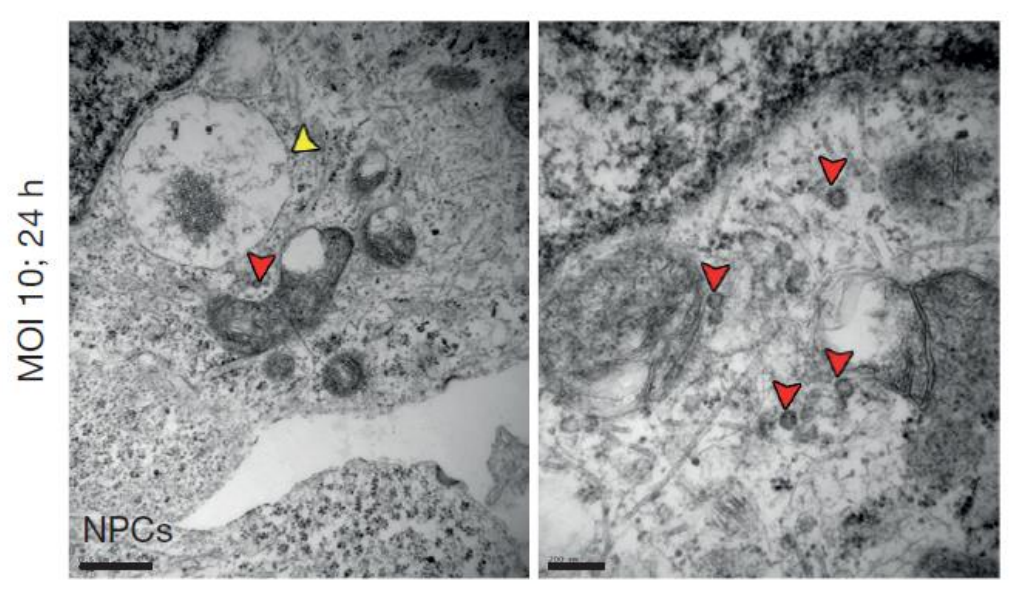

Fonte: (CUGOLA, et al., 2016)

Legenda: Imagens representativas da detecção das partículas viras de ZIKVBR (setas vermelhas) e fábrica de vírus (seta amarela) em NPCs por microscopia eletrônica de transmissão 24h pós-infecção ( $\mathrm{MOI}=10)$. Barra de escala, $0.5 \mu \mathrm{m}$ (esquerda); 200nm (direita).

O meio sobrenadante colhido em cada tempo do experimento foi submetido à detecção de partículas virais por PCR em tempo real. A quantidade de partículas de ZIKVBR nos sobrenadantes de cultura de NPCs aumentou a cada tempo, sugerindo uma produção eficiente de particulas virais infecciosas, para ambos $\mathrm{MOI}$ de 1 e 10 (Figura 6). Para ZIKVAF, a produção de partículas virais nos meios sobrenadante caracterizou-se por um leve aumento seguido de uma queda. 
Figura 6 - Dinâmica da replicação viral em NPCs ao longo do tempo
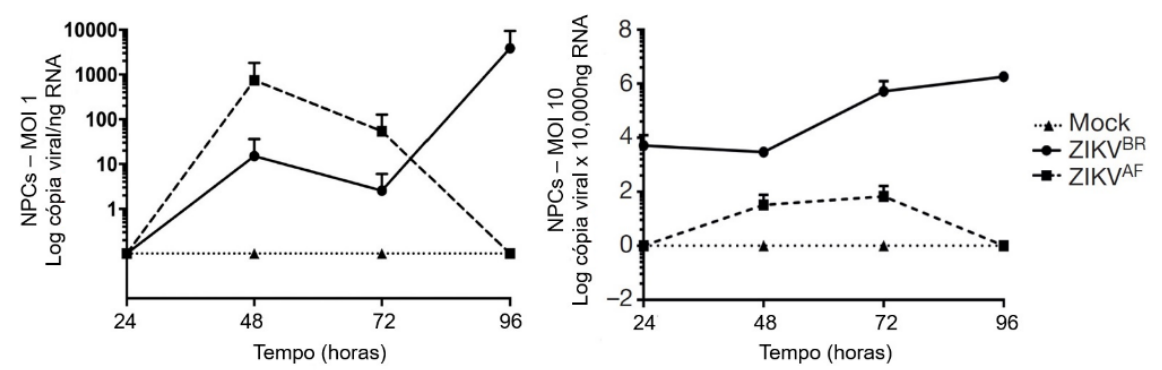

Fonte: (CUGOLA, et al., 2016, adaptado por CUGOLA, F.R., 2018).

Legenda: Dinâmica da replicação viral em NPCs ao longo do tempo para $\mathrm{MOI}=1$ (esquerda) e $\mathrm{MOI}=10$ (direita); $n=2$ réplicas técnicas de RNA de duas linhagens diferentes; barra de erro, erro padrão da média.

A análise de morte celular foi feita a cada tempo e foi possível observar um aumento no número de células apoptóticas/necróticas para as culturas infectadas com ZIKVBR e ZIKVAF quando comparadas ao controle MOCK para o $\mathrm{MOI}$ de 10, mas não para o $\mathrm{MOI}$ de 1 durante o mesmo período (Figura 7).

Figura 7 - Dinâmica de morte celular em NPCs ao longo do tempo
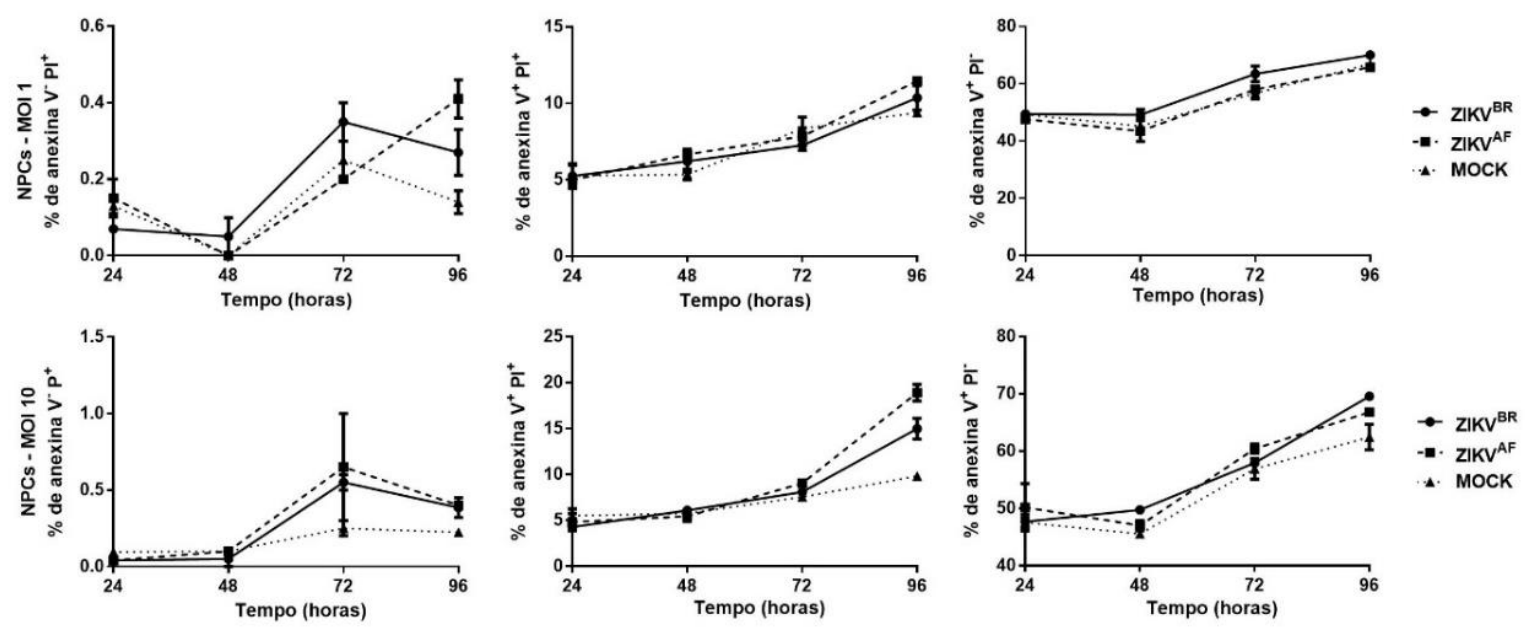

Fonte: (CUGOLA, et al., 2016, adaptado por CUGOLA, F.R., 2018).

Legenda: Dinâmica da morte celular em NPCs ( $\mathrm{MOI}=1$ e $\mathrm{MOI}=10$ ) ao longo do tempo, revelando que não há diferenças significativas entre os tipos diferentes de vírus para $\mathrm{MOI}=1 ; n=2$ réplicas técnicas de duas linhagens diferentes; barra de erro; erro padrão da média; one-way ANOVA. 
Quando comparamos a morte celular entre MOCK, ZIKVBR e ZIKVAF no MOI de 10, é possível observar um aumento significativo para ZIKVBR e ZIKVAF ao longo do tempo quando comparados ao MOCK, conforme evidenciado no tempo de 48h pósinfecção na Figura 8.

Figura 8 - Morte celular em NPCs (MOI=10) por FACS com dois tamanhos diferentes de gates de células (P1 e P2)
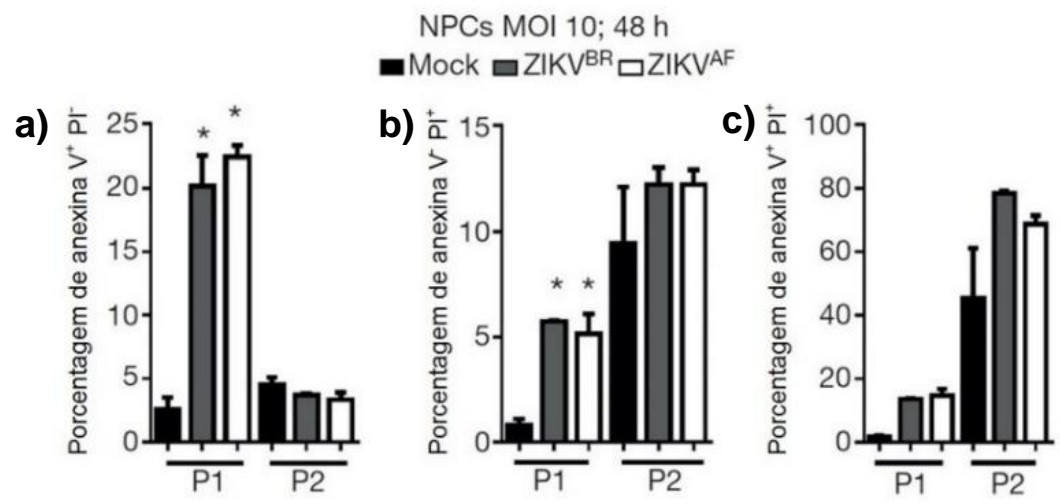

Fonte: (CUGOLA, et al., 2016, adaptado por CUGOLA, F.R., 2018).

Legenda: a) Apoptose. b) Necrose. c) Apoptose tardia. $\mathrm{MOI}=10$, 48h pós-infecção; $n=2$ réplicas técnicas de duas linhagens diferentes; barra de erro, erro padrão da média; two-way ANOVA, ${ }^{*} \mathrm{P}<0.05$. $\mathrm{Pl}$, iodeto de propídeo.

\subsubsection{Neuroesferas}

NPCs em monocamada foram infectadas com MOCK, ZIKVBR e ZIKVAF com $\mathrm{MOI}$ de 1 e 10. Após a infecção, as NPCs foram raspadas e transferidas para o cultivo em suspensão em placas de 6 poços, na concentração de $2 \times 10^{6}$ células por poço. $O$ experimento foi parado nos tempos de $24 \mathrm{~h}, 48 \mathrm{~h}, 72 \mathrm{~h}$ e $96 \mathrm{~h}$ e células e meio sobrenadante foram submetidos à ensaios de imunofluorescência, medição e detecção viral por qPCR.

De forma geral, foi possível observar que as neuroesferas controle MOCK continuaram crescendo em tamanho ao longo dos tempos de experimento, enquanto que as neuroesferas infectadas com ZIKVBR exibiram anormalidades morfológicas com aparente morte celular, especialmente no MOI de 10 (Figura 9). 
Figura 9 - Impacto da infecção do ZIKVAF e ZIKVBR em neuroesferas

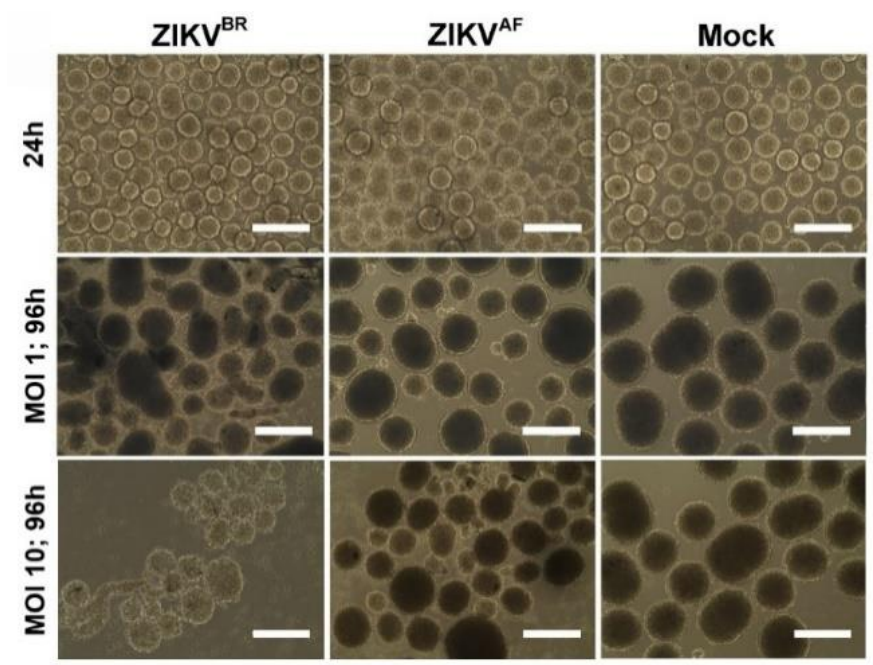

Fonte: (CUGOLA, et al., 2016, adaptado por CUGOLA, F. R., 2018)

Legenda: Imagens representativas comparando o impacto da infecção do ZIKVBR e ZIKVAF em neuroesferas $24 \mathrm{~h}$ e $96 \mathrm{~h}$ pós-infecção, MOI 1 e 10. Barra de escala, $400 \mu \mathrm{m}$.

Os tamanhos das neuroesferas infectadas com ZIKVBR eram significantemente menores do que os controles MOCK e as infectadas com ZIKVAF no tempo de 96h pós infecção. Um efeito menos dramático foi observado nas infecções usando MOI de 1, onde ambas infecções por ZIKVBR e ZIKVAF reduziram o tamanho das neuroesferas em relação ao controle MOCK (Figura 10).

Figura 10 - Alterações no diâmetro das neuroesferas ao longo do tempo

$\square$ MOCK $\square$ ZIKV $^{B R} \square$ ZIKV $^{A F}$
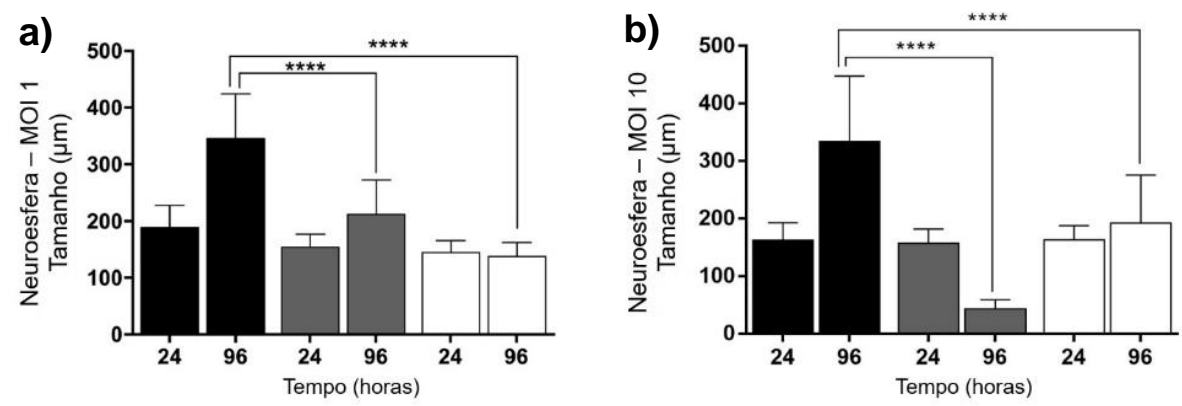

Fonte: (CUGOLA, et al., 2016, adaptado por CUGOLA, F.R., 2018).

Legenda: Alteração do diâmetro das neuroesferas infectadas com ZIKVBR e ZIKVAF em $24 \mathrm{~h}$ e 96h pós-infecção; a) $\mathrm{MOI}=1 ; n=22$ neuroesferas de duas linhagens diferentes para cada tempo; b) $\mathrm{MOI}=10 ; n=25$ neuroesferas de duas linhagens diferentes para cada tempo; barra de erro, erro padrão da média; ANOVA, ${ }^{* \star \star *} \mathrm{P}<0.0001$. 
O aumento na replicação viral foi correlacionado à redução do tamanho das neuroesferas para ambos $\mathrm{MOI}$ de 1 e 10 (Figura 11). Esses resultados sugerem que o ZIKVBR induz morte celular em NPCs, prejudicando o crescimento e a morfogênese de neuroesferas saudáveis.

Figura 11 - Dinâmica da replicação viral em neuroesferas ao longo do tempo
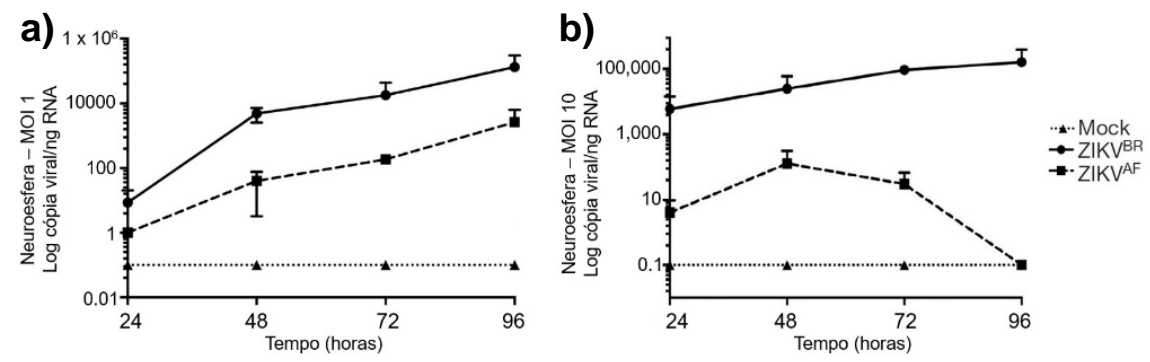

Fonte: (CUGOLA, et al., 2016, adaptado por CUGOLA, F.R., 2018).

Legenda: Dinâmica da replicação viral em neuroesferas ao longo do tempo; a) $\mathrm{MOI}=1 ; n=3$ réplicas técnicas de duas linhagens diferentes; b) $\mathrm{MOI}=10 ; n=2$ réplicas técnicas de duas linhagens diferentes; barra de erro, erro padrão da média.

Para a caracterização por imunofluorescência, após 96h pós-infecção, as neuroesferas foram retiradas de agitação e deixadas imóveis para aderirem em lamínulas de vidro de um dia para o outro. As neuroesferas aderidas marcaram positivas para antígenos específicos de flavivírus (D1-4G2-4-15) e Musashi-1, uma proteína ligante de RNA altamente expressa em células-tronco neurais e progenitoras durante o estágio embrionário, com papel na regulação da manutenção, diferenciação e destinação dessas células. As análises por imunofluorescência reveleram uma redução significativa na migração celular proliferativa para células positivas para Musashi-1 nas neuroesferas infectadas com ZIKVBR. Foi possível observar uma redução da migração para as neuroesferas infectadas com ZIKVAF em comparação ao MOCK, porém aparentemente menos afetado que nas neuroesferas infectadas com ZIKVBR (Figura 12). 
Figura 12 - Ensaio de imunofluorescência de neuroesferas

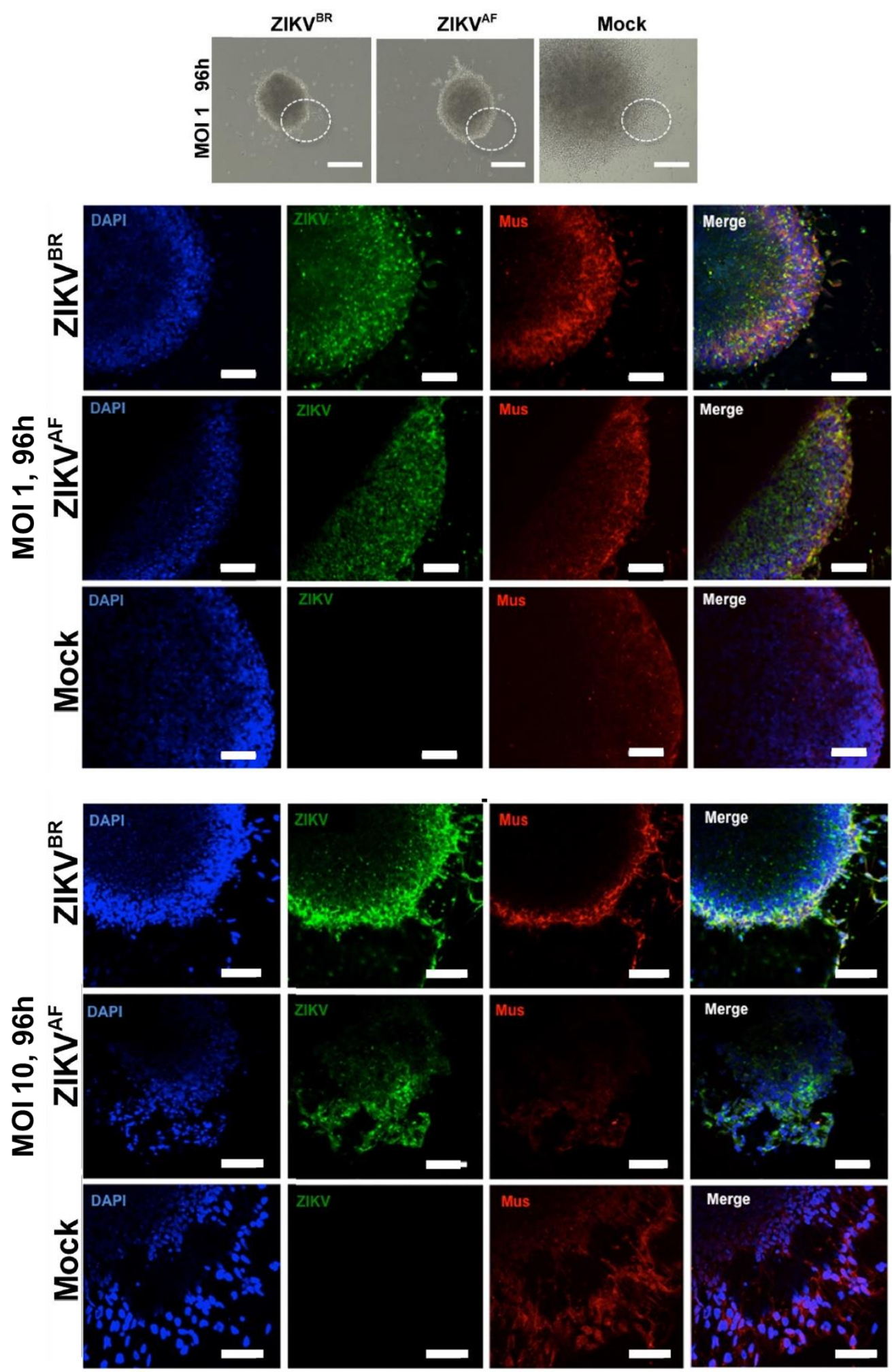

Fonte: (CUGOLA, et al., 2016, adaptado por CUGOLA, F.R., 2018)

Legenda: Imagens representativas de neuroesferas aderidas (topo). Análise da expressão dos marcadores Musashi-1 (Mus) e D1-4G2-4-15 (ZIKV) por imunofluorescência em neuroesferas, 96h pós-infecção; MOI 1 e 10; Barra de escala, $50 \mu \mathrm{m}$. 


\subsubsection{Neurônios}

Para a produção de neurônios maduros, NPCs foram plaqueadas na concentração de $1 \times 10^{5}$ células por poço, em placas de 24 poços. O meio NB recebeu $10 \mu \mathrm{M}$ de Ri durante as primeiras $48 \mathrm{~h}$, ao mesmo tempo que houve a retirada de FGFb, por todo o restante do período de cultivo, de 28 dias. $O$ aspecto das células após as quatro semanas de diferenciação foi caracterizada morfologicamente por pequenos corpos celulares, muitas projeções e ramificações, algumas bastante longas. As caracterizações molecular e eletrofisiológica desses neurônios já foram descritas anteriormente (RUSSO et al., 2018).

Após o período de diferenciação, as células foram submetidas à infecção viral pelos MOCK, ZIKVBR e ZIKVAF, com MOI de 1 e 10. O experimento foi parado nos tempos de $24 \mathrm{~h}, 48 \mathrm{~h}, 72 \mathrm{~h}$ e $96 \mathrm{~h}$ e células e meio sobrenadante foram submetidos à ensaios de imunofluorescência, microscopia eletrônica de transmissão, morte celular por citometria de fluxo e detecção viral por qPCR.

As análises por imunofluorescência reveleram susceptibilidade dos neurônios à infecção por ZIKV já no período de 24h pós-infecção, tanto em MOI de 1 (Figura 13) como MOI de 10 (Figura 14). Os anticorpos contra MAP2, uma proteína do citoesqueleto envolvida no conjunto de microtúbulos neuronais, e contra antígenos específicos de flavivírus (D1-4G2-4-15) foram usados na caracterização e identificação dos neurônios e ZIKV, respectivamente. 
Figura 13 - Ensaio de imunofluorescência de neurônio MOI de 1, 24h x 96h

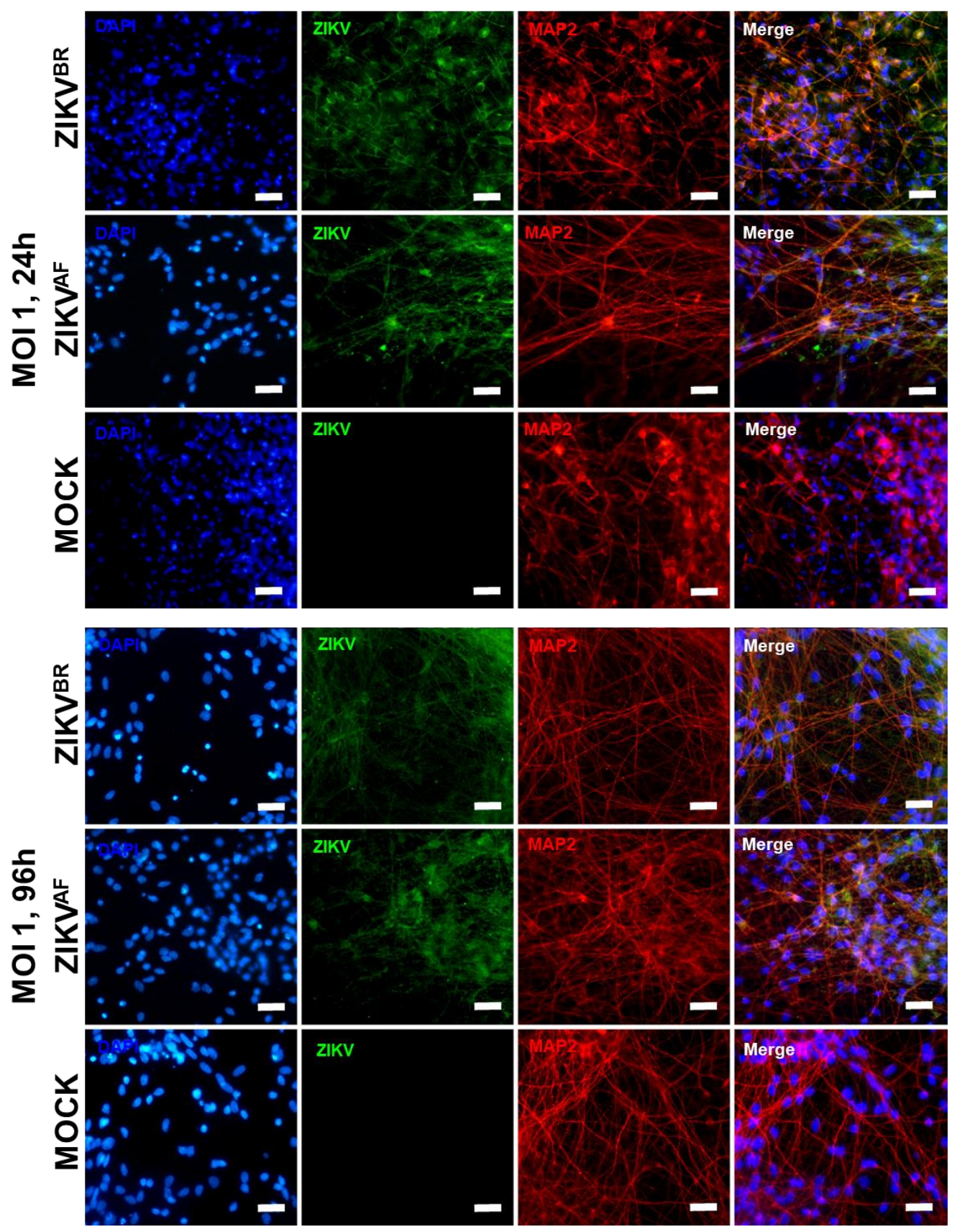

Fonte: (CUGOLA, et al., 2016, adaptado por CUGOLA, F.R., 2018).

Legenda: Análise da expressão dos marcadores MAP2 e D1-4G2-4-15 por imunofluorescência em neurônios controle MOCK e infectados com ZIKVBR e ZIKVAF (MOI=10) em 24h e 96h pós-infecção. Barra de escala, 25um. 
Figura 14 - Ensaio de imunofluorescência de neurônio MOI de 10, 24h x 96h

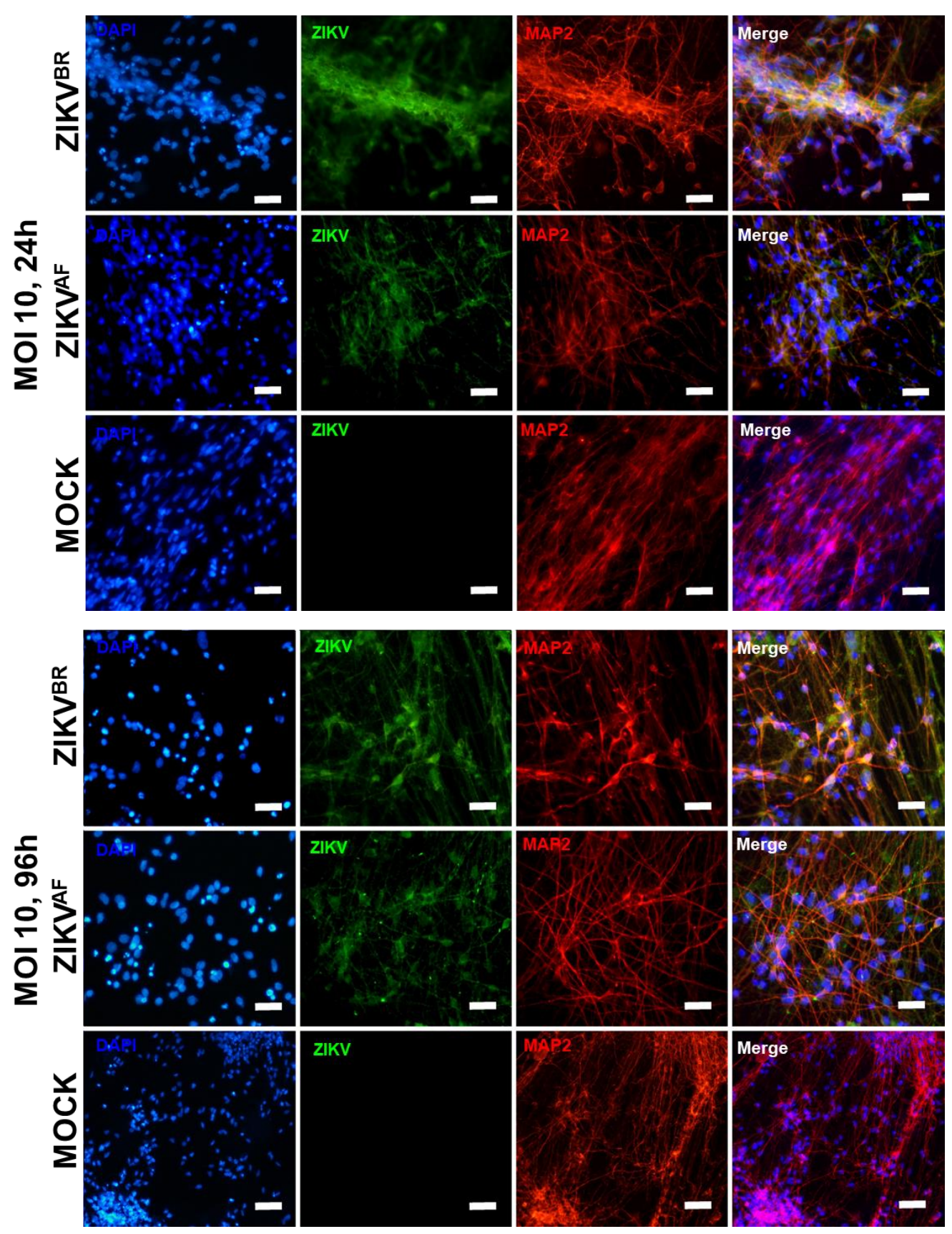

Fonte: (CUGOLA, et al., 2016, adaptado por CUGOLA, F.R., 2018).

Legenda: Análise da expressão dos marcadores MAP2 e D1-4G2-4-15 por imunofluorescência em neurônios controle MOCK e infectados com ZIKVBR e ZIKVAF (MOI=10) em 24h e 96h pós-infecção. Barra de escala, 25um. 
Além disso, a análise por microscopia eletrônica de transmissão da infecção de ZIKVBR em neurônios permitiu detectar a presença de partículas virais em diversos estágios de replicação dentro de vesículas citoplasmáticas nas células, 24h-pós infecção (Figura 15).

Figura 15 - Microscopia eletrônica de transmissão em neurônios
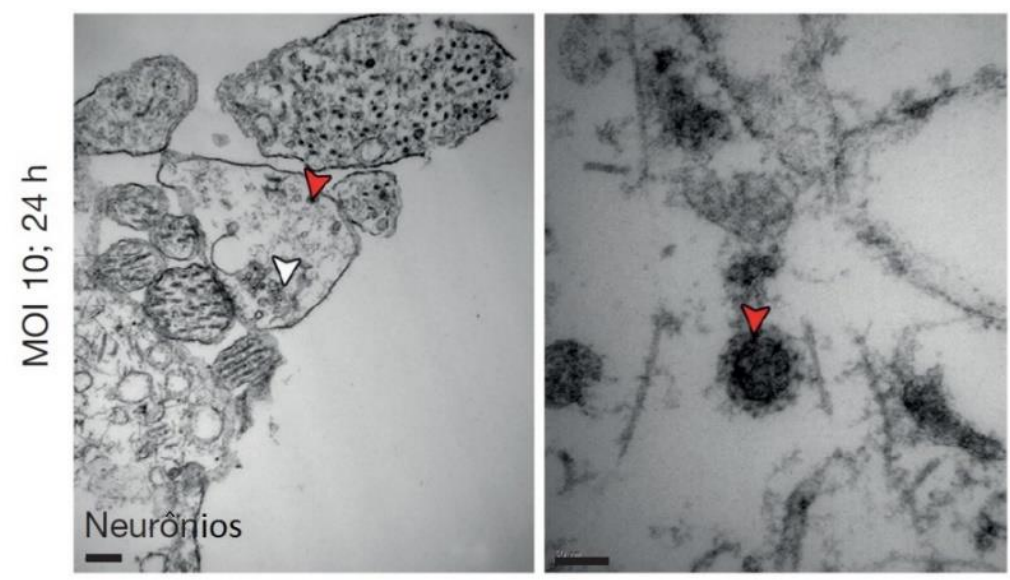

Fonte: (CUGOLA, et al., 2016, adaptado por CUGOLA, F.R., 2018).

Legenda: Detecção das partículas viras de ZIKVBR (setas vermelhas) e partículas virais imaturas (seta branca) em neurônios por microscopia eletrônica de transmissão $24 \mathrm{~h}$

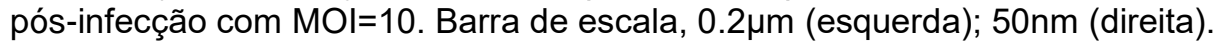

O meio sobrenadante colhido em cada tempo do experimento foi submetido à detecção de partículas virais por PCR em tempo real. Com MOI de 10, a quantidade de partículas de ZIKVBR e ZIKVAF nos sobrenadantes de cultura de neurônio aumentou a cada tempo, sugerindo uma produção eficiente de partículas virais infecciosas (Figura 16). Esse aumento gradual da replicação viral foi observado somente até as $72 \mathrm{~h}$ pós infecção nas culturas infectadas com MOI de 1. No último tempo analisado, 96h pós infecção, não houve aumento em relação ao MOCK. 
Figura 16 - Dinâmica de replicação viral em neurônios
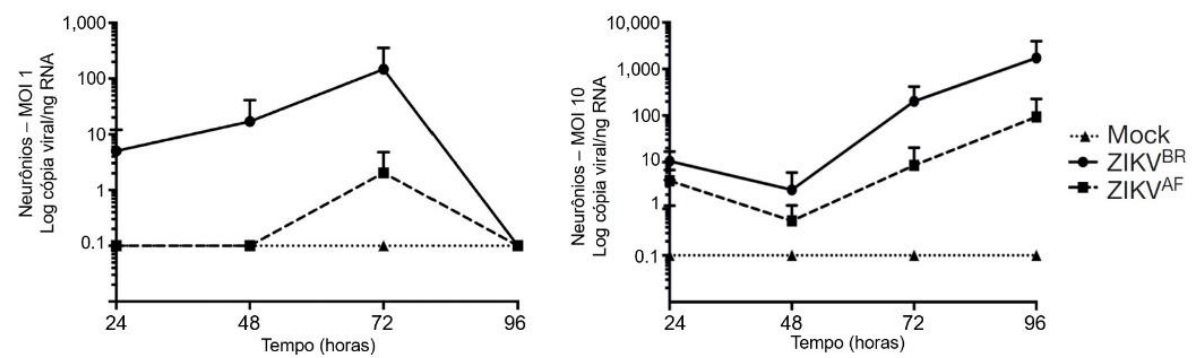

Fonte: (CUGOLA, et al., 2016, adaptado por CUGOLA, F.R., 2018).

Legenda: Dinâmica da replicação viral em neurônios ao longo do tempo para $\mathrm{MOI}=1$ (esquerda) e $\mathrm{MOI}=10$ (direita); $n=2$ réplicas técnicas de RNA de duas linhagens diferentes; barra de erro, erro padrão da média.

Análises de morte celular foram feitas a cada tempo e não foi observado nenhuma diferença significativa entre ZIKVBR e ZIKVAF para ambos MOI de 1 e 10 (Figura 17).

Figura 17 - Dinâmica de morte celular em neurônios
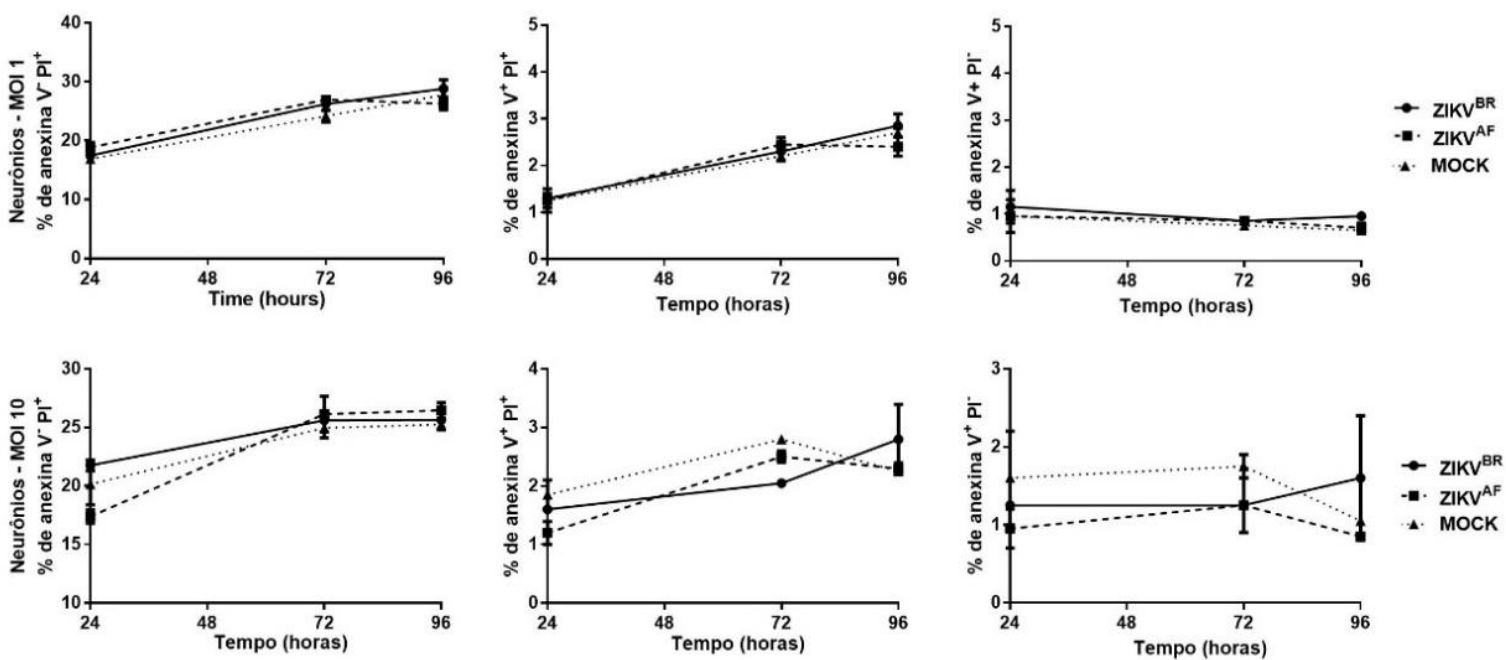

Fonte: (CUGOLA, et al., 2016, adaptado por CUGOLA, F.R., 2018).

Legenda: Dinâmica da morte celular em neurônios ao longo do tempo; $n=2$ réplicas técnicas de duas linhagens diferentes; barra de erro, erro padrão da média; one-way ANOVA. 


\subsubsection{Receptores TAM}

Os níveis de expressão dos receptores tirosina kinase TYRO3, AXL e MERKT foram determinados para NPCs e neurônios. Foi observado que as NPCs controle MOCK expressavam níveis mais altos de AXL quando comparados a neurônios controle MOCK (Figura 18A). Entretando, não houve nenhuma mudança significativa nos níveis de expressão entre as NPCs controle MOCK e as infectadas por ZIKVAF e ZIKVBR com MOI de 10 (Figura 18B).

Figura 18 - Expressão relativa dos receptores TAM
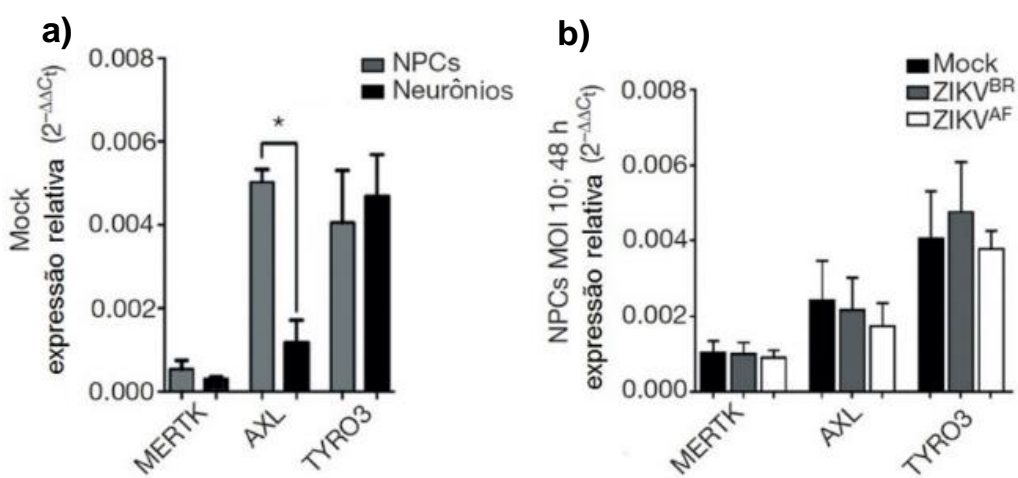

Fonte: (CUGOLA, et al., 2016, adaptado por CUGOLA, F.R., 2018).

Legenda: Expressão relativa dos receptores TAM; a) expressão dos receptores TAM em NPCs e neurônios controles MOCK; b) expressão dos receptores TAM em NPCs infectadas com ZIKVBR e ZIKVAF (MOI=10) 48h pós-infecção; $n=2$ réplicas técnicas de duas linhagens diferentes; barra de erro, erro padrão da média; $t$-test; ${ }^{* \star} P<0.01$.

\subsection{ANÁLISE DA SINAPTOGÊNESE}

Para a produção de neurônios maduros, NPCs foram plaqueadas na concentração de $1 \times 10^{5}$ células por poço em placas de 24 poços. No dia seguinte, as células foram submetidas à infecção viral pelos controle MOCK e ZIKVBR, com MOI de 1 . O meio NB recebeu $10 \mu \mathrm{M}$ de Ri durante as primeiras $48 \mathrm{~h}$, ao mesmo tempo que houve a retirada de FGFb, por todo o restante do período de cultivo, de 28 dias. 
Após o período de diferenciação, o experimento foi parado e células e meio sobrenadante foram submetidos à ensaios de imunofluorescência e qPCR para deteçcão viral.

O meio sobrenadante foi colhido ao final do experimento e submetido à detecção de partículas virais por PCR em tempo real. Após 28 dias de diferenciação, com trocas regulares do meio de cultura, foi possível detectar partículas virais no meio sobrenadante das culturas infectadas com ZIKVBR, mostrando amplificação apenas em células infectadas (Figura 19).

Figura 19 - Detecção do ZIKV por qPCR

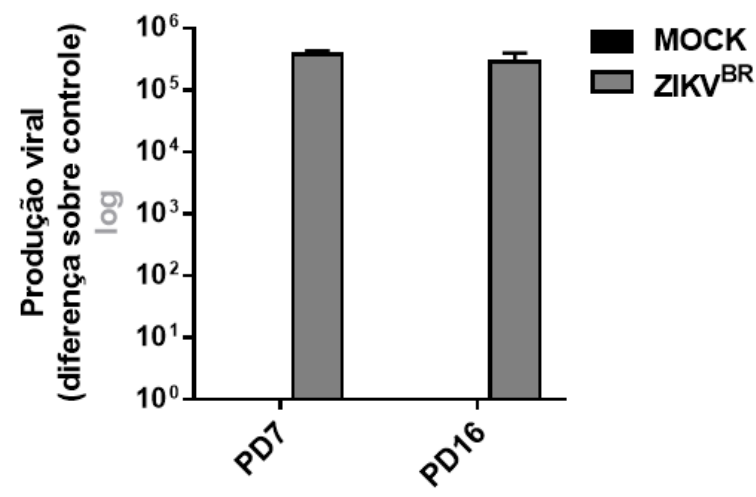

Fonte: (CUGOLA, F.R., 2018).

Legenda: Análise por qPCR para detecção de RNA viral do ZIKV em sobrenadante de neurônios infectados com MOCK e ZIKVBR após período de diferenciação. A produção viral foi normalizada em relação aos controles.

As culturas de células foram submetidas à ensaios de imunofluorescência para análise da expressão de marcador de morte celular por caspase clivada-3 (CC3). As médias de células apoptóticas foram calculadas pela média da intensidade da marcação de células CC3+ sobre a quantidade total de DAPI (Figura 20). 
Figura 20 - Marcação de morte por Caspase Clivada-3

a)

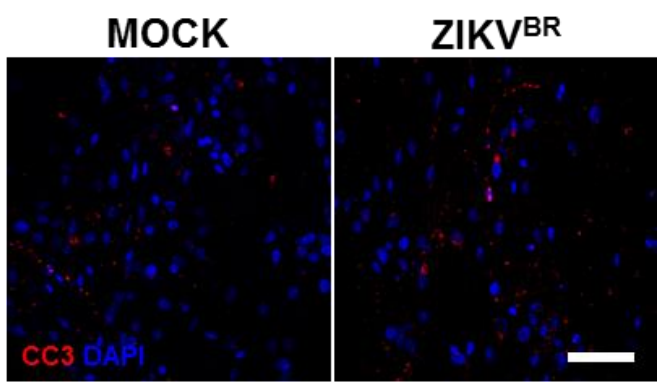

b)

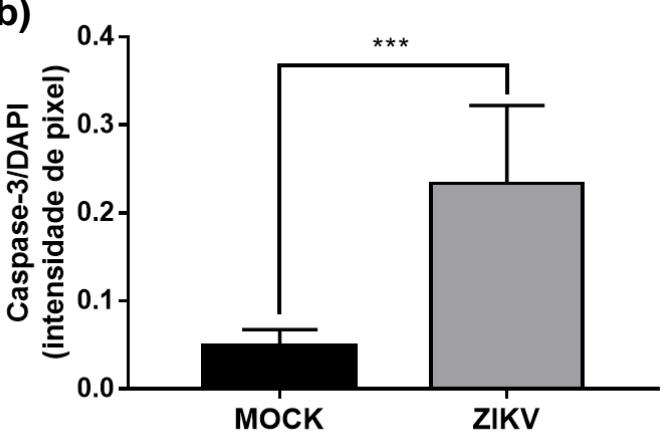

Fonte: (CUGOLA, F.R., 2018).

Legenda: a) Imagens representativas de CC3 e DAPI para neurônios controle MOCK (esquerda) e infectados com ZIKVBR (direita), barra de escala $400 \mu \mathrm{m}$; b) Comparação da quantificação de CC3 por intesidade de pixel; $n=2$ réplicas técnicas de duas linhagens diferentes; barra de erro, erro padrão da média; $t$-test, ${ }^{* * *} \mathrm{P}<0.05$.

A contagem de puncta foi realizada como a co-localização da proteína présináptica (Synapsina1) com a proteína pós-sináptica (Homer1) sobre o filamento neural (MAP2), normalizado pela quantidade de núcleos (DAPI). A média da contagem de puncta foi estatisticamente menor nos neurônios infectados pelo ZIKVBR (Figura 21).

Figura 21 - Análise da sinaptogênese

a)

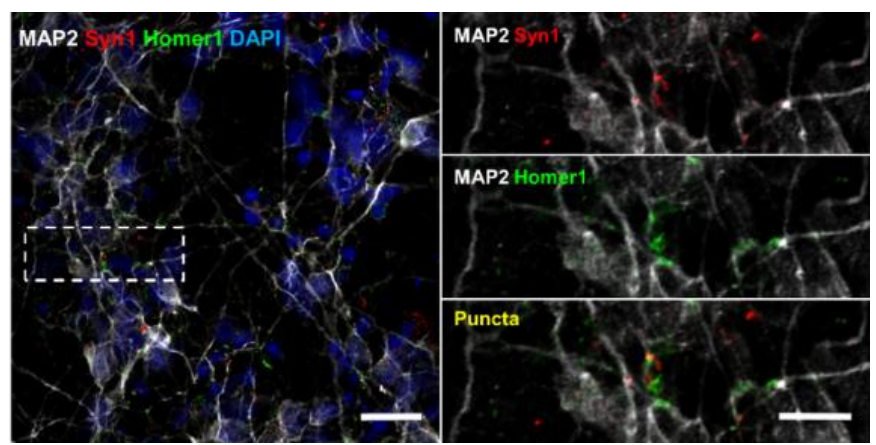

b)

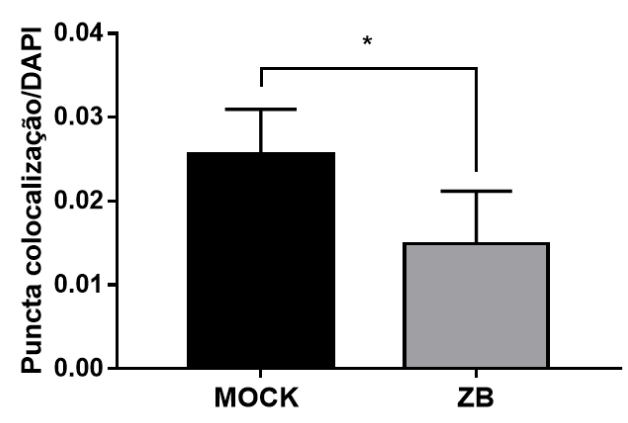

Fonte: (CUGOLA, F.R., 2018).

Legenda: a) Imagem representativa destacando proteínas pré-sináptica (Syn1) e pós-sináptica (Homer1), e a co-localização de ambas (Puncta) sobre o filamento neural (MAP2). Barra de escala, 10 $\mu \mathrm{m}$ (esquerda) e $5 \mu \mathrm{m}$ (direita). b) Representação em gráfico de barras \pm erro padrão da média da contagem de puncta; $n=5$ réplicas técnicas de duas linhagens diferentes; barra de erro, erro padrão da média; $t$-test, ${ }^{*} P<0.05$. 
Adicionalmente, analisamos as quantidades de proteínas pré-sinápticas (Synapsina1) e pós-sinápticas (Homer1). Resultados indicam que a quantidade de pontos por filamento de $100 \mu \mathrm{M}$ (MAP2) não varia entre nossos neurônios controles e infectados por ZIKVBR (Figura 22).

Figura 22 - Análise da proteínas sinápticas

a)

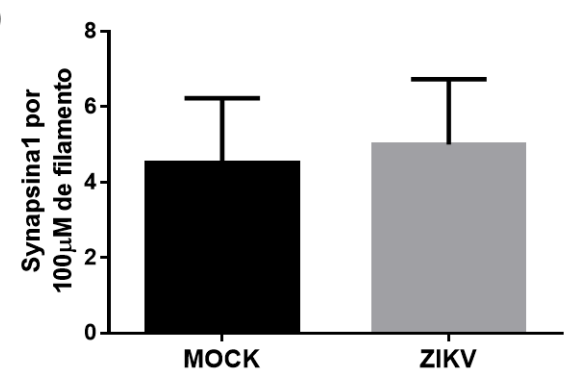

b)

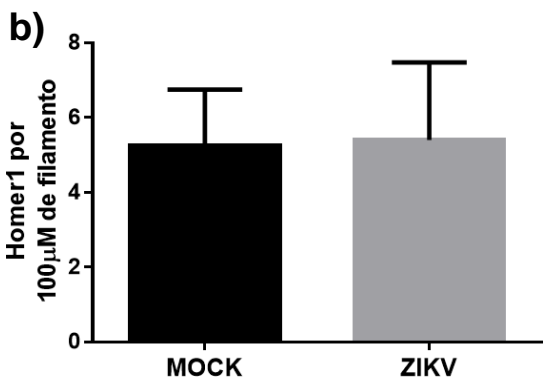

c)

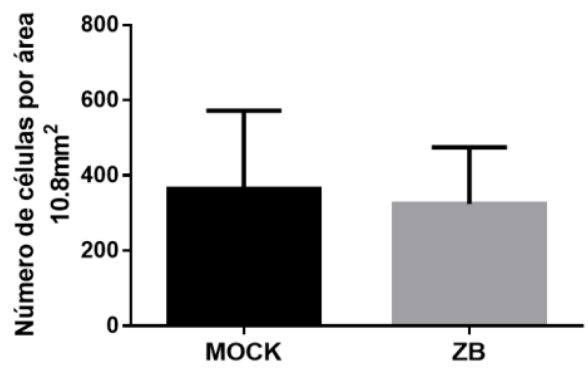

Fonte: (CUGOLA, F.R., 2018).

Legenda: Contagem dos botões sinápticos para os marcadores pré-sinápticos por $100 \mu \mathrm{M}$ de filamento de MAP2; pré-sináptico (a) e pós-sináptico (b); número total de células (c); $n=5$ réplicas técnicas de duas linhagens diferentes; barra de erro, erro padrão da média; $t$-test, ${ }^{* *} \mathrm{P}<0.05$;

\subsection{TRATAMENTO COM SOFOSBUVIR}

A fim de se avaliar o potencial de proteção celular da droga Sofosbuvir (SOF) contra a infecção do ZIKVBR, NPCs e neurônios foram infectados com ZIKVBR em MOI de 10 e SOF foi adicionado nas concentrações de 1nm, 100nm e $1 \mu \mathrm{M}$ imediatamente após o período de infecção e a cada $24 \mathrm{~h}$ durante a duração do experimento. $\mathrm{O}$ experimento foi parado no tempo de 96h pós infecção e células foram submetidas à ensaios de imunofluorescência para análise da expressão de marcador de morte celular por caspase clivada-3 (CC3) (Figura 23). 
Figura 23 - Marcação de morte por Caspase Clivada-3 em NPCs e neurônios

NPC MOI 10, $96 h$

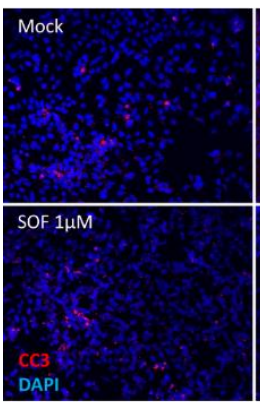

\section{zivi}

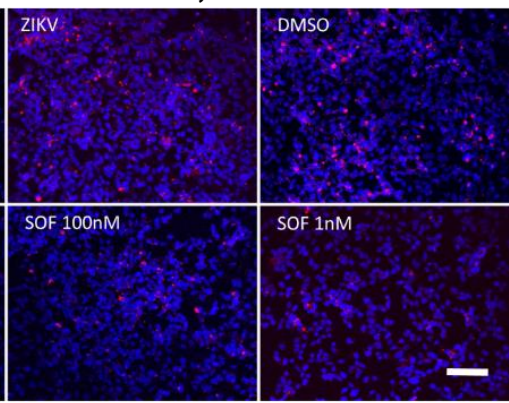

Neurônio MOI 10, 96h
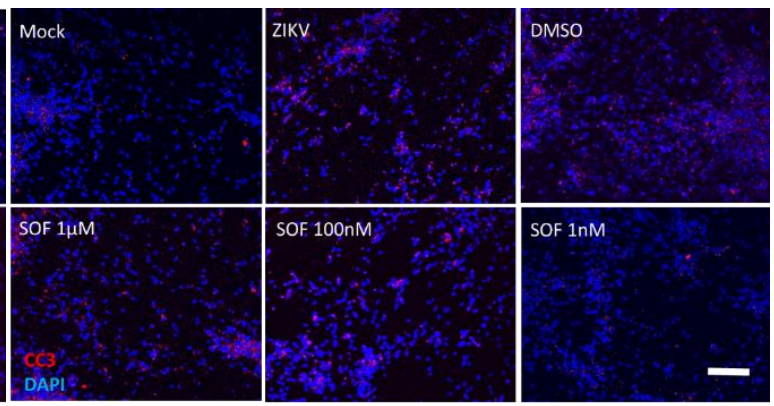

Fonte: (CUGOLA, F.R., 2018).

Legenda: Imagens representativas de Caspase Clivada-3 (CC3), um marcador de apoptose celular precoce e DAPI em NPCs e neurônios. Barra de escala, $50 \mu \mathrm{m}$.

As porcentagens de células apoptóticas foram calculadas $96 \mathrm{~h}$ pós-infecção com ZIKVBR pela média da intensidade da marcação de células CC3+ sobre a quantidade total de DAPI (Figura 24). O tratamento com Sofosbuvir reduziu a morte celular decorrente da infecção do ZIKV em NPCs e neurônios, esse último tendo respondido de forma dose-dependente.

Figura 24 - Morte por caspase clivada-3 em NPCs e neurônios tratados com SOF
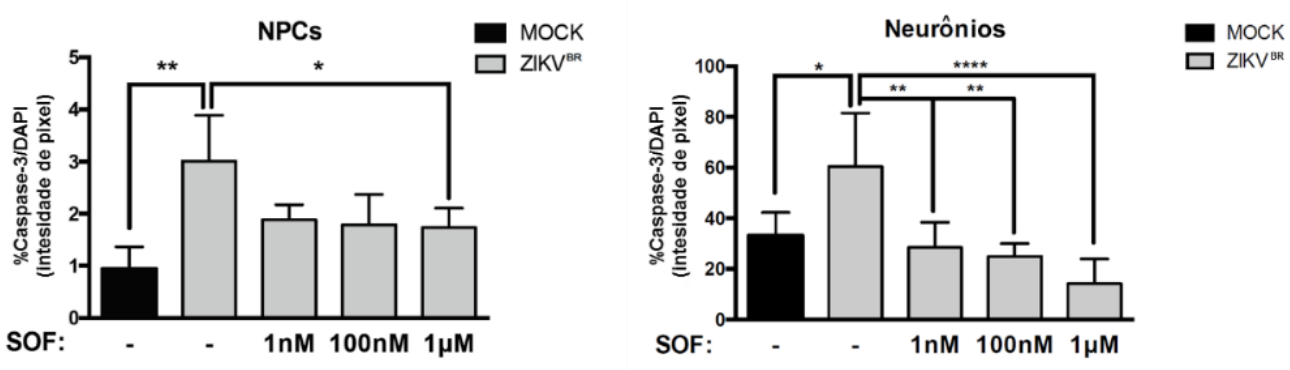

Fonte: (MESCI, et al., 2018, adaptado por CUGOLA, F.R., 2018).

Legenda: Porcentagens de células apoptóticas 96h pós-infecção com ZIKVBR, \pm desvio padrão; NPCs (esquerda), neurônios (direita); $n=2$ réplicas técnicas de duas linhagens diferentes; one-way ANOVA seguido de análise de Turkey com comparações múltiplas; ${ }^{*} \mathrm{P}<0.05,{ }^{* *} \mathrm{P}<0.01,{ }^{* * * *} \mathrm{P}<0.0001$. 
A microcefalia é talvez a característica mais marcante das consequências reportadas em recém-nascidos infectados pelo ZIKVBR (BRASIL et al., 2016a, 2016b; DE FATIMA VASCO ARAGAO et al., 2016). Nesse trabalho, usamos uma linhagem de ZIKVBR isolado de um caso febril no estado da Paraíba em 2015 para avaliar a relação causal entre ZIKVBR e as malformações cerebrais durante 0 neurodesenvolvimento. Nós avaliamos o impacto da infecção do ZIKV ${ }^{B R}$ em células neurais humanas derivadas de iPSC para estabelcer uma correlação entre o ZIKV e danos à neurogênese. Células progenitoras neurais e neurônios corticais foram gerados a partir de iPSC de dois indivíduos saudáveis. Nosso grupo tem extensa experiência em derivar células neurais a partir de iPSC para modelagem de doenças do neurodesenvolvimento (MARCHETTO et al., 2010, 2016; GRIESI-OLIVEIRA et al., 2015; CHAILANGKARN et al., 2016; VESSONI et al., 2016; RUSSO et al., 2018) e obtivemos sucesso na geração de NPCs e neurônios a partir de protocolos já estabelecidos previamente.

Os primeiros estudos investigando a infecção do ZIKV foram feitos usando a linhagem africana do vírus, a cepa MR-766 ZIKVAF, que compartilha $87-90 \%$ de similiaridade na sequência com as cepas circulantes na Polinésia e no Brasil (FAYE et al., 2014; FARIA et al., 2016). Esses estudos revelaram a habilidade do vírus de infectar células epiteliais humanas (HAMEL et al., 2015) e células progenitoras neurais derivadas de células-tronco pluripotente humanas (iPSC) in vitro, levando a uma atenuação no crescimento e a um aumento da morte celular nos modelos aplicados (CUGOLA et al., 2016; GARCEZ et al., 2016; TANG et al., 2016). Entretanto, como historicamente o ZIKVAF não foi associado a malformações congênitas, é fundamental que modelos de infecção viral sejam desenvolvidos usando-se isolados das localidades afetadas com casos de microcefalia associados à infecção com ZIKV.

A análise por microscopia eletrônica da infecção do ZIKVBR em NPCs e neurônios revelou diversas células com inclusões citoplasmáticas ou "fábricas de vírus", similar ao observado em células neuronais e gliais murinas em outro estudo (BELL; FIELD; NARANG, 1971). Partículas de núcleo denso foram identificadas dentro das "fábricas", e mediam em torno de 40nm, aparência típica de grupo de arbovírus (ROMERO-BREY; BARTENSCHLAGER, 2014; KOSTYUCHENKO et al., 
2016). Estes aspectos estão em conformidade com outros estudos morfológicos de replicação do ZIKV em modelos celulares parecidos ao nosso (CUGOLA et al., 2016; GARCEZ et al., 2016). A detecção da proteína de envelope do ZIKV em culturas celulares também foi feita pela técnica de imunocitoquímica por fluorescência, indicando a presença de infecção (CUGOLA et al., 2016; GARCEZ et al., 2016; TANG et al., 2016). Em nossas culturas, a detecção por imunofluorescência de agregados de proteínas virais nas NPCs, neuroesferas e neurônios foi confirmada para ambos MOI de 1 e 10, caracterizando o padrão de "fábrica de vírus" de flavivírus (ROMEROBREY; BARTENSCHLAGER, 2014).

O ZIKV e o vírus da dengue apresentam sintomas clínicos semelhantes e podem gerar reatividade cruzada sorológica (LANCIOTTI et al., 2008). Com isso, a técnica de qPCR tem sido empregada na identificação e quantificação das infecções por flavivírus (WANG et al., 2000; SHI et al., 2001; LANCIOTTI et al., 2008) e em nosso estudo, adotamos as sequências desenvolvidas por Lanciotti et al. para a detecção do ZIKV em sobrenadantes de cultura. Foi possível observar que para MOI de 10, a quantidade de ZIKV nos sobrenadantes de culturas de NPCs, neuroesferas e neurônios continuou aumentando com o tempo. Já para o $\mathrm{MOI}$ de 1 , somente as culturas infectadas de NPCs e neuroesferas continuaram produzindo RNA de ZIKV nos sobrenadantes, indicando uma maior susceptibilidade das NPCs à infecção viral.

Essa susceptibilidade das NPCs à infecção viral pode ser atribuída à maior expressão dos receptores tirosina qinase da família TAM, em especial o $A X L$ (NOWAKOWSKI et al., 2016). A análise dos níveis de expressão dos receptores TYRO3, AXL e MERTK em NPCs e neurônios revelou que as NPCs expressavam níveis mais altos de $A X L$ em relação aos neurônios em nossos modelos. $O A X L$ já foi identificado como um fator de entrada para o vírus da dengue (MEERTENS et al., 2012) e já foi demonstrado que o AXL é crucial para a infecção do ZIKV em astrócitos e micróglias humanas (MEERTENS et al., 2017; CHEN et al., 2018; MESCl et al., 2018a) e anticorpos neutralizantes ou pequenos RNA de interferência visando o AXL reduziram drasticamente a infecção do ZIKV em fibroblastos de derme primário (HAMEL et al., 2015). Contudo, a inibição do AXL não impediu a infecção pelo ZIKV em NPCs (WELLS et al., 2016) ou em camundongos (HASTINGS et al., 2017). Dado que NPCs co-expressam AXL e TYRO3 (CUGOLA et al., 2016; ONORATI et al., 2016) em humanos, e a superexpressão do último tornou células HEK293, normalmente 
resistentes, susceptíveis a infecção pelo ZIKV (HAMEL et al., 2015), sugerindo que o ZIKV pode estar usando diferentes fatores de ligação para entrar nas células.

Estudos demonstram um aumento no níveis de morte celular, principalmente por ativação de capase 3 e apoptose, nos dias pós-infecção com ZIKV em NPCs in vitro, modelos animais e amostras clínicas de fetos infectados com ZIKV (DANG et al., 2016; GARCEZ et al., 2016; LI et al., 2016; ONORATI et al., 2016; QIAN et al., 2016; TANG et al., 2016; ZHANG et al., 2016; HASTINGS et al., 2017). Em nosso estudo, as culturas celulares de NPCs e neurônios foram submetidas à citometria de fluxo para quantificar morte celular durante os tempos de análise após infeccção. Em culturas de NPCs infectadas, foi possível observar um aumento no número de células apoptóticas e necróticas para ambos os vírus ZIKVBR e ZIKVAF em MOI de 10 após 96h, quando comparadas ao controle MOCK. A redução no crescimento da população de células é devido parcialmente ao aumento da morte celular e desregulação do ciclo celular (TANG et al., 2016). Adicionalmente, em nosso estudo, não foi observado nenhuma diferença em morte celular neuronal entre as duas cepas de vírus nos MOI de 1 e 10.

Para a geração de neuroesferas, NPCs foram cultivadas em suspensão. Este sistema 3D foi infectado com ZIKVBR e ZIKVAF. Durante todo o período de cultivo, as neuroesferas controle MOCK apresentaram um crescimento contínuo, observação especialmente contrastante com as neuroesferas infectadas com ZIKVBR com MOI de 10, que exibiram anormalidades morfológicas evidentes e sinais de morte celular. $\mathrm{O}$ tamanho das neuroesferas infectadas com ZIKVBR era significantemente menor do que o controle MOCK e ZIKVAF, 96h pós infecção. Um efeito menos dramático foi observado com MOI de 1, onde as infecções com os ZIKVBR e ZIKVAF reduziram o tamanho das neuroesferas em comparação aos controles MOCK, evidenciando a depleção na população celular causada pela infecção (DANG et al., 2016; GARCEZ et al., 2016). Além do mais, houve um aumento na replicação do ZIKV no sobrenadante de cultura para para ambos MOI de 1 e 10. Quando as neuroesferas foram aderidas, a infecção pelo ZIKVBR e ZIKVAF evidenciou um defeito de migração nessas células. O genoma do ZIKV interage com a proteína ligante de RNA Musashi1, altamente expressa em células tronco neurais, promovendo a replicação viral e impedindo que essa proteína atinga seus alvos endógenos, desregulando fatores implicados na função de células tronco neurais (CHAVALI et al., 2017). Estes resultados sugerem que o $\mathrm{ZIKV}^{B R}$ induz a morte celular em NPCs, prejudicando o 
crescimento e morfogênese de neuroesferas saudáveis (CUGOLA et al., 2016; GARCEZ et al., 2016). Investigações usando organóides humanos infectados com ZIKV apresentaram uma redução significativa na espessura da camada cortical, semelhante à microcefalia, assim como na zona ventricular em comparação aos controles, reforçando a predileção do ZIKV por células progenitoras neurais (CUGOLA et al., 2016; QIAN et al., 2016; GABRIEL et al., 2017)

A análise de puncta sináptica tem sido regularmente empregada no estudo de patologias associadas ao neurodesenvolvimento e neurodegenerativas (MARCHETTO et al., 2010; LIU et al., 2012; VESSONI et al., 2016; TORRES; VALLEJO; INESTROSA, 2017; RUSSO et al., 2018), sugerindo que a redução da densidade de sinapses pode ser um aspecto geral em neurônios pouco desenvolvidos ou disfuncionais (ZOGHBI, 2003). Em nossos estudos, a investigação da densidade de puncta sináptica em neurônios diferenciados a partir de NPCs infectadas com ZIKVBR em ensaios de quantificação por imunofluorescência, indicou uma diminuição das sinapses em relação aos nossos neurônios controles MOCK, mas sem aparente redução da quantidade de proteínas pré e pós sinápticas presentes nas culturas. Isso sugere um defeito na formação sináptica nos neurônios infectados com ZIKVBR e pertubações na fisiologia sináptica podem produzir circuitos neurais aberrantes, disfunção sináptica e finalmente, o desenvolvimento de uma doença neurológica (ZOGHBI, 2003). Adicionalmente, análises proteômicas nessas células revelaram uma desregulação em proteínas associadas com montagem do complexo precursor pré-sináptico e proteínas de liberação de neurotransmissores, como VAMP2 e complexina 2, além de componentes da zona ativa pré-sináptica, como Piccolo, Bassoon e as proteínas SNARE sintaxina e SNAP-25ํ․ A transmissão sináptica entre neurônios requer um controle preciso das vesículas sinápticas e apesar de os componentes moleculares individuais no terminal pré-sináptico já serem bem conhecidos, seus mecanismos continuam não esclarecidos (IMIG et al., 2014; RIBEIRO; VERPOORT; DE WIT, 2018). O complexo de proteínas SNAREcomplexina-sinaptotagmina está diretamente envolvido no processo de exocitose das vesículas sinápticas (ZHOU et al., 2017) e as proteínas Piccolo e Bassoon participam

1 ROSA, et al. Host-dependent pathogenesis in human neural stem cells and neuron upon ZIKV infection. Submetido, 2018. 
de diversos processos celulares de função sináptica, regulando a estabilidade de proteínas da zona ativa pré-sináptica (GUNDELFINGER; REISSNER; GARNER, 2015), indicando que uma desregulação nessas proteínas poderia comprometer a estrutura e o funcionamento das sinapses. Além do mais, as proteínas caderina 13 e neurexina também encontravam-se desreguladas ${ }^{1}$. Uma redução na densidade de sinapses foi observada para estudos aplicando RNA de interferência para caderina 13 in vitro (PARADIS et al., 2007) e a neuroxina parece ter participação indireta na redução dos componentes da citomatriz da zona ativa, o que prejudicaria a formação e ancoragem das vesículas sinápticas (QUINN et al., 2017). A desregulação de proteínas sinápticas já foi implicada em diversas doenças neurológicas, em especial no autismo (TORRES; VALLEJO; INESTROSA, 2017), o que poderia estar contribuindo para o atraso no desenvolvimento cognitivo e problemas motores associados com o SCZ.

Diante da relação causal entre a infecção materna e a microcefalia neonatal decorrente da transmissão vertical do ZIKV, o desenvolvimento de tratamentos que diminuam a replicação viral em mulheres grávidas é de grande relevância. A droga sofosbuvir, usada no tratamento do HCV, é rotulada pelo FDA como categoria B na gravidez, o que significa que apesar de não terem sido feitos estudos controle em mulheres grávidas recebendo a droga, estudos em modelos animais não demonstraram riscos aos fetos (TOUSSAINT-MILLER; ANDRES, 2015). Em nossos estudos, o tratamento com SOF foi capaz de inibir a replicação viral em NPCs e reduziu a morte celular decorrente da infecção do ZIKV em NPCs e neurônios (MESCI et al., 2018b) como demonstrado também por outros grupos (BARROWS et al., 2016; BULLARD-FEIBELMAN et al., 2017; SACRAMENTO et al., 2017; MESCl et al., 2018a). Em estudos in vivo, o tratamento com SOF foi capaz de reduzir a carga viral em camundongos, sendo que o tratamento foi bem tolerado e impediu a transmissão vertical do vírus ao feto (MESCl et al., 2018b). Além disso, filhotes neonatais infectados pelo ZIKV tratados com SOF revelaram que sequelas de curto e longo prazo poderiam ser prevenidas (FERREIRA et al., 2017). Devido a similaridade do dominio da RNA polimerase dependente de RNA entre o HCV e ZIKV, o SOF poderia ser empregado na retenção da replicação do ZIKV e, recentemente, mostrou ser protetivo contra diferentes cepas de ZIKV, tornando-se a única droga disponível aprovada pelo FDA com capacidade protetora ao ZIKV (BULLARD-FEIBELMAN et al., 2017; SACRAMENTO et al., 2017), ilustrando o potencial translacional imediato 
através da reposição do SOF que já é usado amplamente para infecção crônica do HCV .

Em resumo, nossos resultados preenchem uma lacuna importante no conhecimento sobre a biologia do ZIKV e servem como ponto de entrada para estabelecer uma ligação mecanicista entre o ZIKV e a microcefalia. Nossos estudos também fornecem um sistema experimental para modelar o impacto do ZIKV no desenvolvimento neural e investigar os mecanismos celulares e moleculares envolvidos. De igual importância, o nosso modelo celular fornece a obtenção de uma plataforma experimental escalável para a prevenção da infecção do ZIKV em NPCs e neurônios para um possível tratamento da patologia durante o desenvolvimento neural. 


\section{CONCLUSÕES}

> O ZIKVBR é capaz de infectar NPCs, neuroesferas e neurônios;

> As NPCs apresentam uma maior expressão dos receptores AXL, implicados na maior susceptibilidade dessas células à infecção por ZIKV;

> Análises por microscopia eletrônica revelaram a presença de partículas virais citoplasmáticas em NPCs e neurônios;

> Análises por imunofluorescência detectaram agregados de proteína viral em NPCs, neuroesferas e neurônios;

> A replicação do ZIKVBR foi mais eficiente em NPCs e neurônios no MOI de 10;

> A replicação do ZIKVBR foi mais evidente em NPCs do que em neurônios no MOI de 1;

> O ZIKVBR gerou mais apoptose em NPCs do que neurônios;

> As NPCs são mais passíveis de infecção pelo ZIKVBR do que neurônios;

> As neuroesferas demonstraram evidente anormalidade morfologica após infecção pelo ZIKVBR;

> Neurônios diferenciados de NPCs infectadas pelo ZIKVBR apresentam um menor número de puncta sinápticas em relação aos controles MOCK;

> O SOF consegue resgatar NPCs e neurônios apoptóticos; 


\section{REFERÊNCIAS}

ABBINK, P.; LAROCCA, R. A.; DE LA BARRERA, R. A.; BRICAULT, C. A.; MOSELEY, E. T.; BOYD, M.; KIRILOVA, M.; LI, Z.; NG'ANG'A, D.; NANAYAKKARA, O.; NITYANANDAM, R.; MERCADO, N. B.; BORDUCCHI, E. N.; AGARWAL, A.; BRINKMAN, A. L.; CABRAL, C.; CHANDRASHEKAR, A.; GIGLIO, P. B.; JETTON, D.; JIMENEZ, J.; LEE, B. C.; MOJTA, S.; MOLLOY, K.; SHETTY, M.; NEUBAUER, G. H.; STEPHENSON, K. E.; PERON, J. P. S.; ZANOTTO, P. M. de A.; MISAMORE, J.; FINNEYFROCK, B.; LEWIS, M. G.; ALTER, G.; MODJARRAD, K.; JARMAN, R. G.; ECKELS, K. H.; MICHAEL, N. L.; THOMAS, S. J.; BAROUCH, D. H. Protective efficacy of multiple vaccine platforms against Zika virus challenge in rhesus monkeys. Science, v. $353, \quad$ n. $6304, \quad$ p. 1129-1132, 2016 . Disponível em: <http://science.sciencemag.org/content/353/6304/1129>. Acesso em: 12 maio. 2017.

ADCOCK, R. S.; CHU, Y.-K.; GOLDEN, J. E.; CHUNG, D.-H. Evaluation of anti-Zika virus activities of broad-spectrum antivirals and $\mathrm{NIH}$ clinical collection compounds using a cell-based, high-throughput screen assay. Antiviral Research, v. 138, p. 4756, 1 fev. 2017. Disponível em: <https://www.sciencedirect.com/science/article/pii/S0166354216304582?via\%3Dihub >. Acesso em: 17 abr. 2018.

BARKOVICH, A. J.; GUERRINI, R.; KUZNIECKY, R. I.; JACKSON, G. D.; DOBYNS, W. B. A developmental and genetic classification for malformations of cortical development: update 2012. Brain : a journal of neurology, v. 135, n. Pt 5, p. 134869, 2012. Disponível em: <http://www.ncbi.nlm.nih.gov/pubmed/22427329>. Acesso em: 1 fev. 2017.

BARROWS, N. J.; CAMPOS, R. K.; POWELL, S. T.; PRASANTH, K. R.; SCHOTTLERNER, G.; SOTO-ACOSTA, R.; GALARZA-MUÑOZ, G.; MCGRATH, E. L.; URRABAZ-GARZA, R.; GAO, J.; WU, P.; MENON, R.; SAADE, G.; FERNANDEZSALAS, I.; ROSSI, S. L.; VASILAKIS, N.; ROUTH, A.; BRADRICK, S. S.; GARCIABLANCO, M. A. A Screen of FDA-Approved Drugs for Inhibitors of Zika Virus Infection. Cell Host \& Microbe, v. 20, n. 2, p. 259-270, 2016 . Disponível em: $<$ http://www.sciencedirect.com/science/article/pii/S1931312816303031>. Acesso em: 12 maio. 2017.

BEARCROFT, W. Zika virus infection experimentally induced in a human volunteer. Transactions of the Royal Society of Tropical Medicine and Hygiene, V. September, n. 50(5), p. 442-448, 1956.

BELL, T. M.; FIELD, E. J.; NARANG, H. K. Zika virus infection of the central nervous system of mice. Archiv fur die gesamte Virusforschung, v. 35, n. 2, p. 183-193, 1971. 
BELTRÃO-BRAGA, P. C. B.; PIGNATARI, G. C.; RUSSO, F. B.; FERNANDES, I. R.; MUOTRI, A. R. In-a-dish: Induced pluripotent stem cells as a novel model for human diseases. Cytometry Part A, v. 83A, n. 1, p. 11-17, 2013.

BRASIL. MINISTÉRIO DA SAÚDE. SECRETARIA DE ATENÇÃO À SAÚDE. Protocolo de atenção à saúde e resposta à ocorrência de microcefalia relacionada à infecção pelo vírus Zika. [s.l: s.n.]. Disponível em: <http://www.saude.go.gov.br/public/media/ZgUINSpZiwmbr3/6462206902120440693 4.pdf>. Acesso em: 21 abr. 2017.

BRASIL. MINISTÉRIO DA SAÚDE. SECRETARIA DE VIGILâNCIA EM SAÚDE. Boletim Epidemiológico Secretaria de Vigilância em Saúde - Ministério da Saúde. [s.l: s.n.]. Disponível em: $<$ http://portalarquivos.saude.gov.br/images/pdf/2016/novembro/15/2016_031Mulheres_publicacao.pdf>. Acesso em: 2 maio. 2017.

BRASIL, P.; CALVET, G. A.; SIQUEIRA, A. M.; WAKIMOTO, M.; DE SEQUEIRA, P. C.; NOBRE, A.; QUINTANA, M. de S. B.; MENDONÇA, M. C. L. de; LUPI, O.; DE SOUZA, R. V.; ROMERO, C.; ZOGBI, H.; BRESSAN, C. da S.; ALVES, S. S.; LOURENÇO-DE-OLIVEIRA, R.; NOGUEIRA, R. M. R.; CARVALHO, M. S.; DE FILIPPIS, A. M. B.; JAENISCH, T. Zika Virus Outbreak in Rio de Janeiro, Brazil: Clinical Characterization, Epidemiological and Virological Aspects. PLOS Neglected Tropical Diseases, v. 10, n. 4, p. e0004636, 12 abr. 2016a. Disponível em: <http://www.ncbi.nlm.nih.gov/pubmed/27070912>. Acesso em: 20 fev. 2017.

BRASIL, P.; PEREIRA, J. P.; MOREIRA, M. E.; RIBEIRO NOGUEIRA, R. M.; DAMASCENO, L.; WAKIMOTO, M.; RABELLO, R. S.; VALDERRAMOS, S. G.; HALAI, U.-A.; SALLES, T. S.; ZIN, A. A.; HOROVITZ, D.; DALTRO, P.; BOECHAT, M.; RAJA GABAGLIA, C.; CARVALHO DE SEQUEIRA, P.; PILOTTO, J. H.; MEDIALDEACARRERA, R.; COTRIM DA CUNHA, D.; ABREU DE CARVALHO, L. M.; PONE, M.; MACHADO SIQUEIRA, A.; CALVET, G. A.; RODRIGUES BAIÃO, A. E.; NEVES, E. S.; NASSAR DE CARVALHO, P. R.; HASUE, R. H.; MARSCHIK, P. B.; EINSPIELER, C.; JANZEN, C.; CHERRY, J. D.; BISPO DE FILIPPIS, A. M.; NIELSEN-SAINES, K. Zika Virus Infection in Pregnant Women in Rio de Janeiro. New England Journal of Medicine, v. 375, n. 24, p. 2321-2334, 15 dez. 2016b. Disponível em: <http://www.nejm.org/doi/10.1056/NEJMoa1602412>. Acesso em: 20 fev. 2017.

BULLARD-FEIBELMAN, K. M.; GOVERO, J.; ZHU, Z.; SALAZAR, V.; VESELINOVIC, M.; DIAMOND, M. S.; GEISS, B. J. The FDA-approved drug sofosbuvir inhibits Zika virus infection. Antiviral Research, v. 137, p. 134-140, 2017. Disponível em: <http://www.sciencedirect.com/science/article/pii/S016635421630660X >. Acesso em: 12 maio. 2017. 
CALVET, G.; AGUIAR, R. S.; MELO, A. S. O.; SAMPAIO, S. A.; DE FILIPPIS, I.; FABRI, A.; ARAUJO, E. S. M.; DE SEQUEIRA, P. C.; DE MENDONÇA, M. C. L.; DE OLIVEIRA, L.; TSCHOEKE, D. A.; SCHRAGO, C. G.; THOMPSON, F. L.; BRASIL, P.; DOS SANTOS, F. B.; NOGUEIRA, R. M. R.; TANURI, A.; DE FILIPPIS, A. M. B. Detection and sequencing of Zika virus from amniotic fluid of fetuses with microcephaly in Brazil: a case study. The Lancet Infectious Diseases, v. 16, n. 6, p. 653-660, jun. 2016. Disponível em: <http://linkinghub.elsevier.com/retrieve/pii/S1473309916000955>. Acesso em: 20 fev. 2017.

CAO-LORMEAU, V.-M.; BLAKE, A.; MONS, S.; LASTĖRE, S.; ROCHE, C.; VANHOMWEGEN, J.; DUB, T.; BAUDOUIN, L.; TEISSIER, A.; LARRE, P.; VIAL, A.L.; DECAM, C.; CHOUMET, V.; HALSTEAD, S. K.; WILLISON, H. J.; MUSSET, L.; MANUGUERRA, J.-C.; DESPRES, P.; FOURNIER, E.; MALLET, H.-P.; MUSSO, D.; FONTANET, A.; NEIL, J.; GHAWCHÉ, F. Guillain-Barré Syndrome outbreak associated with Zika virus infection in French Polynesia: a case-control study. The Lancet, v. 387, n. 10027, p. 1531-1539, 2016.

CAO-LORMEAU, V.-M.; ROCHE, C.; TEISSIER, A.; ROBIN, E.; BERRY, A.-L.; MALLET, H.-P.; SALL, A. A.; MUSSO, D. Zika virus, French polynesia, South pacific, 2013. Emerging infectious diseases, v. 20, n. 6, p. 1085-6, 2014.

CAO, B.; PARNELL, L. A.; DIAMOND, M. S.; MYSOREKAR, I. U. Inhibition of autophagy limits vertical transmission of Zika virus in pregnant mice. The Journal of experimental medicine, v. 214, n. 8, p. 2303-2313, 7 ago. 2017. Disponível em: <http://www.ncbi.nlm.nih.gov/pubmed/28694387>. Acesso em: 17 abr. 2018.

CAUCHEMEZ, S.; BESNARD, M.; BOMPARD, P.; DUB, T.; GUILLEMETTE-ARTUR, P.; EYROLLE-GUIGNOT, D.; SALJE, H.; VAN KERKHOVE, M. D.; ABADIE, V.; GAREL, C.; FONTANET, A.; MALLET, H.-P. Association between Zika virus and microcephaly in French Polynesia, 2013-15: a retrospective study. Lancet (London, England), v. 387, n. 10033, p. 2125-32, 21 maio 2016. Disponível em: <http://www.ncbi.nlm.nih.gov/pubmed/26993883>. Acesso em: 1 fev. 2017.

CHAILANGKARN, T.; TRUJILLO, C. A.; FREITAS, B. C.; HRVOJ-MIHIC, B.; HERAI, R. H.; YU, D. X.; BROWN, T. T.; MARCHETTO, M. C.; BARDY, C.; MCHENRY, L.; STEFANACCI, L.; JÄRVINEN, A.; SEARCY, Y. M.; DEWITT, M.; WONG, W.; LAI, P.; ARD, M. C.; HANSON, K. L.; ROMERO, S.; JACOBS, B.; DALE, A. M.; DAI, L.; KORENBERG, J. R.; GAGE, F. H.; BELLUGI, U.; HALGREN, E.; SEMENDEFERI, K.; MUOTRI, A. R. A human neurodevelopmental model for Williams syndrome. Nature, v. 536, n. 7616, p. 338-343, 10 ago. 2016. Disponível em: <http://www.nature.com/doifinder/10.1038/nature19067>. Acesso em: 20 fev. 2017.

CHAVALI, P. L.; STOJIC, L.; MEREDITH, L. W.; JOSEPH, N.; NAHORSKI, M. S.; 
SANFORD, T. J.; SWEENEY, T. R.; KRISHNA, B. A.; HOSMILLO, M.; FIRTH, A. E.; BAYLISS, R.; MARCELIS, C. L.; LINDSAY, S.; GOODFELLOW, I.; WOODS, C. G.; GERGELY, F. Neurodevelopmental proteinMusashi-1 interactswith the Zika genome and promotes viral replication. Science, v. 357, n. June, p. 83-88, 2017.

CHEN, J.; YANG, Y.; YANG, Y.; ZOU, P.; CHEN, J.; HE, Y.; SHUI, S.; CUI, Y.; BAI, R.; LIANG, Y.; HU, Y.; JIANG, B.; LU, L.; ZHANG, X.; LIU, J.; XU, J. AXL promotes Zika virus infection in astrocytes by antagonizing type I interferon signalling. Nature Microbiology, v. 3, n. 3, p. 302-309, 29 mar. 2018. Disponível em: <http://www.nature.com/articles/s41564-017-0092-4>. Acesso em: 18 abr. 2018.

CHEUNG, A. Y. L.; HORVATH, L. M.; GRAFODATSKAYA, D.; PASCERI, P.; WEKSBERG, R.; HOTTA, A.; CARREL, L.; ELLIS, J. Isolation of MECP2-null Rett Syndrome patient hiPS cells and isogenic controls through X-chromosome inactivation. Human Molecular Genetics, v. 20, n. 11, p. 2103-2115, 2011.

COSTELLO, A.; DUA, T.; DURA, P.; GÜLMEZOGLU, M.; OLADAPO, O. T.; PEREA, W.; PIRES, J.; RAMON-PARDO, P.; ROLLINS, N.; SAXENA, S. Defining the syndrome associated with congenital Zika virus infection. Bulletin of the World Health Organization, v. 94, p. 406-406A, 2016. Disponível em: <http://www.who.int/bulletin/volumes/94/6/16-176990/en/>. Acesso em: 29 maio. 2017.

CUGOLA, F. R.; FERNANDES, I. R.; RUSSO, F. B.; FREITAS, B. C.; DIAS, J. L. M.; GUIMARAES, K. P.; BENAZZATO, C.; ALMEIDA, N.; PIGNATARI, G. C.; ROMERO, S.; POLONIO, C. M.; CUNHA, I.; FREITAS, C. L.; BRANDAO, W. N.; ROSSATO, C.; ANDRADE, D. G.; FARIA, D. de P.; GARCEZ, A. T.; BUCHPIGEL, C. A.; BRACONI, C. T.; MENDES, E.; SALL, A. A.; ZANOTTO, P. M. de A.; PERON, J. P. S.; MUOTRI, A. R.; BELTRAO-BRAGA, P. C. B. The Brazilian Zika Virus Strain Causes Birth Defects in Experimental Models. Nature, v. 534, n. 7606, p. 267-271, jun. 2016.

D'AIUTO, L.; DI MAIO, R.; HEATH, B.; RAIMONDI, G.; MILOSEVIC, J.; WATSON, A. M.; BAMNE, M.; PARKS, W. T.; YANG, L.; LIN, B.; MIKI, T.; MICH-BASSO, J. D.; ARAV-BOGER, R.; SIBILLE, E.; SABUNCIYAN, S.; YOLKEN, R.; NIMGAONKAR, V. Human Induced Pluripotent Stem Cell-Derived Models to Investigate Human Cytomegalovirus Infection in Neural Cells. PLoS ONE, v. 7, n. 11, p. e49700, 27 nov. 2012. Disponível em: <http://dx.plos.org/10.1371/journal.pone.0049700>. Acesso em: 8 maio. 2017.

D'ORTENZIO, E.; MATHERON, S.; DE LAMBALLERIE, X.; HUBERT, B.; PIORKOWSKI, G.; MAQUART, M.; DESCAMPS, D.; DAMOND, F.; YAZDANPANAH, Y.; LEPARC-GOFFART, I. Evidence of Sexual Transmission of Zika Virus. New England Journal of Medicine, v. 374, n. 22, p. 2195-2198, 2016. 
DANG, J.; TIWARI, S. K.; LICHINCHI, G.; QIN, Y.; PATIL, V. S.; EROSHKIN, A. M.; RANA, T. M. Zika Virus Depletes Neural Progenitors in Human Cerebral Organoids through Activation of the Innate Immune Receptor TLR3. Cell Stem Cell, v. 19, n. 2, p. 258-265, ago. 2016. Disponível em: <http://linkinghub.elsevier.com/retrieve/pii/S1934590916300571>. Acesso em: 15 mar. 2017.

DE FATIMA VASCO ARAGAO, M.; VAN DER LINDEN, V.; BRAINER-LIMA, A. M.; COELI, R. R.; ROCHA, M. A.; SOBRAL DA SILVA, P.; DURCE COSTA GOMES DE CARVALHO, M.; VAN DER LINDEN, A.; CESARIO DE HOLANDA, A.; VALENCA, M. $M$. Clinical features and neuroimaging (CT and MRI) findings in presumed Zika virus related congenital infection and microcephaly: retrospective case series study. BMJ, v. 353, 2016.

DE OLIVEIRA, W. K.; CORTEZ-ESCALANTE, J.; GONÇALVES HOLANDA DE OLIVEIRA, W. T.; IKEDA DO CARMO, G. M.; PESSANHA HENRIQUES, C. M.; COELHO, G. E.; ARAÚJO DE FRANÇA, G. V. Increase in Reported Prevalence of Microcephaly in Infants Born to Women Living in Areas with Confirmed Zika Virus Transmission During the First Trimester of Pregnancy - Brazil, 2015. MMWR: Morbidity \& Mortality Weekly Report, v. 65, n. 9, p. 242-247, 2016.

DIAMOND, M. S. Evasion of innate and adaptive immunity by flaviviruses. Immunology and Cell Biology, v. 81, n. 3, p. 196-206, 1 jun. 2003. Disponível em: <http://doi.wiley.com/10.1046/j.1440-1711.2003.01157.x>. Acesso em: 17 abr. 2018.

DICK, G.; KITCHEN, S.; HADDOW, A. Zika virus. I. Isolations and serelogical specificity. Transactions of the Royal Society of Tropical Medicine and Hygiene, v. September, n. 46(5), p. 509-520, 1952.

DUFFY, M. R.; CHEN, T.-H.; HANCOCK, W. T.; POWERS, A. M.; KOOL, J. L.; LANCIOTTI, R. S.; PRETRICK, M.; MARFEL, M.; HOLZBAUER, S.; DUBRAY, C.; GUILLAUMOT, L.; GRIGGS, A.; BEL, M.; LAMBERT, A. J.; LAVEN, J.; KOSOY, O.; PANELLA, A.; BIGGERSTAFF, B. J.; FISCHER, M.; HAYES, E. B. Zika Virus Outbreak on Yap Island, Federated States of Micronesia. The New England Journal of Medicine, v. 360, n. 24, p. 2536-2543, 11 jun. 2009. Disponível em: <http://www.nejm.org/doi/abs/10.1056/NEJMoa0805715>. Acesso em: 24 nov. 2016.

EBERT, A. D.; YU, J.; ROSE, F. F.; MATTIS, V. B.; LORSON, C. L.; THOMSON, J. A.; SVENDSEN, C. N.; SVENDSEN, C. N. Induced pluripotent stem cells from a spinal muscular atrophy patient. Nature, v. 457, n. 7227, p. 277-80, 15 jan. 2009. Disponível em: <http://www.ncbi.nlm.nih.gov/pubmed/19098894>. Acesso em: 4 maio. 2017.

ELFIKY, A. A.; ELSHEMEY, W. M.; GAWAD, W. A.; DESOKY, O. S. Molecular Modeling Comparison of the Performance of NS5b Polymerase Inhibitor (PSI-7977) 
on Prevalent HCV Genotypes. The Protein Journal, v. 32, n. 1, p. 75-80, 16 jan. 2013. Disponível em: <http://link.springer.com/10.1007/s10930-013-9462-9>. Acesso em: 14 maio. 2017.

EYER, L.; NENCKA, R.; HUVAROVÁ, I.; PALUS, M.; JOAO ALVES, M.; GOULD, E. A.; DE CLERCQ, E.; RŮŽEK, D. Nucleoside Inhibitors of Zika Virus. Journal of Infectious Diseases, v. 214, n. 5, p. 707-711, 1 set. 2016. Disponível em: $<$ https://academic.oup.com/jid/article-lookup/doi/10.1093/infdis/jiw226>. Acesso em: 17 abr. 2018.

FAGBAMI, A. H. Zika virus infections in Nigeria: virological and seroepidemiological investigations in Oyo State. The Journal of hygiene, v. 83, n. 2, p. 213-219, 1979.

FARIA, N. R.; AZEVEDO, R. do S. da S.; KRAEMER, M. U. G.; SOUZA, R.; CUNHA, M. S.; HILL, S. C.; THÉZÉ, J.; BONSALL, M. B.; BOWDEN, T. A.; RISSANEN, I.; ROCCO, I. M.; NOGUEIRA, J. S.; MAEDA, A. Y.; VASAMI, F. G. da S.; MACEDO, F. L. de L.; SUZUKI, A.; RODRIGUES, S. G.; CRUZ, A. C. R.; NUNES, B. T.; MEDEIROS, D. B. de A.; RODRIGUES, D. S. G.; NUNES QUEIROZ, A. L.; DA SILVA, E. V. P.; HENRIQUES, D. F.; TRAVASSOS DA ROSA, E. S.; DE OLIVEIRA, C. S.; MARTINS, L. C.; VASCONCELOS, H. B.; CASSEB, L. M. N.; SIMITH, D. de B.; MESSINA, J. P.; ABADE, L.; LOURENÇO, J.; CARLOS JUNIOR ALCANTARA, L.; DE LIMA, M. M.; GIOVANETTI, M.; HAY, S. I.; DE OLIVEIRA, R. S.; LEMOS, P. da S.; DE OLIVEIRA, L. F.; DE LIMA, C. P. S.; DA SILVA, S. P.; DE VASCONCELOS, J. M.; FRANCO, L.; CARDOSO, J. F.; VIANEZ-JÚNIOR, J. L. da S. G.; MIR, D.; BELLO, G.; DELATORRE, E.; KHAN, K.; CREATORE, M.; COELHO, G. E.; DE OLIVEIRA, W. K.; TESH, R.; PYBUS, O. G.; NUNES, M. R. T.; VASCONCELOS, P. F. C. Zika virus in the Americas: Early epidemiological and genetic findings. Science, v. 352, n. 6283, p. 345-349, 2016.

FAYE, O.; FREIRE, C. C. M.; IAMARINO, A.; FAYE, O.; DE OLIVEIRA, J. V. C.; DIALLO, M.; ZANOTTO, P. M. A.; SALL, A. A. Molecular Evolution of Zika Virus during Its Emergence in the 20th Century. PLoS Negl Trop Dis, v. 8, n. 1, p. e2636, 2014.

FERREIRA, A. C.; ZAVERUCHA-DO-VALLE, C.; REIS, P. A.; BARBOSA-LIMA, G.; VIEIRA, Y. R.; MATTOS, M.; SILVA, P. de P.; SACRAMENTO, C.; DE CASTRO FARIA NETO, H. C.; CAMPANATI, L.; TANURI, A.; BRÜNING, K.; BOZZA, F. A.; BOZZA, P. T.; SOUZA, T. M. L. Sofosbuvir protects Zika virus-infected mice from mortality, preventing short- and long-term sequelae. Scientific Reports, v. 7, n. 1, p. 9409, 25 dez. 2017. Disponível em: <http://www.nature.com/articles/s41598-01709797-8>. Acesso em: 17 abr. 2018.

GABRIEL, E.; RAMANI, A.; KAROW, U.; GOTTARDO, M.; NATARAJAN, K.; GOOI, L. M.; GORANCI-BUZHALA, G.; KRUT, O.; PETERS, F.; NIKOLIC, M.; KUIVANEN, S.; KORHONEN, E.; SMURA, T.; VAPALAHTI, O.; PAPANTONIS, A.; SCHMIDT- 
CHANASIT, J.; RIPARBELLI, M.; CALLAINI, G.; KRÖNKE, M.; UTERMÜHLEN, O.; GOPALAKRISHNAN, J. Recent Zika Virus Isolates Induce Premature Differentiation of Neural Progenitors in Human Brain Organoids. Cell Stem Cell, v. 20, n. 3, p. 397406.e5, 2 mar. 2017.2 Disponível em: <http://www.ncbi.nlm.nih.gov/pubmed/28132835>. Acesso em: 14 abr. 2017.

GARCEZ, P. P.; LOIOLA, E. C.; MADEIRO DA COSTA, R.; HIGA, L. M.; TRINDADE, P.; DELVECCHIO, R.; NASCIMENTO, J. M.; BRINDEIRO, R.; TANURI, A.; REHEN, S. K. Zika virus impairs growth in human neurospheres and brain organoids. Science, v. 352, n. 6287, p. 816-818, 2016.

GENTILE, I.; MARAOLO, A. E.; BUONOMO, A. R.; ZAPPULO, E.; BORGIA, G. The discovery of sofosbuvir: a revolution for therapy of chronic hepatitis $C$. Expert Opinion on Drug Discovery, v. 10, n. 12, p. 1363-1377, 2 dez. 2015. Disponível em: <http://www.tandfonline.com/doi/full/10.1517/17460441.2015.1094051>. Acesso em: 14 maio. 2017.

GÉRARDIN, P.; SAMPÉRIZ, S.; RAMFUL, D.; BOUMAHNI, B.; BINTNER, M.; ALESSANDRI, J.-L.; CARBONNIER, M.; TIRAN-RAJAOEFERA, I.; BEULLIER, G.; BOYA, I.; NOORMAHOMED, T.; OKOÏ, J.; ROLLOT, O.; COTTE, L.; JAFFARBANDJEE, M.-C.; MICHAULT, A.; FAVIER, F.; KAMINSKI, M.; FOURMAINTRAUX, A.; FRITEL, X. Neurocognitive outcome of children exposed to perinatal mother-tochild Chikungunya virus infection: the CHIMERE cohort study on Reunion Island. PLoS neglected tropical diseases, v. 8, n. 7, p. e2996, jul. 2014. Disponível em: <http://www.ncbi.nlm.nih.gov/pubmed/25033077>. Acesso em: 20 fev. 2017.

GOURINAT, A.-C.; O'CONNOR, O.; CALVEZ, E.; GOARANT, C.; DUPONTROUZEYROL, M. Detection of Zika virus in urine. Emerging infectious diseases, v. 21, n. 1, p. 84-6, jan. 2015. Disponível em: <http://www.ncbi.nlm.nih.gov/pubmed/25530324>. Acesso em: 1 fev. 2017.

GRANT, A.; PONIA, S. S.; TRIPATHI, S.; BALASUBRAMANIAM, V.; MIORIN, L.; SOURISSEAU, M.; SCHWARZ, M. C.; SÁNCHEZ-SECO, M. P.; EVANS, M. J.; BEST, S. M.; GARCÍA-SASTRE, A. Zika Virus Targets Human STAT2 to Inhibit Type I Interferon Signaling. Cell Host \& Microbe, v. 19, n. 6, p. 882-890, 8 jun. 2016. Disponível em: <https://www.sciencedirect.com/science/article/pii/S1931312816302050>. Acesso em: 17 abr. 2018.

GRIESI-OLIVEIRA, K.; ACAB, A.; GUPTA, A. R.; SUNAGA, D. Y.; CHAILANGKARN, T.; NICOL, X.; NUNEZ, Y.; WALKER, M. F.; MURDOCH, J. D.; SANDERS, S. J.; FERNANDEZ, T. V; JI, W.; LIFTON, R. P.; VADASZ, E.; DIETRICH, A.; PRADHAN, D.; SONG, H.; MING, G.-L.; GU, X.; HADDAD, G.; MARCHETTO, M. C. N.; SPITZER, N.; PASSOS-BUENO, M. R.; STATE, M. W.; MUOTRI, A. R. Modeling non-syndromic 
autism and the impact of TRPC6 disruption in human neurons. Molecular Psychiatry, v. 20 , n. 11 , p. 1350-65, 2015.

GUERRINI, R.; DOBYNS, W. B. Malformations of cortical development: clinical features and genetic causes. The Lancet Neurology, v. 13, n. 7, p. 710-726, 2014.

GUNDELFINGER, E. D.; REISSNER, C.; GARNER, C. C. Role of Bassoon and Piccolo in Assembly and Molecular Organization of the Active Zone. Frontiers in synaptic neuroscience, v. 7, p. 19, 2015. Disponível em: <http://www.ncbi.nlm.nih.gov/pubmed/26793095>. Acesso em: 26 abr. 2018.

HADDOW, A. J.; WILLIAMS, M. C.; WOODALL, J. P.; SIMPSON, D. I.; GOMA, L. K. TWELVE ISOLATIONS OF ZIKA VIRUS FROM AEDES (STEGOMYIA) AFRICANUS (THEOBALD) TAKEN IN AND ABOVE A UGANDA FOREST. Bulletin of the World Health Organization, v. 31, n. 1, p. 57-69, 1964.

HAMEL, R.; DEJARNAC, O.; WICHIT, S.; EKCHARIYAWAT, P.; NEYRET, A.; LUPLERTLOP, N.; PERERA-LECOIN, M.; SURASOMBATPATTANA, P.; TALIGNANI, L.; THOMAS, F.; CAO-LORMEAU, V.-M.; CHOUMET, V.; BRIANT, L.; DESPRÈS, P.; AMARA, A.; YSSEL, H.; MISSÉ, D. Biology of Zika Virus Infection in Human Skin Cells. Journal of Virology, v. 89, n. 17, p. 8880-96, 2015.

HASTINGS, A. K.; YOCKEY, L. J.; JAGGER, B. W.; HWANG, J.; URAKI, R.; GAITSCH, H. F.; PARNELL, L. A.; CAO, B.; MYSOREKAR, I. U.; ROTHLIN, C. V; FIKRIG, E.; DIAMOND, M. S.; IWASAKI, A. TAM Receptors Are Not Required for Zika Virus Infection in Mice. Cell reports, v. 19, n. 3, p. 558-568, 2017. Disponível em: <http://www.ncbi.nlm.nih.gov/pubmed/28423319>. Acesso em: 18 abr. 2018.

IMIG, C.; MIN, S.-W.; KRINNER, S.; ARANCILLO, M.; ROSENMUND, C.; SÜDHOF, T. C.; RHEE, J.; BROSE, N.; COOPER, B. H. The Morphological and Molecular Nature of Synaptic Vesicle Priming at Presynaptic Active Zones. Neuron, v. 84, n. 2, p. 416431, 22 out. 2014.2 Disponível <https://www.sciencedirect.com/science/article/pii/S0896627314009076?via\%3Dihub >. Acesso em: 26 abr. 2018.

ISRAEL, M. A.; YUAN, S. H.; BARDY, C.; REYNA, S. M.; MU, Y.; HERRERA, C.; HEFFERAN, M. P.; VAN GORP, S.; NAZOR, K. L.; BOSCOLO, F. S.; CARSON, C. T.; LAURENT, L. C.; MARSALA, M.; GAGE, F. H.; REMES, A. M.; KOO, E. H.; GOLDSTEIN, L. S. B. Probing sporadic and familial Alzheimer's disease using induced pluripotent stem cells. Nature, v. 482, n. 7384, p. 216-20, 2012.

JURADO, K. A.; SIMONI, M. K.; TANG, Z.; URAKI, R.; HWANG, J.; HOUSEHOLDER, 
S.; WU, M.; LINDENBACH, B. D.; ABRAHAMS, V. M.; GULLER, S.; FIKRIG, E. Zika virus productively infects primary human placenta-specific macrophages. JCI Insight, v. 1, n. 13, p. 1-6, 2016.

KELAVA, I.; LANCASTER, M. A. Dishing out mini-brains: Current progress and future prospects in brain organoid research. Developmental biology, v. 420, n. 2, p. 199209, 15 dez. 2016. Disponível em: <http://www.ncbi.nlm.nih.gov/pubmed/27402594>. Acesso em: 4 maio. 2017.

$\mathrm{KIM}$, C. iPSC technology--Powerful hand for disease modeling and therapeutic screen. BMB reports, v. 48, n. 5, p. 256-65, maio 2015. Disponível em: <http://www.ncbi.nlm.nih.gov/pubmed/25104399>. Acesso em: 29 maio. 2018.

KOSTYUCHENKO, V. A.; LIM, E. X. Y.; ZHANG, S.; FIBRIANSAH, G.; NG, T.-S.; OOI, J. S. G.; SHI, J.; LOK, S.-M. Structure of the thermally stable Zika virus. Nature, v. 533, p. 425-428, 19 abr. 2016. Disponível em: <http://www.nature.com/doifinder/10.1038/nature17994>. Acesso em: 20 fev. 2017.

LANCASTER, M. A.; RENNER, M.; MARTIN, C.-A.; WENZEL, D.; BICKNELL, L. S.; HURLES, M. E.; HOMFRAY, T.; PENNINGER, J. M.; JACKSON, A. P.; KNOBLICH, J. A. Cerebral organoids model human brain development and microcephaly. Nature, v. $501, \quad$ n. 7467, p. 373-9, 19 set. 2013. Disponível em: <http://www.ncbi.nlm.nih.gov/pubmed/23995685>. Acesso em: 20 fev. 2017.

LANCIOTTI, R. S.; KOSOY, O. L.; LAVEN, J. J.; VELEZ, J. O.; LAMBERT, A. J.; JOHNSON, A. J.; STANFIELD, S. M.; DUFFY, M. R. Genetic and serologic properties of Zika virus associated with an epidemic, Yap State, Micronesia, 2007. Emerging Infectious Diseases, v. 14, n. 8, p. 1232-1239, 2008.

LANG, J.; VERA, D.; CHENG, Y.; TANG, H. Modeling Dengue Virus-Hepatic Cell Interactions Using Human Pluripotent Stem Cell-Derived Hepatocyte-like Cells. Stem cell reports, v. 7, n. 3, p. $341-54,13$ set. 2016. Disponível em: <http://www.ncbi.nlm.nih.gov/pubmed/27546535>. Acesso em: 14 abr. 2017.

LAROCCA, R. A.; ABBINK, P.; PERON, J. P. S.; DE A. ZANOTTO, P. M.; IAMPIETRO, M. J.; BADAMCHI-ZADEH, A.; BOYD, M.; NG'ANG'A, D.; KIRILOVA, M.; NITYANANDAM, R.; MERCADO, N. B.; LI, Z.; MOSELEY, E. T.; BRICAULT, C. A.; BORDUCCHI, E. N.; GIGLIO, P. B.; JETTON, D.; NEUBAUER, G.; NKOLOLA, J. P.; MAXFIELD, L. F.; DE LA BARRERA, R. A.; JARMAN, R. G.; ECKELS, K. H.; MICHAEL, N. L.; THOMAS, S. J.; BAROUCH, D. H. Vaccine protection against Zika virus from Brazil. Nature, v. 536, n. 7617, p. 474-478, 25 ago. 2016. Disponível em: <http://dx.doi.org/10.1038/nature18952>. 
LEMKE, G. Biology of the TAM Receptors. Cold Spring Harbor Perspectives in Biology, v. 5, n. 11, p. a009076-a009076, 2013.

LEMKE, G.; ROTHLIN, C. V. Immunobiology of the TAM receptors. Nature Reviews Immunology, v. 8, n. 5, p. 327-336, 2008.

LI, C.; XU, D.; YE, Q.; HONG, S.; JIANG, Y.; LIU, X.; ZHANG, N.; SHI, L.; QIN, C.-F.; XU, Z. Zika Virus Disrupts Neural Progenitor Development and Leads to Microcephaly in Mice. Cell Stem Cell, v. 19, n. 1, p. 120-126, 7 jul. 2016. Disponível em: <http://www.ncbi.nlm.nih.gov/pubmed/27179424>. Acesso em: 22 fev. 2017.

LI, C.; ZHU, X.; JI, X.; QUANQUIN, N.; DENG, Y.-Q.; TIAN, M.; ALIYARI, R.; ZUO, X.; YUAN, L.; AFRIDI, S. K.; LI, X.-F.; JUNG, J. U.; NIELSEN-SAINES, K.; QIN, F. X.-F.; QIN, C.-F.; XU, Z.; CHENG, G. Chloroquine, a FDA-approved Drug, Prevents Zika Virus Infection and its Associated Congenital Microcephaly in Mice. EBioMedicine, v. 24, p. 189-194, out. $2017 . \quad$ Disponível em: <http://www.ncbi.nlm.nih.gov/pubmed/29033372>. Acesso em: 17 abr. 2018.

LINDENBACH, B. D.; RICE, C. M. Molecular biology of flaviviruses. Advances in Virus Research, v. 59, n. Lindenback, B., Rice, C. (2003). Molecular biology of flavivirus, 59, 23-61., p. 23-61, 2003.

LIU, J.; KOSCIELSKA, K. A.; CAO, Z.; HULSIZER, S.; GRACE, N.; MITCHELL, G.; NACEY, C.; GITHINJI, J.; MCGEE, J.; GARCIA-AROCENA, D.; HAGERMAN, R. J.; NOLTA, J.; PESSAH, I. N.; HAGERMAN, P. J. Signaling defects in iPSC-derived fragile $X$ premutation neurons. Human molecular genetics, v. 21, n. 17, p. 3795-805, 1 set. 2012. Disponível em: <http://www.ncbi.nlm.nih.gov/pubmed/22641815>. Acesso em: 21 jun. 2017.

LUSTIG, Y.; MENDELSON, E.; PARAN, N.; MELAMED, S.; SCHWARTZ, E. Detection of Zika virus RNA in whole blood of imported Zika virus disease cases up to 2 months after symptom onset, Israel, December 2015 to April 2016. Eurosurveillance, v. 21, n. 26, p. 30269, 30 jun. 2016. Disponível em: <http://www.eurosurveillance.org/ViewArticle.aspx?Articleld=22515>. Acesso em: 1 fev. 2017.

MACNAMARA, F. N. Zika virus: a report on three cases of human infection during an epidemic of jaundice in Nigeria. Transactions of the Royal Society of Tropical Medicine and Hygiene, v. 48, n. 2, p. 139-45, 1954.

MARCHETTE, N. J.; GARCIA, R.; RUDNICK, A. Isolation of Zika virus from Aedes 
aegypti mosquitoes in Malaysia. The American Journal of Tropical Medicine and Hygiene, v. 18, n. 3, p. 411-5, 1969.

MARCHETTO, M. C.; BELINSON, H.; TIAN, Y.; FREITAS, B. C.; FU, C.; VADODARIA, K. C.; BELTRAO-BRAGA, P. C.; TRUJILLO, C. A.; MENDES, A. P. D.; PADMANABHAN, K.; NUNEZ, Y.; OU, J.; GHOSH, H.; WRIGHT, R.; BRENNAND, K. J.; PIERCE, K.; EICHENFIELD, L.; PRAMPARO, T.; EYLER, L. T.; BARNES, C. C.; COURCHESNE, E.; GESCHWIND, D. H.; GAGE, F. H.; WYNSHAW-BORIS, A.; MUOTRI, A. R. Altered proliferation and networks in neural cells derived from idiopathic autistic individuals. Molecular Psychiatry, 5 jul. 2016. Disponível em: <http://www.ncbi.nlm.nih.gov/pubmed/27378147>. Acesso em: 20 fev. 2017.

MARCHETTO, M. C. N. M.; CARROMEU, C.; ACAB, A.; YU, D.; YEO, G. W.; MU, Y.; CHEN, G.; GAGE, F. H.; MUOTRI, A. R. A model for neural development and treatment of Rett syndrome using human induced pluripotent stem cells. Cell, v. 143, n. 4 , p. 527-39, 2010. Disponível em: $<$ http://www.pubmedcentral.nih.gov/articlerender.fcgi?artid=3003590\&tool=pmcentre z\&rendertype=abstract\%5Cnhttp://www.sciencedirect.com/science/article/pii/S00928 67410011864\%5Cnhttp://www.pubmedcentral.nih.gov/articlerender.fcgi?artid=30035 90\&tool=pmcentrez\&rend $>$.

MARCHETTO, M. C. N.; WINNER, B.; GAGE, F. H. Pluripotent stem cells in neurodegenerative and neurodevelopmental diseases. Human molecular genetics, v. 19, n. R1, p. R71-6, 15 abr. 2010. Disponível em: <http://www.ncbi.nlm.nih.gov/pubmed/20418487>. Acesso em: 4 maio. 2017.

MARIANI, J.; COPPOLA, G.; ZHANG, P.; ABYZOV, A.; PROVINI, L.; TOMASINI, L.; AMENDUNI, M.; SZEKELY, A.; PALEJEV, D.; WILSON, M.; GERSTEIN, M.; GRIGORENKO, E. L.; CHAWARSKA, K.; PELPHREY, K. A.; HOWE, J. R.; VACCARINO, F. M. FOXG1-Dependent Dysregulation of GABA/Glutamate Neuron Differentiation in Autism Spectrum Disorders. Cell, v. 162, n. 2, p. 375-90, 16 jul. 2015. Disponível em: <http://www.ncbi.nlm.nih.gov/pubmed/26186191>. Acesso em: 4 maio. 2017.

MARTINES, R. B.; BHATNAGAR, J.; KEATING, M. K.; SILVA-FLANNERY, L.; MUEHLENBACHS, A.; GARY, J.; GOLDSMITH, C.; HALE, G.; RITTER, J.; ROLLIN, D.; SHIEH, W.-J.; LUZ, K. G.; RAMOS, A. M. de O.; DAVI, H. P. F.; KLEBER DE OLIVERIA, W.; LANCIOTTI, R.; LAMBERT, A.; ZAKI, S. Notes from the Field: Evidence of Zika Virus Infection in Brain and Placental Tissues from Two Congenitally Infected Newborns and Two Fetal Losses - Brazil, 2015. MMWR. Morbidity and Mortality Weekly Report, v. 65, n. 06, p. 1-2, 10 fev. 2016. Disponível em: <http://www.cdc.gov/mmwr/volumes/65/wr/mm6506e1er.htm>. Acesso em: 18 jun. 2016. 
MCCARTHY, M. Zika virus was transmitted by sexual contact in Texas, health officials report. BMJ, v. 352, 2016.

MEERTENS, L.; CARNEC, X.; LECOIN, M. P.; RAMDASI, R.; GUIVEL-BENHASSINE, F.; LEW, E.; LEMKE, G.; SCHWARTZ, O.; AMARA, A. The TIM and TAM Families of Phosphatidylserine Receptors Mediate Dengue Virus Entry. Cell Host \& Microbe, v. 12, n. 4, p. 544-557, 18 out. 2012. Disponível em: $<$ https://www.sciencedirect.com/science/article/pii/S1931312812003046?via\%3Dihub >. Acesso em: 17 abr. 2018.

MEERTENS, L.; LABEAU, A.; DEJARNAC, O.; GRESSENS, P.; SCHWARTZ, O.; AMARA, A.; CIPRIANI, S.; SINIGAGLIA, L.; BONNET-MADIN, L.; CHARPENTIER, T. Le; HAFIRASSOU, M. L.; ZAMBORLINI, A.; CAO-LORMEAU, V.-M.; COULPIER, M.; MISSÉ, D. E.; JOUVENET, N.; TABIBIAZAR, R. AxI Mediates ZIKA Virus Entry in Human Glial Cells and Modulates Innate Immune Responses. Cell Reports, v. 18, p. 324-333, 2017. Disponível em: <http://dx.doi.org/10.1016/j.celrep.2016.12.045>. Acesso em: 10 abr. 2018.

MESCI, P.; MACIA, A.; LAROCK, C. N.; TEJWANI, L.; FERNANDES, I. R.; SUAREZ, N. A.; DE A. ZANOTTO, P. M.; BELTRÃO-BRAGA, P. C. B.; NIZET, V.; MUOTRI, A. R. Modeling neuro-immune interactions during Zika virus infection. Human Molecular Genetics, v. 27, n. 1, p. 41-52, 1 jan. 2018a. Disponível em: <https://academic.oup.com/hmg/article/27/1/41/4557143>. Acesso em: 17 abr. 2018.

MESCI, P.; MACIA, A.; MOORE, S. M.; SHIRYAEV, S. A.; PINTO, A.; HUANG, C.-T.; TEJWANI, L.; FERNANDES, I. R.; SUAREZ, N. A.; KOLAR, M. J.; MONTEFUSCO, S.; ROSENBERG, S. C.; HERAI, R. H.; CUGOLA, F. R.; RUSSO, F. B.; SHEETS, N.; SAGHATELIAN, A.; SHRESTA, S.; MOMPER, J. D.; SIQUEIRA-NETO, J. L.; CORBETT, K. D.; BELTRÃO-BRAGA, P. C. B.; TERSKIKH, A. V.; MUOTRI, A. R. Blocking Zika virus vertical transmission. Scientific Reports, v. 8, n. 1, p. 1218, 19 dez. 2018b. Disponível em: <http://www.nature.com/articles/s41598-018-19526-4>. Acesso em: 28 mar. 2018.

MING, G.; TANG, H.; SONG, H. Advances in Zika Virus Research: Stem Cell Models, Challenges, and Opportunities. Cell Stem Cell, v. 19, n. 6, p. 690-702, dez. 2016. Disponível em: <http://linkinghub.elsevier.com/retrieve/pii/S1934590916304155>. Acesso em: 10 maio. 2017.

MLAKAR, J.; KORVA, M.; TUL, N.; POPOVIĆ, M.; POLJŠAK-PRIJATELJ, M.; MRAZ, J.; KOLENC, M.; RESMAN RUS, K.; VESNAVER VIPOTNIK, T.; FABJAN VODUŠEK, V.; VIZJAK, A.; PIŽEM, J.; PETROVEC, M.; AVŠIČ ŽUPANC, T. Zika Virus Associated with Microcephaly. New England Journal of Medicine, v. 374, n. 10, p. 951-958, 2016. 
MOORE, C. A.; STAPLES, J. E.; DOBYNS, W. B.; PESSOA, A.; VENTURA, C. V.; FONSECA, E. B. da; RIBEIRO, E. M.; VENTURA, L. O.; NETO, N. N.; ARENA, J. F.; RASMUSSEN, S. A. Characterizing the Pattern of Anomalies in Congenital Zika Syndrome for Pediatric Clinicians. JAMA Pediatrics, v. 171, n. 3, p. 288, 2017. Disponível em: <http://archpedi.jamanetwork.com/article.aspx?doi=10.1001/jamapediatrics.2016.398 $2>$.

MOORE, D.; CAUSEY, O.; CAREY, D.; REDDY, S.; COOKE, A.; AKINKUGBE, F.; DAVID-WEST, T.; KEMP, G. Arthropode-borne viral infections of man in Nigeria, 19641970. Annals of Tropical Medicine and Parasitology, v. March, n. 69(1), p. 49-64, 1975.

MULLARD, A. Stem-cell discovery platforms yield first clinical candidates. Nature Reviews Drug Discovery, v. 14, n. 9, p. 589-591, 2015.

MUSSO, D.; ROCHE, C.; NHAN, T.-X.; ROBIN, E.; TEISSIER, A.; CAO-LORMEAU, V.-M. Detection of Zika virus in saliva. Journal of Clinical Virology, v. 68, p. 53-55, $2015 a$.

MUSSO, D.; ROCHE, C.; ROBIN, E.; NHAN, T.; TEISSIER, A.; CAO-LORMEAU, V.M. Potential sexual transmission of Zika virus. Emerging infectious diseases, v. 21, n. 2, p. 359-61, fev. 2015b. Disponível em: <http://www.ncbi.nlm.nih.gov/pubmed/25625872>. Acesso em: 1 fev. 2017.

NAKAO, T.; CHIBA, S. Cytomegalovirus and Microcephaly. Pediatrics, v. 46, n. 3, 1970.

NOWAKOWSKI, T. J.; POLLEN, A. A.; DI LULLO, E.; SANDOVAL-ESPINOSA, C.; BERSHTEYN, M.; KRIEGSTEIN, A. R. Expression Analysis Highlights AXL as a Candidate Zika Virus Entry Receptor in Neural Stem Cells. Cell Stem Cell, v. 18, n. 5, p. 591-596, 2016.

O'LEARY, D. R.; KUHN, S.; KNISS, K. L.; HINCKLEY, A. F.; RASMUSSEN, S. A.; PAPE, W. J.; KIGHTLINGER, L. K.; BEECHAM, B. D.; MILLER, T. K.; NEITZEL, D. F.; MICHAELS, S. R.; CAMPBELL, G. L.; LANCIOTTI, R. S.; HAYES, E. B. Birth Outcomes Following West Nile Virus Infection of Pregnant Women in the United States: 2003-2004. Pediatrics, v. 117, n. 3, 2006.

OEHLER, E.; WATRIN, L.; LARRE, P.; LEPARC-GOFFART, I.; LASTERE, S.; VALOUR, F.; BAUDOUIN, L.; MALLET, H.; MUSSO, D.; GHAWCHE, F.; CAO- 
LORMEAU, V. M. Zika virus infection complicated by Guillain-Barre syndrome--case report, French Polynesia, December 2013. Emerging Infectious Diseases, v. 19, n. 11, p. 1960, 2014.

ONORATI, M.; LI, Z.; LIU, F.; SOUSA, A. M. M. M. M.; NAKAGAWA, N.; LI, M.; DELL'ANNO, M. T.; GULDEN, F. O. O.; POCHAREDDY, S.; TEBBENKAMP, A. T. N. T. N.; HAN, W.; PLETIKOS, M.; GAO, T.; ZHU, Y.; BICHSEL, C.; VARELA, L.; SZIGETI-BUCK, K.; LISGO, S.; ZHANG, Y.; TESTEN, A.; GAO, X.-B. B.; MLAKAR, J.; POPOVIC, M.; FLAMAND, M.; STRITTMATTER, S. M. M.; KACZMAREK, L. K. K.; ANTON, E. S. S.; HORVATH, T. L. L.; LINDENBACH, B. D. D.; SESTAN, N.; DELL'ANNO, M. T.; GULDEN, F. O. O.; POCHAREDDY, S.; TEBBENKAMP, A. T. N. T. N.; HAN, W.; PLETIKOS, M.; GAO, T.; ZHU, Y.; BICHSEL, C.; VARELA, L.; SZIGETI-BUCK, K.; LISGO, S.; ZHANG, Y.; TESTEN, A.; GAO, X.-B. B.; MLAKAR, J.; POPOVIC, M.; FLAMAND, M.; STRITTMATTER, S. M. M.; KACZMAREK, L. K. K.; ANTON, E. S. S.; HORVATH, T. L. L.; LINDENBACH, B. D. D.; SESTAN, N. Zika Virus Disrupts Phospho-TBK1 Localization and Mitosis in Human Neuroepithelial Stem Cells and Radial Glia. Cell Reports, v. 16, n. 10, 6 set. 2016. Disponível em: <https://www.sciencedirect.com/science/article/pii/S2211124716311020?via\%3Dihub >. Acesso em: 20 fev. 2017.

PARADIS, S.; HARRAR, D. B.; LIN, Y.; KOON, A. C.; HAUSER, J. L.; GRIFFITH, E. C.; ZHU, L.; BRASS, L. F.; CHEN, C.; GREENBERG, M. E. An RNAi-based approach identifies molecules required for glutamatergic and GABAergic synapse development. Neuron, v. 53, n. 2, p. 217-32, 18 jan. 2007. Disponível em: <http://www.ncbi.nlm.nih.gov/pubmed/17224404>. Acesso em: 27 abr. 2018.

PARK, I.-H.; ARORA, N.; HUO, H.; MAHERALI, N.; AHFELDT, T.; SHIMAMURA, A.; LENSCH, M. W.; COWAN, C.; HOCHEDLINGER, K.; DALEY, G. Q. Disease-specific induced pluripotent stem cells. Cell, v. 134, n. 5, p. 877-86, 5 set. 2008. Disponível em: <http://www.ncbi.nlm.nih.gov/pubmed/18691744>. Acesso em: 13 nov. 2016.

PAŞCA, A. M.; SLOAN, S. A.; CLARKE, L. E.; TIAN, Y.; MAKINSON, C. D.; HUBER, N.; KIM, C. H.; PARK, J.-Y.; O'ROURKE, N. A.; NGUYEN, K. D.; SMITH, S. J.; HUGUENARD, J. R.; GESCHWIND, D. H.; BARRES, B. A.; PAŞCA, S. P. Functional cortical neurons and astrocytes from human pluripotent stem cells in 3D culture. Nature methods, v. 12, n. 7, p. 671-8, jul. 2015. Disponível em: <http://www.ncbi.nlm.nih.gov/pubmed/26005811>. Acesso em: 4 maio. 2017.

PASCOALINO, B. S.; COURTEMANCHE, G.; CORDEIRO, M. T.; GIL, L. H. V. G.; FREITAS-JUNIOR, L. Zika antiviral chemotherapy: identification of drugs and promising starting points for drug discovery from an FDA-approved library. F1000Research, v. 5, p. 2523, 14 out. 2016. Disponível em: <https://f1000research.com/articles/5-2523/v1>. Acesso em: 17 abr. 2018. 
PENKERT, R. R.; KALEJTA, R. F. Human embryonic stem cell lines model experimental human cytomegalovirus latency. mBio, v. 4, n. 3, p. e00298-13, 28 maio 2013. Disponível em: <http://www.ncbi.nlm.nih.gov/pubmed/23716573>. Acesso em: 8 maio. 2017.

PERERA-LECOIN, M.; MEERTENS, L.; CARNEC, X.; AMARA, A. Flavivirus Entry Receptors: An Update. Viruses, v. 6, n. 1, p. 69-88, 30 dez. 2013. Disponível em: <http://www.mdpi.com/1999-4915/6/1/69/>. Acesso em: 2 maio. 2017.

PERSAUD, M.; MARTINEZ-LOPEZ, A.; BUFFONE, C.; PORCELLI, S. A.; DIAZGRIFFERO, F. Infection by Zika viruses requires the transmembrane protein $A X L$, endocytosis and low pH. Virology, v. 518, p. 301-312, 1 maio 2018. Disponível em: <https://www.sciencedirect.com/science/article/pii/S0042682218300898?via\%3Dihub >. Acesso em: 10 abr. 2018.

QIAN, X.; NGUYEN, H. N. N.; SONG, M. M. M.; HADIONO, C.; OGDEN, S. C. C.; HAMMACK, C.; YAO, B.; HAMERSKY, G. R. R.; JACOB, F.; ZHONG, C.; YOON, K.; JEANG, W.; LIN, L.; LI, Y.; THAKOR, J.; BERG, D. A. A.; ZHANG, C.; KANG, E.; CHICKERING, M.; NAUEN, D.; HO, C.-Y.; WEN, Z.; CHRISTIAN, K. M. M.; SHI, P.Y.; MAHER, B. J. J.; WU, H.; JIN, P.; TANG, H.; SONG, H.; MING, G. Brain-RegionSpecific Organoids Using Mini-bioreactors for Modeling ZIKV Exposure. Cell, v. 165, n. 5, p. 1238-1254, 2016.

QUINN, D. P.; KOLAR, A.; WIGERIUS, M.; GOMM-KOLISKO, R. N.; ATWI, H.; FAWCETT, J. P.; KRUEGER, S. R. Pan-neurexin perturbation results in compromised synapse stability and a reduction in readily releasable synaptic vesicle pool size. Scientific reports, v. 7, p. 42920, 21 fev. 2017. Disponível em: <http://www.ncbi.nlm.nih.gov/pubmed/28220838>. Acesso em: 27 abr. 2018.

RAVICHANDRAN, K. S. Beginnings of a Good Apoptotic Meal: The Find-Me and EatMe Signaling Pathways. Immunity, v. 35, n. 4, p. 445-455, 2011. Disponível em: <http://www.sciencedirect.com/science/article/pii/S1074761311003645>. Acesso em: 2 maio. 2017.

RETALLACK, H.; DI LULLO, E.; ARIAS, C.; KNOPP, K. A.; LAURIE, M. T.; SANDOVAL-ESPINOSA, C.; MANCIA LEON, W. R.; KRENCIK, R.; ULLIAN, E. M.; SPATAZZA, J.; POLLEN, A. A.; MANDEL-BREHM, C.; NOWAKOWSKI, T. J.; KRIEGSTEIN, A. R.; DERISI, J. L. Zika virus cell tropism in the developing human brain and inhibition by azithromycin. Proceedings of the National Academy of Sciences of the United States of America, v. 113, n. 50, p. 14408-14413, 13 dez. 2016. Disponível em: <http://www.ncbi.nlm.nih.gov/pubmed/27911847>. Acesso em: 12 maio. 2017. 
RIBEIRO, L. F.; VERPOORT, B.; DE WIT, J. Trafficking mechanisms of synaptogenic cell adhesion molecules. Molecular and Cellular Neuroscience, n. January, p. 0-1, abr. 2018.2 Disponível em: <http://linkinghub.elsevier.com/retrieve/pii/S1044743118300381 >. Acesso em: 26 abr. 2018.

ROELANDT, P.; OBEID, S.; PAESHUYSE, J.; VANHOVE, J.; VAN LOMMEL, A.; NAHMIAS, Y.; NEVENS, F.; NEYTS, J.; VERFAILLIE, C. M. Human pluripotent stem cell-derived hepatocytes support complete replication of hepatitis $C$ virus. Journal of Hepatology, v. 57, n. 2, p. 246-251, 2012. Disponível em: <http://www.sciencedirect.com/science/article/pii/S0168827812002863>. Acesso em: 8 maio. 2017.

ROMERO-BREY, I.; BARTENSCHLAGER, R. Membranous replication factories induced by plus-strand RNA viruses. Viruses, v. 6, n. 7, p. 2826-57, 22 jul. 2014. Disponível em: <http://www.ncbi.nlm.nih.gov/pubmed/25054883>. Acesso em: 20 fev. 2017.

ROTHLIN, C. V; GHOSH, S.; ZUNIGA, E. I.; OLDSTONE, M. B. A.; LEMKE, G. TAM receptors are pleiotropic inhibitors of the innate immune response. Cell, v. 131, n. 6 , p. 1124-36, 14 dez. 2007. Disponível em: <http://www.ncbi.nlm.nih.gov/pubmed/18083102>. Acesso em: 17 abr. 2018.

RUSSO, F. B. Geração de células pluripotentes induzidas de pacientes com transtorno do espectro autista. p. 98, 2016.

RUSSO, F. B.; FREITAS, B. C.; PIGNATARI, G. C.; FERNANDES, I. R.; SEBAT, J.; MUOTRI, A. R.; BELTRÃO-BRAGA, P. C. B. Modeling the Interplay Between Neurons and Astrocytes in Autism Using Human Induced Pluripotent Stem Cells. Biological Psychiatry, v. 83, n. 7, p. 569-578, 2018. Disponível em: <https://www.sciencedirect.com/science/article/pii/S0006322317320097\#fig1>. Acesso em: 9 jan. 2018.

SACRAMENTO, C. Q.; DE MELO, G. R.; DE FREITAS, C. S.; ROCHA, N.; HOELZ, L. V. B.; MIRANDA, M.; FINTELMAN-RODRIGUES, N.; MARTTORELLI, A.; FERREIRA, A. C.; BARBOSA-LIMA, G.; ABRANTES, J. L.; VIEIRA, Y. R.; BASTOS, M. M.; DE MELLO VOLOTÃO, E.; NUNES, E. P.; TSCHOEKE, D. A.; LEOMIL, L.; LOIOLA, E. C.; TRINDADE, P.; REHEN, S. K.; BOZZA, F. A.; BOZZA, P. T.; BOECHAT, N.; THOMPSON, F. L.; DE FILIPPIS, A. M. B.; BRÜNING, K.; SOUZA, T. M. L. The clinically approved antiviral drug sofosbuvir inhibits Zika virus replication. Scientific reports, v. 7, p. 40920, 18 jan. 2017. Disponível em: <http://www.ncbi.nlm.nih.gov/pubmed/28098253>. Acesso em: 12 maio. 2017. 
SCHLAEGER, T. M.; DAHERON, L.; BRICKLER, T. R.; ENTWISLE, S.; CHAN, K.; CIANCI, A.; DEVINE, A.; ETTENGER, A.; FITZGERALD, K.; GODFREY, M.; GUPTA, D.; MCPHERSON, J.; MALWADKAR, P.; GUPTA, M.; BELL, B.; DOI, A.; JUNG, N.; LI, X.; LYNES, M. S.; BROOKES, E.; CHERRY, A. B. C.; DEMIRBAS, D.; TSANKOV, A. M.; ZON, L. I.; RUBIN, L. L.; FEINBERG, A. P.; MEISSNER, A.; COWAN, C. A.; DALEY, G. Q. A comparison of non-integrating reprogramming methods. Nat Biotech, v. 33, n. 1, p. 58-63, jan. 2015. Disponível em: <http://dx.doi.org/10.1038/nbt.3070>.

SCHWARTZ, R. E.; TREHAN, K.; ANDRUS, L.; SHEAHAN, T. P.; PLOSS, A.; DUNCAN, S. A.; RICE, C. M.; BHATIA, S. N. Modeling hepatitis $C$ virus infection using human induced pluripotent stem cells. Proceedings of the National Academy of Sciences of the United States of America, v. 109, n. 7, p. 2544-8, 14 fev. 2012. Disponível em: <http://www.ncbi.nlm.nih.gov/pubmed/22308485>. Acesso em: 5 maio. 2017.

SHI, P.-Y.; KAUfFMAN, E. B.; REN, P.; FELTON, A.; TAI, J. H.; DUPUIS, A. P.; JONES, S. A.; NGO, K. A.; NICHOLAS, D. C.; MAFFEI, J.; EBEL, G. D.; BERNARD, K. A.; KRAMER, L. D. High-Throughput Detection of West Nile Virus RNA. Journal of Clinical Microbiology, v. 39, n. 4, p. 1264-1271, 1 abr. 2001. Disponível em: <http://www.ncbi.nlm.nih.gov/pubmed/11283039>. Acesso em: 21 fev. 2017.

SHIRYAEV, S. A.; MESCI, P.; PINTO, A.; FERNANDES, I.; SHEETS, N.; SHRESTA, S.; FARHY, C.; HUANG, C.-T.; STRONGIN, A. Y.; MUOTRI, A. R.; TERSKIKH, A. V. Repurposing of the anti-malaria drug chloroquine for Zika Virus treatment and prophylaxis. Scientific Reports, v. 7, n. 1, p. 15771, 17 dez. 2017. Disponível em: <http://www.nature.com/articles/s41598-017-15467-6>. Acesso em: 17 abr. 2018.

SIMPSON, D. Zika virus infection in man. Transactions of the Royal Society of Tropical Medicine and Hygiene, v. july, n. 58, p. 335-338, 1964.

STERNECKERT, J. L.; REINHARDT, P.; SCHOLER, H. R. Investigating human disease using stem cell models. Nat Rev Genet, v. 15, n. 9, p. 625-639, set. 2014. Disponível em: <http://dx.doi.org/10.1038/nrg3764>.

SULKOWSKI, M. S.; GARDINER, D. F.; RODRIGUEZ-TORRES, M.; REDDY, K. R.; HASSANEIN, T.; JACOBSON, I.; LAWITZ, E.; LOK, A. S.; HINESTROSA, F.; THULUVATH, P. J.; SCHWARTZ, H.; NELSON, D. R.; EVERSON, G. T.; ELEY, T.; WIND-ROTOLO, M.; HUANG, S.-P.; GAO, M.; HERNANDEZ, D.; MCPHEE, F.; SHERMAN, D.; HINDES, R.; SYMONDS, W.; PASQUINELLI, C.; GRASELA, D. M. Daclatasvir plus Sofosbuvir for Previously Treated or Untreated Chronic HCV Infection. New England Journal of Medicine, v. 370, n. 3, p. 211-221, 16 jan. 2014. Disponível em: <http://www.nejm.org/doi/10.1056/NEJMoa1306218>. Acesso em: 14 maio. 2017. 
TABATA, T.; PETITT, M.; PUERTA-GUARDO, H.; MICHLMAYR, D.; WANG, C.; FANG-HOOVER, J.; HARRIS, E.; PEREIRA, L. Zika Virus Targets Different Primary Human Placental Cells, Suggesting Two Routes for Vertical Transmission. Cell Host \& Microbe, v. 20, n. 2, p. 155-166, 2016.

TAKAHASHI, K.; TANABE, K.; OHNUKI, M.; NARITA, M.; ICHISAKA, T.; TOMODA, K.; YAMANAKA, S. Induction of Pluripotent Stem Cells from Adult Human Fibroblasts by Defined Factors. Cell, v. 131, n. 5, p. 861-872, 2007. Disponível em: <http://www.sciencedirect.com/science/article/pii/S0092867407014717>. Acesso em: 4 maio. 2017.

TAKAHASHI, K.; YAMANAKA, S. Induction of Pluripotent Stem Cells from Mouse Embryonic and Adult Fibroblast Cultures by Defined Factors. Cell, v. 126, n. 4, p. 663676, 2006.

TANG, H.; HAMMACK, C.; OGDEN, S. C. C.; WEN, Z.; QIAN, X.; LI, Y.; YAO, B.; SHIN, J.; ZHANG, F.; LEE, E. M. M.; CHRISTIAN, K. M. M.; DIDIER, R. A. A.; JIN, P.; SONG, H.; MING, G. Zika Virus Infects Human Cortical Neural Progenitors and Attenuates Their Growth. Cell Stem Cell, v. 18, n. 5, p. 587-590, maio 2016. Disponível em: <http://linkinghub.elsevier.com/retrieve/pii/S1934590916001065>. Acesso em: 20 fev. 2017.

TEISSIER, N.; FALLET-BIANCO, C.; DELEZOIDE, A.-L.; LAQUERRIÈRE, A.; MARCORELLES, P.; KHUNG-SAVATOVSKY, S.; NARDELLI, J.; CIPRIANI, S.; CSABA, Z.; PICONE, O.; GOLDEN, J. A.; VAN DEN ABBEELE, T.; GRESSENS, P.; ADLE-BIASSETTE, H. Cytomegalovirus-Induced Brain Malformations in Fetuses. Journal of Neuropathology \& Experimental Neurology, v. 73, n. 2, p. 143-158, fev. 2014. Disponível em: <https://academic.oup.com/jnen/articlelookup/doi/10.1097/NEN.0000000000000038>. Acesso em: 20 fev. 2017.

TORRES, V. I.; VALLEJO, D.; INESTROSA, N. C. Emerging Synaptic Molecules as Candidates in the Etiology of Neurological Disorders. Neural plasticity, v. 2017, p. 8081758, 2017. Disponível em: <http://www.ncbi.nlm.nih.gov/pubmed/28331639>. Acesso em: 27 abr. 2018.

TOUSSAINT-MILLER, K. A.; ANDRES, J. Treatment Considerations for Unique Patient Populations With HCV Genotype 1 Infection. Annals of Pharmacotherapy, v. 49, n. 9, p. 1015-1030, set. 2015. Disponível em: <http://journals.sagepub.com/doi/10.1177/1060028015592015>. Acesso em: 29 maio. 2017.

TREVISAN, M.; SINIGAGLIA, A.; DESOLE, G.; BERTO, A.; PACENTI, M.; PALÙ, G.; BARZON, L. Modeling Viral Infectious Diseases and Development of Antiviral 
Therapies Using Human Induced Pluripotent Stem Cell-Derived Systems. Viruses, v. 7, n. 7, p. 3835-3856, 13 jul. 2015. Disponível em: <http://www.ncbi.nlm.nih.gov/pubmed/26184286>. Acesso em: 14 abr. 2017.

VESSONI, A. T.; HERAI, R. H.; KARPIAK, J. V.; LEAL, A. M. S.; TRUJILLO, C. A.; QUINET, A.; AGNEZ LIMA, L. F.; MENCK, C. F. M.; MUOTRI, A. R. Cockayne syndrome-derived neurons display reduced synapse density and altered neural network synchrony. Human Molecular Genetics, v. 25, n. 7, p. 1271-1280, 1 abr. 2016. Disponível em: <https://academic.oup.com/hmg/articlelookup/doi/10.1093/hmg/ddw008>. Acesso em: 20 fev. 2017.

WANG, W. K.; LEE, C. N.; KAO, C. L.; LIN, Y. L.; KING, C. C. Quantitative competitive reverse transcription-PCR for quantification of dengue virus RNA. Journal of clinical microbiology, v. 38, n. 9, p. 3306-10, set. 2000. Disponível em: <http://www.ncbi.nlm.nih.gov/pubmed/10970375>. Acesso em: 21 fev. 2017.

WEINBREN, M. P.; WILLIAMS, M. C. Zika virus: further isolations in the Zika area, and some studies on the strains isolated. Transactions of the Royal Society of Tropical Medicine and Hygiene, v. 52, n. 3, p. 263-8, 1958.

WELLS, M. F.; SALICK, M. R.; WISKOW, O.; HO, D. J.; WORRINGER, K. A.; IHRY, R. J.; KOMMINENI, S.; BILICAN, B.; KLIM, J. R.; HILL, E. J.; KANE, L. T.; YE, C.; KAYKAS, A.; EGGAN, K. Genetic Ablation of AXL Does Not Protect Human Neural Progenitor Cells and Cerebral Organoids from Zika Virus Infection. Cell stem cell, v. 19, n. 6, p. 703-708, 1 dez. 2016. Disponível em: <http://www.ncbi.nlm.nih.gov/pubmed/27912091>. Acesso em: 18 abr. 2018.

WHO. WHO Director-General summarizes the outcome of the Emergency Committee regarding clusters of microcephaly and Guillain-Barré syndrome. [s.l.] World Health Organization, 2016. . Disponível em: <http://www.who.int/mediacentre/news/statements/2016/emergency-committee-zikamicrocephaly/en/>. Acesso em: 2 jul. 2017.

WU, X.; ROBOTHAM, J. M.; LEE, E.; DALTON, S.; KNETEMAN, N. M.; GILBERT, D. M.; TANG, H. Productive Hepatitis C Virus Infection of Stem Cell-Derived Hepatocytes Reveals a Critical Transition to Viral Permissiveness during Differentiation. PLoS Pathogens, v. 8, n. 4, p. e1002617, 5 abr. 2012. Disponível em: <http://dx.plos.org/10.1371/journal.ppat.1002617>. Acesso em: 8 maio. 2017.

XU, M.; LEE, E. M.; WEN, Z.; CHENG, Y.; HUANG, W.-K.; QIAN, X.; TCW, J.; KOUZNETSOVA, J.; OGDEN, S. C.; HAMMACK, C.; JACOB, F.; NGUYEN, H. N.; ITKIN, M.; HANNA, C.; SHINN, P.; ALLEN, C.; MICHAEL, S. G.; SIMEONOV, A.; HUANG, W.; CHRISTIAN, K. M.; GOATE, A.; BRENNAND, K. J.; HUANG, R.; XIA, M.; 
MING, G.; ZHENG, W.; SONG, H.; TANG, H. Identification of small-molecule inhibitors of Zika virus infection and induced neural cell death via a drug repurposing screen. Nat Med, v. 22, n. 10, p. 1101-1107, out. 2016. Disponível em: <http://dx.doi.org/10.1038/nm.4184>.

ZHANG, F.; HAMMACK, C.; OGDEN, S. C.; CHENG, Y.; LEE, E. M.; WEN, Z.; QIAN, X.; NGUYEN, H. N.; LI, Y.; YAO, B.; XU, M.; XU, T.; CHEN, L.; WANG, Z.; FENG, H.; HUANG, W.-K.; YOON, K.; SHAN, C.; HUANG, L.; QIN, Z.; CHRISTIAN, K. M.; SHI, P.-Y.; XU, M.; XIA, M.; ZHENG, W.; WU, H.; SONG, H.; TANG, H.; MING, G.-L.; JIN, P. Molecular signatures associated with ZIKV exposure in human cortical neural progenitors. Nucleic Acids Research, v. 44, n. 18, p. 8610-8620, 14 out. 2016. Disponível em: $<$ https://academic.oup.com/nar/articlelookup/doi/10.1093/nar/gkw765>. Acesso em: 9 maio. 2017.

ZHOU, Q.; ZHOU, P.; WANG, A. L.; WU, D.; ZHAO, M.; SÜDHOF, T. C.; BRUNGER, A. T. The primed SNARE-complexin-synaptotagmin complex for neuronal exocytosis. Nature, v. 548, n. 7668, p. 420-425, 2017. Disponível em: <http://www.ncbi.nlm.nih.gov/pubmed/28813412>. Acesso em: 26 abr. 2018.

ZOGHBI, H. Y. Postnatal neurodevelopmental disorders: meeting at the synapse? Science (New York, N.Y.), v. 302, n. 5646, p. 826-30, 31 out. 2003. Disponível em: <http://www.ncbi.nlm.nih.gov/pubmed/14593168>. Acesso em: 26 abr. 2018. 


\section{APÊNDICES}

A - CUGOLA, F. R.; FERNANDES, I. R.; RUSSO, F. B.; FREITAS, B. C.; DIAS, J. L. M.; GUIMARAES, K. P.; BENAZZATO, C.; ALMEIDA, N.; PIGNATARI, G. C.; ROMERO, S.; POLONIO, C. M.; CUNHA, I.; FREITAS, C. L.; BRANDAO, W. N.; ROSSATO, C.; ANDRADE, D. G.; FARIA, D. de P.; GARCEZ, A. T.; BUCHPIGEL, C. A.; BRACONI, C. T.; MENDES, E.; SALL, A. A.; ZANOTTO, P. M. de A.; PERON, J. P. S.; MUOTRI, A. R.; BELTRAO-BRAGA, P. C. B. The Brazilian Zika Virus Strain Causes Birth Defects in Experimental Models. Nature, v. 534, n. 7606, p. 267-271, jun. 2016.

B - MESCI, P.; MACIA, A.; MOORE, S. M.; SHIRYAEV, S. A.; PINTO, A.; HUANG, C.T.; TEJWANI, L.; FERNANDES, I. R.; SUAREZ, N. A.; KOLAR, M. J.; MONTEFUSCO, S.; ROSENBERG, S. C.; HERAI, R. H.; CUGOLA, F. R.; RUSSO, F. B.; SHEETS, N.; SAGHATELIAN, A.; SHRESTA, S.; MOMPER, J. D.; SIQUEIRA-NETO, J. L.; CORBETT, K. D.; BELTRÃO-BRAGA, P. C. B.; TERSKIKH, A. V.; MUOTRI, A. R. Blocking Zika virus vertical transmission. Scientific Reports, v. 8, n. 1, p. 1218, 19 dez. 2018.

C - FREIRE, C. C. M.; PALMISANO, G.; BRACONI, C.T.; CUGOLA, F.R.; RUSSO, F.B.; BELTRÃO-BRAGA, P. C. B.; IAMARINO, A.; NETO, D. F. L.; SALL, A. A.; ROSAFERNANDES, L.; LARSEN, M. R.; ZANOTTO, P. M. de A. NS1 codon usage adaptation to humans in pandemic Zika virus. Mem Inst Oswaldo Cruz, v. 113, n. 5, e170385, 2018. 


\section{The Brazilian Zika virus strain causes birth defects in experimental models}

Fernanda R. Cugola ${ }^{1 *}$, Isabella R. Fernandes ${ }^{1,2 *}$, Fabiele B. Russo ${ }^{1,3 *}$, Beatriz C. Freitas ${ }^{2}$, João L. M. Dias ${ }^{1}$, Katia P. Guimarães ${ }^{1}$, Cecília Benazzato $^{1}$, Nathalia Almeida ${ }^{1}$, Graciela C. Pignatari ${ }^{1,3}$, Sarah Romero ${ }^{2}$, Carolina M. Polonio ${ }^{4}$, Isabela Cunha ${ }^{4}$, Carla L. Freitas ${ }^{4}$, Wesley N. Brandão ${ }^{4}$, Cristiano Rossato ${ }^{4}$, David G. Andrade ${ }^{4}$, Daniele de P. Faria ${ }^{5}$, Alexandre T. Garcez ${ }^{5}$, Carlos A. Buchpigel ${ }^{5}$, Carla T. Braconi ${ }^{6}$, Erica Mendes ${ }^{6}$, Amadou A. Sall ${ }^{7}$, Paolo M. de A. Zanotto ${ }^{6}$, Jean Pierre S. Peron ${ }^{4}$, Alysson R. Muotri ${ }^{2}$ \& Patricia C. B. Beltrão-Braga ${ }^{1,8}$

Zika virus (ZIKV) is an arbovirus belonging to the genus Flavivirus (family Flaviviridae) and was first described in 1947 in Uganda following blood analyses of sentinel rhesus monkeys ${ }^{1}$. Until the twentieth century, the African and Asian lineages of the virus did not cause meaningful infections in humans. However, in 2007, vectored by Aedes aegypti mosquitoes, ZIKV caused the first noteworthy epidemic on Yap Island in Micronesia ${ }^{2}$. Patients experienced fever, skin rash, arthralgia and conjunctivitis ${ }^{2}$. From 2013 to 2015, the Asian lineage of the virus caused further massive outbreaks in New Caledonia and French Polynesia. In 2013, ZIKV reached Brazil, later spreading to other countries in South and Central America ${ }^{3}$. In Brazil, the virus has been linked to congenital malformations, including microcephaly and other severe neurological diseases, such as Guillain-Barré syndrome ${ }^{4,5}$. Despite clinical evidence, direct experimental evidence showing that the Brazilian ZIKV $\left(\mathrm{ZIKV}^{\mathrm{BR}}\right)$ strain causes birth defects remains absent ${ }^{6}$. Here we demonstrate that $\mathrm{ZIKV}^{\mathrm{BR}}$ infects fetuses, causing intrauterine growth restriction, including signs of microcephaly, in mice. Moreover, the virus infects human cortical progenitor cells in vitro, leading to an increase in cell death. We also report that the infection of human brain organoids results in a reduction of proliferative zones and disrupted cortical layers. These results indicate that $\mathrm{ZIKV}^{\mathrm{BR}}$ crosses the placenta and causes microcephaly by targeting cortical progenitor cells, inducing cell death by apoptosis and autophagy, and impairing neurodevelopment. Our data reinforce the growing body of evidence linking the $\mathrm{ZIKV}^{\mathrm{BR}}$ outbreak to the alarming number of cases of congenital brain malformations. Our model can be used to determine the efficiency of therapeutic approaches to counteracting the harmful impact of $\mathrm{ZIKV}^{\mathrm{BR}}$ in human neurodevelopment.

The recent increase in microcephaly cases in Brazil has been associated with the outbreak of Zika virus $(\mathrm{ZIKV})^{7}$, originating from an Asian-lineage strain that can be spread by Ae. aegypti mosquitoes ${ }^{8}$. The Brazilian ZIKV $\left(\mathrm{ZIKV}^{\mathrm{BR}}\right)$ has been detected in the placenta and amniotic fluid of two women with microcephalic fetuses ${ }^{9-11}$ and in the blood of microcephalic newborns ${ }^{10,12}$, suggesting that the virus can cross the placental membrane. The virus has also been identified in the brains and retinas of microcephalic fetuses ${ }^{11-13}$. However, there is no direct evidence of the mechanism by which $\mathrm{ZIKV}^{\mathrm{BR}}$ might cause brain malformations. A previous study revealed that the African ZIKV $\left(\mathrm{ZIKV} \mathrm{AF}^{\mathrm{AF}}\right.$, strain MR-766) has the ability to infect human skin cells ${ }^{14}$. Neurons and astrocytes in the mouse brain could also be infected, inducing hippocampal degeneration and necrosis of pyriform cells
7 days post-infection ${ }^{15}$. More recently, $\mathrm{ZIKV}^{\mathrm{AF}}$ was also shown to infect human pluripotent stem cell (hPSC)-derived neural progenitor cells (NPCs) in vitro, which induced apoptotic cell death ${ }^{16}$. These studies were performed using the MR-766 ZIKV $\mathrm{IF}^{\mathrm{AF}}$ strain isolated in Uganda in 1947, which shares $87-90 \%$ sequence similarity with the Polynesian and Brazilian isolates ${ }^{3,17}$. Nevertheless, because severe congenital malformations were not reported for African isolates, there is a need to study the association of ZIKV with microcephaly and birth defects with isolates from affected localities, such as the ZIKV ${ }^{\mathrm{BR}}$ strain. Therefore, there is an urgent need to develop model systems to determine the relationship between infection with the $\mathrm{ZIKV}{ }^{\mathrm{BR}}$ strain and birth defects.

We used $\mathrm{ZIKV} \mathrm{BR}^{\mathrm{BR}}$ isolated from a febrile case in the state of Paraiba, in the northeast of Brazil in 2015 (see Methods). To evaluate the causal relationship between $\mathrm{ZIKV}^{\mathrm{BR}}$ and birth defects, including brain malformation during development, we first used a murine experimental model in which SJL and C57BL/6 pregnant mice were infected with ZIKV ${ }^{\mathrm{BR}}$, evaluating newborns immediately after birth (Extended Data Fig. 1a). Notably, similar to $\mathrm{ZIKV}^{\mathrm{BR}}$-infected human newborns ${ }^{18,19}$, pups born from the SJL ZIKV ${ }^{\mathrm{BR}}$-infected pregnant females displayed clear evidence of whole-body growth delay or intrauterine growth restriction (IUGR) ${ }^{20}$ compared to pups born from the mock-infected controls (Fig. 1a, b). Using a qPCR assay, we confirmed the presence of $\mathrm{ZIKV}^{\mathrm{BR}}$ genomic RNA in several tissues of newborn animals, observing significantly more viral RNA in the brain, confirming the neurotropic nature of the virus (Fig. 1c).

Microcephaly is perhaps the most striking of the birth defects reported in $\mathrm{ZIKV}^{\mathrm{BR}}$-infected newborns ${ }^{4,18,19}$. Mouse models often fail to reproduce the severely reduced brain size and pathological alterations found in human patients ${ }^{21,22}$, probably owing to differences in gestation time and brain development between the two species. Nevertheless, upon close inspection of the $\mathrm{ZIKV}^{\mathrm{BR}}$-infected mouse brains, we noticed cortical malformations in the surviving animals, with reduced cell number and cortical layer thickness, signs associated with microcephaly in humans (Fig. 1d-f). At a cellular level, the neurons in the cortex, thalamus and hypothalamus displayed a 'vacuolar nuclei' appearance. This morphology was characterized by central emptiness and marginalized chromatin pattern with nuclear debris, suggesting ongoing cellular death (Fig. $1 \mathrm{~d}$ and Extended Data Fig. 2). In addition, we also noticed apparent ocular abnormalities, reminiscent of that observed in human patients ${ }^{23}$ (Fig. 1g). Thus, SJL infected pups presented congenital malformations with similarities to those in $\mathrm{ZIKV}^{\mathrm{BR}}$-infected human newborns. While the impact of $\mathrm{ZIKV}^{\mathrm{BR}}$

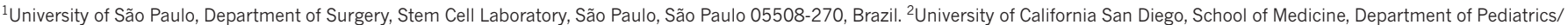

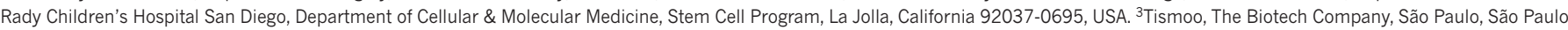

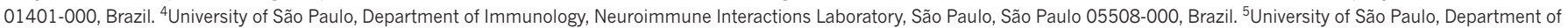

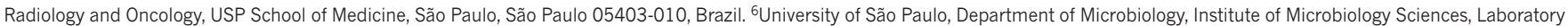
of Molecular Evolution and Bioinformatics, São Paulo, São Paulo 05508-000, Brazil. ${ }^{7}$ Institute Pasteur in Dakar, Dakar 220, Sénégal. ${ }^{8}$ University of São Paulo, School of Arts, Sciences and Humanities, Department of Obstetrics, São Paulo, São Paulo 03828-000, Brazil.

*These authors contributed equally to this work. 

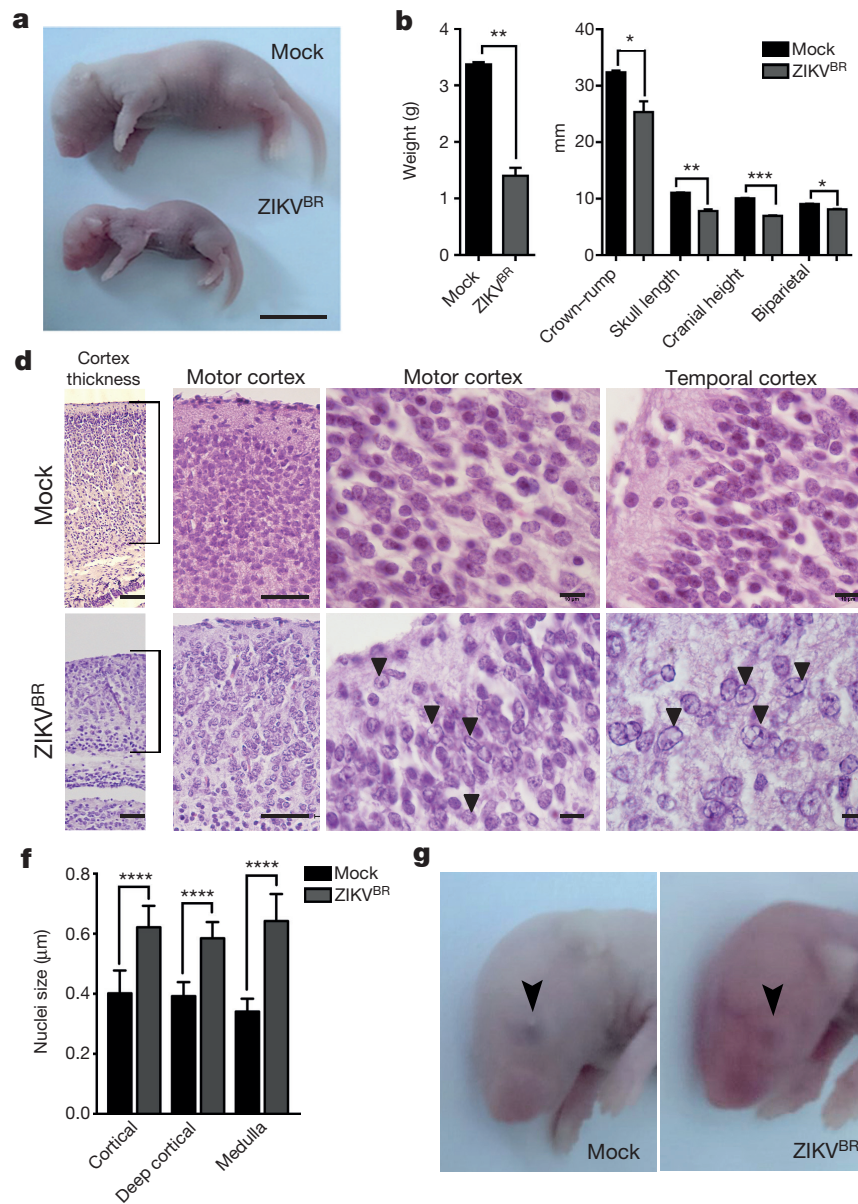

g
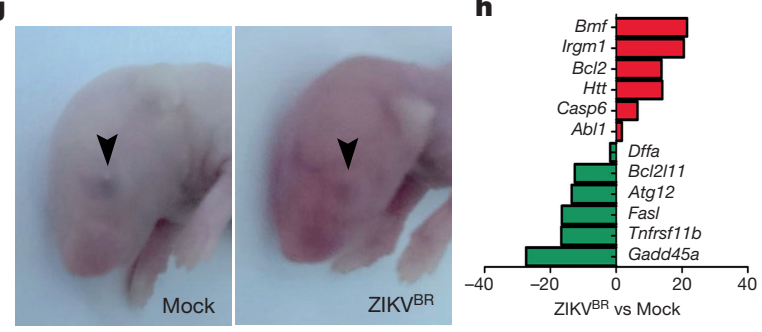

Figure $1 \mid \mathrm{ZIKV}^{\mathrm{BR}}$ infection in SJL mice. a, SJL pups born with IUGR. Scale bar, $1 \mathrm{~cm}$. b. Total body weight, crown-rump and skull measurements in pups born from infected animals ( $n=6$ pups, comprising 3 mice from 2 separate litters; error bars, s.e.m.; $t$-test, $* * P<0.01)$. c, ZIKV ${ }^{\mathrm{BR}}$ RNA detected in SJL pup tissues ( $n=6$ pups, comprising 3 mice from 2 separate litters; error bars, s.e.m.; $t$-test). d, Histopathological aspect of the cortical organization (brackets) in infected brains, including intranuclear vacuoles, and 'empty' nuclei aspect with chromatin margination in neurons (arrowheads). Scale bar, $100 \mu \mathrm{m}$ (left panels), $50 \mu \mathrm{m}$ (middle panels) and $10 \mu \mathrm{m}$ (right panels). e, $\mathrm{ZIKV}^{\mathrm{BR}}$-infected brains displayed a reduced cortical layer thickness ( $n=6$ pups, comprising 3 mice from 2 separate litters; error bars, s.e.m.; $t$-test, $* * * P<0.001)$. Infected brains have fewer cells per layer ( $n=6$ pups, comprising 3 mice from 2 separate litters; error bars, s.e.m.; $t$-test, $* * P<0.1)$. f, $\mathrm{ZIKV}^{\mathrm{BR}}$-infected cortical neurons have pronounced nuclei (diameter) (cortical, $n=31$; deep cortical, $n=21$ and medulla, $n=41$ nuclei; error bars, s.e.m.; two-way ANOVA, $* * * * P<0.001$ ). g, Ocular malformations (arrow) in the $\mathrm{ZIKV}^{\mathrm{BR}}$ infected pups. h, Cell death gene expression signature in the brains of $\mathrm{ZIKV}^{\mathrm{BR}}$-infected pups ( $n=2$ mice per group; threshold $=$ twofold).

important family of receptors used for cell invasion by the Dengue virus and ZIKV, and AXL has been recently proposed as a candidate receptor for ZIKV infection during neurogenesis ${ }^{14,24}$. Mock-infected NPCs expressed higher levels of AXL when compared to mock-infected neurons (Fig. 2a). However, no significant changes in expression levels were observed upon ZIKV infection in NPCs (Fig. 2b). We then investigated the impact of $\mathrm{ZIKV}^{\mathrm{BR}}$ and $\mathrm{ZIKV}^{\mathrm{AF}}$ infection in NPCs and neurons. After infection using a viral multiplicity of infection (MOI) of $10, \mathrm{ZIKV}^{\mathrm{BR}}$ particles were detected inside the NPCs and neurons at several stages of viral assembly using transmission electron microscopy (Fig. 2c). Immunostaining performed on NPCs and neurons at both an MOI of 10 and an MOI of 1 revealed production of viral protein aggregates (Fig. 2d and Extended Data Fig. 3b, c). With an MOI of 10, the amount of ZIKV ${ }^{\mathrm{BR}}$ particles in the NPC and neuron culture supernatant increased over time, suggesting the efficient production of infectious viral particles (Fig. 2e, f). With an MOI of 1, NPCs, but not neurons, continued to produce $\mathrm{ZIKV}^{\mathrm{BR}} \mathrm{RNA}$ in the culture supernatant (Extended Data Fig. 3d, e). After 96 h post-infection, we observed significant cell death in NPC cultures using fluorescence-activated cell (FAC) analyses. We quantified cell death over time in NPC cultures and detected an increase in the number of apoptotic/necrotic cells both in the $\mathrm{ZIKV}^{\mathrm{BR}}$ - and $\mathrm{ZIKV}{ }^{\mathrm{AF}}$-treated cultures compared to the 
a
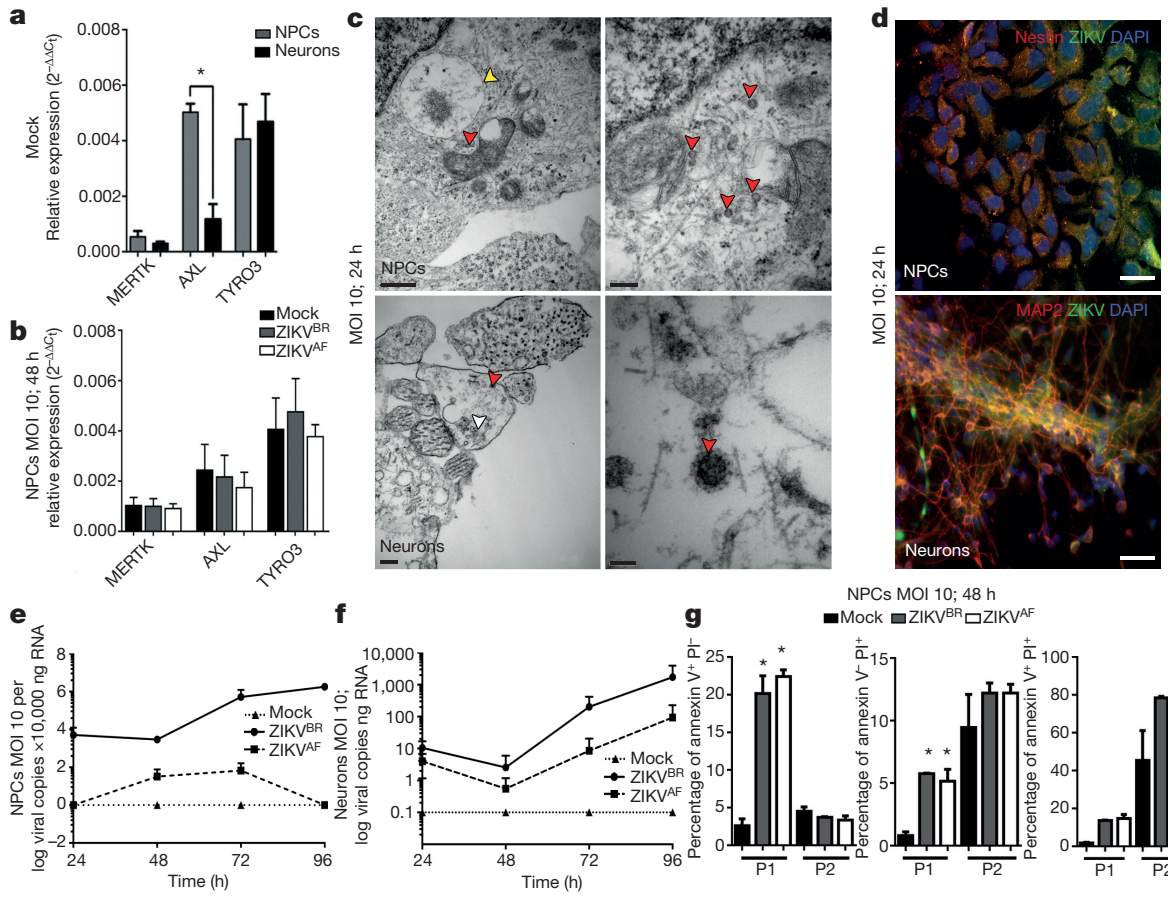

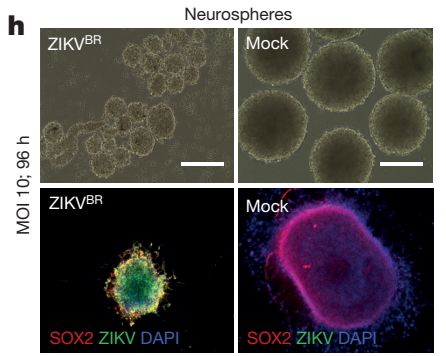

Figure 2 ZIKV infection in vitro. a, Relative expression of TAM receptors $(n=2$ technical replicates from two pooled different donors; error bars, s.e.m.; $t$-test; $* * * P<0.01)$. b, Expression of TAM receptors in NPCs after ZIKV ${ }^{\mathrm{BR}}$ infection $(\mathrm{MOI}=10)$ at $48 \mathrm{~h}$ post-infection ( $n=2$ technical replicates from two pooled different donors; error bars, s.e.m.; one-way ANOVA, $P>0.05)$. c, TEM detection of $\mathrm{ZIKV}{ }^{\mathrm{BR}}$ viral particles $24 \mathrm{~h}$ post-infection at MOI $=10$ (red arrowheads) inside NPCs (top panels) and neurons (bottom panels). Yellow arrowheads, viral factories; white arrowheads, immature viral particles. Scale bars, $0.5 \mu \mathrm{m}$ (top left); $200 \mathrm{~nm}$ (top right); $0.2 \mu \mathrm{m}$ (bottom left); $50 \mathrm{~nm}$ (bottom right). d, Immunofluorescence revealed susceptibility to infection in NPC and neurons with the $\mathrm{ZIKV}^{\mathrm{BR}}(\mathrm{MOI}=10)$ at $24 \mathrm{~h}$ post-infection. Scale bar, $25 \mu \mathrm{m}$. e, $\mathrm{ZIKV}^{\mathrm{BR}}$ replication dynamics in $\mathrm{NPCs}(\mathrm{MOI}=10$;

mock-infected cultures at an MOI of 10 (Fig. 2g), but not at an MOI of 1 during the same time frame (Extended Data Fig. 3f). No difference in neuronal cell death was observed between the two ZIKV strains at an MOI of 10 and an MOI of 1 (Extended Data Fig. 3g, h).

Next, we challenged two three-dimensional neural cell culture systems, neurospheres and cerebral organoids, with $\mathrm{ZIKV}^{\mathrm{BR}}$ and $\mathrm{ZIKV}^{\mathrm{AF}}$. We generated neurospheres by growing human NPCs in suspension. While the mock-infected control neurospheres continued to grow over time, the $\mathrm{ZIKV}^{\mathrm{BR}}$-infected neurospheres (MOI of 10) displayed evident morphological abnormalities with signs of cell death (Fig. 2h). The sizes of the neurospheres infected with $\mathrm{ZIKV}{ }^{\mathrm{BR}}$ were significantly smaller than the mock-control and $\mathrm{ZIKV}^{\mathrm{AF}}$-infected at $96 \mathrm{~h}$ post-infection (Fig. 2i). A less dramatic effect is observed at an MOI of 1 , where both $\mathrm{ZIKV}{ }^{\mathrm{BR}}$ and $\mathrm{ZIKV}{ }^{\mathrm{AF}}$ infection reduced the size of the neurospheres compared to mock-infected controls (Extended Data Fig. 4a, b). These observations were paired with increased $\mathrm{ZIKV}{ }^{\mathrm{BR}}$ replication in these cultures at both MOIs of 10 and 1 (Fig. $2 \mathrm{j}$ and Extended Data Fig. 4c). These results suggest that $\mathrm{ZIKV}^{\mathrm{BR}}$ induces cell death in human NPCs, impairing the growth and morphogenesis of healthy neurospheres (Extended Data Fig. 4d-f).

The majority of the described cases of $\mathrm{ZIKV}^{\mathrm{BR}}$-infected newborns $(95 \%)$ had malformations of cortical development ${ }^{4}$. Thus, we also used brain organoids generated from hPSCs and human embryonic stem cells, to evaluate the impact of $\mathrm{ZIKV}^{\mathrm{BR}}$ on human cortical development. In the following experiments, alongside the $\mathrm{ZIKV}^{\mathrm{AF}}$ and mock infection, we added the Yellow Fever virus (YFV), a slow replicating attenuated live-vaccine Flavivirus that has a low risk of causing neuropathy. Cerebral organoids are three-dimensional, self-organized, stem-cell-derived models that recapitulate the first trimester of human neurodevelopment, including the molecular and cellular architecture reminiscent of the fetal cortex ${ }^{25}$. Organoids show some degree of lamination and resembled the human neocortex in terms of the spatial relationships of the progenitor populations, defined here as a proliferative ventricular zone, post-migratory neurons in cortical plate and a marginal zone (Fig. 3a-c). We infected organoids with $\mathrm{ZIKV}^{\mathrm{BR}}, \mathrm{ZIKV}^{\mathrm{AF}}$ and YFV 

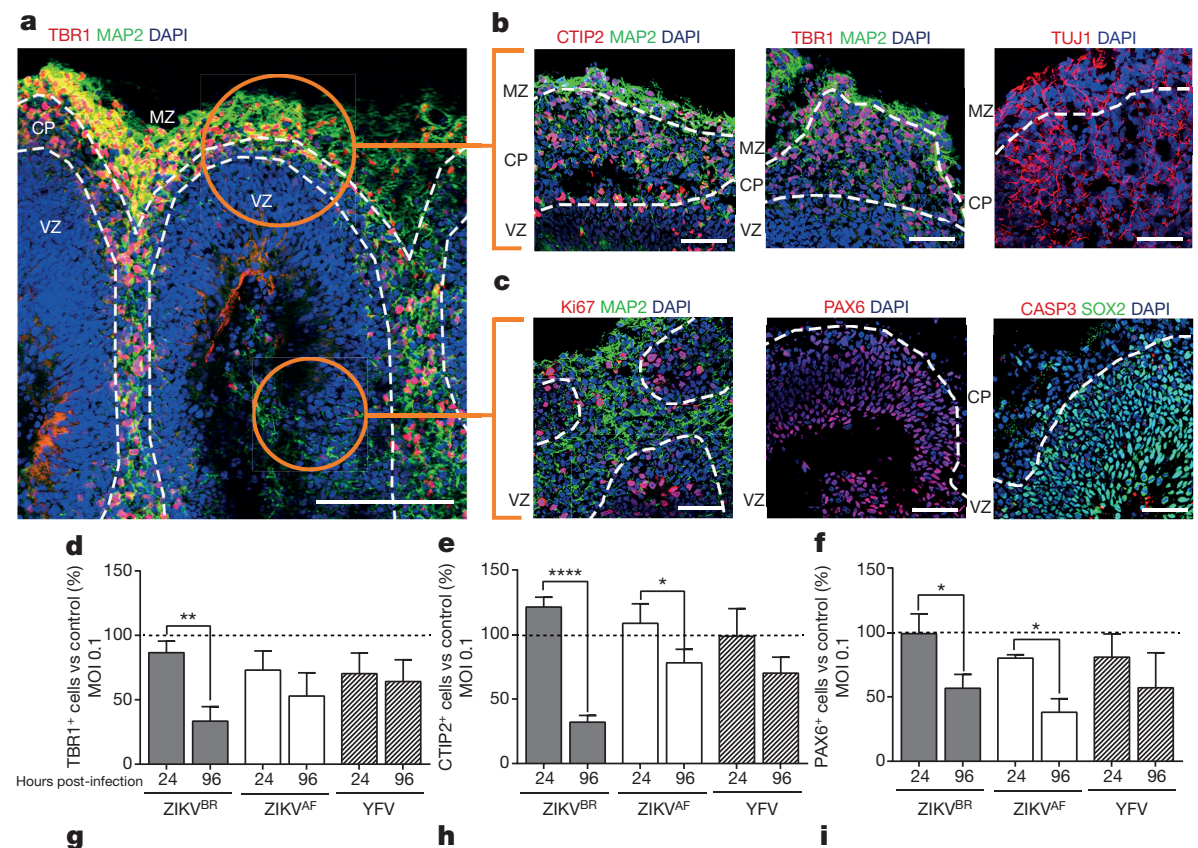

c
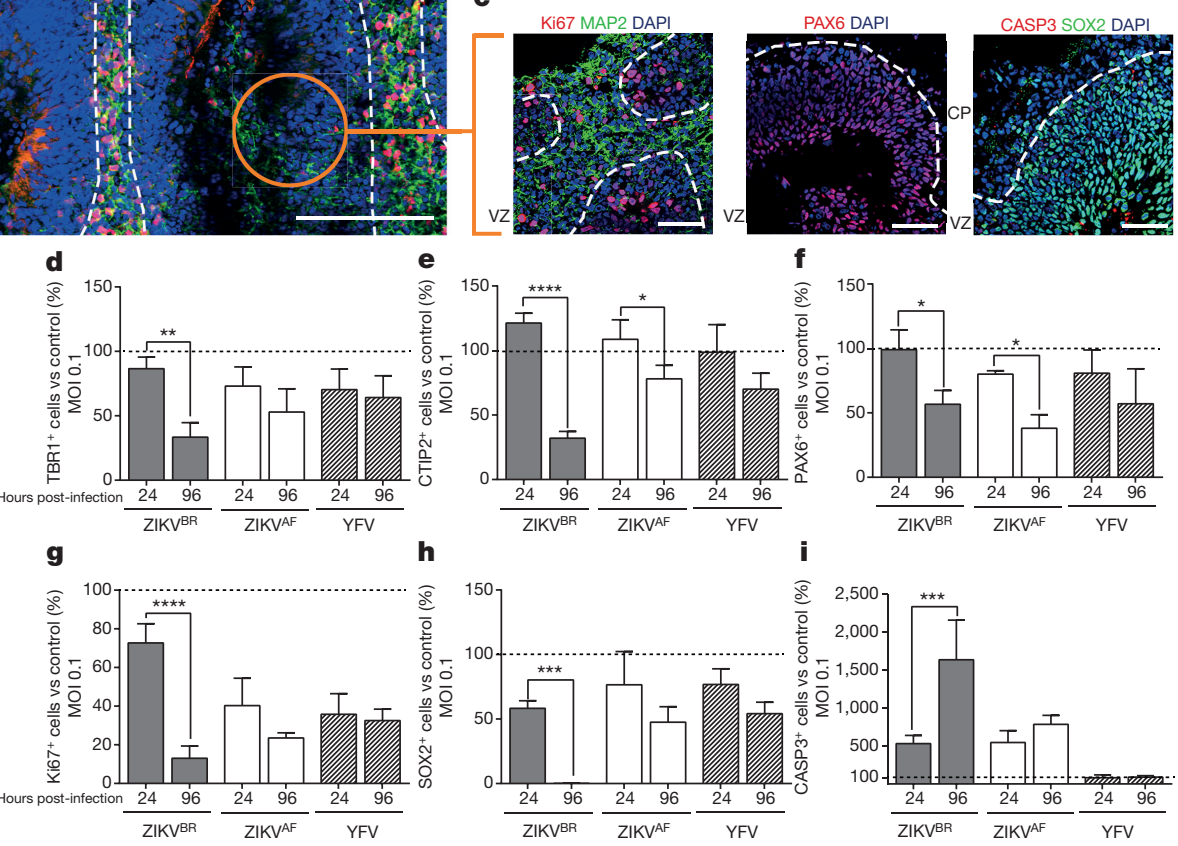

Figure 3 | Cortical alterations in human brain organoids infected with ZIKV. a, Representative image of a human cerebral organoid showing the marginal zone (MZ), cortical plate (CP) and ventricular zone (VZ), delineated by dotted white lines. Scale bar, $200 \mu \mathrm{m}$. b. Representative images of the CP stained for CTIP2, TBR1, MAP2 or TUJ1 (neurons). Scale bar, $50 \mu \mathrm{m}$. c, Representative images of the proliferative regions in the VZ stained for Ki67, PAX6, and cleaved caspase-3 (CASP3).

Scale bar, $50 \mu \mathrm{m}$. d, Percentage of TBR1-positive cells in relation to mockinfected controls (dotted line) (MOI $=0.1 ; n=3$ replicates from three human cell lines; error bars, s.e.m.; ANOVA, $* * P=0.0025)$. e, Percentage of CTIP2-positive cells (MOI $=0.1 ; n=3$ replicates from three human

using an MOI of 0.1 and compared to mock-infected organoids at 24 and $96 \mathrm{~h}$ post-infection. We quantified the percentage of different subtypes of cortical neurons, TBR1-positive or CTIP2-positive cells (deep-layer V/VI) in the cortical plate, finding a significant reduction in their number and respective cortical plate thickness in the $\mathrm{ZIKV}^{\mathrm{BR}}$-infected organoids compared to the others. A significant reduction in TBR1-positive cells was observed in the $\mathrm{ZIKV}^{\mathrm{BR}}$-infected organoids at $96 \mathrm{~h}$ post-infection, while CTIP2-positive cells were significantly reduced in both $\mathrm{ZIKV}^{\mathrm{BR}}$ - and $\mathrm{ZIKV}^{\mathrm{AF}}$-infected organoids at the same time point (Fig. 3d, e and Extended Data Fig. 5a-f). Consistent with the reduced population of cortical neurons, we observed a significant decrease in PAX6-positive cells (dorsal forebrain progenitor cells) following ZIKV infection (Fig. 3f and Extended Data Fig. 5d). Dividing cells in the ventricular zone, detected by the population of Ki67- and SOX2-positive cells, were only significantly reduced in the $\mathrm{ZIKV}^{\mathrm{BR}}$-infected organoids (Fig. 3g, h and Extended Data Fig. 5d). As observed in our other in vitro models, the number of apoptotic cells (cleaved caspase 3- and TUNEL-positive cells) was increased in organoids infected with $\mathrm{ZIKV}{ }^{\mathrm{BR}}$, possibly explaining the decrease in the NPC population (Fig. $3 i$ and Extended Data Fig. 5g, h).

ZIKV $^{\mathrm{AF}}$ was derived from a zoonotic agent associated with primates in Africa, whereas $\mathrm{ZIKV}{ }^{\mathrm{BR}}$ is an isolate from a lineage adapted to human-to-human transmission for the past 70 years. As an entry point to establishing the potential mechanistic adaptive differences cell lines; error bars, s.e.m.; ANOVA, $* * * * P<0.001 ; * P=0.0430)$. f, Percentage of PAX6-positive cells (MOI $=0.1 ; n=3$ replicates from three human cell lines; error bars, s.e.m.; ANOVA, $* P=0.0212\left(\mathrm{ZIKV}^{\mathrm{BR}}\right)$ and $\left.* P=0.0221\left(\mathrm{ZIKV}^{\mathrm{AF}}\right)\right)$. g, Percentage of Ki67-positive cells ( $\mathrm{MOI}=0.1 ; n=3$ replicates from three human cell lines; error bars, s.e.m.; ANOVA, $* * * * P<0.001)$. h, Percentage of SOX2-positive cells (MOI $=0.1$; $n=3$ replicates from three human cell lines; error bars, s.e.m.; ANOVA, $* * * P=0.0003)$. i, Percentage of cleaved-caspase3-positive cells (CASP3) $(\mathrm{MOI}=0.1 ; n=3$ replicates from three human cell lines; error bars, s.e.m.; ANOVA, $* * * P=0.0002)$.

between $\mathrm{ZIKV}{ }^{\mathrm{BR}}$ and $\mathrm{ZIKV}{ }^{\mathrm{AF}}$ towards human cells, we also generated brain organoids from non-human primate (chimpanzee) pluripotent stem cells. We infected these chimpanzee's cerebral organoids (MOI of 0.1) and measured the impact on cortical neurons at 24 and $96 \mathrm{~h}$ post-infection. ZIKV ${ }^{\mathrm{BR}}$ failed to reduce the percentage of either TBR1or CTIP2-positive cells in non-human primates (Extended Data Fig. 5i, j). Consistently, the kinetics of infection were different between the two ZIKV isolates. While ZIKV ${ }^{\mathrm{BR}}$ did not replicate in the chimpanzee organoids, ZIKV ${ }^{\mathrm{AF}}$ seemed well adapted to these cells (Extended Data Fig. 5k).

To evaluate the causal relationship between ZIKV congenital infection and birth defects, we used a murine experimental model, in which pregnant SJL and C57BL/6 mice were infected with ZIKV ${ }^{\mathrm{BR}}$. Notably, the SJL strain was susceptible to viral infection of fetal tissues, causing severe IUGR that resembled the affected Brazilian newborns, including signs of microcephaly, such as cortical malformations ${ }^{4}$. We also showed that $\mathrm{ZIKV} \mathrm{IR}^{\mathrm{BR}}$ induced apoptosis and autophagy in the mouse neural tissue. This is in accordance with the literature, as it has been previously demonstrated that ZIKV induces and localizes in autophagic phagosomes ${ }^{14}$. To our knowledge, this is the first report showing a gene expression profile that correlates to cell death in the brains of microcephalic newborn $\mathrm{ZIKV}^{\mathrm{BR}}$-infected mice, corroborating a causal relationship. It is unclear why the virus could not cross the placenta of C57BL/6 mice, but this result may be due to the robust anti-viral 
immune response of this mouse strain, which secretes significant levels of type I/II interferon, known to confer resistance to ZIKV ${ }^{14,26}$. These data suggest that genetic differences could explain in part why some ZIKV-infected pregnant women give birth to newborns without detectable congenital brain malformations ${ }^{27}$. Nonetheless, our murine model is a valuable tool for future pre-clinical studies, such as vaccine development. The presence of major cortical histological abnormalities in the pups with IUGR prompted us to use an hPSC model to study the impact of ZIKV on neurodevelopment. ZIKV infects cells at different stages of brain maturation leading to alterations in the cortical layer organization. While this manuscript was under review, two other papers revealed the impact of previously established ZIKV strains on human organoids, confirming our observations with $\mathrm{ZIKV}^{\mathrm{BR}}$ (refs 28, 29). Finally, our data using a non-human primate organoids suggested that the $\mathrm{ZIKV}{ }^{\mathrm{BR}}$ might have experienced adaptive changes in human cells. It has been demonstrated that the Asian lineage of ZIKV is undergoing codon usage adaptation towards biases observed in highly expressed human genes ${ }^{30}$. Our findings support the hypothesis that microcephaly is a distinctive feature of recent ZIKV Asian-lineage virus, which originated in the Pacific and is now spreading in South and Central America.

Online Content Methods, along with any additional Extended Data display items and Source Data, are available in the online version of the paper; references unique to these sections appear only in the online paper.

\section{Received 19 March; accepted 4 May 2016.}

Published online 11 May 2016.

1. Dick, G. W., Kitchen, S. F. \& Haddow, A. J. Zika virus. I. Isolations and serological specificity. Trans. R. Soc. Trop. Med. Hyg. 46, 509-520 (1952).

2. Lanciotti, R. S. et al. Genetic and serologic properties of Zika virus associated with an epidemic, Yap State, Micronesia, 2007. Emerg. Infect. Dis. 14, 1232-1239 (2008)

3. Faria, N. R. et al. Zika virus in the Americas: early epidemiological and genetic findings. Science 352, 345-349 (2016).

4. de Fatima Vasco Aragao, M. et al. Clinical features and neuroimaging (CT and MRI) findings in presumed Zika virus related congenital infection and microcephaly: retrospective case series study. Br. Med. J. 353, i1901 (2016).

5. Cao-Lormeau, V. M. et al. Guillain-Barré Syndrome outbreak associated with Zika virus infection in French Polynesia: a case-control study. Lancet 387, 1531-1539 (2016).

6. Rasmussen, S. A., Jamieson, D. J., Honein, M. A. \& Petersen, L. R. Zika virus and birth defects - reviewing the evidence for causality. N. Engl. J. Med. $\mathbf{3 7 4}$, 1981-1987 (2016).

7. Campos, G. S., Bandeira, A. C. \& Sardi, S. I. Zika virus outbreak, Bahia, Brazil. Emerg. Infect. Dis. 21, 1885-1886 (2015).

8. Hayes, E. B. Zika virus outside Africa. Emerg. Infect. Dis. 15, 1347-1350 (2009).

9. Sarno, M. et al. Zika Virus infection and stillbirths: a case of hydrops fetalis, hydranencephaly and fetal demise. PLoS Negl. Trop. Dis. 10, e0004517 (2016)

10. Calvet, G. et al. Detection and sequencing of Zika virus from amniotic fluid of fetuses with microcephaly in Brazil: a case study. Lancet Infect. Dis. http:// dx.doi.org/10.1016/S1473-3099(16)00095-5 (2016).

11. Martines, R. B. et al. Notes from the field: evidence of Zika virus infection in brain and placental tissues from two congenitally infected newborns and two fetal losses - Brazil, 2015. MMWR Morb. Mortal. Wkly. Rep. 65, 159-160 (2016).

12. Mlakar, J. et al. Zika virus associated with microcephaly. N. Engl. J. Med. 374, 951-958 (2016).

13. Ventura, C. V., Maia, M., Bravo-Filho, V., Góis, A. L. \& Belfort, R., Jr. Zika virus in Brazil and macular atrophy in a child with microcephaly. Lancet 387, 228 (2016).

14. Hamel, R. et al. Biology of Zika virus infection in human skin cells. J. Virol. $\mathbf{8 9}$ 8880-8896 (2015)

15. Bell, T. M., Field, E. J. \& Narang, H. K. Zika virus infection of the central nervous system of mice. Arch. Gesamte Virusforsch. 35, 183-193 (1971).

16. Tang, H. et al. Zika virus infects human cortical neural progenitors and attenuates their growth. Cell Stem Cell 18, 587-590 (2016).

17. Faye, 0 . et al. Molecular evolution of Zika virus during its emergence in the 20(th) century. PLoS Negl. Trop. Dis. 8, e2636 (2014).
18. Brasil, P. et al. Zika virus outbreak in Rio de Janeiro, Brazil: clinical characterization, epidemiological and virological aspects. PLoS Negl. Trop. Dis. 10, e0004636 (2016).

19. Brasil, P. et al. Zika virus infection in pregnant women in Rio de Janeiro preliminary report. N. Engl. J. Med. http://dx.doi.org/10.1056/ NEJMoa1602412 (2016)

20. Jang, E. A., Longo, L. D. \& Goyal, R. Antenatal maternal hypoxia: criterion for fetal growth restriction in rodents. Front. Physiol. 6, 176 (2015).

21. Lizarraga, S. B. et al. Cdk5rap2 regulates centrosome function and chromosome segregation in neuronal progenitors. Development 137, 1907-1917 (2010).

22. Pulvers, J. N. et al. Mutations in mouse Aspm (abnormal spindle-like microcephaly associated) cause not only microcephaly but also major defects in the germline. Proc. Natl Acad. Sci. USA 107, 16595-16600 (2010).

23. de Paula Freitas, B. et al. Ocular findings in infants with microcephaly associated with presumed Zika virus congenital infection in Salvador, Brazil. JAMA Ophthalmol. 134, 529-535 (2016).

24. Nowakowski, T. J. et al. Expression analysis highlights $A X L$ as a candidate Zika virus entry receptor in neural stem cells. Cell Stem Cell 18, 591-596 (2016).

25. Lancaster, M. A. et al. Cerebral organoids model human brain development and microcephaly. Nature 501, 373-379 (2013).

26. Rossi, S. L. et al. Characterization of a novel murine model to study Zika virus. Am. J. Trop. Med. Hyg. http://dx.doi.org/10.4269/ajtmh.16-0111 (2016).

27. Cauchemez, S. et al. Association between Zika virus and microcephaly in French Polynesia, 2013-15: a retrospective study. Lancet 387, 2125-2132 (2016).

28. Garcez, P. P. et al. Zika virus impairs growth in human neurospheres and brain organoids. Science 352, 816-818 (2016)

29. Qian, X. et al. Brain-region-specific organoids using mini-bioreactors for modeling ZIKV exposure. Cell 165, 1-17 (2016).

30. Freire, C. C. d. M. et al. Spread of the pandemic Zika virus lineage is associated with NS1 codon usage adaptation in humans. Preprint at http://biorxiv.org/ content/early/2015/11/25/032839 (2015)

Acknowledgements This work was supported by grants from the Zika Network FAPESP projects 2011/18703-2 and 2014/17766-9, the NGO 'The Tooth Fairy Project', the National Institutes of Health through the U19MH107367, R01MH094753 and an NARSAD Independent Investigator Grant to A.R.M. We would like to thank M. Gonçalves and M. A. Miglino for scientific discussions, G. Amarante-Mendes for the FITC-Annexin V reagent, M. Zatz for the SJL mice, E. Durigon and his group for the ZIKVBR aliquots, P. Vasconcelos for providing a lyophilized ZIKVBR seed, N. Olsen for reagent and equipment support, D. Candido for analysis support, F. Mastrantonio for drawings and R. E. Grassi for electron and confocal microscopy support.

Author Contributions F.R.G. derived the NPCs, neurons and neurospheres, performed the viral infections and cell analyses and analysed the data. I.R.F. performed the viral infections of cells, processed and analysed infected brain organoids, prepared manuscript figures and analysed the data. F.B.R. derived the NPCs, performed immunostainings and analyses, prepared manuscript figures and analysed the data. B.C.F. revised the manuscript and with S.R. generated the organoid cultures from iPSCs and assisted with the immunofluorescence staining and experimental design. J.L.M.D. performed macroscopic and microscopic staining and analyses of the mice. K.O.P.G. performed the TEM experiments, RNA extraction and quantification and histopathological analyses. C.B. and N.S. performed RNA extraction and quantification and prepared figures. G.C.P. performed cell cultures, analysed the data and revised the manuscript. C.M.P., I.C., C.L.F., W.N.B. and C.R. performed cell death qPCR assays and flow cytometry, D.G.A performed flow cytometry staining protocols and analysed the data. C.M.P., I.C. and D.G.A. infected and observed the pregnant mice daily. C.M.P., C.L.F., I.C. and C.R. processed the mouse tissues for virus quantification and further analyses. D.P.F., A.T.G. and C.A.B. performed the CT scans and analysed and plotted the data. C.T.B. and E.A.M. performed virus amplification, titration and gene expression analysis. A.A.S. provided MR766 and YFV-17D isolates and serological reagents. P.M.A.Z. designed the experiments and revised the manuscript. J.P.S.P., A.R.M. and P.C.B.B.-B. designed the experiments, analysed the data and wrote the manuscript.

Author Information Reprints and permissions information is available at www.nature.com/reprints. The authors declare no competing financial interests. Readers are welcome to comment on the online version of the paper. Correspondence and requests for materials should be addressed to P.C.B.B.-B. (patriciacbbbraga@usp.br); A.R.M. (muotri@ucsd.edu) or J.P.S.P. (jeanpierre@usp.br). 


\section{METHODS}

No statistical methods were used to predetermine sample size. The experiments were not randomized and the investigators were not blinded to allocation during experiments and outcome assessment

Viral culture and amplification. A lyophilized ZIKV isolate from a clinical case in Brazil $\left(\mathrm{ZIKV}^{\mathrm{BR}}\right)$, provided by the Evandro Chagas Institute in Belém, Pará, was reconstituted in $0.5 \mathrm{ml}$ of sterile DEPC water. The African-lineage MR-766 $\left(\mathrm{ZIKV}^{\mathrm{AF}}\right)$, a reference strain isolated in Uganda in 1947 and the Yellow Fever vaccine strain $(\mathrm{YFV}-17 \mathrm{D})^{31}$, both used here as controls, were provided by the Institute Pasteur in Dakar, Senegal. Aedes albopictus mosquito cells (C6/36 cells) were previously prepared to culture the three viruses. C6/36 cell culture was maintained using Leibovitz's L-15 medium supplemented with $10 \%$ fetal bovine serum (FBS) (Gibco), 1\% non-essential amino acids (Gibco), $1 \%$ sodium pyruvate (Gibco), $1 \%$ penicillin/streptomycin (Gibco), $0.05 \%$ of amphotericin B (Gibco) and kept at $27^{\circ} \mathrm{C}$ in the absence of $\mathrm{CO}_{2}$. After reaching an approximately $70 \%$ confluent monolayer, $50 \mu \mathrm{l}$ of each viral sample was inoculated into $\mathrm{C} 6 / 36$ with an hour of adsorption, with gentle shaking every $10 \mathrm{~min}$ to allow the homogeneous adsorption of the viruses. At the end of the adsorption period, $5 \mathrm{ml}$ of the culture media was added, plus $2 \%$ FBS, $1 \%$ non-essential amino acids and $1 \%$ sodium pyruvate. The cultures were then incubated under the same adsorption conditions. In the first subculture (T1), the infected cells were less confluent compared to the control cells but had few noticeable morphological changes. On the fourth day after infection, the second subculture (T2) was made blindly by transferring $500 \mu \mathrm{l}$ of the T1 supernatant, followed by the third subculture, which was collected on the eighth day after infection (T3). Pronounced cytopathic effects were perceived beginning at $\mathrm{T} 2$. The supernatants were harvested, titrated and $\mathrm{T} 3$ was used for the experimental inoculation.

Virus titration. Titration (in PFU ml ${ }^{-1}$ ) of each C6/36 subculture was obtained by plaque assay to determine the amount of infectious viral particles (PFU). The virus titration was performed in porcine kidney epithelial (PS) cells and in L15 medium with 5\% FBS. Briefly, the virus titration was done using $200 \mu \mathrm{l}$ of L15 medium ( $5 \% \mathrm{FBS}, 1 \%$ penicillin/streptomycin, and $1 \%$ glutamine) in a 24 -well plate. Then a serial dilution of each virus stock from $\mathrm{ZIKV}{ }^{\mathrm{BR}}$, ZIKV ${ }^{\mathrm{AF}}$ and YFV-17D in L15 medium was performed, from $10^{-1}$ to $10^{-11}$.Then, $200 \mu \mathrm{l}$ of each dilution was added in each 24 -well plate. After this, $1 \times 10^{6} \mathrm{PS}$ cells were seeded in each well of a 24-well plate for at least $3 \mathrm{~h}$ at $37^{\circ} \mathrm{C}$ to allow virus adsorption and PS cell adherence. Later, each well was overlaid with complete carboxymethyl cellulose (CMC) medium ( $0.6 \%$ in L15 supplemented with $3 \%$ FBS). After 5 days of incubation at $37^{\circ} \mathrm{C}$, the plaque visualization was made using blue-black staining solution. The most appropriate viral dilution was estimated to determine the amount of infected cells visible $\left(\mathrm{PFU} \mathrm{ml}{ }^{-1}\right)$. For $\mathrm{ZIKV}^{\mathrm{BR}}$, the first $\mathrm{C} 6 / 36$ subculture had a titre of $6 \times 10^{8}$. The following subcultures had titres of $7.5 \times 10^{6}(\mathrm{~T} 2)$ and $4 \times 10^{12}(\mathrm{~T} 3)$. All the subculture aliquots were stored in cryovials and maintained in liquid nitrogen or were distributed to the ZIKV São Paulo task force.

In vivo infection. Pregnant mice, $6-8$ weeks of age, C57BL/6 or SJL (JAX), were infected intravenously with $200 \mu \mathrm{l}$ of $\mathrm{ZIKV}^{\mathrm{BR}}$-infected $\mathrm{C} 6 / 36$ cell supernatant containing $1 \times 10^{3}, 4 \times 10^{10}$ or $1 \times 10^{12} \mathrm{PFU} \mathrm{m}^{-1}$ of virus on day $10-13$ of gestation. The animals were observed daily. All the experiments were performed with the approval of the Institute of Biomedical Sciences Ethics Committee protocol number 05/2016.

Real-time PCR. RNA was extracted from each sample (cells, supernatant of cell culture or mouse tissue) using the QIAamp UltraSens Virus Kit (Qiagen) or TRIzol reagent (Invitrogen). All RNA pellets were resuspended in $30 \mu \mathrm{l}$ of RNase-free distilled water, quantified using a NanoDrop spectrophotometer (NanoDrop Technologies) and stored at $-80^{\circ} \mathrm{C}$. The set of primers/probes specific for ZIKV were synthesized by Sigma Life Science, with 5- FAM as the reporter dye for the probe. The set of primers/probes ZIKV 835, ZIKV 911c and ZIKV 860-FAM were previously described ${ }^{2}$. The real-time reaction was performed with $10 \mu 1$ of each sample and $10 \mu \mathrm{l}$ of the AgPath-IDTM One-Step RT-PCR reagents (Applied Biosystems). The amplification was done in an Applied Biosystems 7500 real-time PCR system, and involved activation at $45^{\circ} \mathrm{C}$ for $15 \mathrm{~min}, 95^{\circ} \mathrm{C}$ for $15 \mathrm{~min}$ followed by 40 amplification cycles of $95^{\circ} \mathrm{C}$ for $15 \mathrm{~s}, 60^{\circ} \mathrm{C}$ for $15 \mathrm{~s}$, and $72^{\circ} \mathrm{C}$ for $30 \mathrm{~s}$. The real-time data were analysed using SDS software from Applied Biosystems. For the detection and quantification of viral RNA, the real-time PCR of each sample was compared with threshold cycle $\left(C_{\mathrm{t}}\right)$ value with a ZIKV plasmid standard curve, which was obtained carrying out serial dilutions of a clone of the envelope gene of an isolate from the 2007 Yap Island outbreak (provided by the Institute Pasteur in Dakar, Senegal). For the detection and quantification of YFV RNA, a YFV-specific real-time assay was applied. The fold changes of gene expression were calculated in comparison to the values for the YFV controls ${ }^{31}$. The positive PCR control $C_{\mathrm{t}}$ value was used to normalize gene expression and determine fold changes during the 96 hours post-infection. The RPLA27 gene (60S ribosomal protein L27) was used as endogenous control for the PCR reactions ${ }^{30}$. For the TAM receptors detection,
NPCs or neurons from two donors were or were not infected with $\mathrm{ZIKV} \mathrm{VR}^{\mathrm{BR}}$, at $10 \mathrm{MOI}$ for $48 \mathrm{~h}$ and were submitted to standard TRIzol (Invitrogen) protocol for RNA extraction. Total RNA was quantified using a NanoDrop spectrophotometer and $2 \mu \mathrm{g}$ was used for further cDNA synthesis using the superscript III reversetranscription polimerase (Invitrogen) according to manufacturer's protocol. qPCR was performed using Taqman probes (Extended Data Table 1) and the QuantStudio 12K Flex Real-Time PCR System (Applied Biosystems). For normalization ACTB was used as a housekeeping gene.

Cell death pathway analysis. One microgram of total RNA from brains of 4 pups, 2 pooled mock and 2 pooled $\mathrm{ZIKV}^{\mathrm{BR}}$-infected from SJL mothers were submitted to gene expression analysis for cell death target genes using the RT2 Profiler PCR Array Mouse Cell Death PathwayFinder (cat. no. PAMM-212ZA- Qiagen) according to the manufacturer's protocols. qPCR was performed in the QuantStudio $12 \mathrm{~K}$ Flex Real-Time PCR System (Applied Biosystems). To evaluate gene expression, we established a fold change threshold of at least twofold up- or downregulation compared to mock infected samples. Statistical analysis was performed using the RT2 profiler RT-PCR array data analysis software v3.5.

NPCs, neurons, neurospheres and organoids. We used three human and two chimpanzee iPSC clones that were previously characterized in the Beltrão-Braga and Muotri laboratories ${ }^{32-35}$ plus H9 human embryonic stem cells (hESC) for all the experiments using pluripotent stem cells. All the cell lines tested negative for mycoplasma contamination. Briefly, high passages of iPSC/hESC colonies on feeder-free plates were maintained for 5 days with mTSeR media (Stem Cell Technologies). On the fifth day, the medium was changed to N2 media (DMEM/ F12 medium supplemented with 1X N2 supplement (Invitrogen) and the dual SMAD inhibitors, $1 \mu \mathrm{M}$ dorsomorphin (Tocris) and $1 \mu \mathrm{M}$ SB431542 (Stemgent), for $48 \mathrm{~h}$. Further, the colonies were detached from the plate and cultured in suspension as embryoid bodies (EBs) for 5 days at 90 r.p.m. in N2 media with the dual SMAD inhibitors. The EBs were plated on matrigel-coated plates with NBF media composed of the following: DMEM/F12 media supplemented with $0.5 \mathrm{X} \mathrm{N} 2$, $0.5 \mathrm{X}$ B27 supplement (Gibco), $20 \mathrm{ng} \mathrm{ml}^{-1}$ of FGF2 and 1\% penicillin/streptomycin. The emerged rosettes containing the NPCs were manually picked, dissociated and plated in a double-coated plate with poly-ornithine $\left(10 \mu \mathrm{g} \mathrm{ml}^{-1}\right.$, Sigma-Aldrich) and laminin $\left(2.5 \mu \mathrm{g} \mathrm{ml}^{-1}\right.$, Gibco). The NPC population was expanded using NBF media. The neuronal differentiation induction protocol consisted of treating the confluent NPC plate with $10 \mu \mathrm{M}$ ROCK inhibitor for $48 \mathrm{~h}$ (Y-27632, Calbiochem) in the absence of FGF in the media, with regular media changes every 3 or 4 days. Neurons were considered completely differentiated and ready to experiments after 28 days. To produce neurospheres, NPC were scrapped from the plates and submitted to continuous shaking for 5-7 days at 90 r.p.m. in NBF media. Cerebral organoids were generated as previously described ${ }^{25,36}$. All experiments were performed with the approval of the Institute of Biomedical Sciences Ethics Committee protocol number 1001

In vitro infection. NPCs, neurons, neurospheres and organoids were infected with $\mathrm{ZIKV}^{\mathrm{BR}}, \mathrm{ZIKV}^{\mathrm{AF}}$, YFV and mock (culture supernatant from uninfected C6/36 cells). NPCs were seeded in plates in 24 -well plates and after $24 \mathrm{~h}$ viral samples were diluted to the desired MOI $(0.1 ; 1$ or 10$)$ and added to the cells. For viral adsorption, cells in monolayer were incubated for $1 \mathrm{~h}$ at $4^{\circ} \mathrm{C}$ with gentle agitation every $10 \mathrm{~min}$. Next, the inoculum was removed and cells were washed once with PBS (USB Corporation). Culture medium was added to each well, and cells were incubated at $37^{\circ} \mathrm{C}$ and $5 \% \mathrm{CO}_{2}$ for the duration of the experiment. For neurospheres, NPCs were kept in constant shaking. For neuronal infection, NPCs were previously differentiated for 28 days and then neurons were infected with the desired MOI. For organoids, the number of cells available for infection was estimated to be $2.5 \times 10^{4}$ cells, as calculated by dividing the average surface area of a typical organoid by the average area of a typical cell (that is, a fibroblast). This calculus was used to estipulate the desired 0.1 MOI. For mock controls, the same volume of supernatant was added to each experiment, and the same procedures were followed.

Immunofluorescence. Cells were fixed using paraformaldehyde, $4 \%$ in PBS, for $15 \mathrm{~min}$ at room temperature. After washing, the cells were permeabilized with $0.1 \%$ Triton X-100 (Promega) diluted in PBS for 15 min. After blocking with $2 \%$ of BSA (Sigma-Aldrich) for $4 \mathrm{~h}$, primary antibodies directed against the following were added: anti-ZIKV (polyclonal mouse, Institute Pasteur in Dakar, 1:80), anti-Flavivirus D1-4G2-4-15 (polyclonal mouse, Millipore, 1:100), 1:50, anti-MAP2 (chicken, Abcam ab5392, 1:200), anti-cleaved-caspase-3 (rabbit, Cell Signaling \#9661, 1:400), anti-Sox2 (mouse, Abcam ab97959), anti-GFAP (rabbit, Abcam, 1:500) and anti-Mushashil (rabbit, Abcam, 1:1000) (Extended Data Table 2). The cells were incubated overnight at $4{ }^{\circ} \mathrm{C}$. Secondary antibodies were added for a one-hour incubation at room temperature: anti-mouse Alexa Fluor 488, anti-chicken Alexa Fluor 647, anti-rat Alexa Fluor 555 and anti-rabbit Alexa Fluor 555 (Invitrogen). The nuclei were stained with DAPI (Invitrogen, 1:10,000) diluted in a PBS $1 \times$ solution for $5 \mathrm{~min}$ and mounted with DPX (Sigma). Images were acquired with Nikon Eclipse 80i. Analysis of data was performed using software NIS Elements 3.22 (Tokyo, Japan). 
Cerebral organoids analyses. Human and chimp organoids were infected with an MOI of 0.1 and analysed after 24 and $96 \mathrm{~h}$ post-infection. Organoids were cryosectioned at $20 \mu \mathrm{m}$. Immunofluorescence was performed after blocking sections in a solution with $0.1 \%$ Triton and 3\% BSA (Gemini) for $1 \mathrm{~h}$ at room temperature. The primary antibodies were diluted in a solution with $0.1 \%$ Triton and $3 \%$ BSA, and the sections were incubated with following antibodies: anti-ZIKV, anti-Flavivirus, anti-MAP2, anti-cleaved-caspase-3 and anti-Sox2, all mentioned above, and antiPAX6 (rabbit, Covance PRB-278P, 1:100), anti-TBR1 (rabbit, Abcam ab31940, 1:300), CTIP2 (rat, Abcam ab18465, 1:100) and Ki67 (rabbit, Abcam ab15580, 1:100). The sections were blocked with $0.1 \%$ Triton (Sigma-Aldrich) and 3\% BSA for $30 \mathrm{~min}$ at room temperature and the secondary antibodies previously diluted, the same mentioned above, were added. The nuclei were stained with DAPI, as mentioned above and slides were mounted with DPX (Sigma-Aldrich).

Transmission electron microscopy. Cell pellet was fixed using a 3\% glutaraldehyde solution (Merck) at $4{ }^{\circ} \mathrm{C}$ for $2 \mathrm{~h}$, rinsed in three changes of $\mathrm{PBS}$ for $1 \mathrm{~h}$, and incubated for $16 \mathrm{~h}$ at $4{ }^{\circ} \mathrm{C}$. The next day, post-fixation was performed with $1 \%$ of osmium tetroxide for $30 \mathrm{~min}$ at room temperature. Dehydration was carried out gradually with a series of ethanol concentrations: $70 \%, 95 \%$ and $100 \%$. Sample was taken through two changes of propylene oxide and placed at a 1:1 ratio with embedding medium for $1 \mathrm{~h}$ in a rotary mixer followed by $100 \%$ embedding medium at room temperature for $24 \mathrm{~h}$. Fresh embedding medium was placed overnight at $37^{\circ} \mathrm{C}$ and polymerized in oven to $24 \mathrm{~h}$. Ultrathin sections were cut and stained with uranyl acetate and lead citrate. The cells were visualized with a transmission electron microscope (JEOL, JEM 1011, Peabody, Massachusetts, USA). All experimental analyses were performed blinded to the treatment.

Flow cytometry. Cells were infected with an MOI of 10 or 1, prepared using supernatants from infected C6/36, and equal volume of mock. Cellular infection occurred at $4^{\circ} \mathrm{C}$ for $1 \mathrm{~h}$ with cell homogenization every $10 \mathrm{~min}$. After that, the cells were washed once and then maintained at $37^{\circ} \mathrm{C}$ in $\mathrm{CO}_{2}$ incubators with medium, as described before. After $24,48,72$ and $96 \mathrm{~h}$ post-infection the cells were harvested and then submitted to a staining protocol for annexin $\mathrm{V}$ and propidium iodide (PI) (BD Biosciences). The cells were washed twice with PBS and were harvested with $200 \mu \mathrm{l}$ of trypsin $0.25 \%$ (LGC) for $10 \mathrm{~min}$ at $37^{\circ} \mathrm{C}$. Next, the cell suspensions were washed in DMEM with $10 \%$ of FBS and centrifuged for 5 min at $450 g$ and $4^{\circ} \mathrm{C}$. The cells were then resuspended in $20 \mu \mathrm{l}$ of annexin $\mathrm{V}$ binding buffer in 96-well round-bottom plates and with $1 \mu \mathrm{l}$ of FITC-annexin V $+1 \mu \mathrm{l}$ of PI and then incubated at room temperature for $15 \mathrm{~min}$ protected from light. After incubation period, the samples were added to $80 \mu \mathrm{l}$ of binding buffer and acquired in the $\mathrm{BD}$ FACS Accuri C6 (BD Biosciences) flow cytometer.

Computed tomography. Mice were properly anaesthetized with isoflurane and immobilized on their right side on the bed with a piece of gauze and positioned with the whole body in the field of view (FOV). CT images were acquired using small animal imaging equipment (Triumph Trimodality Gamma Medica Ideas) with $45 \mathrm{kVp}, 0.4 \mathrm{~mA}$ and $2.13 \mathrm{~min}$ of X-ray exposition (512 projections over $360^{\circ}$ ).
The images were reconstructed using the FBP (filtered back projection) algorithm, a matrix of $512 \times 512$, smoothing filter and a pixel size of $92-117 \mu \mathrm{m}$ (according to the animal size). Experienced evaluators, who were blinded to the animal group assignments, performed images analyses using the AMIDE 1.0.4, General Public License software. Fiducial marks were added to measure the distance between points considering, visually, the larger axis of the brain in the sagittal plane for posterior-anterior and superior-inferior distances and the coronal plane for the lateral right-left. For measuring whole-body length, the distance between the superior point of the brain to the first vertebra of the tail was used. The thorax measure was made from the third rib (right-left) in the coronal plane to the spinal cord level. The results are presented in $\mathrm{mm}$.

Histologic processing. Tissue histology was performed using a dehydrating protocol with two alcohol baths of $95 \%$ (the first for $1 \mathrm{~h}$ and $15 \mathrm{~min}$ and the second for $30 \mathrm{~min}$ ), three absolute alcohol baths ( $1 \mathrm{~h}$ for the first followed by $3 \mathrm{~h}$ for the second and $2 \mathrm{~h}$ for the third), followed by clarification with three baths of xylene (the first for $30 \mathrm{~min}$ and the next two for $1 \mathrm{~h}$ each). Finally, the material was added to three paraffin baths (the first for $30 \mathrm{~min}$ and the second two for $1 \mathrm{~h}$ each). Then the material was immersed in paraffin and cut with a microtome to a thickness of $5 \mathrm{~mm}$. The deparaffinization protocol consisted of three xylol baths heated in an oven for $30 \mathrm{~min}$ each, two baths of absolute alcohol for $2 \mathrm{~min}$ each, two baths of $95 \%$ alcohol lasting $2 \mathrm{~min}$ each, an alcohol in water bath (85\%) for $2 \mathrm{~min}$ and the las bath in $70 \%$ alcohol for $2 \mathrm{~min}$. The haematoxylin and eosin staining protocol began with two quick baths in running water, followed by a 2 -min bath in distilled water, a 2-min bath in haematoxylin, a 5-min bath in running water, a 1-min bath in eosin, followed by 1 -min in a fast-flowing water bath, two baths of $95 \%$ ethanol for 2 min each, two baths of absolute ethanol for 2 min each, ending with three baths in xylene for 2 min each. Slides were mounted using Permount (Sigma-Aldrich) and analysed on multiple coronal slices in glass slides using light microscopy (Olympus BX40, ZEISS KS400) on a genotype-blinded fashion.

31. Stock, N. K. et al. Biological and phylogenetic characteristics of yellow fever virus lineages from West Africa. J. Virol. 87, 2895-2907 (2013).

32. de Jonge, H. J. et al. Evidence based selection of housekeeping genes. PLoS One 2, e898 (2007)

33. Marchetto, M. C. et al. A model for neural development and treatment of Rett syndrome using human induced pluripotent stem cells. Cell 143, 527-539 (2010).

34. Marchetto, M. C. et al. Differential L1 regulation in pluripotent stem cells of humans and apes. Nature 503, 525-529 (2013).

35. Beltrao-Braga, P. I. et al. Feeder-free derivation of induced pluripotent stem cells from human immature dental pulp stem cells. Cell Transplant. http://dx. doi.org/10.3727/096368911X566235 (2011).

36. Lancaster, M. A. \& Knoblich, J. A. Organogenesis in a dish: modeling development and disease using organoid technologies. Science 345, 1247125 (2014). 
a

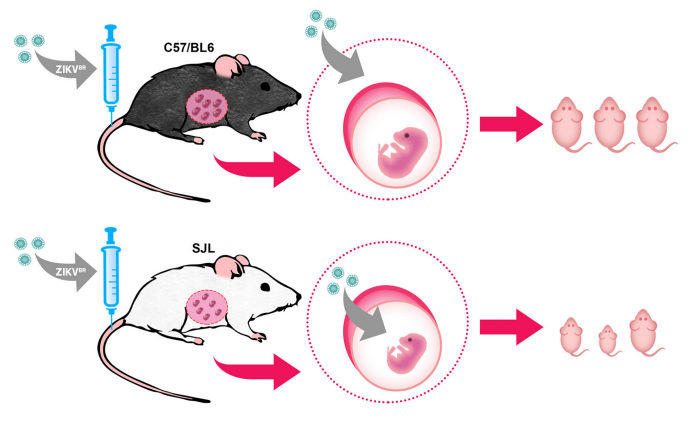

d
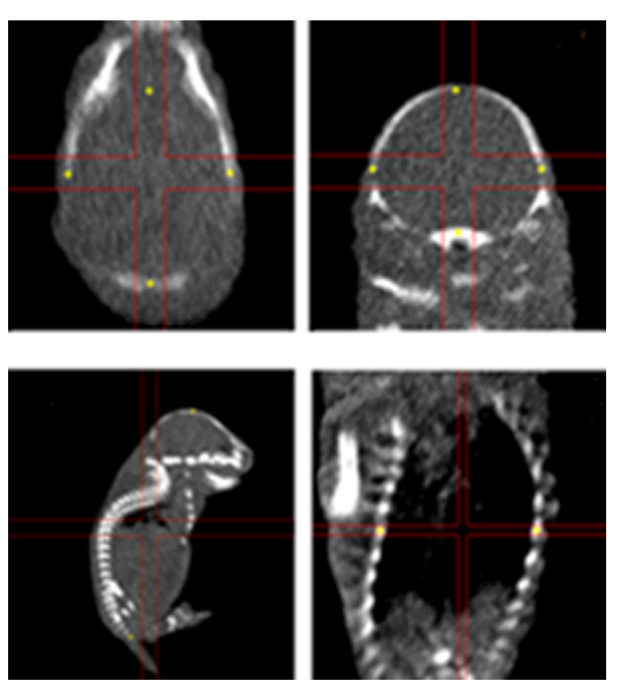

f

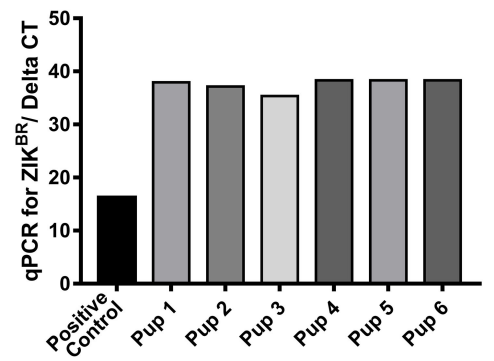

$\mathrm{h}$
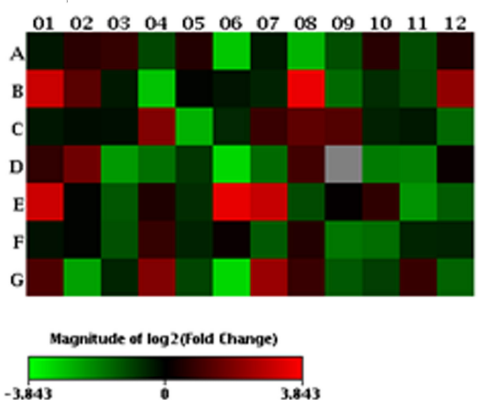

Extended Data Figure 1 | Impact of ZIKV ${ }^{\mathrm{BR}}$ infection in the C57BL/6 and SJL mice. a, Scheme for infecting mice and the follow-up analyses. Pregnant females at approximately day $10-13$ of gestation were challenged with $4 \times 10^{10} \mathrm{PFU}$ of $\mathrm{ZIKV}{ }^{\mathrm{BR}}$ via an intravenous route. Their pups were analysed immediately after birth for signs of malformation. b, A representative pup from mock-infected and the $\mathrm{ZIKV}^{\mathrm{BR}}$-infected C57BL/6 mice. Scale bar, $1 \mathrm{~cm}$. c, C57BL/6 pups born with no gross morphological changes or size differences compared to mock controls ( $n=21$ pups from three separate litters, error bars, s.e.m, $t$-test). b

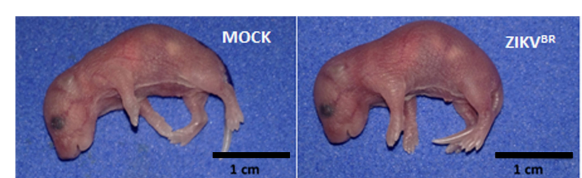

C
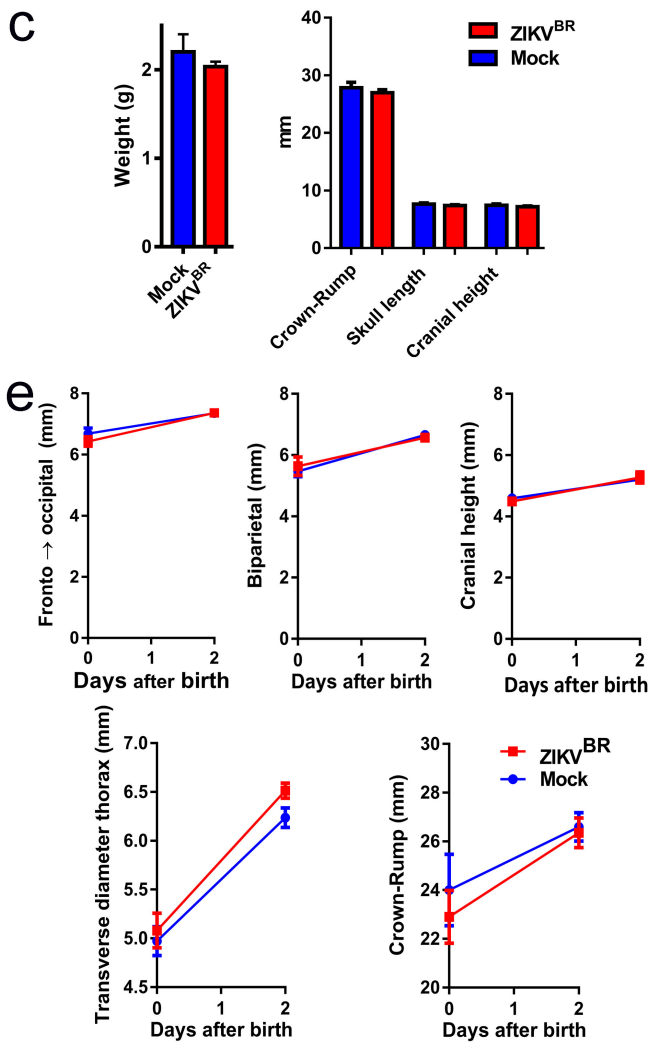

9

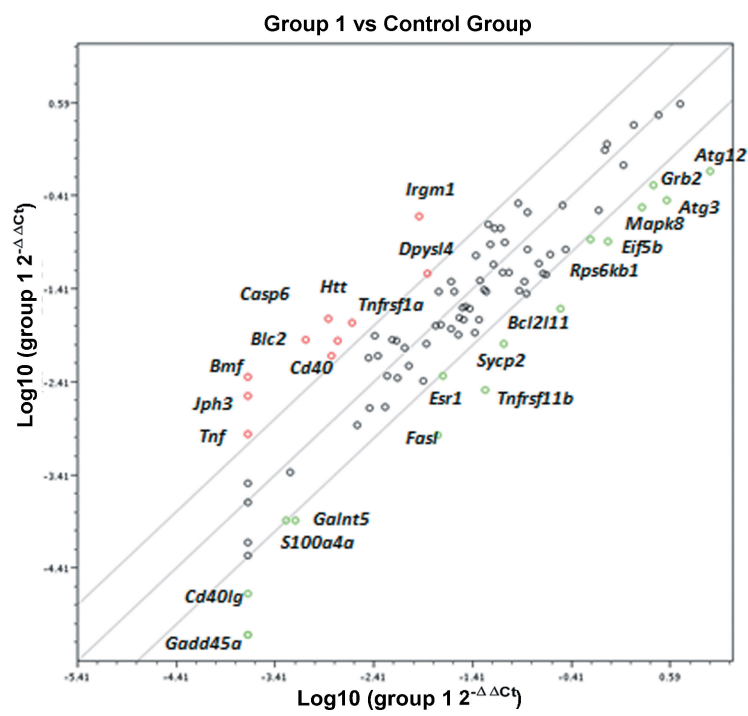

d, e, CT analysis confirmed lack of anatomical alterations ( $n=21$ pups from three separate litters, error bars, s.e.m, $t$-test). For scale, the crosses indicate $1.2 \mathrm{~mm}$ (top left; top right; bottom left) and $0.6 \mathrm{~mm}$ (bottom right). f, $\mathrm{ZIKV}^{\mathrm{BR}} \mathrm{RNA}$ was not detected in the brains of six C57BL/6 pups. $g$, Cell death pathway signature revealed by qPCR gene expression in the brains of the ZIKV ${ }^{\mathrm{BR}}$-infected SJL pups ( $n=2$ technical replicates of pooled RNA from two pups each group; threshold = twofold). $\mathbf{h}$, Heat map representation of misregulated genes in $\mathbf{g}$. 


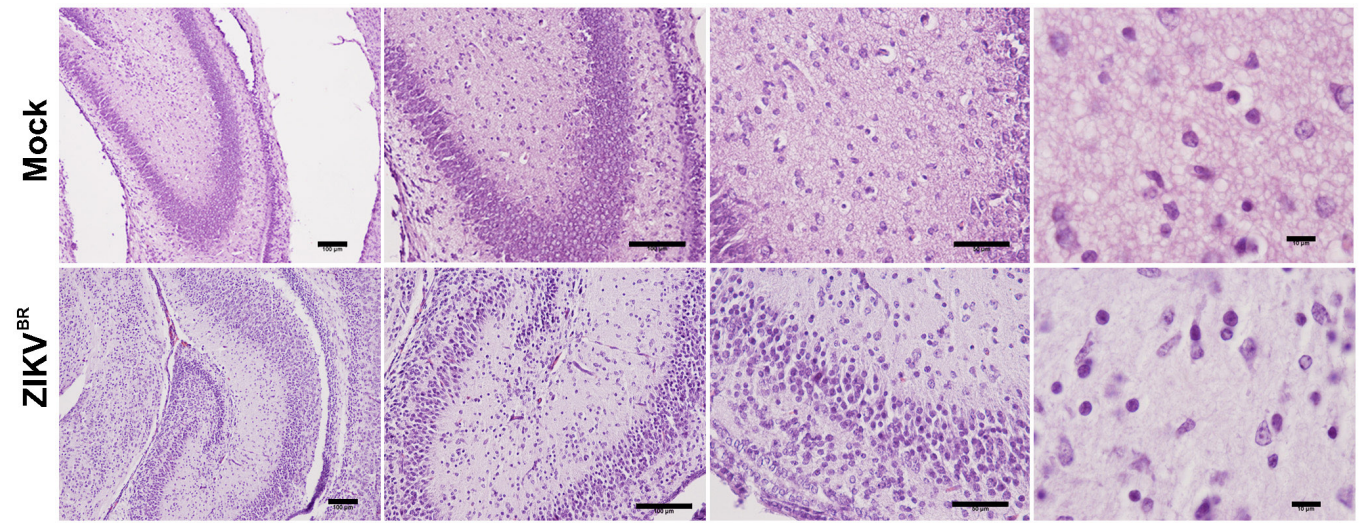

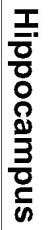
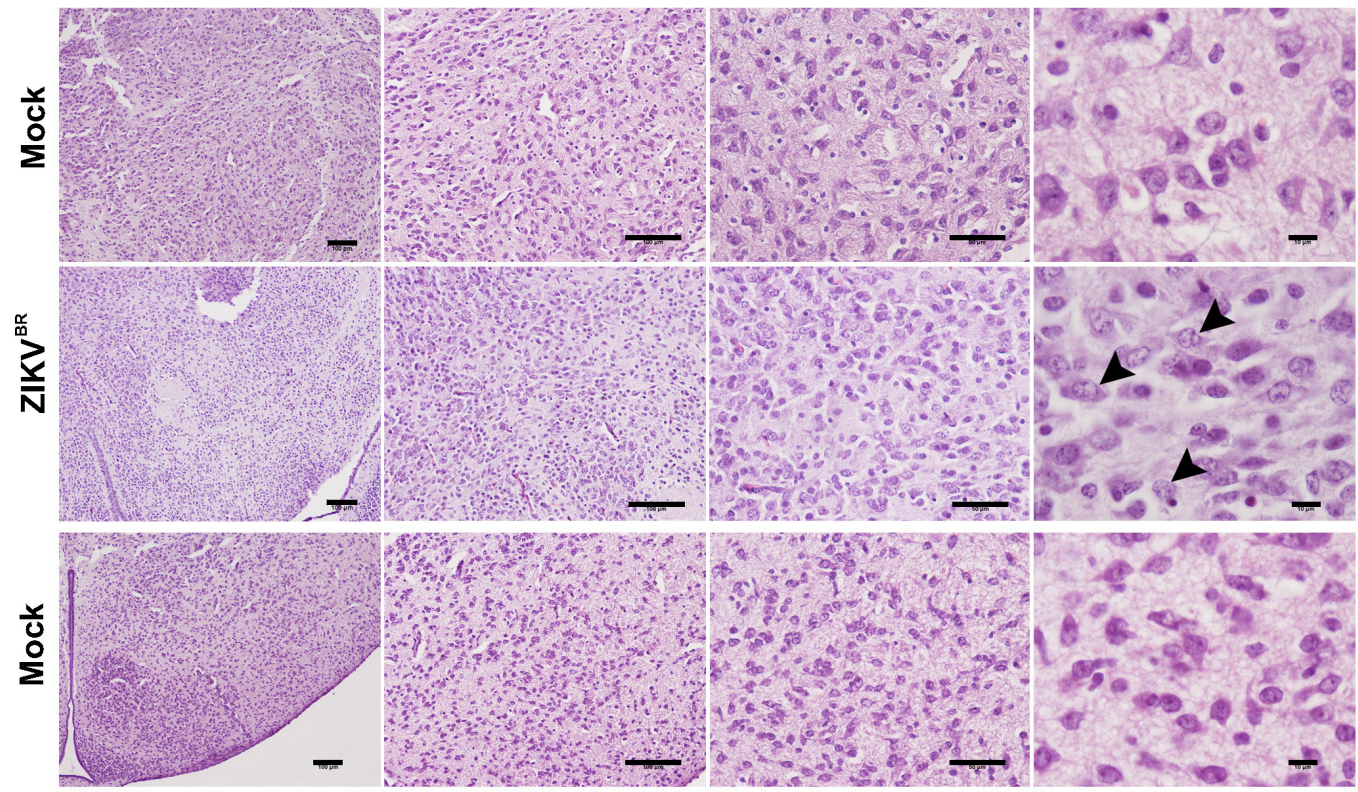

$\frac{\text { 궁 }}{\frac{9}{9}}$
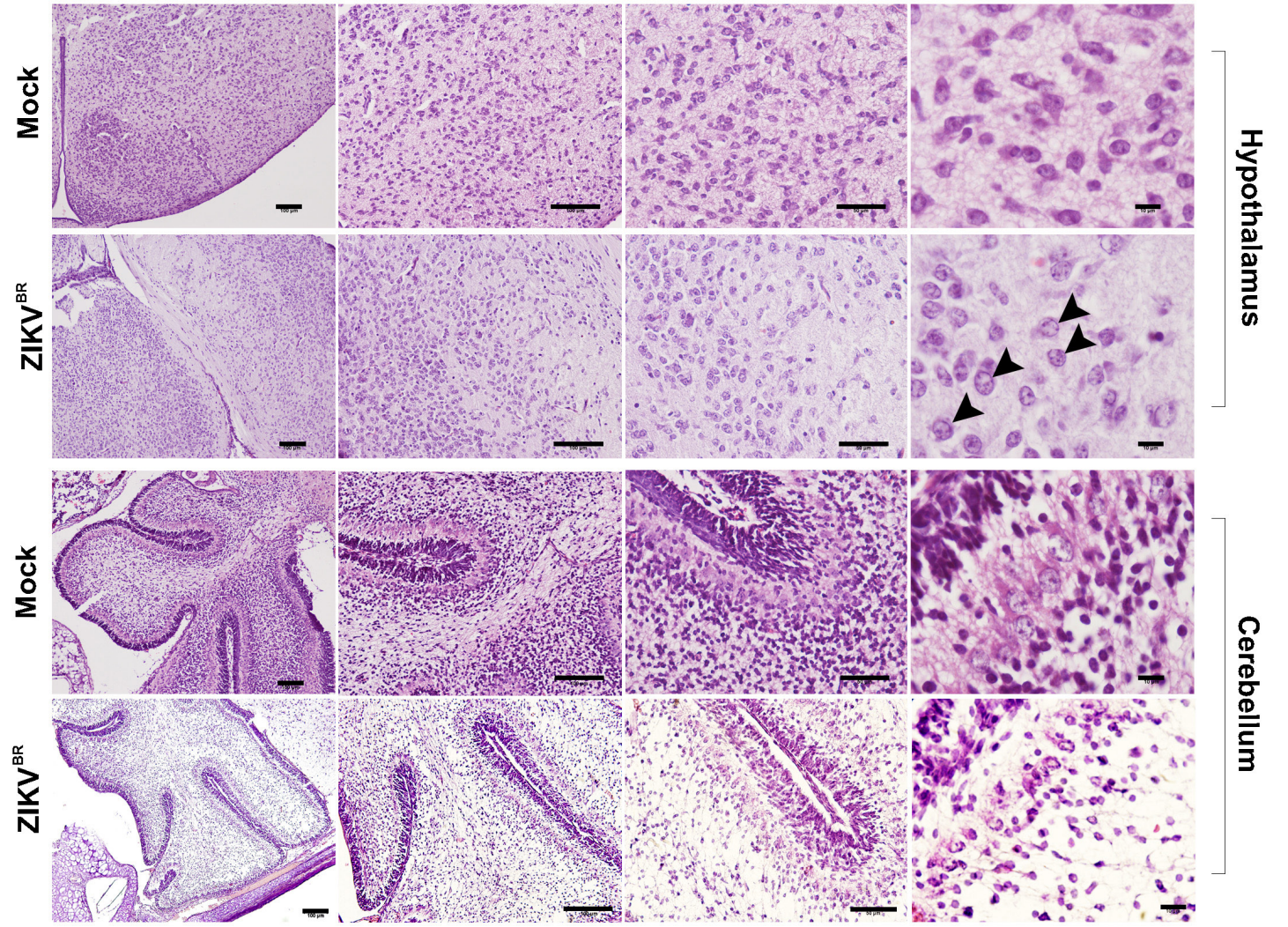

Extended Data Figure $2 \mid$ Histopathological analysis of brains from $\mathrm{ZIKV}^{\mathrm{BR}}$-infected SJL pups. Morphological aspect of hippocampus, thalamus, hypothalamus and cerebellum from brains of pups born from mothers infected with $\mathrm{ZIKV}{ }^{\mathrm{BR}}$. Arrowheads indicate intranuclear vacuoles and 'empty' nuclei aspect with chromatin margination observed in thalamus and hypothalamus. Scale bar from left to right: $100 \mu \mathrm{m}, 100 \mu \mathrm{m}$, $50 \mu \mathrm{m}$ and $10 \mu \mathrm{m}$. 
a

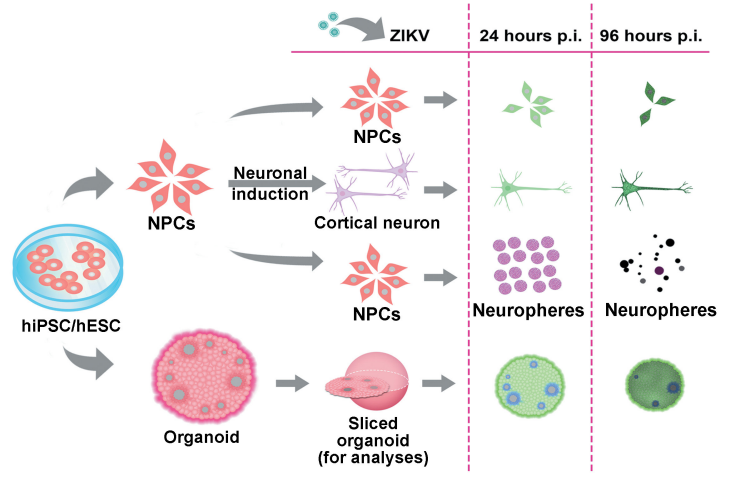

C

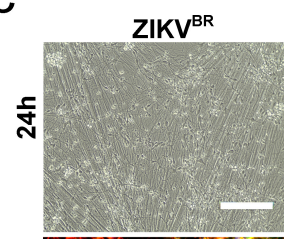

Neurons
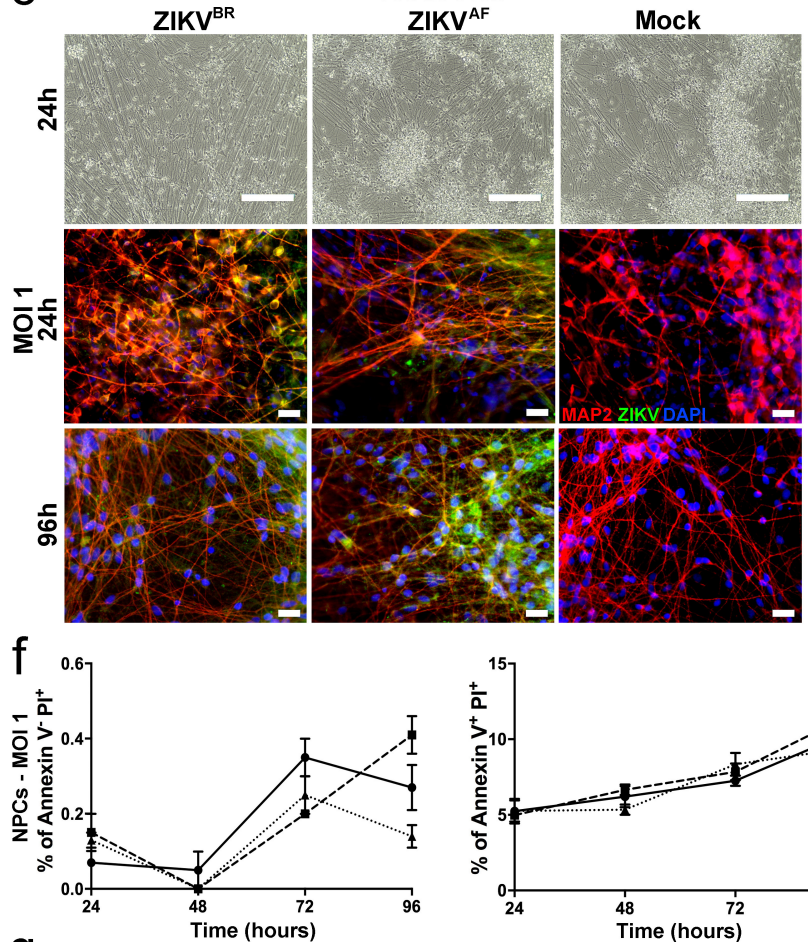

9

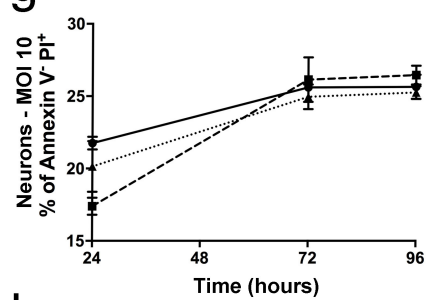

$\mathrm{h}$
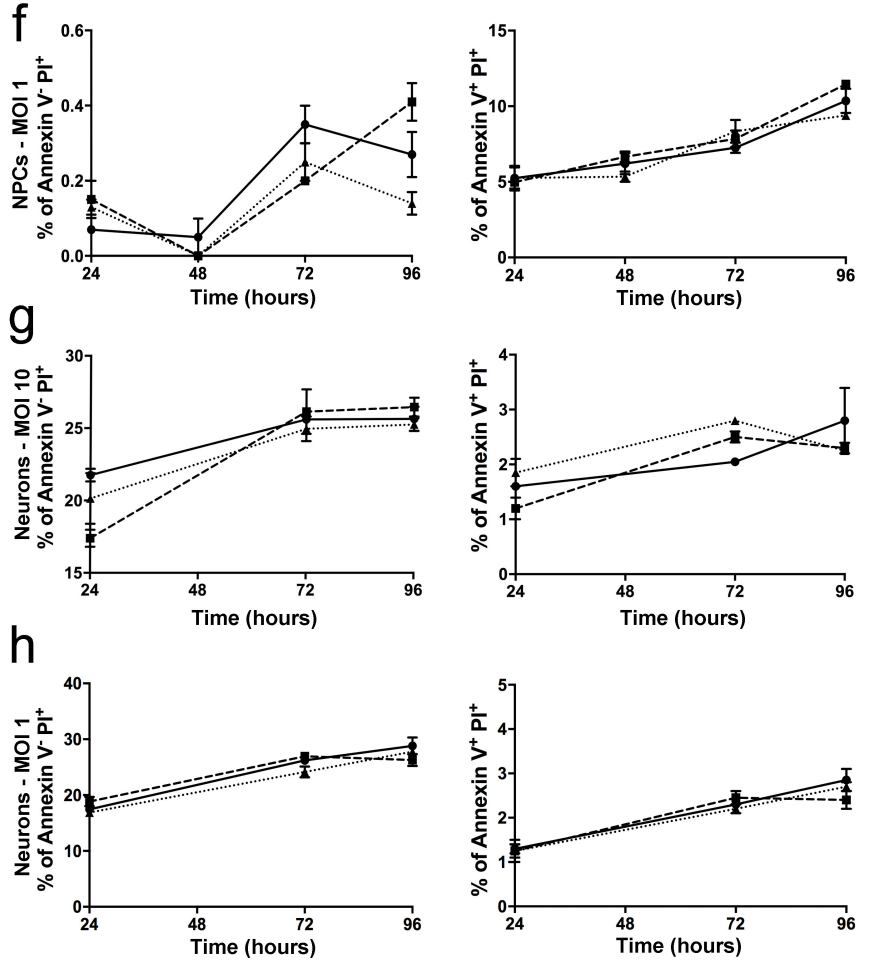
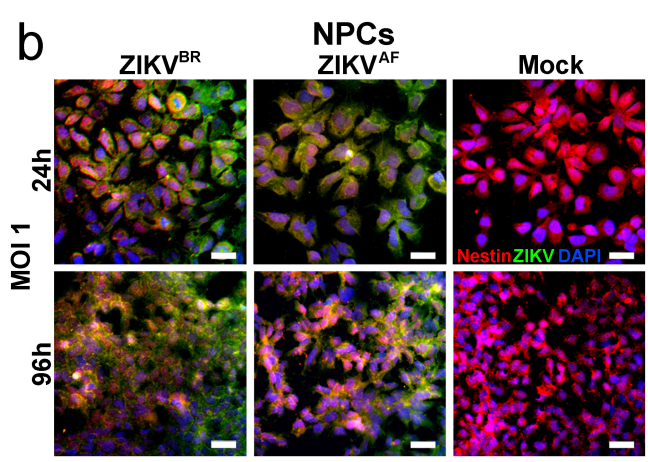

d

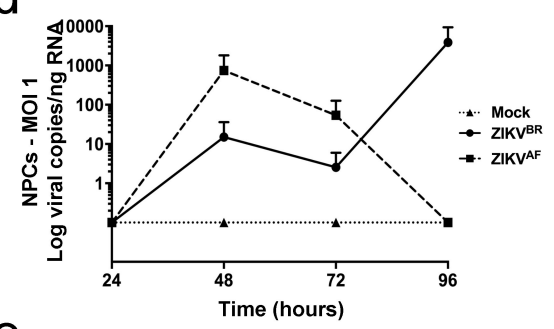

e
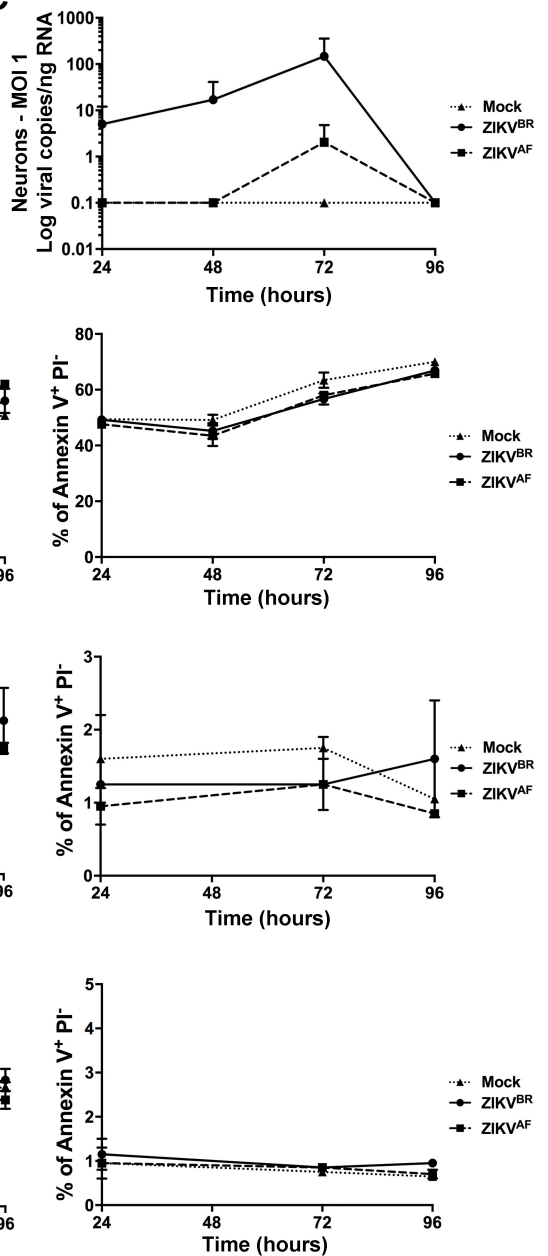

Extended Data Figure 3 Impact of ZIKV infection in human NPCs and neurons. a, Scheme of the in vitro experiments using hPSCs. The cells were differentiated into NPCs, neurons, neurospheres and cerebral organoids to test the impact of ZIKV ${ }^{\mathrm{BR}}$ over time. $\mathbf{b}$, Infection of NPCs with the $\mathrm{ZIKV}^{\mathrm{BR}}$ and $\mathrm{ZIKV}{ }^{\mathrm{AF}}(\mathrm{MOI}=1)$ at 24 and $96 \mathrm{~h}$ post-infection. Scale bar, $25 \mu \mathrm{m}$. c, Aspects of iPSC-derived human neurons after ZIKV infection $(\mathrm{MOI}=1)$ at 24 and $96 \mathrm{~h}$ post-infection. Scale bars, $200 \mu \mathrm{m}$ (bright field); $25 \mu \mathrm{m}$ (immunofluorescence). d, Viral replication dynamics in human NPCs over time $(\mathrm{MOI}=1)(n=2$ technical replicates from two different donors; error bars, s.e.m.). e, Viral replication dynamics in human neurons over time $(\mathrm{MOI}=1)(n=2$ technical replicates from two different donors; error bars, s.e.m.). f, Dynamics of NPCs toxicity over time after ZIKV infection (MOI $=1)$, indicating no significant differences among the different viruses $(n=2$ technical replicates from two different donors; error bars, s.e.m.). g, h, Viral replication dynamics of ZIKV in human neurons over time at MOI $=10$ and $\mathrm{MOI}=1$, respectively $(n=2$ technical replicates from two different donors; error bars, s.e.m.; one-way ANOVA). 
a

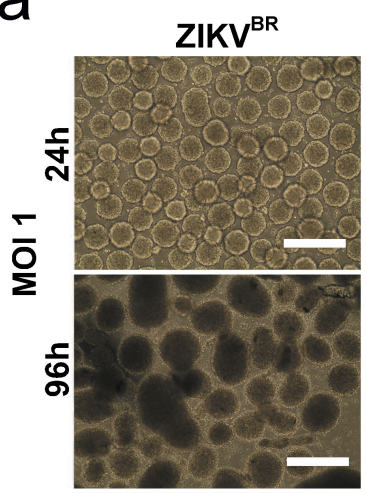

C

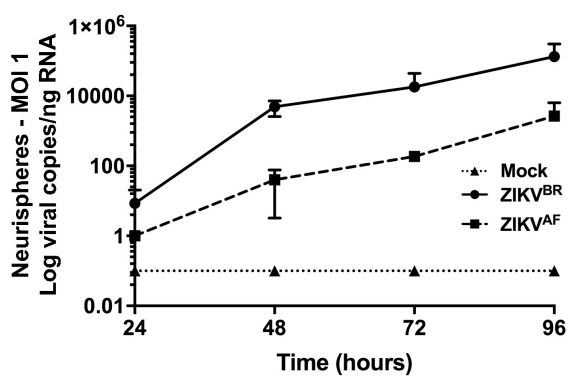

e

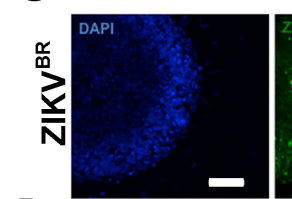

Neurospheres
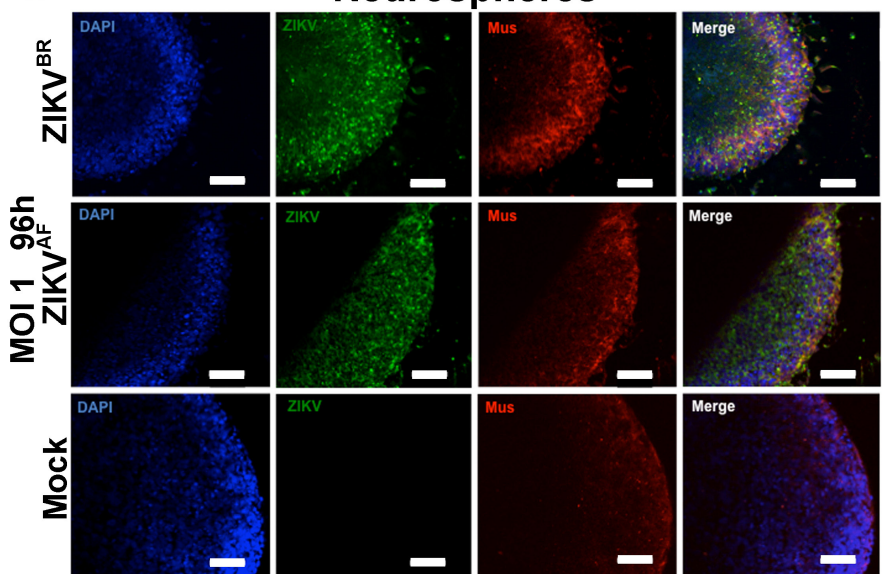

Extended Data Figure $4 \mid$ Impact of ZIKV infection in human neurospheres. a, Representative bright-field images of ZIKV infection $(\mathrm{MOI}=1)$ at 24 and $96 \mathrm{~h}$ post-infection. Scale bar, $400 \mu \mathrm{m}$. b. Alterations in neurospheres diameter over time (MOI $=1 ; n=22$ neurospheres from two different donors for each time point in each condition; error bars, s.e.m.; ANOVA, $* * * * P<0.0001)$. c, ZIKV replication dynamics in neurospheres $(\mathrm{MOI}=1 ; n=3$ technical replicates from two different b
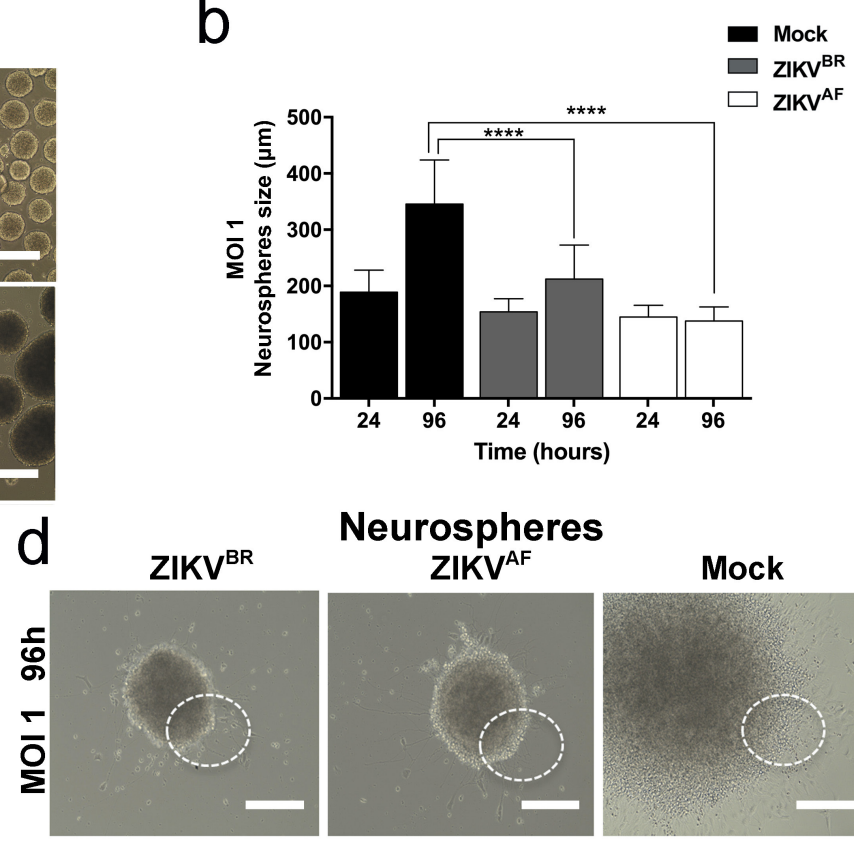

Neurospheres
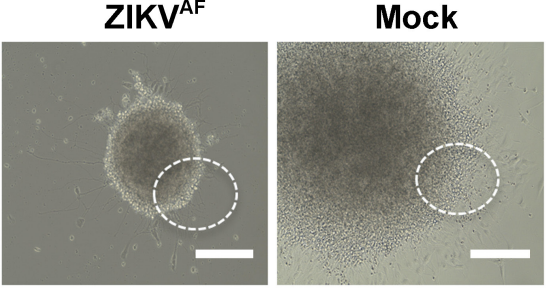

f

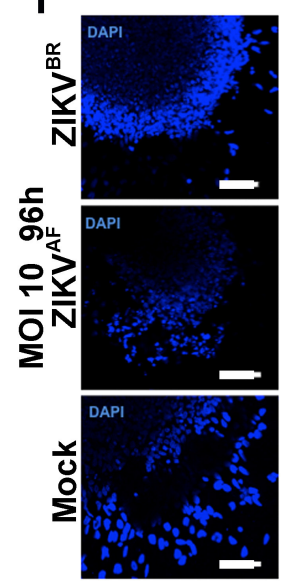

Neurospheres
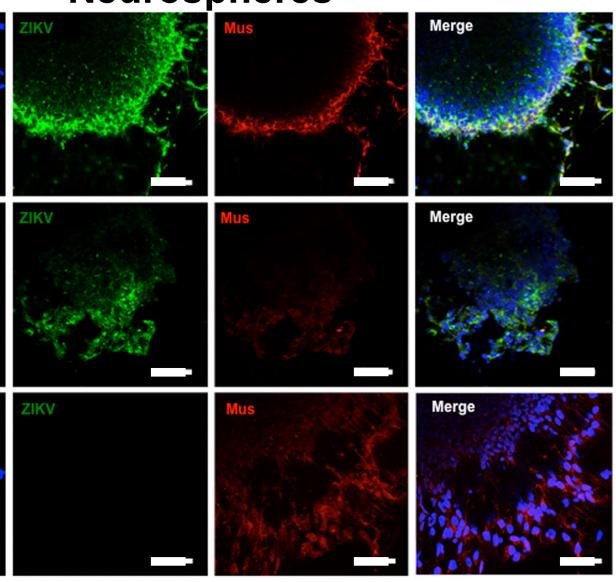

Merge

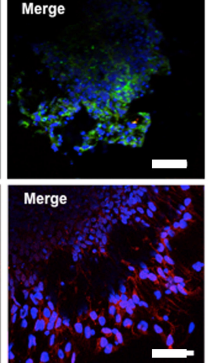

donors). d, Representative bright-field images of ZIKV infection $(\mathrm{MOI}=1)$ at $96 \mathrm{~h}$ post-infection. Scale bars, $400 \mu \mathrm{m}$ and $1,000 \mu \mathrm{m}$ (mock). The dotted circle describes the neurospheres borders indicating the immunostained regions in $\mathbf{e}$ and $\mathbf{f}$. e, $\mathbf{f}$, Immunostaining of neurospheres infected with ZIKV at $96 \mathrm{~h}$ post-infection at $\mathrm{MOI}=1(\mathbf{e})$ or $\mathrm{MOI}=10(\mathbf{f})$ revealing a qualitative reduction of proliferative cell migration from Mushashi (Mus)-positive cells. Scale bars, $50 \mu \mathrm{m}$. 


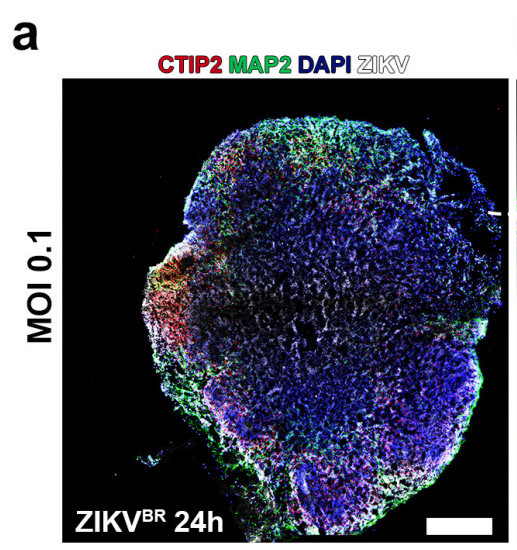

d
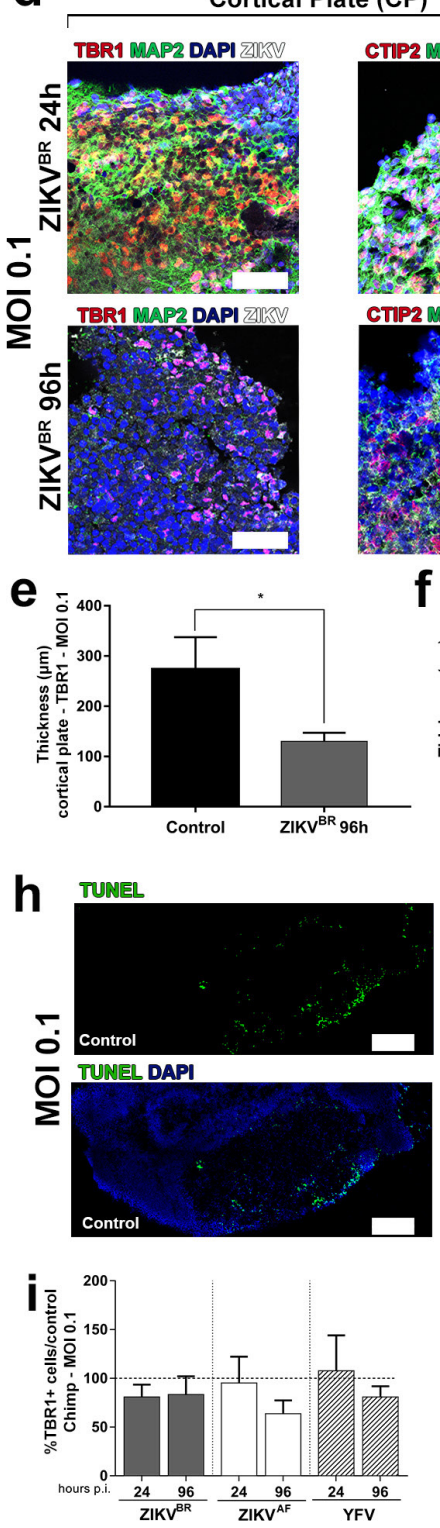

TUNEL b

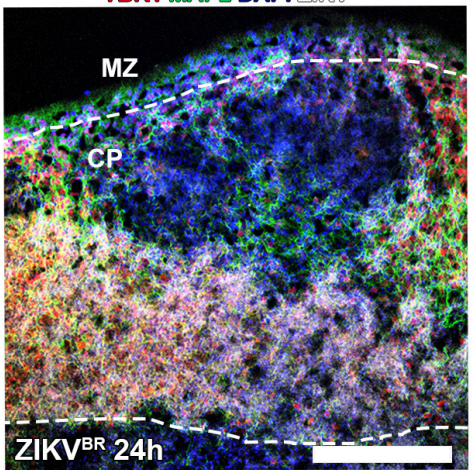

C

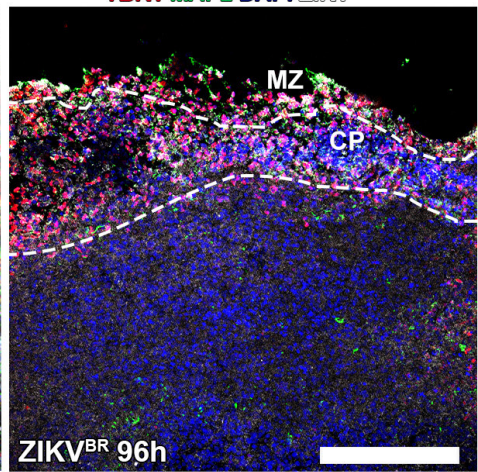

ZIKVBR $96 h$

Ventricular Zone (VZ)
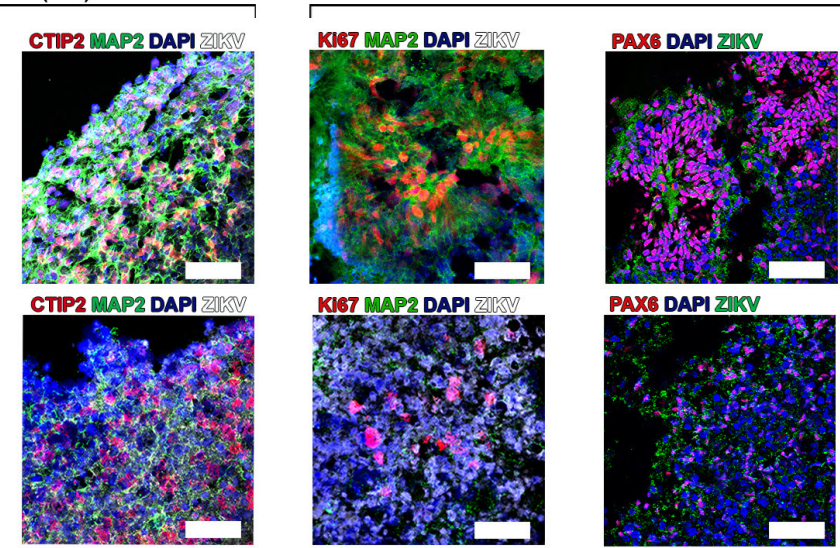

PAX6 DAPIZUKY

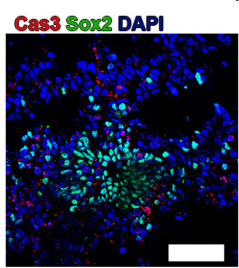

Cas3 80x2 DAPI
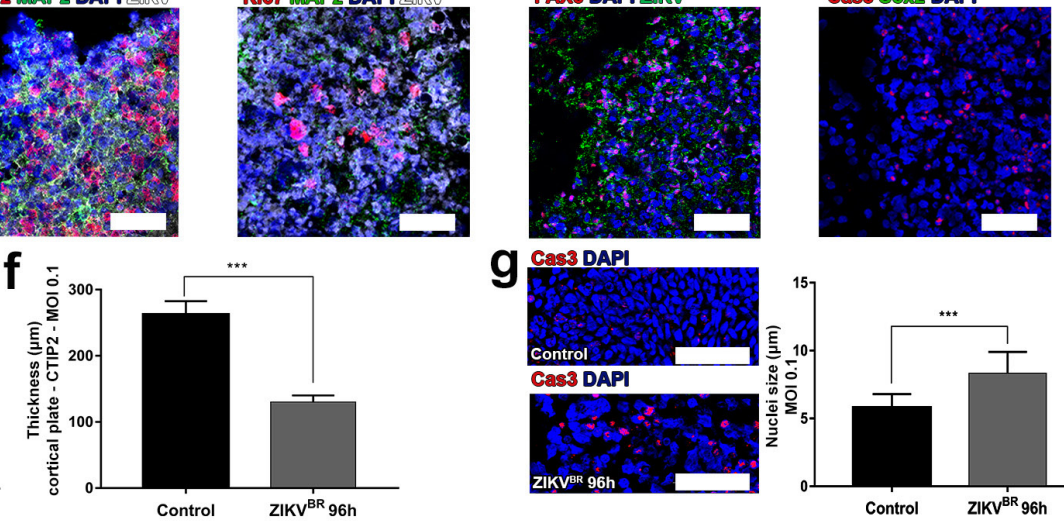

g
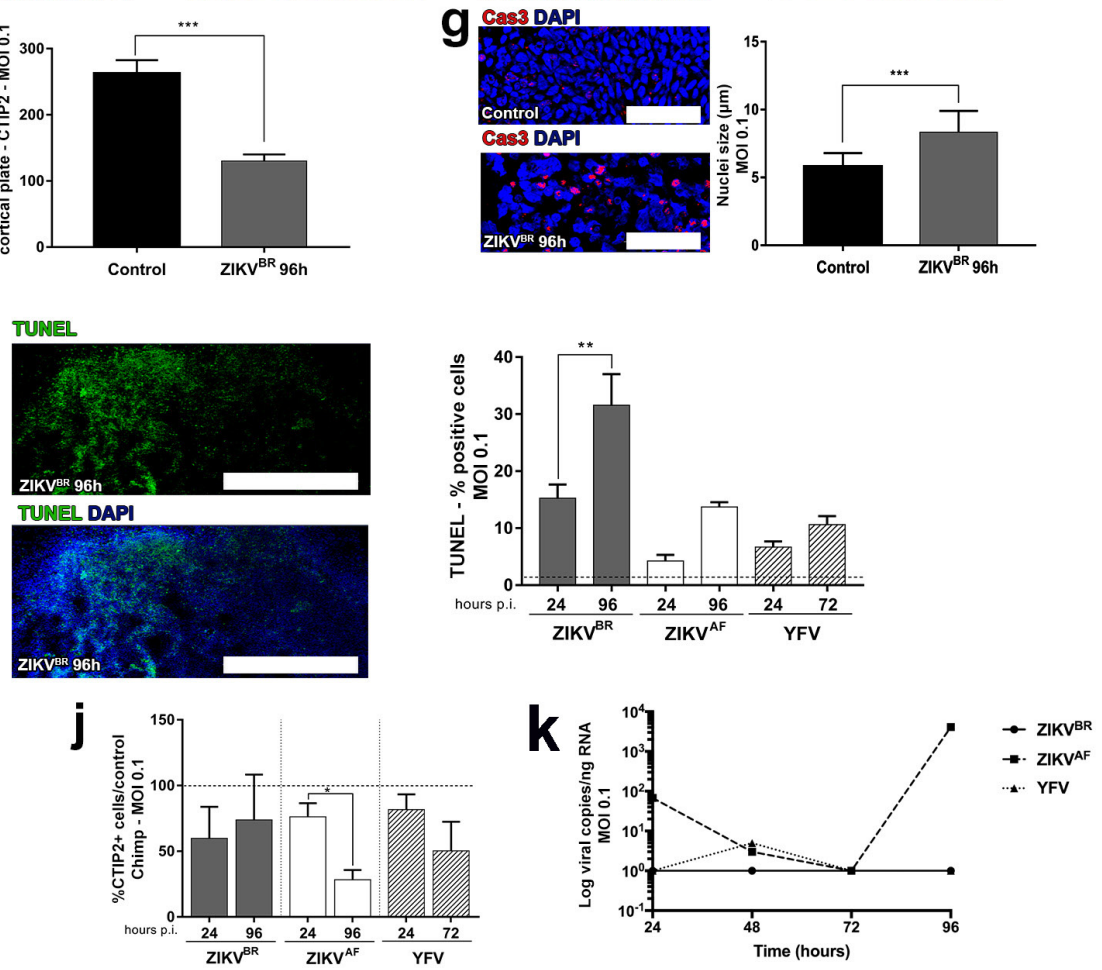

Extended Data Figure $5 \mid$ See next page for caption. 
Extended Data Figure 5 | Human and chimp cerebral organoids infected with ZIKV. a, Representative image of an entire cross-section of a cerebral human organoid infected with the $\mathrm{ZIKV}{ }^{\mathrm{BR}}(\mathrm{MOI}=0.1$, $24 \mathrm{~h}$ post-infection). Scale bar, $200 \mu \mathrm{m}$. b. Detail of the surface of a human organoid infected with the $\mathrm{ZIKV}^{\mathrm{BR}}$ at $24 \mathrm{~h}$ post-infection $(\mathrm{MOI}=0.1)$. Marginal zone (MZ) and cortical plate (CP) delineated by dotted white lines. Scale bar, $200 \mu \mathrm{m}$. c, Detail of the surface of a human organoid infected with the $\mathrm{ZIKV}^{\mathrm{BR}}$ at $96 \mathrm{~h}$ post-infection $(\mathrm{MOI}=0.1)$. Notice the significant tissue damage and reduction in the $\mathrm{CP}$ at $24 \mathrm{~h}$ postinfection. Scale bar, $200 \mu \mathrm{m}$. d, A representative characterization of CP and ventricular zone (VZ) in human organoid infected with the ZIKV $\mathrm{IR}^{\mathrm{BR}}$ at 24 and $96 \mathrm{~h}$ post-infection $(\mathrm{MOI}=0.1)$. Scale bar, $50 \mu \mathrm{m}$. e, Reduction in the cortical thickness measured by the extension of TBR1-positive layer of cells in human organoids at $96 \mathrm{~h}$ post-infection (MOI $=0.1 ; n=3$ replicates from three human cell lines; error bars, s.e.m.; unpaired $t$-test, $* P=0.0203)$. $\mathbf{f}$, Reduction in the cortical thickness measured by the extension of CTIP2-positive cells layer in human organoids at $96 \mathrm{~h}$ post-infection $(\mathrm{MOI}=0.1 ; n=3$ replicates from three human cell lines; error bars, s.e.m.; unpaired $t$-test, $* * * P=0.0005)$. g, Nuclear size (diameter) of cleaved-caspase-3-positive apoptotic cells in human organoids at $96 \mathrm{~h}$ post-infection $(\mathrm{MOI}=0.1 ; n=10$ organoids/slides from three human cell lines; error bars, s.e.m.; unpaired $t$-test, $* * * P=0.0004)$. Scale bar, $50 \mu \mathrm{m}$. h, Percentage of TUNEL-positive cells in relation to controls (dotted line) at 24 and $96 \mathrm{~h}$ post-infection (MOI $=0.1 ; n=10$ organoids/slides from three human cell lines; error bars, s.e.m.; ANOVA, $* * P=0.0042)$. i, Percentage of TBR1-positive cells in non-primate organoids (chimp) in relation to controls (dotted line) at 24 and $96 \mathrm{~h}$ post-infection (MOI $=0.1 ; n=3$ organoids from two donors, error bars, s.e.m.; ANOVA). j, Percentage of CTIP2-positive cells in non-primate organoids (chimp) in relation to controls (dotted line) at 24 and $96 \mathrm{~h}$ post-infection (MOI $=0.1 ; n=3$ organoids from two donors; error bars, s.e.m.; ANOVA). k, Viral replication dynamics in chimpanzee organoids over time (MOI $=0.1 ; n=3$ replicates from two donors; error bars, s.e.m.; ANOVA). 
RESEARCH LETTER

Extended Data Table 1 | Probes used for TAM receptors detection

\begin{tabular}{|l|l|l|}
\hline Target & Species & Code \\
\hline Tyro-3 & Human & Hs_00170723_m1 \\
\hline AxI & Human & Hs_01064444_m1 \\
\hline MertK & Human & Hs_01031973_m1 \\
\hline DC-Sign & Human & Hs_01588349_m1 \\
\hline B-actin & Human & Hs_01060665-m1 \\
\hline
\end{tabular}


Extended Data Table 2 | Antibodies used in this study, related to experimental procedures

\begin{tabular}{|l|l|l|l|l|l|}
\hline $\begin{array}{l}\text { Cell } \\
\text { type/tissue }\end{array}$ & Antigen & Host & Supplier & $\begin{array}{l}\text { Cat } \\
\text { number }\end{array}$ & Dilution \\
\hline Zika virus & ZIKV & $\begin{array}{l}\text { Mouse } \\
\text { polyclonal }\end{array}$ & $\begin{array}{l}\text { Institute } \\
\text { Pasteur in } \\
\text { Dakar }\end{array}$ & MAB10216 & $1: 50$ \\
\hline Flavivirus & Flavivirus & $\begin{array}{l}\text { Mouse } \\
\text { polyclonal }\end{array}$ & Millipore & ab5392 & $1: 200$ \\
\hline Neurons & MAP2 & $\begin{array}{l}\text { Chicken } \\
\text { polyclonal }\end{array}$ & Abcam & ab5392 & $1: 200$ \\
\hline Apoptosis & $\begin{array}{l}\text { Cleaved } \\
\text { caspase-3 }\end{array}$ & $\begin{array}{l}\text { Rabbit } \\
\text { polyclonal }\end{array}$ & $\begin{array}{l}\text { Cell } \\
\text { Signaling }\end{array}$ & 9661 & $1: 400$ \\
\hline $\begin{array}{l}\text { Progenitor } \\
\text { cell }\end{array}$ & Sox2 & $\begin{array}{l}\text { Mouse } \\
\text { monoclonal }\end{array}$ & Abcam & ab79351 & $1: 200$ \\
\hline Astrocytes & GFAP & $\begin{array}{l}\text { Rabbit } \\
\text { polyclonal }\end{array}$ & Abcam & ab7260 & $1: 500$ \\
\hline $\begin{array}{l}\text { Neuronal } \\
\text { progenitor } \\
\text { cells }\end{array}$ & Mushashi1 & $\begin{array}{l}\text { Rabbit } \\
\text { polyclonal }\end{array}$ & Abcam & ab21618 & $1: 200$ \\
\hline $\begin{array}{l}\text { Neuronal } \\
\text { progenitor } \\
\text { cells }\end{array}$ & PAX6 & $\begin{array}{l}\text { Rabbit } \\
\text { polyclonal }\end{array}$ & Covance & PRB-278P & $1: 100$ \\
\hline $\begin{array}{l}\text { Pre-plate/ } \\
\text { deep-layer } \\
\text { cortical } \\
\text { neurons }\end{array}$ & TBR1 & $\begin{array}{l}\text { rabbit } \\
\text { polyclonal }\end{array}$ & Abcam & ab31940 & $1: 400$ \\
\hline $\begin{array}{l}\text { Deep-layer } \\
\text { cortical } \\
\text { neurons }\end{array}$ & CTIP2 & $\begin{array}{l}\text { rat } \\
\text { monoclonal }\end{array}$ & Abcam & ab18465 & $1: 100$ \\
\hline $\begin{array}{l}\text { Cell } \\
\text { proliferation }\end{array}$ & Ki67 & $\begin{array}{l}\text { mouse } \\
\text { polyclonal }\end{array}$ & Covance & MMS-435P & $1: 500$ \\
\hline $\begin{array}{l}\text { Neurons } \\
\text { polyclonal }\end{array}$ & TUJ1 & Abcam & ab15580 & $1: 100$ \\
\hline
\end{tabular}




\section{SCIENTIFIC REP RTS \\ Blocking Zika virus vertical transmission}

Received: 16 June 2017

Accepted: 4 January 2018

Published online: 19 January 2018
Pinar Mesci ${ }^{1}$, Angela Macia ${ }^{1}$, Spencer M. Moore ${ }^{1}$, Sergey A. Shiryaev ${ }^{2}$, Antonella Pinto ${ }^{2}$, Chun-Teng Huang ${ }^{2}$, Leon Tejwani $\mathbb{B}^{1}{ }^{1}$, Isabella R. Fernandes ${ }^{1}$, Nicole A. Suarez ${ }^{1}$, Matthew J. Kolar $\mathbb{D}^{3}$, Sandro Montefusco ${ }^{4}$, Scott C. Rosenberg ${ }^{5,6}$, Roberto H. Herai ${ }^{7}$, Fernanda R. Cugola $\mathbb{1}^{8,9,10}$, Fabiele B. Russo ${ }^{8,9,10}$, Nicholas Sheets ${ }^{11}$, Alan Saghatelian ${ }^{3}$, Sujan Shresta ${ }^{11}$, Jeremiah D. Momper ${ }^{12}$, Jair L. Siqueira-Neto ${ }^{4}$, Kevin D. Corbett $\mathbb{(}^{5}{ }^{5}$, Patricia C. B. Beltrão-Braga ${ }^{8,9,10}$, Alexey V. Terskikh ${ }^{2}$ \& Alysson R. Muotri ${ }^{1}$

The outbreak of the Zika virus (ZIKV) has been associated with increased incidence of congenital malformations. Although recent efforts have focused on vaccine development, treatments for infected individuals are needed urgently. Sofosbuvir (SOF), an FDA-approved nucleotide analog inhibitor of the Hepatitis C (HCV) RNA-dependent RNA polymerase (RdRp) was recently shown to be protective against ZIKV both in vitro and in vivo. Here, we show that SOF protected human neural progenitor cells (NPC) and 3D neurospheres from ZIKV infection-mediated cell death and importantly restored the antiviral immune response in NPCs. In vivo, SOF treatment post-infection (p.i.) decreased viral burden in an immunodeficient mouse model. Finally, we show for the first time that acute SOF treatment of pregnant dams p.i. was well-tolerated and prevented vertical transmission of the virus to the fetus. Taken together, our data confirmed SOF-mediated sparing of human neural cell types from ZIKVmediated cell death in vitro and reduced viral burden in vivo in animal models of chronic infection and vertical transmission, strengthening the growing body of evidence for SOF anti-ZIKV activity.

The outbreak of the Zika virus (ZIKV) has been associated with an increase in newborns with congenital malformations in Brazil in the past two years ${ }^{1,2}$. A new report describing 13 infants born in Brazil between 2015 and 2016 showed that although they did not have microcephaly at birth, they subsequently had head growth deceleration to the point of microcephaly concomitant with significant neurologic abnormalities ${ }^{3}$.

Given the growing threat of ZIKV spread, some researchers have focused on prophylactic measures by screening FDA- approved drugs to repurpose for $\mathrm{ZIKV}^{4-6}$, while still other researchers worldwide have focused on vaccine development. Accordingly, a DNA vaccine to protect against ZIKV was recently proposed, with promising results in $v i v o^{7,8}$. While immunization initiatives are important, there is a need to develop clinical strategies to treat ZIKV-infected individuals, including pregnant women for whom prevention of infection is no longer an

${ }^{1}$ University of California San Diego, School of Medicine, Department of Pediatrics/Rady Children's Hospital San Diego, Department of Cellular \& Molecular Medicine, Stem Cell Program, La Jolla, CA, 92037-0695, USA. ² Sanford Burnham Prebys Medical Discovery Institute, 10901N. Torrey Pines Rd., La Jolla, CA, 92037, USA. ${ }^{3}$ Salk Institute for Biological Studies, Clayton Foundation Laboratories for Peptide Biology, Helmsley Center for Genomic Medicine, La Jolla, California, USA. ${ }^{4}$ University of California San Diego, Skaggs School of Pharmacy and Pharmaceutical Sciences, Center for Discovery and Innovation in Parasitic Diseases, 9500 Gilman Dr., La Jolla, CA, 92093, MC 0755, USA. ${ }^{5}$ Ludwig Institute for Cancer Research, San Diego Branch, 9500 Gilman Dr., La Jolla, CA, 92093, MC 2385, USA. ${ }^{6}$ University of California San Diego, Department of Cellular and Molecular Medicine, 9500 Gilman Dr., La Jolla, CA, 92093, MC 2385, USA. ${ }^{7}$ Graduate Program in Health Sciences, School of Medicine, Pontifícia Universidade Católica do Paraná (PUCPR), Curitiba, Paraná, Brazil. ${ }^{8}$ University of São Paulo, Institute of Biomedical Science, Department of Microbiology, Laboratory of Stem Cell and Disease Modeling, São Paulo, SP, 05508-000, Brazil. 'University of São Paulo, School of Arts Sciences and Humanities, Department of Obstetrics, São Paulo, SP, 03828-000, Brazil. ${ }^{10}$ University of São Paulo, School of Medicine, Center for Cellular and Molecular Therapy (NETCEM), São Paulo, SP, 01246-903, Brazil. ${ }^{11}$ Division of Inflammation Biology, La Jolla Institute for Allergy \& Immunology, La Jolla, CA, 92037, USA. ${ }^{12}$ Skaggs School of Pharmacy and Pharmaceutical Sciences, University of California, San Diego, La Jolla, CA, 92093, USA. Pinar Mesci, Angela Macia and Spencer M. Moore contributed equally to this work. Correspondence and requests for materials should be addressed to P.C.B.-B. (email: patriciacbbbraga@usp.br) or A.V.T. (email: terskikh@sbpdiscovery.org) or A.R.M. (email: muotri@ucsd.edu) 
option. Indeed ZIKV infection during the first trimester confers the greatest risk of congenital microcephaly, thus highlighting the urgent need for treatment of infected mothers?.

To provide a potential treatment against the detrimental effects of ZIKV infection we focused on testing the antiviral Sofosbuvir (SOF), a clinically-approved RNA-dependent RNA polymerase (RdRp) inhibitor, both in vitro with ZIKV-infected human neural progenitor cells (NPCs) and in vivo with mouse models. Recently, converging evidence that SOF is protective against ZIKV infection in different cell types was reported, although the precise gene expression-level events in target cells have not been described ${ }^{10-13}$. SOF is a nucleotide analog pro-drug used in combination with other drugs for the treatment and cure of chronic infection with hepatitis $\mathrm{C}$ virus (HCV), a member of Flaviviridae family ${ }^{14-18}$. Upon intracellular conversion to its active triphosphate, SOF acts on HCV by inhibiting its RNA polymerase, inhibiting replication ${ }^{14,15}$. We found that the RNA polymerases of HCV and ZIKV showed strong similarities in their active sites, and thus confirmed that SOF could also act on ZIKV-infected cells. Our data corroborated the findings of other groups ${ }^{19,20}$ and expand on these findings by showing that SOF treatment rescued apoptotic human NPCs infected with multiple ZIKV strains, both in monolayer and 3D culture. In addition, SOF also restored antiviral response gene expression in human NPCs. Furthermore; we found that SOF inhibited ZIKV more efficiently in NPCs than in Vero cells. SOF was previously shown to be protective in interferon-response compromised mouse models and in neonatal Swiss mice $^{12,13}$. To extend these findings to another animal model, we chose a mouse compromised in adaptive immunity to test SOF. We found that while the placebo group had significantly increased viral load, SOF-treated mice had reduced serum ZIKV. Finally, we tested the efficacy of SOF in blocking viral vertical transmission in the ZIKV-permissive SJL strain ${ }^{21}$. Importantly, viral burden was reduced in SOF-treated dam serum during pregnancy. Fetuses of SOF-treated dams did not show detectable ZIKV amplification, suggesting that SOF was (1) well-tolerated by ZIKV-infected SJL dams and, most importantly, (2) was able to arrest ZIKV replication in vivo in pregnant SJL females abolishing vertical transmission. The results presented here demonstrate that repurposing the FDA-approved antiviral SOF has efficacy against ZIKV in vitro and in vivo and warrants further molecular and translational investigation.

\section{Results}

RdRp domain is highly conserved between Hepatitis $C$ and Zika virus. The Flaviviridae viral family includes both HCV and ZIKV 22. Both HCV and ZIKV RdRp-encoding genes lie within NS5B and NS5 domains of the viral genome, respectively. These domains are highly conserved, especially in the active site residues, among Flaviviridae members ${ }^{8,22}$ (Fig. 1a-c). The NS5B C-terminal GDD motif catalyzes nucleotidyl transfer (Fig. 1c) and is highly conserved in Flaviviridae family (Fig. 1a-c; Supplementary Fig. 1A-B). The high sequence homology among the Flaviviridae RdRps suggests the possibility for a common target and mechanism of action. SOF is a $2^{\prime}$-modified nucleotide analog, and upon intracellular phosphorylation from its prodrug state, inhibits catalysis by incorporating into the growing RNA chain and terminating synthesis ${ }^{17}$. Since SOF-triphosphate inhibits the HCV RdRp ${ }^{14,23}$ and given the conserved structural similarities of the RdRp domain within the Flaviviridae family, we confirmed that SOF could also inhibit ZIKV replication by targeting RdRp (Fig. 1b-c). Recently, the crystal structure of the ZIKV NS5 protein was released (PDB ID: 5TFR; Longenecker, K.L., Upadhyay, A.K., Cyr, M., http://www.rcsb.org/pdb). We overlaid the ZIKV NS5 (containing the RdRp domain) structural model onto a recent structure of HCV NS5B bound to dsRNA and SOF (PDB ID 4WTG ${ }^{23}$ ) (Supplementary Fig. 1C, Supplementary Video 1). This comparison shows that the active sites of the two polymerases are indeed similar, with all residues contacting SOF conserved between HCV NS5B and ZIKV NS5. The close structural similarity suggests that SOF could interact with ZIKV NS5 and could inhibit its RNA polymerase activity (Supplementary Fig. 1C, Supplementary Video 1).

Sofosbuvir inhibits ZIKV replication in human iPSC-derived NPCs. Previous work has demonstrated that ZIKV infection slows growth of human neural progenitor cells (NPCs) and neurospheres in vitro ${ }^{21,24-26}$ and adversely affects mouse neural progenitors and radial glia ${ }^{19,27}$. To test if SOF arrests ZIKV replication, human induced pluripotent stem cell (hiPSC)-derived NPCs were chosen as the cellular model since they mimic the proliferative growth restrictions leading to microcephaly ${ }^{21}$. SOF blocked ZIKV activity with $\mathrm{IC}_{50} \mathrm{~s}$ of $13.6 \mu \mathrm{M}$ and $30.9 \mu \mathrm{M}$ in NPCs and Vero cells (used as a cell-based infection system), respectively (Fig. 2a,b). The antiviral effect of varying concentrations of SOF was further assessed in multi-step growth curves on ZIKV-infected NPCs by qRT-PCR of viral genome copies (Fig. 2C, Supplementary Table S1). Next, we evaluated whether SOF treatment could rescue the apoptotic phenotype of ZIKV-infected NPCs. NPCs were infected with ZIKV MOI 0.1 or 1,24 hours after plating and maintained 96 hours in culture. In mock-infected conditions, around $15 \%$ of cells were found to be apoptotic (Fig. 2d; Supplementary Fig. 2A-C). Upon ZIKV infection with an MOI 0.1 or 1 , the percentage of TUNEL ${ }^{+}$NPCs significantly increased to $25-40 \%$ (Fig. 2d), similarly to previous observations $^{21}$. SOF treatment in the mock-infection had no effect on apoptosis (Supplementary Fig. 2B). SOF decreased significantly the percentage of TUNEL ${ }^{+} \mathrm{NPCs}$ at different doses tested (Fig. $2 \mathrm{~d}$ ). In addition, SOF significantly decreased the expression of the early apoptotic marker, cleaved caspase 3 (CC3), in ZIKV-infected hiPSC-derived NPCs and hiPSC-derived cortical neurons, using a different viral strain with higher MOI (Brazil-ZKV 2015, MOI 10) (Supplementary Fig. 2D-F).

We next assessed the ability of NPCs to form tridimensional neurospheres upon ZIKV infection. As previously shown ${ }^{21}$, ZIKV-infected vehicle-treated neurospheres showed reduced size (diameter) and viability (number of surviving neurospheres) over time, but SOF treatment at different doses successfully rescued these phenotypes (Fig. 2e-g; Supplementary Fig. 3A-D). To measure SOF efficacy in rescuing molecular phenotypes, we measured the antiviral response gene expression signature in human NPCs in monolayer at 120 hours post-infection (p.i.) (Fig. 2h; Supplementary Fig. 3e). We found several dysregulated genes upon ZIKV infection: including but not limited to increased expression of CCL5, CXCL9, CXCL10, CXCL11, MAP2K3, IFNB1, ISG15, NLRP3 and 
a

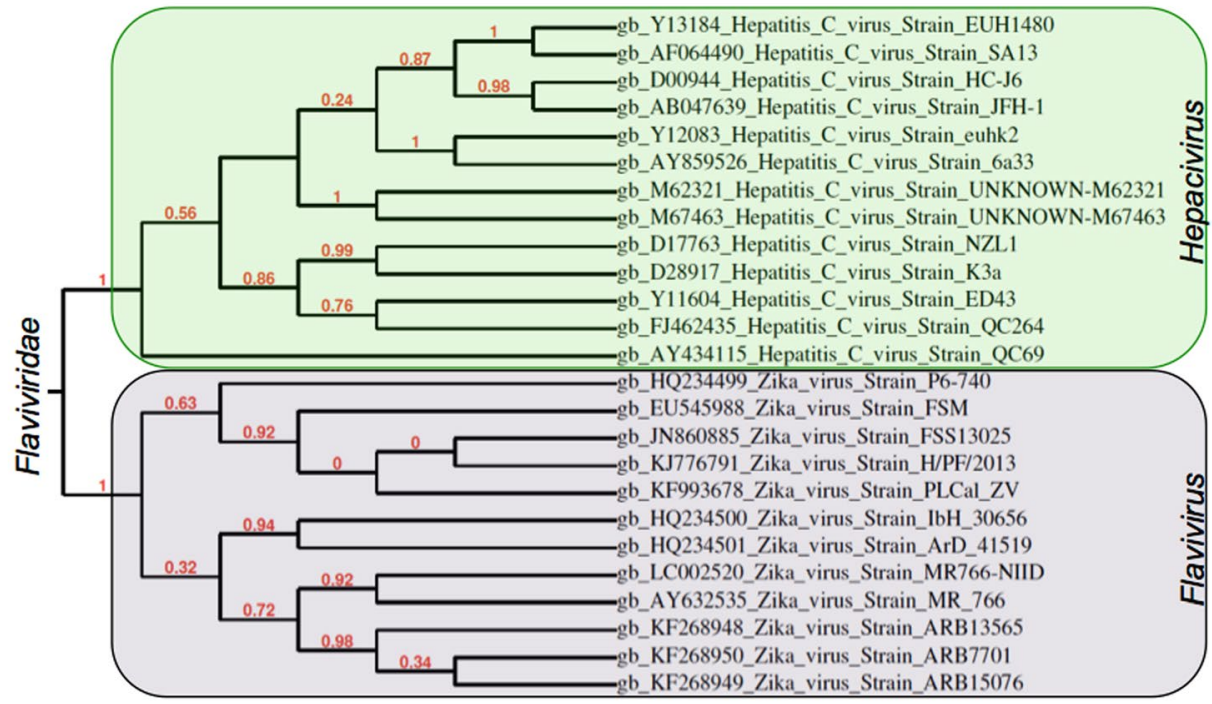

b

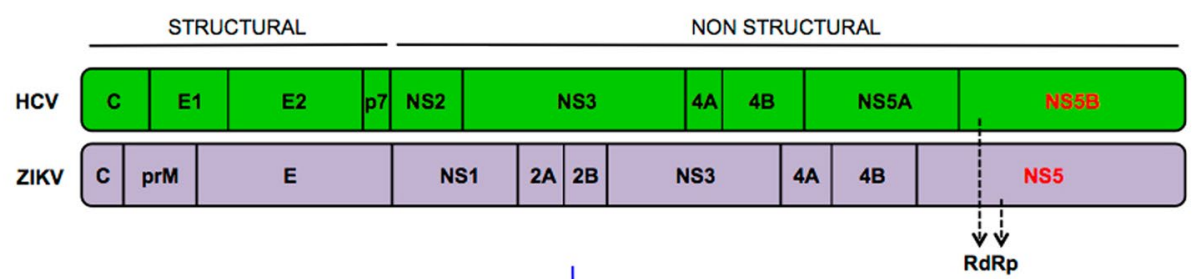

c

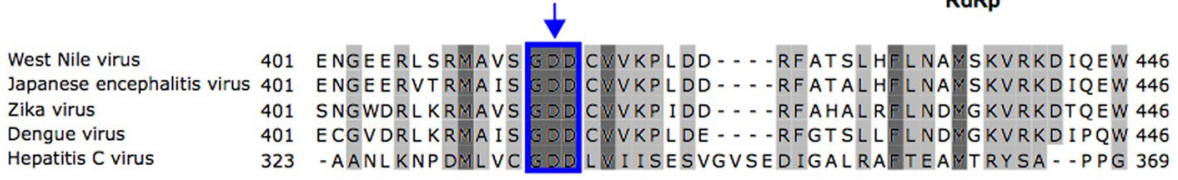

Figure 1. The RdRp domain is conserved between HCV and ZIKV. (a) Phylogenetic dendrogram showing HCV and ZIKV belonging to Hepacivirus and Flavivirus genera, respectively, within the Flaviviridae family. Phylogenetic tree of RNA polymerase domain of HCV and ZIKV strains was based on Maximum-likelihood approach. This tree is intended to highlight the degree of similarity (branch length) of the RNA polymerase from different viruses. The longer the branch is in the horizontal dimension, the larger the amount of change. The units of branch length are amino acid substitutions per site. (b) Schematic of HCV and ZIKV protein structures. Both viruses have their RNA-dependent polymerases (RdRp) within the NS5B and NS5 domains, respectively. (c) Capsid protein; prM: precursor of Membrane protein; E: Envelope protein; p7: Viroporin, NS: Non-structural proteins. (c) RNA polymerase amino acid sequence conservation and DPP domain between different members of Flaviviradae family including HCV, West Nile virus, Japanese encephalitis, Dengue virus and ZIKV. Highlighted sequences correspond to amino acid sequence conservation between strains. Light gray corresponds to amino acid conservation in 4 strains, and dark gray correspond to amino acid conservation in 5 strains (all represented strains). The blue box indicated by the arrow corresponds to the GDD amino acid domain that is conserved in all 5 represented virus strains (highlighted as dark gray).

decreased expression of IKBKB, IRAK1, PIN1, MYD88; this pattern of gene dysregulation in response to ZIKV infection serves as a biomarker, reversal of which would be a desirable attribute of efficacious therapy. SOF treatment reversed most of the dysregulation of antiviral response genes tested, showing a similar gene expression pattern between SOF-treated ZIKV-infected NPCs and mock-infected NPCs (Fig. 2h; Supplementary Fig. 3E). In conclusion, our in vitro studies suggest that SOF blocks replication of different ZIKV strains, supporting our in silico predictions and confirming previous publications $s^{10,12,28-30}$.

SOF rescues Zika viral burden in mice. Next, we assessed the efficacy of SOF in vivo. While this manuscript was under preparation, SOF was shown to protect against ZIKV in immunocompetent mice treated with an anti-IFNAR1 blocking antibody and in neonatal Swiss mice ${ }^{12,13}$, However, the first model has major limitations, as $20 \%$ of untreated ZIKV-infected mice survived, questioning the utility and efficiency of interferon (IFN)-response depleted mice to test drugs against ZIKV infections. And the second model only used neonatal pups for ZIKV infections. Thus, we chose the NOD/SCID adult immunodeficient mouse as a model for ZIKV infection (Fig. 3a). NOD/SCID mice can control the initial viral burden through an intact interferon response. However, this mouse model lacks functional $\mathrm{T}$ or $\mathrm{B}$ cells and has defective natural killer cells, a class of cytotoxic innate lymphocytes that rapidly respond to virally infected cells in the absence of antibodies, mimicking better the human condition ${ }^{31,32}$. Another advantage of the NOD/SCID model is the lack of confounding antibody 
a

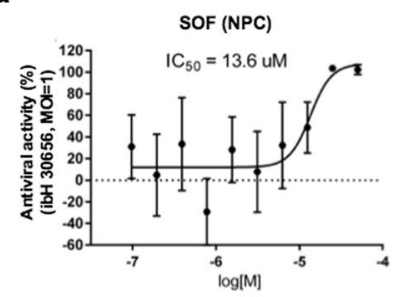

b

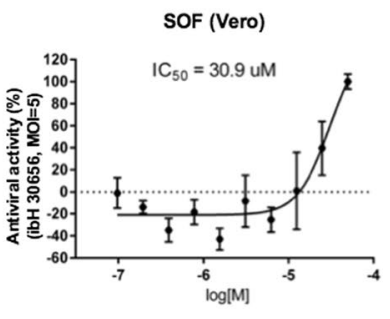

c

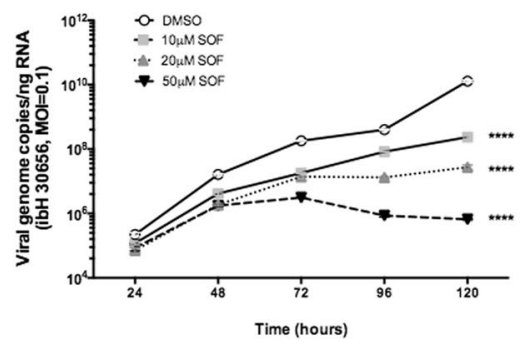

d

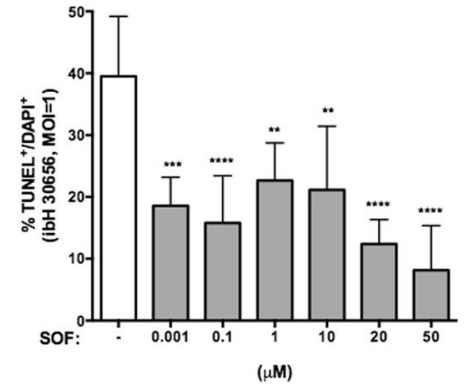

e

f
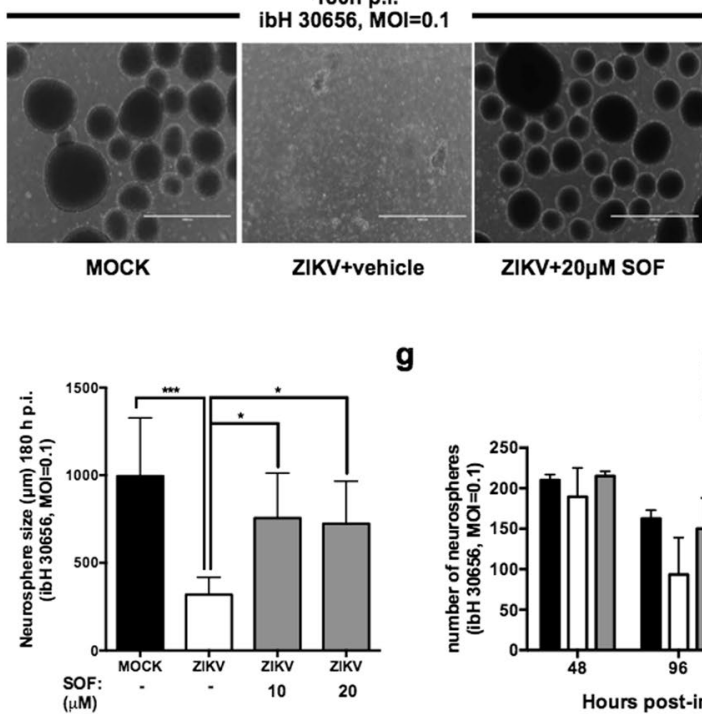

g
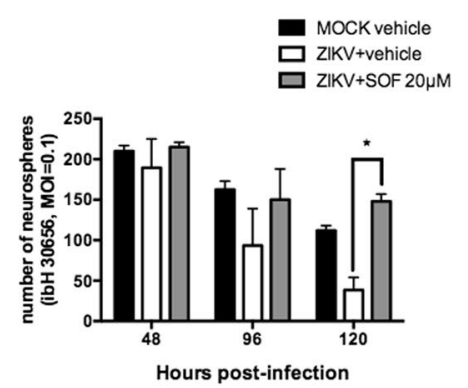

h

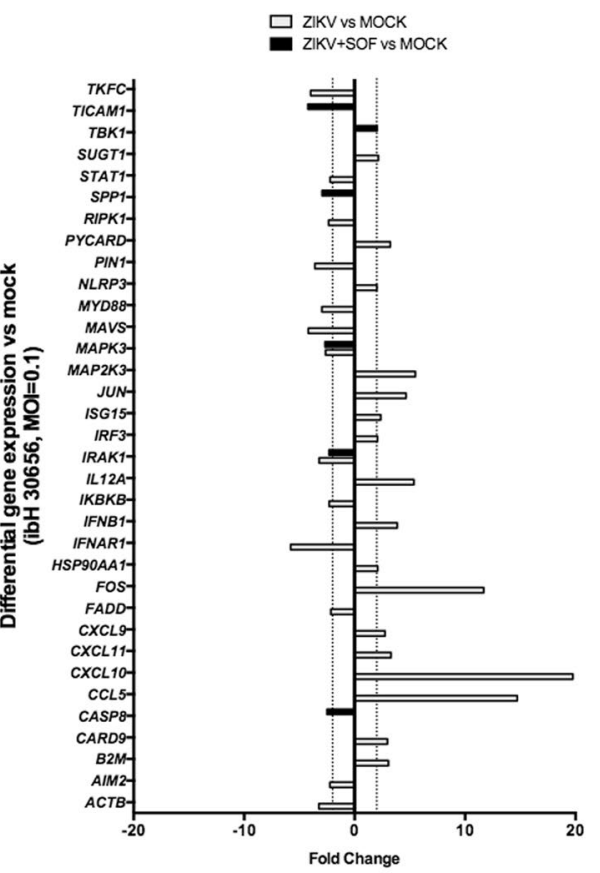

Figure 2. SOF blocks ZIKV replication in vitro. (a,b) Dose-response curves of SOF against ZIKV in NPCs and in Vero cells, respectively. SOF was tested in 10 points dose-response with two-fold dilution starting at $50 \mu \mathrm{M}$, in triplicates. The graphs show the antiviral activity (\%) based on reduction of the cytopathic effect by quantification of the cytopathic effects of ZIKV \pm SEM on NPCs (a) and Vero cells (b,c). Multi-step growth curve of vehicle or SOF-treated ZIKV-infected $(\mathrm{ibH} 30656, \mathrm{MOI}=0.1)$ NPCs at different concentrations over time as measured by viral genome copies of RNA using qRT-PCR. Data represents means $\pm \mathrm{SD}(\mathrm{n}=3$ replicates); two-way ANOVA, followed by Tukey's multiple comparison tests. $* * * * P<0.0001$ compared to DMSO (vehicle) treated NPCs at 120 hours p.i. Note that SD cannot be seen in the log scale. (d) The percentages of apoptotic cells were calculated, averaged, and graphed accordingly (ibH 30656, MOI $=0.1,96$ hours p.i.) in the presence of SOF at different doses $(1 \mathrm{nM}, 100 \mathrm{nM}, 1 \mu \mathrm{M}, 10 \mu \mathrm{M}, 20 \mu \mathrm{M}$ and $50 \mu \mathrm{M})$. One-way ANOVA tests with Tukey multiple comparisons were performed to compare to ZIKV-infected different groups. The presented values are means of TUNEL ${ }^{+} / \mathrm{DAPI}^{+}$percentage $\pm \mathrm{SD}$ ( $\mathrm{n}=6$ images per condition), $* * P<0.01$, $* * * P<0.001$, $* * * * P<0.0001 \mathrm{TUNEL}^{+} / \mathrm{DAPI}^{+}$percentage decreases with different doses of SOF. (e) Representative images of mock-infected human neurospheres (left panel), ZIKV-infected vehicle-treated neurospheres (middle panel) and ZIKV-infected SOF-treated $(20 \mu \mathrm{M})$ (right panel) neurospheres image (ibH30656, MOI =0.1, 180 hours p.i.), scale bar: $500 \mu \mathrm{m}$. (f) Quantification of neurosphere diameter $(\mu \mathrm{m})$ at 180 hours p.i. One-way ANOVA tests with Tukey multiple comparison were performed to compare different groups. The bars represent the number of spheres counted averaged and plotted for each condition $\pm \mathrm{SD}(\mathrm{n}=6$ images captured per condition), $* P<0.05$, $* * * P<0.001$ ( $\mathrm{n} \geq 100$ neurospheres counted per condition). (g) Neurosphere amount was counted over time after infection with ZIKV (ibH30656, MOI $=0.1$ at 48, 96 and 120 hours p.i.) treated with vehicle or with SOF 
$(20 \mu \mathrm{M})$. Bars represent the number of neurospheres $\pm \mathrm{SD}$ at a given time (48, 96 and 120 hours p.i.). Two-way ANOVA tests with Tukey multiple comparison were performed to compare different groups, $* P<0.05$ ( $\mathrm{n}=2$ independent experiments). (h) Human antiviral response expression signature in human NPCs in monolayer at 120 hours p.i.: mock, ZIKV-infected (ibH30656, MOI 0.1) vehicle or SOF-treated $(50 \mu \mathrm{M})($ threshold $=$ twofold). Bars represent fold changes detected by qPCR from 96 different genes tested, between ZIKV-infected compared to mock-infected NPCs (in white) and between ZIKV + SOF-treated compared to mock-infected NPCs (in black). Note that there are fewer dysregulated genes between ZIKV-infected compared to mock NPCs upon SOF treatment (less black bars) than the ZIKV-infected untreated ones.

response in testing prospective antiviral agents. A previous study compared survival after ZIKV infection in two mouse models, IFN- $\alpha / \beta$ and IFN- $\gamma$ receptor knockout AG129 and SCID ${ }^{32}$, and found that AG129 mice survived 18.5 days while SCID mice survived 40 days following an identical infection of $2 \times 10^{3} \mathrm{PFU} / \mathrm{ml}$. These data suggest that animal survival depends on the viral load and adaptive immunity and not solely IFN response ${ }^{32}$. In our study, NOD/SCID mice were infected with $10^{8}$ PFU ZIKV intravenously (IV), and started to lose weight around day 11 with mean survival of $21 \pm 3.36$ days (Supplementary Fig. 4A-C). ZIKV infected animals progressively developed severe disease requiring euthanasia (weight loss, hunched back, hindlimb paralysis). In a subsequent experiment mice were randomized to receive vehicle or SOF $50 \mathrm{mg} / \mathrm{kg} /$ day intraperitoneally (IP) beginning at day 1 p.i., for 10 days, to study antiviral activity at peak viremia ${ }^{33-35}$ (Fig. 3a). The dosage of SOF (50 mg/kg/day) used in our in vivo experiments was determined after calculating the animal equivalent dose (AED) from the recommended $400 \mathrm{mg} /$ day dose for chronic HCV infection in humans. This calculation takes into account the lower metabolic rate in larger animals, requiring a smaller drug per body weight dose among other criterion ${ }^{36}$. SOF treatment was well tolerated in mice: no marked changes in body weight (Supplementary Fig. 4D), fur, consistency of the stool or behavior (data not shown) during the treatment similar to previous work ${ }^{18}$. All mice from the ZIKV-infected vehicle-treated group had increased serum viral load, measured by plaque assays. Serum from ZIKV-infected SOF-treated mice failed to form plaques (Supplementary Fig. 4E,F). Consistently, qRT-PCR of viral RNA extracted from the serum of ZIKV-infected vehicle-treated mice revealed high levels of viral RNA. In contrast, SOF-treated ZIKV-infected mice had significantly less ZIKV RNA (Fig. 3b, Supplementary Table S2).

SOF is indicated for oral (PO) administration in humans. In healthy subjects administered the clinical SOF dose of $400 \mathrm{mg}$ PO daily, average steady state concentrations of the predominant circulating metabolite GS-331007 were $463 \mathrm{ng} / \mathrm{mL}^{37}$. Hence, we considered whether SOF exposure depends on route of administration (PO versus IP). We delivered $50 \mathrm{mg} / \mathrm{kg} /$ day SOF to naïve mice daily for 4 days by IP or PO (Supplementary Fig. 4G) After 4 days, sera were extracted and subjected to liquid chromatography/mass spectrometry analysis, demonstrating average minimum serum concentrations $\left(\mathrm{C}_{\min }\right)$ of the predominant circulating metabolite GS-331007 of 608 and $588 \mathrm{ng} / \mathrm{mL}$ in the IP and PO-treated groups, respectively, with no significant differences between groups, suggesting that SOF has antiviral activity against ZIKV at concentrations that have been shown to be safe in humans. Indeed, when we repeated the initial experiment with NOD/SCID mice infected with ZIKV to compare the efficacy of PO versus IP, both delivery routes significantly decreased viremia after 10 days in a similar fashion (Fig. 3c).

Finally, as the abolition of vertical transmission is of critical interest in the context of congenital ZIKV infection, we tested the efficacy of SOF to block ZIKV vertical transmission in the ZIKV-permissive SJL strain ${ }^{21}$. Pregnant females were infected with $2 \times 10^{5} \mathrm{PFU}$ (Asian ZIKV strain PA 259459) at embryonic day (E) 12.5 as previously described ${ }^{38}$. Dose and timing of the viral inoculum were selected based on our previous publication and caused a similarly robust ZIKV infection of SJL dams, corroborating previous work ${ }^{38}$. The viral inoculation dose was selected as comparable to vector-borne inoculation ${ }^{39}$ (Fig. 3d; Supplementary Fig. 4A). The mice were randomized to receive $50 \mathrm{mg} / \mathrm{kg}$ /day of SOF or vehicle PO from E13.5-E18.5, when they were euthanized and the fetuses extracted (Fig. 3d). The viral RNA was detected in all vehicle-treated dam sera at E18.5, and in heads of their respective fetuses (Fig. 3e). Immunohistochemistry against Flavivirus Group Antigen in brain cross-sections of E18.5 embryos coming from SOF-treated dams showed a reduction of ZIKV compared to fetuses from VEH-treated dams (Fig. 3f,g). In addition, no obvious congenital malformations or weight loss were detected between fetal groups at this stage when infected with ZIKV at $2 \times 10^{5} \mathrm{PFU}$ (Supplementary Fig. $4 \mathrm{H}$ ). The viral burden was significantly reduced in SOF-treated dam serum at E18.5 (Fig. 3h). Fetuses of SOF-treated dams did not show any detectable ZIKV amplification, suggesting that SOF was (1) well-tolerated by ZIKV-infected SJL dams and, most importantly, (2) was able to arrest ZIKV replication in vivo in pregnant SJL females abolishing vertical transmission.

\section{Discussion}

Here we obtained similar results regarding the reduction in ZIKV infection-induced cell death in a 2D model, and a rescue of ZIKV-mediated decreased neurosphere size in 3D cultures with SOF treatment, adding to the mounting evidence that SOF can act against ZIKV ${ }^{10,12,28-30,40}$. In addition, we show that treatment with SOF further restored the antiviral response gene expression signature of ZIKV-infected NPCs. We also tested SOF in an in vivo immunodeficient mouse model. SOF treatment reduced serum ZIKV burden in all treated mice. Importantly, we show here for the first time that SOF was also well tolerated in pregnant dams and abolished vertical transmission of ZIKV to the fetuses.

The prevailing ZIKV model describes a causal relationship between maternal infection, neonatal microcephaly and motor defects manifesting several months after birth ${ }^{41}$, thus implicating vertical transmission ${ }^{21,27}$. Therefore, effective treatment must focus on reducing viral replication in pregnant women and thus the risk of vertical transmission to the fetus. However, it is still unclear how vertical transmission occurs in vivo. Recently, we 
a

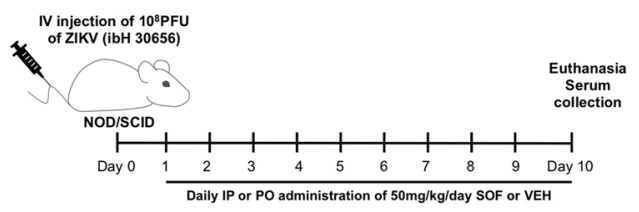

b

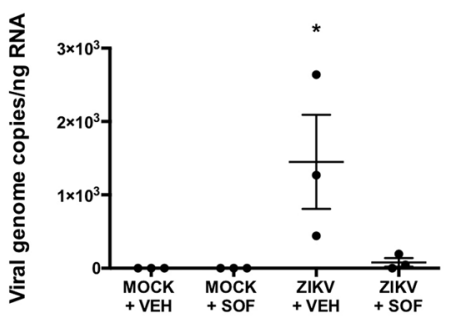

C

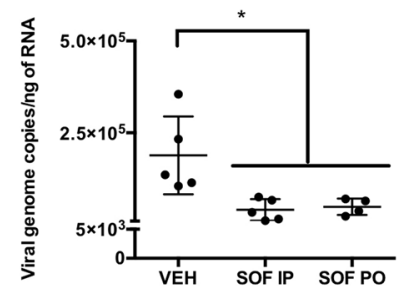

d

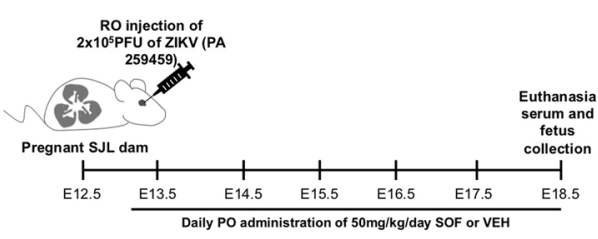

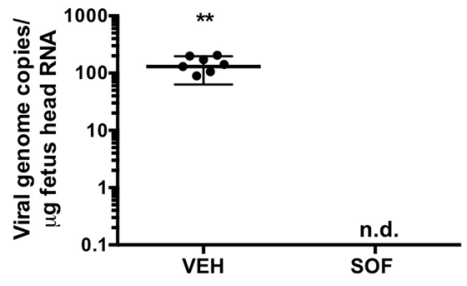

f

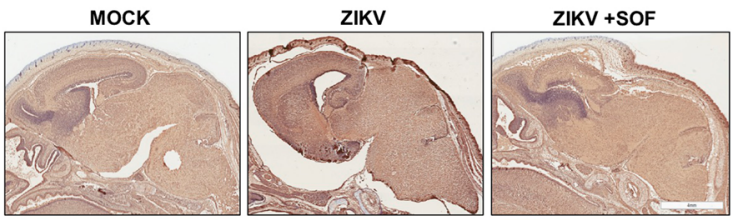

g

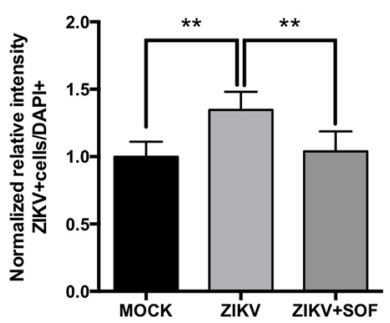

h

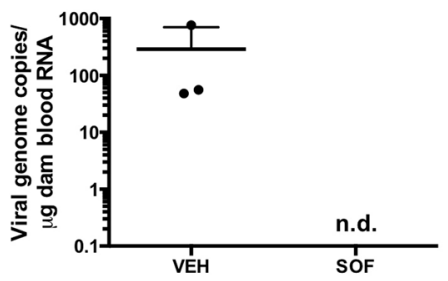

Figure 3. SOF blocks ZIKV replication in vivo. (a) Schematic of the experimental design for mice infection: 8 weeks-old NOD/SCID female mice were intra-venously injected with $10^{8} \mathrm{PFU}$ of ZIKV (ibH 30656). One day p.i. mice were randomized to receive either vehicle or SOF at $50 \mathrm{mg} / \mathrm{kg} /$ day IP or PO. (b) RNA viral load was measured in the serum of infected mice by qRT-PCR. One-way ANOVA tests with Tukey multiple comparison were performed to compare to MOCK-vehicle (VEH) group, ${ }^{*} P<0.05(\mathrm{n}=3$ technical replicates, $\mathrm{n}=3$ mice per group). Each dot represents the average of $n=3$ technical replicates per mouse \pm SEM. (c) RNA viral load was measured in the serum of infected mice by qRT-PCR. Each dot represents a mouse: vehicle $\mathrm{n}=5 \mathrm{mice}$, SOF IP $\mathrm{n}=5$ mice, SOF PO $\mathrm{n}=5$ and monitored for 10 days before euthanasia and blood collection. Oneway ANOVA tests with Tukey multiple comparison were performed to compare to vehicle group, $* P<0.05$. Bars represent $\pm S D$. (d) Schematic of the experimental design for infection of SJL pregnant mice. SJL dams were ZIKV-infected (PA 259459) with $2 \times 10^{5} \mathrm{PFU}$ at E12.5. At E13.5, they were randomly assigned to receive vehicle or SOF (50 mg/kg/day) PO. At E18.5, mice were euthanized for blood and fetus collection. (e) RNA viral load was measured in the fetus heads mice by qRT-PCR. Each dot represents a fetus head (vehicletreated $\mathrm{n}=8$ pooled from 3 independent litters, 1 did not amplify and SOF-treated, $n=6$ fetus heads from 3 independent litters). Student's t-test was performed to compare the two groups; Bars represent the average viral load $\pm \mathrm{SD}(* * P<0.01)$, n. d. = not detected. (f) Immunohistochemistry against Flavivirus Group Antigen (brown) and counterstained in Mayer's hematoxylin (blue) in brain cross-sections of E18.5 fetuses from mockinfected, ZIKV-infected vehicle-treated, or ZIKV-infected, SOF-treated dams. Scale bars $4 \mathrm{~mm}$. (g) All data are represented as mean $\pm S D$ ( $n=6$ per condition: 3 embryos, 2 slides each embryo per condition) and were analyzed with one-way ANOVA (Turkey's Multiple Comparison post test). $* * P<0.01$. (h) RNA viral load was measured in the dam serum by qRT-PCR. Each dot represents one mouse \pm SD (vehicle-treated $n=3$ and SOFtreated, $\mathrm{n}=3)$. $\mathrm{n}$. $\mathrm{d}$. = not detected. Student's t-test was performed to compare the two groups $(P=0.2902)$.

generated hiPSC-derived microglia and NPCs to mimic and study the neuro-immune interactions during embryogenesis $^{29}$. Microglia, the macrophages of the central nervous system (CNS), are generated in the yolk sac and invade the brain during embryogenesis to become resident macrophages ${ }^{42}$. Given the timing of their invasion, 
microglia could spread the virus in the developing brain during its CNS infiltration acting as a Trojan horse ${ }^{29}$. We found that microglial cells could indeed transmit ZIKV to NPCs in vitro and importantly, when microglia-NPC co-cultures were treated with SOF, ZIKV infection of NPCs was limited ${ }^{29}$. Although out of scope of the present study, one limitation of our work is the lack of congenital disease, showing that SOF treatment can prevent birth defects in the newborn pups. To this end, a recent study treated neonatally ZIKV-infected pups with SOF and showed that short- and long-term sequelae could be prevented ${ }^{13}$, thus supporting our hypothesis regarding the benefits of SOF treatment of ZIKV- infected pregnant women. Future studies should focus on the treatment of congenital disease using SOF and analysis of other tissues such as placenta, spleen, thymus etc. Taken together with our current study, there is strong converging evidence that SOF is a reasonable option to block vertical transmission, possibly acting by limiting the infection of microglia thus restricting viral spread to the fetal brain. SOF is labeled as FDA pregnancy category B, indicating that while no controlled studies have been conducted in pregnant women receiving the drug, animal studies have not demonstrated risks to the fetus ${ }^{16,18}$. Indeed, a clinical trial has recently commenced recruiting pregnant women with chronic HCV (NCT02683005) to study the effects of SOF during pregnancy. Comparable nucleotide/nucleoside analog antivirals such as acyclovir (herpes simplex virus) and the HIV anti-retrovirals are routinely used during pregnancy to prevent perinatal transmission and have not shown elevated risks of birth defects ${ }^{43,44}$. The placental transfer and tissue distribution of SOF and related metabolites was previously evaluated using quantitative whole body autoradiography in pregnant female rats administered a single $20 \mathrm{mg} / \mathrm{kg}$ oral dose of ${ }^{14} \mathrm{C}$-sofosbuvir ${ }^{45}$. Importantly, SOF-derived radioactivity was detected in fetal brain with exposures that were 5-fold higher than those observed in pregnant dams at 24 hours post-dose. This finding indicates that SOF may have sufficient brain penetration to inhibit viral replication in the developing fetal brain while also achieving systemic exposure necessary to block replication at other sites. No deleterious SOF effects on fetal development have been observed at the highest doses tested in gestating rats and rabbits (Gilead Sciences). Interestingly, a study showed that SOF delivered at $44 \mathrm{mg} / \mathrm{kg} / \mathrm{d}$ or $440 \mathrm{mg} / \mathrm{kg} / \mathrm{d}$ for 14 days did not cause liver toxicity in the chimeric TK-NOG mice with humanized livers ${ }^{18}$. Pregnancy category B states a treatment should be used during pregnancy only if the potential for benefit justifies the potential risk to the fetus ${ }^{46}$. However, in pre-clinical reproduction toxicity studies, SOF had no effects on embryo-fetal and pre-and post-natal development at exposures at least 10-fold greater than the mean clinical exposure at the approved SOF dose of $400 \mathrm{mg}$ (Sofosbuvir For Treatment of Chronic Hepatitis C Infection Antiviral Drugs Advisory Committee Meeting Briefing Document, Gilead Sciences, 2013). Moreover, SOF has been shown to be brain and placenta-penetrant ${ }^{47}$. In line with this, our data indicate that SOF abolishes vertical ZIKV transmission in pregnant immunocompetent mice. Although the animal dosages $(50 \mathrm{mg} / \mathrm{kg})$ used experimentally exceed the human dose ( $400 \mathrm{mg}$ ) by weight, species scaling by body surface area corresponds to a scaled human equivalent dose (HED) of $4 \mathrm{mg} / \mathrm{kg}$, less than the human SOF dose for a $70 \mathrm{~kg}$ individual ${ }^{36}$. Therefore, our results suggest that SOF used as a treatment for ZIKV could be prescribed at the same dosage as it is used for HCV patients.

Finally, in addition to the risks in pregnant women, in adults, a high incidence of Guillain-Barré syndrome has been linked to ZIKV infection ${ }^{48}$, as well as other ZIKV-infection sequelae, which include meningoencephalitis ${ }^{49}$, uveitis $^{50}$, and acute myelitis ${ }^{51}$. It is possible that other clinical manifestations of ZIKV infection will surface in the near future. Given our results, treatment with SOF could also arrest or help to prevent the development of other clinical manifestations observed in adults.

Research in the use of nucleotide/nucleoside analog inhibitors to combat ZIKV infection has accelerated in the last year, with demonstrated antiviral activity among $2^{\prime}-C$-methylated nucleosides in cultured Vero cells and in a mouse model ${ }^{32,52}$. In this study, we took advantage of the similarities between the RdRp domain of HCV and ZIKV and hypothesized that SOF; an FDA-approved drug indicated for treatment of chronic HCV infection, could also arrest ZIKV replication. Our work and others' recently published studies, have shown SOF to be protective against different strains of ZIKV including the strain isolated from a microcephalic case in Brazil, used in the present study along with others. However, both our work and that of others have found a higher $\mathrm{IC}_{50}$ of SOF against ZIKV when compared to HCV. Interestingly, we found the IC $_{50}$ of SOF against ZIKV in human NPCs to be lower than in Vero cells, suggesting greater potency in this cell type. Nonetheless, our calculated $\mathrm{IC}_{50}$ values against SOF suggest reduced potency against ZIKV versus HCV. This is perhaps not surprising given that SOF was initially designed for chronic HCV infection targeting the liver - a different virus and different cell type versus our models, thus highlighting potential cell-type specific differences in drug metabolism ${ }^{37}$ (Sovaldi ${ }^{\circledR}$ Full Prescribing Information, Gilead Sciences, Inc, 2013). Other SOF analogs tested both in vitro and in vivo have shown greater potency than $\mathrm{SOF}^{32,52,53}$. Future research should focus on developing ZIKV-specific SOF analogs. Nonetheless, currently SOF remains the only FDA-approved drug readily available and is still protective against $Z I K V$ as we and other groups have shown ${ }^{10-13,52,53}$. SOF regimen for HCV infection is very costly in the United States, though it is less expensive in low-income countries such as Brazil, and a generic version could address the imminent public concern of the Zika outbreak. However, although the cost of SOF regimen is lower in developing countries, it still remains out of reach for many individuals in low-income areas to treat HCV-infected patients, making it even more challenging to treat ZIKV-infected individuals. Thus, there is an urgent need to make SOF less costly worldwide, which could increase assistance to HCV- and ZIKV-infected patients. Thus, our results warrant further study of the immediate application of SOF treatment to ZIKV-infected adults since no other treatments are currently available.

In conclusion, our data illustrate the advantage of immediate translational potential through repurposing the nucleotide analog SOF that is already in wide clinical use for chronic HCV infection. In the wake of limited outcome data available for long-term effects of congenital ZIKV and no therapeutic options, multiple basic and translational options merit investigation. Our data strengthen the body of evidence for targeting ZIKV replication with nucleotide analog RNA-polymerase inhibitors in general, and SOF in particular. These promising data warrant further preclinical studies of SOF to insure efficacy and safety for congenital ZIKV infection. 


\begin{abstract}
Materials and Methods
Animals. Nod.Scid. 8-week-old NOD/SCID (NOD.CB17-Prkdc $<$ scid $>/$ J) mice were purchased from the Jackson Laboratory. Mice received a single intra-venous (IV) injection of $100 \mu \mathrm{l}$ ZIKV-infected (ibH 30656) Vero cell supernatant containing $10^{8}$ PFU on day zero ( $\mathrm{n} \geq 6$ mice). The mouse groups were randomized and experimenters were blinded to group assignment and treatment. The control group received a single IV injection of $100 \mu \mathrm{l}$ of filtered conditioned media from uninfected Vero cells, used as mock-infection ( $\mathrm{n}=6$ mice). Of note, no signs of inflammation that could be attributable to any floating cells captured in the conditioned medium was observed in mock-infected mouse group. The mock-infected animals failed to display any observable side effects from the mock-infection including changes in weight, gross locomotor activity or fur consistency. The next day, infected mice received an intra-peritoneal (IP) injection or oral gavage (PO) of $50 \mathrm{mg} / \mathrm{kg} / \mathrm{day}$ of SOF (Acme Biosciences, Palo Alto, CA) (diluted in vehicle: DMSO and Tween $80(0.5 \% \mathrm{v} / \mathrm{v}) /$ polyethylene glycol-400 $(49.5 \%$ $\mathrm{v} / \mathrm{v})$ for IP and PO respectively) $(\mathrm{n}=3)$, and the placebo group received only vehicle $(\mathrm{n}=3)$. Although the animal dosages $(50 \mathrm{mg} / \mathrm{kg})$ used experimentally exceed the human dose $(400 \mathrm{mg})$ by weight, species scaling by body surface area corresponds to a scaled human equivalent dose (HED) of $4 \mathrm{mg} / \mathrm{kg}$, less than the human SOF dose for a $70 \mathrm{~kg}$ individual ${ }^{36}$. Mice were injected with SOF and monitored daily for 10 days. On day 11, mice were euthanized and blood was collected for downstream applications. All animal procedures were approved by the Institutional Animal Care and Use Committee (IACUC) of the University of California. All procedures followed institutional guidelines. For survival experiments, end stage was defined when the mouse had lost $20 \%$ of their initial body weight and therefore needed euthanasia.
\end{abstract}

Infection of SJL pregnant dams. Timed pregnant (E12.5) SJL mice 2-3 month of age (Jackson Laboratories, Bar Harbor, ME, USA) were infected intravenously (retro-orbital injection, RO) with $200 \mu$ l of ZIKV (strain PA 259459) containing $2 \times 10^{5}$ PFU of virus particles as previously described ${ }^{38}$. This dose and timing of the infection during pregnancy was sufficient to cause a robust ZIKV infection in SJL mice ${ }^{38}$. SOF $(50 \mathrm{mg} /$ $\mathrm{kg}$ ) was delivered daily by oral gavage for six days (E13.5-18.5). The animals were euthanized to obtain fetal tissues and collect blood samples from mothers. All the experiments were performed with the approval of the Sanford Burnham Prebys Medical Discovery Institute IACUC Committee protocol AUF\#16-049.

ZIKV NS1 ELISA. A monoclonal antibody-based enzyme-linked immunosorbent assay (ELISA) was performed for the quantitative detection of the Zika Virus nonstructural protein NS1 (BioFront Technologies). Briefly, cell culture supernatants from ZIKV strains ibH 30656, and PA 259459 were collected, lysed, clarified and further incubated in a ZIKV NS1 ELISA assay plate. Anti-NS1 HRP-conjugate and HRP substrate were used as detection method. After adding the quenching solution, absorbance values were acquired $(450 \mathrm{~nm})$ and analyzed using a standard curve generated from recombinant Zika Virus (rZIKV) NS1 protein.

Real-time PCR from the NOD/SCID mice samples. Following euthanasia, whole blood of each mouse was collected and allowed to coagulate at RT for 30 minutes. After coagulation, the blood was centrifuged at $16,000 \times g$ for 10 minutes for separation of the serum $(\sim 150 \mu \mathrm{l}$ of serum per mouse). The serum volume was divided into two tubes: (1) to treat the Vero cells for plaque assay and (2) for RNA extraction. To extract the RNA from the serum, QIAamp viral RNA isolation kit (Qiagen) was used according to the manufacturer's instructions. A total of $250 \mathrm{ng}$ of total RNA was reverse transcribed using QuantiTect Reverse Transcription Kit (Qiagen) including a step of genomic DNA wipe out. Approximately $15 \mathrm{ng}$ of cDNAs were used per reaction and PCRs were carried out in a final volume of $20 \mu \mathrm{l}$. Triplicate samples were analyzed in a CFX96 Touch Real-Time PCR Detection System (Bio-rad) using $\mathrm{iQ}^{\mathrm{TM}} \mathrm{SYBR}^{\circledR}$ Green Supermix (Bio-rad). The run method was as follows: 3 minutes at $95^{\circ} \mathrm{C}, 42$ cycles of 10 seconds at $95^{\circ} \mathrm{C}$ followed by 30 seconds at $58^{\circ} \mathrm{C}$, and a melting curve was performed to confirm the identity of the amplified product. The primers used are ZIKVF9027: CCT TGG ATT CTT GAA CGA GGA; ZIKVR9197c: AGA GCT TCA TTC TCC AGA TCAA, as previously reported ${ }^{54}$. In all cases, the standard curve method was used for quantitative analysis of expression levels, based on serial dilutions of PCR product amplification of the ZIKV genome.

Real-time PCR from the SJL mice samples. $\quad 100 \mu \mathrm{l}$ of blood samples were obtained from the pregnant (E18) SJL mice. The RNA was extracted from each sample using the NucleoSpin RNA Kit (Macherey-Nagel $\mathrm{GmbH}$, Duren, Germany) accordingly to the manufacturer's instructions. Purified RNA samples were quantified using NanoDrop spectrophotometer (NanoDrop Technologies, Wilmington, DE, USA) and stored at $-80^{\circ} \mathrm{C}$. All real-time assays were performed by using the QuantiTect Reverse Transcription Kit (QIAGEN, Valencia, CA, USA) with amplification in the LightCycler 480 II instrument (Roche, Indianapolis, IN, USA) following the manufacturer's protocol.

The real-time reaction was performed in triplicates with the LightCycler 480 SYBR Green I Master Mix reagents (Roche, Indianapolis, IN, USA). Primers (ZIKV-835 5'-TTG GTC ATG ATA CTG CTG ATT GC-3' and ZIKV-911c $5^{\prime}$-CCT TCC ACA AAG TCC CTA TTG C-3') specific for ZIKV were synthesized by IDT Inc. (San Jose, CA, USA) and were previously described ${ }^{55}$. The amplification was done by: initiation $95^{\circ} \mathrm{C}$ for 10 minutes followed by 50 amplification cycles of $95^{\circ} \mathrm{C}$ for 15 seconds, $60^{\circ} \mathrm{C}$ for 30 seconds, and $72^{\circ} \mathrm{C}$ for 30 seconds.

ZIKV RNA from fetuses' heads were detected using TaqMan ${ }^{\circledR}$ Universal Master Mix II, no UNG (Thermofisher). The primers used are: ZIKV835: TTG GTC ATG ATA CTG CTG ATT GC; ZIKV911c: CCT TCC ACA AAG TCC CTA TTG C and the probe ZIKV860FAM: CGG CAT ACA GCA TCA GGT GCA TAG GAG. The samples were carried out in $20 \mu \mathrm{l}$ reactions and the run method was as follows: 10 minutes at $95^{\circ} \mathrm{C}$, 42 cycles of 15 seconds at $95^{\circ} \mathrm{C}$ followed by 1 minute at $58^{\circ} \mathrm{C}$. The sensitivity of the ZIKV real-time assays was evaluated by titration of serial dilution of virus with previously known titer. Samples with $\mathrm{C}_{t}$ values above 40 were 
excluded from the analysis and represented as non-detected samples (n.d.). GraphPad Prism was used as fitting software.

Human antiviral response qPCR array analysis in NPCs. $500 \mathrm{ng}$ of total RNA from mock, ZIKV (strain ibH 30656)-infected at an MOI of 0.1 and ZIKV-infected treated with 50 $\mu \mathrm{M}$ SOF NPCs were extracted at 120 hours p.i. and submitted to gene expression analysis Human antiviral response genes using the RT2 Profiler PCR Array (cat. no. PAHS-122ZD - Qiagen) according to the manufacturer's protocols. qPCR was on a CFX96 Touch Real-Time PCR Detection System (Bio-rad). To evaluate gene expression, we established a twofold up- or downregulation compared to mock infected samples. Data was analyzed using the RT ${ }^{2}$ profiler RT-PCR array data analysis software v3.5.

Viral culture and amplification. The ZIKV strain ibH 30656, isolated from human blood in Nigeria, the strain (PA 259459), isolated from human blood in Panama and Brazil-ZKV2015 isolated from a febrile case in the state of Paraiba (Brazil) were amplified using the African green monkey kidney cells (Vero) and titers determined by plaque assay as previously reported ${ }^{21}$. Both strains of ZIKV isolated from Nigeria and Panama were obtained from the World Reference Center for Emerging Viruses and Arboviruses at the University of Texas Medical Branch, Galveston. Vero cells were cultured in DMEM supplemented with $10 \%$ fetal bovine serum (FBS; HyClone, Logan, Utah) and $1 \%$ penicillin/streptomycin (P/S). The cells were maintained at $37^{\circ} \mathrm{C}$ and $5 \%$ of $\mathrm{CO}_{2}$.

Plaque forming assay. Monolayers of Vero cells plated on 48-well plates were exposed to different dilutions of the supernatant from yield-reduction assays for 1 hour at $37^{\circ} \mathrm{C}$. Next, cells were washed with PBS and DMEM containing $1 \%$ FBS and $0.4 \%$ Agarose (Ultrapure Life technologies) (overlay medium) was added to cells. After 7 days at $37^{\circ} \mathrm{C}$, the monolayers were fixed with $4 \%$ of paraformaldehyde in PBS and stained with a $0.1 \%$ solution of crystal violet in $70 \%$ methanol. The virus titers were calculated by scoring the plaque forming units (PFU) using the following formula: number of plaques/(dilution factor $\times$ volume).

Human stem cell culture. For the generation of NPCs, cells were differentiated and maintained as previously described $^{56-58}$. Two control iPSC lines maintained in mTeSR media were switched to N2 [DMEM/F12 media supplemented with 1x N2 NeuroPlex Serum-Free Supplement (Gemini) with the dual SMAD inhibitors $1 \mu \mathrm{M}$ of dorsomorphin (Tocris) and $10 \mu \mathrm{M}$ of SB431542 (Stemgent)] daily, for 48 hours. After two days, colonies were scraped off and cultured under agitation $(95 \mathrm{rpm})$ as embryoid bodies for seven days using N2 media with dorsomorphin and SB431542. Media was changed every other day. Embryoid bodies were then plated on Matrigel-coated dishes, and maintained in DMEM/F1 2 supplemented with $0.5 \times$ of N2 supplement, $0.5 \times$ Gem 21 NeuroPlex Serum-Free Supplement (Gemini), $20 \mathrm{ng} / \mathrm{mL}$ basic fibroblast growth factor (bFGF, LifeTechnologies) and $1 \%$ penicillin/streptomycin (P/S). After 7 days in culture, formed rosettes from the plated EBs were manually selected, gently dissociated with StemPro Accutase (LifeTechnologies) and plated onto $10 \mu \mathrm{g} / \mathrm{mL}$ poly-L-ornithine (Sigma) $/ 5 \mu \mathrm{g} / \mathrm{mL}$ laminin (LifeTechnologies) coated plates. Neuronal progenitor cells (NPCs) were maintained in DMEM/F12 with N2, Gem21, bFGF and P/S. To induce cortical neuron differentiation, FGF was retrieved as previously described ${ }^{57}$. The cortical neurons were allowed to differentiate for 4 weeks before infection with ZIKV. The media was changed every other day. NPCs were expanded as soon as confluent, using StemPro Accutase for 5 minutes at $37^{\circ} \mathrm{C}$, centrifuged and replated with NGF with a 1:3 ratio in poly-L-ornithine/Laminin-coated plates. All the cell lines tested negative for mycoplasma contamination. All experiments were approved and performed in accordance with the Institutional Review Boards (IRB) and Embryonic Stem Cell Research Oversight (ESCRO) guidelines and regulations.

In vitro infection. NPCs and neurons were infected with the ibH 30656 or Brazil-ZKV2015 strain of ZIKV as described before ${ }^{21}$. The viruses were used at MOIs of 0.1 and 1 for TUNEL assays and MOI of 0.1 or 10 for the neurosphere assays. For mock controls, the same volume of supernatant from Vero cells was added to each experiment. For the vehicle of SOF treatment, equivalent volume of DMSO corresponding to the highest SOF dose was added into the culture media ( $0.1 \%$ of DMSO). For neuronal infection, NPCs were previously differentiated for 28 days and then neurons were infected at an MOI $=10$. NPCs and neurons were treated immediately after infection and every 24 hours for the duration of the experiment. SOF (Acme Bioscience AB3793) was added to cell culture supernatant at the desired concentration.

Neurosphere assay. NPCs were plated and infected as described above. After the infection, fresh media containing different concentrations of SOF $(10$ and $20 \mu \mathrm{M})$ or vehicle $(0.1 \%$ DMSO $)$ was added. The next day, cells were lifted and cultured under gentle agitation $(95 \mathrm{rpm})$ as neurospheres for 24 hours. At 48, 72, 120 and 180 hours p.i., images of neurospheres were captured using EVOS Cell Imaging System (ThermoFisher) and analyzed with ImageJ software. We measured the neurospheres size and viability over time, in the absence of media change to avoid any viral load decrease in the media. The size of neurospheres was measured as the area (number of pixels) calculated using ImageJ software.

Histology and immunohistochemistry. Mouse embryo at E18.5 were fixed for 48 hours in $4 \%$ formaldehyde in PBS, transferred to sucrose, and embedded in paraffin. Then serial sections of $5 \mu \mathrm{m}$ were prepared, cutting along the sagittal axis of the embryo. Slides were deparaffinized and rehydrated through a series of xylenes and graded ethanol. Antigen retrieval was performed in a pressure cooker at 7.5 psi placing the slides in $0.1 \mathrm{M}$ Tris- $\mathrm{HCl}$ buffer ( $\mathrm{pH}$ 9) for 15 minutes. Slides were rinsed in room temperature distilled water for 6 times, followed by 5 minutes washing in PBS. Endogenous peroxidase activity was then quenched by incubation with $3 \%$ hydrogen peroxide in PBS for 30 minutes at room temperature. Slides were in PBS for 5 minutes washed and incubated over-night at $4{ }^{\circ} \mathrm{C}$ with the primary antibody (Flavivirus Group Antigen, Millipore, \#MAB10216) 
diluted 1:250 in Dako Antibody Diluent with Background Reducing Components (Agilent, \#S3022). Slides were rinse in PBS three times for 5 minutes and then incubated with the secondary antibody polymer HRP conjugated (Abcam, \#ab2891, goat anti mouse) for 30 minutes at room temperature, followed by three times washing in PBS and a 3-minute incubation with the DAB complex, prepared as directed by manufacturer (ImmPACT DAB Peroxidase Substrate, Vector Laboratories, \#SK-4105). Slides were washed three times in PBS and three times in water, before being counterstained in Mayer's hematoxylin, dehydrated with a series of graded ethanol and xylenes and finally mounted. Sections were scanned and acquired using Aperio automated system (Leica) and analyzed with ImageScope (Leica).

Immunofluorescence and imaging analyses. Cells were fixed with $4 \%$ paraformaldehyde for 20 minutes at room temperature. Next, samples were permeabilized in $1 \times$-PBS containing $0.1 \%(\mathrm{v} / \mathrm{v})$ Triton X-100 for 10 minutes. Fixed cells were next incubated with blocking solution [ $1 \%$ fetal bovine serum, (Life Technologies) in $1 x P B S]$. After 1 hour, the primary antibodies directed against the following were added: Anti-Flavivirus D1-4G2-4-15 (polyclonal mouse, Millipore, 1:250), cleaved caspase-3 (rabbit, Cell Signaling \#9661, 1:400), Nestin (rabbit, Abcam ab105389, 1:500) were added (diluted in blocking solution) and samples were incubated overnight at $4{ }^{\circ} \mathrm{C}$. Slides were then washed two times with $1 \mathrm{x}$-PBS, and incubated with the secondary antibody for 30 minutes at $4^{\circ} \mathrm{C}$. Secondary antibodies (all conjugated to Alexa Fluor 488, 555 and 647) were purchased from Life Technologies and used at a 1:1000 dilution. After the 30 minutes incubation, samples were washed twice $(1 \times-P B S)$, incubated for 5 minutes with and fluorescent nuclear DAPI stain, and mounted with Slow fade gold antifade reagent (Life Technologies). Samples were imaged using an Axio Observer Z1 Microscope with ApoTome (Zeiss). Captured images were analyzed with Zen software from Zeiss. For TUNEL analysis, NPCs were plated, infected after 24 hours, and fixed 96 hours p.i. with $4 \%$ paraformaldehyde for 20 minutes. Samples were permeabilized with $0.25 \%$ Triton X-100 for 15 minutes and then stained for TUNEL (Click-iT TUNEL assay kit from Life Technologies). Cells were then blocked with $10 \%$ fetal bovine serum for 60 minutes and then incubated in primary antibodies (anti-Nestin antibodies purchased from Abcam and anti-flavivirus antibodies purchased from Millipore) overnight at $4^{\circ} \mathrm{C}$ and stained with secondary antibodies and DAPI (Life Technologies, 1:5000) diluted in a phosphate buffer saline (PBS) $1 \mathrm{x}$ solution for 5 minutes the following day prior to mounting (Life Technologies, ProLong Gold). Images were blindly collected using an Axio Observer Z1 Microscope with ApoTome (Zeiss) and blindly analyzed with ImageJ software.

Yield-reduction assay. Vero cells were seeded in 384-well plate and $~ 90 \%$ confluence (4000 cells/well) in $50 \mu \mathrm{l}$ of media (DMEM with 10\% FBS) and NPCs were plated at a density of 10,000 cells/well in 384 well plate. A serial dilution was prepared in stock plate starting at $10 \mathrm{mM}$ with 2 -fold dilution and 10 dilution points. 250 $\mathrm{nL}$ of compound using an Acoustic Transfer System (EDC Biosystems) were transferred from stock plate in triplicate for each concentration. After adding the compound, the plate was incubated for 10 minutes before infection. NPCs were then infected with ZIKV at an MOI of 1 and Vero cells at an MOI of 5 (ibH 30656) and completed the volume of the wells to $50 \mu$ with DMEM/F12 supplemented with $0.5 \times$ of N2 supplement, $0.5 \times$ Gem 21 NeuroPlex Serum-Free Supplement (Gemini), $20 \mathrm{ng} / \mathrm{mL}$ basic fibroblast growth factor (bFGF, LifeTechnologies) and $1 \%$ penicillin/streptomycin $(\mathrm{P} / \mathrm{S})$. After 96 hours of incubation the plates were fixed with $4 \%$ formaldehyde and stained with $5 \mu \mathrm{g} / \mathrm{ml}$ of DAPI for 1 hour. The plate was read in the Perkin Elmer ImageXpress Micro XL automated microscope and analyzed by a custom MetaXpress software algorithm able to identify and quantify apoptotic nuclei. The software calculated the number of apoptotic nuclei and the total number of nuclei per well. The apoptotic ratio was calculated dividing the number of apoptotic cells by the total number of cells (percentage of apoptosis). The normalized antiviral activity was calculated based on the average apoptosis in the positive control group (not infected wells, $100 \%$ antiviral activity) and the average apoptosis in the negative control group (infected and not treated, $0 \%$ antiviral efficacy). The dose-response curve was calculated using GraphPad software with the nonlinear regression curve fit, dose-response inhibition with variable slope (four parameters). For Vero cells, after 6 days of incubation, $5 \mu \mathrm{l}$ of Resazurin $0.2 \mathrm{mg} / \mathrm{ml}$ was added (Santa Cruz Biotecnology, sc-206037), incubated for 1 hour at $37^{\circ} \mathrm{C}$ and then the plate was read (excitation/emission -560/590) with EnVision 2104 MultiLabel Reader (PerkinElmer). The IC50 was calculated using Prism GraphPad: non-linear curve fitting with variable slope (four parameters) with the following model:

$$
\mathrm{Y}=\text { Bottom }+(\text { Top }- \text { Bottom }) /\left(1+10^{\wedge}((\operatorname{LogEC} 50-\mathrm{X}) * \text { HillSlope }\right.
$$

Sofosbuvir and GS-331007 analysis. GS-331007 was purchased from Cayman Chemical. Extraction and analysis of GS-331007 was performed using a modified protocol of a previously reported method ${ }^{59}$. Extractions were performed by adding $300 \mu \mathrm{l}$ of ethyl acetate to $50 \mu \mathrm{l}$ of serum $(6: 1 \mathrm{v} / \mathrm{v})$. Samples were then vortexed for 60 seconds followed by centrifugation at $2200 \times g$ for 5 minutes. The organic layer (top) was collected and dried under a stream of nitrogen. The extract was then dissolved in $50 \mu \mathrm{l}$ of $1: 1 \mathrm{ACN}: \mathrm{H}_{2} 0$ and $10 \mu \mathrm{l}$ was analyzed by liquid chromatography mass spectrometry (LCMS) using a Thermo TSQ Quantiva instrument. LC separation was achieved using a Gemini 5U C18 column (Phenomenex). SOF and GS-331007 was resolved via isocratic flow at $0.4 \mathrm{ml} /$ minute for 5 minutes using $50: 50 \mathrm{ACN}: \mathrm{H}_{2} \mathrm{O}$ with $0.1 \%$ formic acid as solvent. MS analyses were performed using electrospray ionization (ESI) in positive ion mode with the following source parameters: spray voltage of $3.5 \mathrm{kV}$, ion transfer tube temperature of $325^{\circ} \mathrm{C}$, and vaporizer temperature of $275^{\circ} \mathrm{C}$. MRM was used to detect $\mathrm{SOF}(\mathrm{m} / \mathrm{z} 530.2 \rightarrow 243, \mathrm{CE}=20 \mathrm{~V})$ and GS-331007 $(\mathrm{m} / \mathrm{z} 261.1 \rightarrow 113, \mathrm{CE}=13 \mathrm{~V})$. Concentrations of SOF and GS-331007 in serum samples were calculated by referring to a prepared calibration curve.

ZIKV and HCV representative elements selection. According to a recently updated nomenclature, $\mathrm{HCV}$ is classified into 7 genotypes, which are subdivided into 67 epidemiologically diverse subtypes ${ }^{60,61}$. To create 
the phylogenetic tree, we selected representative elements from ZIKV and HCV. HCV is subdivided in 7 genotypes, the following representative virus were used for phylogenetic analysis: genotype 1-M62321, M67463; genotype 2-D00944, AB047639; genotype 3-D17763, D28917; genotype 4-Y11604, FJ462435; genotype 5-Y13184, AF064490; genotype 6-Y12083, AY859526; genotype 7-EF108306. We also selected a set of representative strains from ZIKV, corresponding to the Asian and the African virus lineages ${ }^{62}$. On total, seven representatives from African lineages (accession numbers: KF268948, KF268950, KF268949, LC002520, AY632535, HQ234500, HQ234501) and five representatives from Asian lineages (accession numbers: KJ776791, KF993678, JN860885, EU545988, HQ234499).

ZIKV NS5 structural modeling. Residues 396-731 of ZIKV polymerase NS5 (unpublished; PDB ID 5TFR) were structurally aligned with residues 84-386 of HCV NS5 (PDB ID 4WTG; 12) in PyMOL. The rotamer for ZIKV NS5 residue D540 was manually adjusted to match that of HCV; the difference likely arose due to the lack of substrate in the ZIKV NS5 structure. Structures overlays and movies were generated in PyMOL.

Virus amino acid sequences. Virus amino acid sequences corresponding to the RNA polymerase from both flaviviruses (NS5 protein) and hepacivirus (NS5b protein) were downloaded from ViPR web resource ${ }^{63}$ (URL: https://www.viprbrc.org/), and based on completed sequenced molecules. The downloaded flaviviruses sequences and corresponding accessions are: West Nile Virus (genbank: KC601756 ${ }^{64}$ ), Japanese Encephalitis (genbank: JX131374 ${ }^{65}$ ), Dengue Fever (genbank: NC_002640 ${ }^{66}$ ) and ZIKV (genbank: KU497555 ${ }^{67}$ ). The downloaded Hepacivirus amino acid sequence and corresponding accession is: Hepatitis C Virus (genbank: EF424625 ${ }^{68}$ ). As the RNA polymerase (RNApol) from both flaviviruses and hepaciviruses are contained within NS5 protein and NS5b protein respectively, we extracted only the RNApol amino acid sequences for subsequent analysis.

Phylogenetic tree construction of RNA polymerase. Amino acid sequences corresponding to RNA polymerase from both Flavivirus and Hepacivirus were subjected to phylogenetic tree analysis using the online software resource Phylogeny. $\mathrm{fr}^{69}$. The software is based on a built-in pipeline with chaining programs with recognized accuracy as follow: MUSCLE for multiple alignment ${ }^{70}$, Gblocks for alignment refinement ${ }^{71}$, PhyML for tree building ${ }^{72}$, and TreeDyn for tree rendering ${ }^{73}$. All parameters are set up to default, as they are suitable for the investigated virus ${ }^{69}$.

RNA polymerase amino acid sequence conservation analysis. Amino acid sequences corresponding to RNA polymerase from both Flavivirus and Hepacivirus were subjected to multiple amino acid sequence alignment for DPP domain detection and sequence conservation using Clustall OWS software available through Jalview 2.9.0 $0^{74}$. After final sequence alignment, DPP triamino acid sequence was located using textual search.

Statistical analysis. One-way ANOVA tests followed by a Tukey multiple comparison test were used to compare groups and Student's t-test to compare means of two groups. For statistical analysis of data containing two variables (time and treatment), two-way ANOVA tests followed by a Tukey multiple comparison test was used. Kaplan-Meier Log Rank test was used for survival curves.

\section{References}

1. Campos, G. S., Bandeira, A. C. \& Sardi, S. I. Zika virus outbreak, Bahia, Brazil. Emerg. Infect. Dis. 21, 1885-1886 (2015).

2. Mlakar, J. et al. Zika Virus Associated with Microcephaly. N. Engl. J. Med. 374, 951-8 (2016).

3. van der Linden, V. et al. Description of 13 Infants Born During October 2015-January 2016 With Congenital Zika Virus Infection Without Microcephaly at Birth - Brazil. MMWR. Morb. Mortal. Wkly. Rep. 65, 1343-1348 (2016).

4. Xu, M. et al. Identification of small-molecule inhibitors of Zika virus infection and induced neural cell death via a drug repurposing screen. Nat. Med. 22, 1101-1107 (2016).

5. Retallack, H. et al. Zika virus cell tropism in the developing human brain and inhibition by azithromycin. Proc. Natl. Acad. Sci. USA 113, 201618029 (2016).

6. Barrows, N. J. et al. A Screen of FDA-Approved Drugs for Inhibitors of Zika Virus Infection. Cell Host Microbe 20, 259-270 (2016).

7. Abbink, P. et al. Protective efficacy of multiple vaccine platforms against Zika virus challenge in rhesus monkeys. Science (2016). doi:10.1126/science.aah6157

8. Larocca, R. A. et al. Vaccine protection against Zika virus from Brazil. Nature, https://doi.org/10.1038/nature18952 (2016).

9. Reefhuis, J. et al. Projecting Month of Birth for At-Risk Infants after Zika Virus Disease Outbreaks. Emerg. Infect. Dis. 22, 828-32 (2016).

10. Sacramento, C. Q. et al. The clinically approved antiviral drug sofosbuvir inhibits Zika virus replication. Sci. Rep. 7, 40920 (2017).

11. Onorati, M. et al. Zika Virus Disrupts Phospho-TBK1 Localization and Mitosis in Human Neuroepithelial Stem Cells and Radial Glia. Cell Rep. 16, 2576-2592 (2016).

12. Bullard-Feibelman, K. M. et al. The FDA-approved drug sofosbuvir inhibits Zika virus infection. Antiviral Res. 137, 134-140 (2017).

13. Ferreira, A. C. et al. Sofosbuvir protects Zika virus-infected mice from mortality, preventing short- and long-term sequelae. Sci. Rep. 7, 9409 (2017).

14. Sulkowski, M. S. et al. Daclatasvir plus sofosbuvir for previously treated or untreated chronic HCV infection. N. Engl. J. Med. 370, 211-21 (2014).

15. Gentile, I., Maraolo, A. E., Buonomo, A. R., Zappulo, E. \& Borgia, G. The discovery of sofosbuvir: a revolution for therapy of chronic hepatitis C. Expert Opin. Drug Discov. 10, 1363-77 (2015).

16. Toussaint-Miller, K. A. \& Andres, J. Treatment Considerations for Unique Patient Populations With HCV Genotype 1 Infection. Ann. Pharmacother. 49, 1015-30 (2015).

17. Elfiky, A. A., Elshemey, W. M., Gawad, W. A. \& Desoky, O. S. Molecular modeling comparison of the performance of NS5b polymerase inhibitor (PSI-7977) on prevalent HCV genotypes. Protein J. 32, 75-80 (2013).

18. Xu, D. et al. Fialuridine induces acute liver failure in chimeric TK-NOG mice: a model for detecting hepatic drug toxicity prior to human testing. PLoS Med. 11, e1001628 (2014).

19. Li, C. et al. Zika Virus Disrupts Neural Progenitor Development and Leads to Microcephaly in Mice. Cell Stem Cell 19, 1-7 (2016).

20. Souza, B. S. F. et al. Zika virus infection induces mitosis abnormalities and apoptotic cell death of human neural progenitor cells. Sci. Rep. 6, 39775 (2016). 
21. Cugola, F. R. et al. The Brazilian Zika virus strain causes birth defects in experimental models. Nature 1-15, https://doi.org/10.1038/ nature18296 (2016)

22. Lindenbach, B. D. \& Rice, C. M. In Fields virology, 5th Edition (2007).

23. Appleby, T. C. et al. Viral replication. Structural basis for RNA replication by the hepatitis C virus polymerase. Science 347, 771-5 (2015).

24. Garcez, P. P. et al. Zika virus impairs growth in human neurospheres and brain organoids. Science aaf6116 https://doi.org/10.1126/ science.aaf6116 (2016).

25. Dang, J. et al. Zika Virus Depletes Neural Progenitors in Human Cerebral Organoids through Activation of the Innate Immune Receptor TLR3. Cell Stem Cell, 1-8, https://doi.org/10.1016/j.stem.2016.04.014 (2016).

26. Tang, H. et al. Zika Virus Infects Human Cortical Neural Progenitors and Attenuates Their Growth. Cell Stem Cell 18, 587-590 (2016).

27. Wu, K.-Y. et al. Vertical transmission of Zika virus targeting the radial glial cells affects cortex development of offspring mice. Cell Res., https://doi.org/10.1038/cr.2016.58 (2016).

28. Reznik, S. E. \& Ashby, J. C. R. Sofosbuvir: an anti-viral drug with potential efficacy against Zika infection. Int. J. Infect. Dis. 55, In press (2016).

29. Mesci, P. et al. Modeling neuro-immune interactions during Zika virus infection. Hum. Mol. Genet. https://doi.org/10.1093/hmg/ ddx382 (2017).

30. Zmurko, J. et al. Substrate selectivity of Dengue and Zika virus NS5 polymerase towards 2'-modified nucleotide analogues. Antiviral Res. 55, In press (2016)

31. Kataoka, S. et al. Immunologic aspects of the nonobese diabetic (NOD) mouse. Abnormalities of cellular immunity. Diabetes 32, 247-53 (1983).

32. Zmurko, J. et al. The Viral Polymerase Inhibitor 7-Deaza-2'-C-Methyladenosine Is a Potent Inhibitor of In Vitro Zika Virus Replication and Delays Disease Progression in a Robust Mouse Infection Model. PLoS Negl. Trop. Dis. 10, e0004695-e0004695 (2016).

33. Lazear, H. M. et al. A Mouse Model of Zika Virus Pathogenesis Cell Host \&amp; Microbe Resource A Mouse Model of Zika Virus Pathogenesis. Cell Host Microbe 19, 1-11 (2016).

34. Rossi, S. L. et al. Characterization of a Novel Murine Model to Study Zika Virus. Am. J. Trop. Med. Hyg. 94, ajtmh.16-0111 (2016).

35. Aliota, M. T. et al. Characterization of Lethal Zika Virus Infection in AG129 Mice. PLoS Negl. Trop. Dis. 10, e0004682 (2016).

36. Nair, A. B. \& Jacob, S. A simple practice guide for dose conversion between animals and human. J. basic Clin. Pharm. 7, 27-31 (2016).

37. Gilead Sciences, I. Highlights of prescribing information. United States Food \& Drug Administration Available at: https://www. accessdata.fda.gov/drugsatfda_docs/label/2013/204671s000lbl.pdf (2013).

38. Shiryaev, S. A. et al. Repurposing of the anti-malaria drug chloroquine for Zika Virus treatment and prophylaxis. Sci. Rep. 7, 15771 (2017).

39. Styer, L. M. et al. Mosquitoes inoculate high doses of West Nile virus as they probe and feed on live hosts. PLoS Pathog. 3, 1262-1270 (2007).

40. Barrows, N. J. et al. A Screen of FDA-Approved Drugs for Inhibitors of Zika Virus Infection. Cell Host Microbe 20, 259-70 (2016).

41. Oliveira, D. B. L. et al. Prolonged Shedding of Zika Virus Associated with Congenital Infection. N. Engl. J. Med. 375, 1202-1204 (2016).

42. Ginhoux, F. et al. Fate mapping analysis reveals that adult microglia derive from primitive macrophages. Science 330, 841-5 (2010).

43. Mandelbrot, L. et al. No perinatal HIV-1 transmission from women with effective antiretroviral therapy starting before conception. Clin. Infect. Dis. 61, 1715-25 (2015).

44. Pasternak, B. \& Hviid, A. Use of acyclovir, valacyclovir, and famciclovir in the first trimester of pregnancy and the risk of birth defects. JAMA 304, 859-66 (2010)

45. Ellis, C. Center for drug evaluation and research 204671Orig1s000. Pharmacology Review(S) (2013).

46. Nishiura, H. et al. A theoretical estimate of the risk of microcephaly during pregnancy with Zika virus infection. Epidemics 15, 66-70 (2016).

47. Bhatia, H. K., Singh, H., Grewal, N. \& Natt, N. K. Sofosbuvir: A novel treatment option for chronic hepatitis Cinfection. J. Pharmacol. Pharmacother. 5, 278-284 (2014).

48. Broutet, N. et al. Zika Virus as a Cause of Neurologic Disorders. N. Engl. J. Med. 374, 1506-9 (2016)

49. Carteaux, G. et al. Zika Virus Associated with Meningoencephalitis. N. Engl. J. Med. 374, 1595-6 (2016)

50. Furtado, J. M., Espósito, D. L., Klein, T. M., Teixeira-Pinto, T. \& da Fonseca, B. A. Uveitis Associated with Zika Virus Infection. N. Engl. J. Med. 375, 394-6 (2016).

51. Mécharles, S. et al. Acute myelitis due to Zika virus infection. Lancet (London, England) 387, 1481 (2016).

52. Eyer, L. et al. Nucleoside inhibitors of Zika virus. J. Infect. Dis. (2016). doi:10.1093/infdis/jiw226

53. Potisopon, S., Ferron, F., Fattorini, V. \& Selisko, B. \& Canard, B. Substrate selectivity of Dengue and Zika virus NS5 polymerase towards 2'-modified nucleotide analogues. Antiviral Res. 140, 25-36 (2016)

54. Balm, M. N. D. et al. A diagnostic polymerase chain reaction assay for Zika virus. J. Med. Virol. 84, 1501-5 (2012).

55. Lanciotti, R. S. et al. Genetic and serologic properties of Zika virus associated with an epidemic, Yap State, Micronesia, 2007. Emerg. Infect. Dis. 14, 1232-1239 (2008).

56. Chailangkarn, T. et al. A human neurodevelopmental model for Williams syndrome. Nature, https://doi.org/10.1038/nature19067 (2016).

57. Marchetto, M. C. N. et al. A model for neural development and treatment of Rett syndrome using human induced pluripotent stem cells. Cell 143, 527-39 (2010).

58. Marchetto, M. C. et al. Altered proliferation and networks in neural cells derived from idiopathic autistic individuals. Mol. Psychiatry, https://doi.org/10.1038/mp.2016.95 (2016).

59. Rezk, M. R., Basalious, E. B. \& Karim, I. A. Development of a sensitive UPLC-ESI-MS/MS method for quantification of sofosbuvir and its metabolite, GS-331007, in human plasma: Application to a bioequivalence study. J. Pharm. Biomed. Anal. 114, 97-104 (2015).

60. Jackowiak, P. et al. Phylogeny and molecular evolution of the hepatitis C virus. Infect. Genet. Evol. 21, 67-82 (2014).

61. Smith, D. B. et al. Expanded classification of hepatitis $C$ virus into 7 genotypes and 67 subtypes: updated criteria and genotype assignment web resource. Hepatology 59, 318-27 (2014).

62. Enfissi, A., Codrington, J., Roosblad, J., Kazanji, M. \& Rousset, D. Zika virus genome from the Americas. Lancet (London, England) 387, 227-8 (2016).

63. Pickett, B. E. et al. ViPR: an open bioinformatics database and analysis resource for virology research. Nucleic Acids Res. 40, D593-8 (2012).

64. Balakrishnan, A., Butte, D. K. \& Jadhav, S. M. Complete Genome Sequence of West Nile Virus Isolated from Alappuzha District, Kerala, India. Genome Announc. 1, 4-5 (2013).

65. Singha, H. et al. Complete genome sequence analysis of Japanese encephalitis virus isolated from a horse in India. Arch. Virol. 158, $113-122(2013)$ 
66. Naveca, F. G. et al. Complete Genome Sequence of a Dengue Virus Serotype 4 Strain Isolated in Roraima, Brazil. J. Virol. 86, 1897-1898 (2012).

67. Calvet, G. et al. Case Report of detection of Zika virus genome in amniotic fluid of affected fetuses: association with microcephaly outbreak in Brazil. Lancet Infect. Dis. 3099, In press (2016).

68. Lu, L. et al. Complete genomes of hepatitis C virus (HCV) subtypes $6 c, 61,60,6 \mathrm{p}$ and $6 \mathrm{q}$ : completion of a full panel of genomes for HCV genotype 6. J. Gen. Virol. 88, 1519-1525 (2007).

69. Dereeper, A. et al. Phylogeny.fr: robust phylogenetic analysis for the non-specialist. Nucleic Acids Res. 36, W465-9 (2008).

70. Edgar, R. C. MUSCLE: multiple sequence alignment with high accuracy and high throughput. Nucleic Acids Res. 32, 1792-7 (2004).

71. Castresana, J. Selection of Conserved Blocks from Multiple Alignments for Their Use in Phylogenetic Analysis. Mol. Biol. Evol 17, $540-552(2000)$.

72. Guindon, S. \& Gascuel, O. A simple, fast, and accurate algorithm to estimate large phylogenies by maximum likelihood. Syst. Biol. 52, 696-704 (2003).

73. Chevenet, F., Brun, C., Bañuls, A.-L., Jacq, B. \& Christen, R. TreeDyn: towards dynamic graphics and annotations for analyses of trees. BMC Bioinformatics 7, 439 (2006)

74. Waterhouse, A. M., Procter, J. B., Martin, D. M. A., Clamp, M. \& Barton, G. J. Jalview Version 2-a multiple sequence alignment editor and analysis workbench. Bioinformatics 25, 1189-1191 (2009).

\section{Acknowledgements}

This work was supported by grants from the California Institute for Regenerative Medicine (DISC2-09649), the National Institutes of Health through the U19MH107367, the NGO “The tooth fairy project", and an NARSAD Independent Investigator Grant to A.R.M. M.J.K. is funded by F30 DK112604 grant. Dr. Mesci has an International Rett syndrome foundation (IRSF) mentored training fellowship. Dr. Macia has an NARSAD Young Investigator Grant and Spencer M. Moore is supported by a grant from the Autism Science Foundation and Rett Syndrome Research Trust (RSRT). K.D.C. acknowledges support from the Ludwig Institute for Cancer Research. We thank Mary Braxtan, Buddy Charbono, Francisco Beltran, Hilda Clarke and the SBP Animal Facility Core for their help with animal experiments. We also like to thank E. Durigon and his group for the ZKV2015 aliquots, and P. Vasconcelos for providing a lyophilized ZKV2015 seed. Dr. Mesci and Dr. Macia drew the mouse schematics in the manuscript.

\section{Author Contributions}

P.M., A.M., S.M.M. and A.R.M. contributed to the concept and designed the study. P.M., A.M., S.M.M. performed and analyzed all the experiments with the help from L.T., I.R.F., N.A.S., J.L.S.N., K.D.C., R.H.H., M.J.K. and A.S. performed LCMS experiments; J.D.M. helped analyzing the LCMS experiments and provided with pharmacological insight. S.A.S., A.P., C.-T.H. and A.V.T. performed the SJL mice experiments, S.M. and J.L.S.-N. performed the IC50 experiments, S.C.R. and K.D.C. did the 3D modeling. F.R.C., F.B.R. and P.C.B.B.B. performed the in vitro NPC and neuronal toxicity experiments with the ZIKV 2015. S.S. and N.S. helped designing in vivo SOF experiments and P.M. wrote the manuscript with the input from A.M., S.M.M. and A.R.M.

\section{Additional Information}

Supplementary information accompanies this paper at https://doi.org/10.1038/s41598-018-19526-4.

Competing Interests: The authors declare that they have no competing interests.

Publisher's note: Springer Nature remains neutral with regard to jurisdictional claims in published maps and institutional affiliations.

(c) (i) Open Access This article is licensed under a Creative Commons Attribution 4.0 International

License, which permits use, sharing, adaptation, distribution and reproduction in any medium or format, as long as you give appropriate credit to the original author(s) and the source, provide a link to the Creative Commons license, and indicate if changes were made. The images or other third party material in this article are included in the article's Creative Commons license, unless indicated otherwise in a credit line to the material. If material is not included in the article's Creative Commons license and your intended use is not permitted by statutory regulation or exceeds the permitted use, you will need to obtain permission directly from the copyright holder. To view a copy of this license, visit http://creativecommons.org/licenses/by/4.0/.

(C) The Author(s) 2018 


\title{
NS1 codon usage adaptation to humans in pandemic Zika virus
}

\author{
Caio César de Melo Freire', Giuseppe Palmisano², Carla T Braconi ${ }^{3}$, \\ Fernanda R Cugola ${ }^{4}$, Fabiele B Russo ${ }^{4}$, Patricia CB Beltrão-Braga ${ }^{4,5}$, Atila lamarino ${ }^{3}$, \\ Daniel Ferreira de Lima Neto ${ }^{3}$, Amadou Alpha Sall ${ }^{6}$, Livia Rosa-Fernandes ${ }^{7}$, \\ Martin R Larsen 7 , Paolo Marinho de Andrade Zanotto ${ }^{3 /+}$
}

${ }^{1}$ Universidade Federal de São Carlos, Departamento de Genética e Evolução, São Carlos, SP, Brasil

${ }^{2}$ Universidade de São Paulo, Instituto de Ciências Biomédicas, Departamento de Parasitologia, São Paulo, SP, Brasil

${ }^{3}$ Universidade de São Paulo, Instituto de Ciências Biomédicas, Departamento de Microbiologia, Laboratório de Evolução Molecular e

Bioinformática, São Paulo, SP, Brasil

${ }^{4}$ Universidade de São Paulo, Laboratório de Células-Tronco, Departamento de Cirurgia, São Paulo, SP, Brasil

${ }^{5}$ Universidade de São Paulo, Escola de Artes, Ciências e Humanidades, Departamento de Obstetrícia, São Paulo, SP, Brasil

${ }^{6}$ Institute Pasteur of Dakar, Dakar, Senegal

${ }^{7}$ University of Southern Denmark, Department of Biochemistry and Molecular Biology, Odense, Denmark

BACKGROUND Zika virus (ZIKV) was recognised as a zoonotic pathogen in Africa and southeastern Asia. Human infections were infrequently reported until 2007, when the first known epidemic occurred in Micronesia. After 2013, the Asian lineage of ZIKV spread along the Pacific Islands and Americas, causing severe outbreaks with millions of human infections. The recent human infections of ZIKV were also associated with severe complications, such as an increase in cases of Guillain-Barre syndrome and the emergence of congenital Zika syndrome.

OBJECTIVES To better understand the recent and rapid expansion of ZIKV, as well as the presentation of novel complications, we compared the genetic differences between the African sylvatic lineage and the Asian epidemic lineage that caused the recent massive outbreaks.

FINDINGS The epidemic lineages have significant codon adaptation in NS1 gene to translate these proteins in human and Aedes aegypti mosquito cells compared to the African zoonotic lineage. Accordingly, a Brazilian epidemic isolate $\left(Z^{\mathrm{BR}}\right)$ produced more NS1 protein than the MR766 African lineage $\left(Z^{\mathrm{AF}}\right)$ did, as indicated by proteomic data from infections of neuron progenitor cellsderived neurospheres. Although $Z^{\mathrm{BR}}$ replicated more efficiently in these cells, the differences observed in the stoichiometry of ZIKV proteins were not exclusively explained by the differences in viral replication between the lineages.

MAIN CONCLUSIONS Our findings suggest that natural, silent translational selection in the second half of 20th century could have improved the fitness of Asian ZIKV lineage in human and mosquito cells.

Key words: Zika virus - codon usage biases - proteomics - NS1 protein

Zika virus (ZIKV) was known as a zoonotic pathogen with sporadic human infections in Africa and later in southeastern Asia (Hayes 2009), until the spread of its Asian lineage along the Pacific Islands and Americas, vectored mainly by Aedes aegypti (Musso and CaoLormeau 2015) and marginally by alternative routes of transmission-body fluids, sexual intercourse and perinatal infections. In early 2015, it was detected by molecular techniques in Brazil [Supplementary data (Fig. 1)], where it caused a severe epidemic and produced novel symptoms and post-infection complications (Possas et al. 2017).

Zika fever (ZF) symptoms include persisting arthralgia, headaches and mild fever. The recent ZIKV outbreaks were also associated with a 20 -fold increase in

doi: 10.1590/0074-02760170385

Financial support: FAPESP (project \#2014/17766-9),

CNPq (project 421160/2016-0).

CCMF, Al, CTB and DFLN are supported by FAPESP (\#2014/06090-4,

\#2012/04818-5, \#2014/03911-7 and \#2016/03605-9); GP is supported by FAPESP (grant \#2014/06863); PMAZ held a CNPq scholarship.

+ Corresponding author: pzanotto@usp.br

Received 22 September 2017

Accepted 20 February 2018 cases of Guillain-Barre syndrome (GBS) in French Polynesia, where $98 \%$ of the GBS patients showed anti-ZIKV antibodies (Cao-Lormeau et al. 2016). An increase in the number of GBS cases was also observed in the Brazilian state Bahia, where ZIKV transmission was simultaneous with Dengue virus (DENV) and Chikungunya virus (CHIV). The incidence of ZF-like syndrome reached 328 cases per 100,000 inhabitants from May to August 2015 (Possas et al. 2017). Worryingly, ZIKV was also associated with the abrupt increase of newborns with birth defects (Possas et al. 2017). To date, congenital ZIKV syndrome (CZS) has been causally associated with the Asian lineage of the virus (Cugola et al. 2016) but further studies with other ZIKV lineages are needed.

Viral spillover frequently depends on host adaptation through evolution. One crucial evolutionary mechanism and an indicator of viral adaptation to the host are changes in nucleotide composition (Longdon et al. 2014). Codon usage adaptation after a host shift event could be required to fine-tune the interactions between a virus and a new host (Bahir et al. 2009, Longdon et al. 2014). These changes are not random. Rather, they occur preferentially at interaction sites, such as in viral glycoproteins. Whether these evolutionary changes were 
important for the ZIKV Asian lineage that has spread from Asia to the Americas remains an open question. To better understand aspects of its recent circulation, we investigated evolutionary changes in codon usage of ZIKV lineages, employing sequence analyses and comparative proteomics between African and epidemic Asian lineages.

\section{MATERIALS AND METHODS}

Sequence datasets - We investigated 42 representative, available complete genome sequences of ZIKV from GenBank (www.ncbi.nlm.nih.gov/genbank/) that had information of year and country of isolation (alignment available from: https://github.com/CaioFreire/ CUB). First, we aligned the coding sequences with MACSE program v0.9 (https://bioweb.supagro.inra. $\mathrm{fr} / \mathrm{macse} /$ ) and curated it with AliView v1.171 (http:// ormbunkar.se/aliview/). Since we previously found evidence for recombination in ZIKV from Africa (Faye et al. 2014) and these events could cause potential errors in phylogenetic inferences, we screened for recombination in genomic sequences with the RDP program v4.36 (http://web.cbio.uct.ac.za/ darren/rdp.html). Recombinants (Accession numbers KF383116, KF383117, KF383118 and KU866423) that were identified by more than three independent methods with $p$-value $<0.05$, using Bonferroni correction, were removed of selection and phylodynamic analyses.

Codon preferences analyses - We employed the relative synonymous codon usage method with the R-package Seqin $\{R\}$ v3.13 (http://seqinr.r-forge.r-project.org/) to estimate the codon preferences for each polyprotein gene sequence. In addition, we employed a principal component analysis (PCA) to assess patterns among relative synonymous codon usage (RSCU) values for all the codons, among viral lineages. We identified the most informative codons, which were informative to discriminate among Asian and African lineages, with a biplot graph for the PCA values with the R-package ggbiplot v0.55 (https://github.com/vqv/ggbiplot), using a group probability of 0.95 . The different codon preferences between ZIKV lineages were independently confirmed by high support values $(>80 \%)$ obtained from hierarchical clustering analysis, using the R-package Pvclust v1.32 (http://stat.sys.i.kyoto-u.ac.jp/prog/pvclust/). We also investigated the differences in codon preferences between ZIKV lineages, employing a PCA in codon counts, which were calculated with $\operatorname{Seqin}\{R\}$.

Codon usage biases - We calculated the effective number of codons (ENC) with Emboss v6.60 (http:// emboss.sourceforge.net/) and the proportion of guaninecytosine content in the third base of the codons $\left(\mathrm{GC}_{3}\right)$, using the Seqin $\{R\}$ program to evaluate the codon usage bias (CUB). The theoretical curve of $\mathrm{ENC} \mathrm{x} \mathrm{GC}_{3}$ on the genetic drift was estimated with a Perl script to calculate expected $\mathrm{ENC}$ and $\mathrm{GC}_{3}$ values (available from: https:// github.com/CaioFreire/CUB). We inspected the amino acid content of each gene with Seqin $\{\mathrm{R}\}$ and compared the averages of each amino acid content between the ZIKV lineages with Fisher exact tests.

Codon adaptation of ZIKV genes to humans and Ae. aegypti mosquitoes - In our analysis, CAI is a measure of synonymous CUB based on the codon preference of a viral strain and a codon usage table for a given host. To investigate if the codon usage of ZIKV lineages was similar to the hosts in urban settings, regarding humans and Ae. aegypti, we calculated the codon adaptation index (CAI) for each gene from each ZIKV lineage. Instead of random sampling of human genes to calculate the codon usage table (Cristina et al. 2016) and because the most pronounced biases are in highly expressed genes (Bahir et al. 2009), we used Emboss to calculate a codon usage table for humans (available from: https:// github.com/CaioFreire/CUB) based on 3803 genes identified as housekeeping (Eisenberg and Levanon 2013), which are strongly and uniformly expressed in 16 humans tissues. Moreover, we calculated CAI for Ae. aegypti using the table available in Codon Usage Database

TABLE

Codon adaptation index (CAI) for each gene of Zika virus lineages

\begin{tabular}{|c|c|c|c|c|c|c|}
\hline \multirow[b]{2}{*}{ Gene } & \multicolumn{2}{|c|}{ Median CAI for human } & \multirow[b]{2}{*}{ p-value* } & \multicolumn{2}{|c|}{ Median CAI for Aedes aegypti } & \multirow[b]{2}{*}{ p-value* } \\
\hline & African & Asian & & African & Asian & \\
\hline $\mathrm{C}$ & 0.801 & 0.8 & 0.953 & 0.733 & 0.729 & 0.141 \\
\hline PrM & 0.791 & 0.802 & 5.377E-5 & 0.751 & 0.738 & $5.499 \mathrm{E}-4$ \\
\hline $\mathrm{E}$ & 0.82 & 0.809 & $9.819 \mathrm{E}-6$ & 0.738 & 0.724 & $9.423 \mathrm{E}-6$ \\
\hline NS1 & 0.817 & 0.833 & $1.389 \mathrm{E}-6$ & 0.733 & 0.745 & 8.059E-7 \\
\hline $\mathrm{NS} 2 \mathrm{~A}$ & 0.786 & 0.794 & 0.0502 & 0.71 & 0.732 & $1.021 \mathrm{E}-6$ \\
\hline NS2B & 0.79 & 0.769 & $1.281 \mathrm{E}-6$ & 0.703 & 0.716 & $1.734 \mathrm{E}-5$ \\
\hline NS3 & 0.807 & 0.799 & $7.573 \mathrm{E}-4$ & 0.727 & 0.715 & $1.892 \mathrm{E}-6$ \\
\hline NS4A & 0.776 & 0.775 & 0.8345 & 0.688 & 0.712 & $2.072 \mathrm{E}-6$ \\
\hline NS4B & 0.803 & 0.793 & 2.999E-3 & 0.708 & 0.705 & 0.4896 \\
\hline NS5 & 0.821 & 0.801 & $6.727 \mathrm{E}-7$ & 0.753 & 0.738 & $7.563 \mathrm{E}-7$ \\
\hline
\end{tabular}

*: calculated with Wilcoxon rank sum test. 
(http://www.kazusa.or.jp/codon/). Importantly, the CAI values obtained with our table based on housekeeping genes were very similar to those found with the table from Codon Usage Database with generic human genes. The CAI values for each sequence from ZIKV genes were calculated with CAIcal program (http://genomes. urv.es/CAIcal/). We assessed the confidence of CAI estimates by the calculation of expected CAI values for 1000 random sequences with similar GC-content and the same length of the query sequence. We compared the CAI values between Asian and African lineages with Wilcoxon rank sum test. The sliding window analyses were managed with a Perl script (available from: https:// github.com/CaioFreire/CUB) that used the CAI program from Emboss package v6.6.0 to calculate the CAI values for each window with 25 codons.

Viral culture, amplification and titration - We used a lyophilised ZIKV ( $\mathrm{Z}^{\mathrm{BR}}$ - BeH815744) isolated from a febrile case in the state of Paraiba in the northeast of Brazil isolated in the Evandro Chagas Institute (IEC) in Belém do Pará, Brazil. This virus was reconstituted in $0.5 \mathrm{~mL}$ of sterile diethylpyrocarbonate (DEPC) water. The African-lineage ( $\mathrm{Z}^{\mathrm{AF}}$ - MR-766), which is a reference strain isolated in Uganda in 1947, was provided by the Institute Pasteur in Dakar, Senegal. Both strains were cultured and amplified in cells of Aedes albopictus (C6/36 cells). The C6/36 cells were maintained using Leibovitz's L-15 medium and supplemented with $10 \%$ foetal bovine serum (FBS) (Gibco), 1\% non-essential amino acids (Gibco), 1\% sodium pyruvate (Gibco), 1\% penicillin/streptomycin (Gibco), 0.05\% of amphotericin $\mathrm{B}$ (Gibco). The $\mathrm{C} 6 / 36$ cells were kept at $27^{\circ} \mathrm{C}$ in the absence of $\mathrm{CO} 2$ and tested negative for mycoplasma contamination. After reaching 70\% confluent monolayer, $50 \mu \mathrm{L}$ of $\mathrm{Z}^{\mathrm{BR}}$ was inoculated into $\mathrm{C} 6 / 36$ cells and left adsorb into cells for $1 \mathrm{~h}$, with gentle shaking every 10 min. The cultures were then incubated under the same adsorption conditions. We used the titrated third passage for experimental inoculation (Cugola et al. 2016). The virus titration (in PFU mL-1) of each C6/36 subculture was obtained by plaque assay in porcine kidney epithelial (PS) cells, according to (Cugola et al. 2016). For $Z^{\mathrm{BR}}$, the first C6/36 subculture (T1) had a viral titer of $6 \times$ $10^{8}$. The T2 and T3 subcultures had titers of $7.5 \times 10^{6}$ and $4 \times 10^{12}$, respectively. For $\mathrm{Z}^{\mathrm{AF}}$, the first $\mathrm{C} 6 / 36 \mathrm{sub}-$ culture (T1) had a titer of $1.0 \times 10^{6}$ and $7.5 \times 10^{12}$ in T2 . All the subculture aliquots were stored in cryovials and maintained in liquid nitrogen. For the infections before proteomics we also used third passage inoculum of $\mathrm{Z}^{\mathrm{BR}}$ and a second passage obtained in our lab for $\mathrm{Z}^{\mathrm{AF}}$.

Neurospheres culture - We used a human induced pluripotent stem cell (iPSC) clone that was previously characterised in the Beltrão-Braga and Muotri laboratories (Cugola et al. 2016). This cell line tested negative for mycoplasma contamination. Briefly, high passages of iPSC colonies on feeder-free plates were maintained for five days with mTSeR media (Stem Cell Technologies). On the fifth day, the medium was changed to N2 media (DMEM/ F12 medium supplemented with 1X N2 supplement (Invitrogen) and the dual SMAD inhibitors, $1 \mu \mathrm{M}$ dorsomor- phin (Tocris) and $1 \mu \mathrm{M}$ SB431542 (Stemgent), for $48 \mathrm{~h}$. Further, the colonies were detached from the plate and cultured in suspension as embryoid bodies (EBs) for five days at 90 r.p.m. in N2 media with the dual SMAD inhibitors. The EBs were plated on matrigel-coated plates with NBF media composed of the following: DMEM/F12 media supplemented with $0.5 \mathrm{X} \mathrm{N} 2,0.5 \mathrm{X} \mathrm{B} 27$ supplement (Gibco), 20 ng mL-1 of fibroblast growth factor 2 (FGF2) and $1 \%$ penicillin/streptomycin. The emerged rosettes containing the NPCs were manually picked, dissociated and plated in a double-coated plate with poly-ornithine (10 $\mu \mathrm{g} \mathrm{mL}-1$, Sigma-Aldrich) and laminin (2.5 $\mu \mathrm{g} \mathrm{mL}-1$, Gibco). The NPC population was expanded using NBF media. To produce neurospheres, NPC were scrapped from the plates and submitted to continuous shaking at 90 rpm in NBF medium. All experiments were performed with the approval of the Institute of Biomedical Sciences Ethics Committee (protocol number 1001).

In vitro infection - Neurospheres were infected with $\mathrm{Z}^{\mathrm{BR}}$-BeH815744, $\mathrm{Z}^{\mathrm{AF}}$ - MR-766 and mock (culture supernatant from uninfected C6/36 cells). NPCs were seeded in $100 \mathrm{~mm}$ plates and after $24 \mathrm{~h}$ viral samples were diluted to the desired multiplicity of of infection (MOI) of 10 and added to the cells. For viral adsorption, cells in monolayer were incubated for $1 \mathrm{~h}$ at $4^{\circ} \mathrm{C}$ with gentle agitation every $10 \mathrm{~min}$. Next, the inoculum was removed and cells were washed once with PBS (USB Corporation). Culture medium was added to each well, and cells were incubated at $37^{\circ} \mathrm{C}$ and $5 \% \mathrm{CO} 2$ in constant shaking for the duration of the experiment. For mock controls, the same volume of supernatant was added to each experiment, and the same procedures were followed.

Experimental setup, protein extraction and tryptic digestion - Cells infected with the African ( $\left.\mathrm{Z}^{\mathrm{AF}}-\mathrm{MR}-766\right)$ strain, the Brazilian ( $Z^{\mathrm{BR}}$-BeH815744) viral strain and a mixture of the two viruses were labeled with the neutron encoded TMT 10-Plex, as described below. Three biological replicates for each condition were analysed. In particular, cells infected with the African strain were labeled with $126,127 \mathrm{~N}$ and $127 \mathrm{C}$. Cells infected with the Brazilian strain were labeled with $128 \mathrm{C}, 128 \mathrm{~N}$ and $129 \mathrm{C}$. Cells infected with a mixture of the two viruses were labelled with $129 \mathrm{~N}, 130 \mathrm{C}$ and $130 \mathrm{~N}$. Further details on the labeling protocol are reported below. Two million cells per condition were lysed in $500 \mathrm{uL}$ of HENS buffer containing 100 mM HEPES ( $\mathrm{pH}$ 7.8), 1 mM EDTA, $0.1 \mathrm{mM}$ Neocuproine, and $1 \%$ sodium docecyl sulfate (SDS) with the addition of protease and phosphatase inhibitors. In order to block free cysteines, $\mathrm{N}$-ethyl maleimide was added $(40 \mathrm{mM})$. The cell lysate was incubated for $20 \mathrm{~min}$ on ice before the addition of four volumes of ice-cold acetone. The mixture was incubated overnight at $-20^{\circ} \mathrm{C}$. Protein were centrifuged at $14000 \mathrm{~g}$ for $10 \mathrm{~min}$. Protein pellet was re-suspended in 8 $\mathrm{M}$ urea in $100 \mathrm{mM}$ TEAB and proteins quantified using Qubit (Invitrogen). Disulfide bonds were reduced with 10 $\mathrm{mM}$ dithiothreitol DTT and alkylated with $40 \mathrm{mM}$ IAA. Proteins were digested with trypsin at 1:50 enzyme: substrate ratio. Tryptic peptides were desalted with Oasis HLB (Waters) before quantification using Qubit. 
Peptide labelling with neutron encoded TMT 10-Plex - One hundred micrograms of peptides were labeled with TMT 10-plex (Thermo Fisher Scientific) according to manufacturer instructions. Briefly, peptides were resuspended in $20 \mathrm{mM}$ TEAB and the TMT 10-plex reagent, dissolved in acetonitrile, was added. After $1 \mathrm{~h}$, the reaction was blocked with hydroxylamine, incubated for 15 min before the different conditions were combined in a 1:1:1:1:1:1:1:1:1 proportion. The combined peptide mixture was desalted using reversed-phase microcolumns before hydrophilic interaction chromatography (HILIC) fractionation, as previously described (Palmisano et al. 2010).

Nanoscale liquid chromatography coupled to tandem mass spectrometry analysis - Each HILIC fraction was dried in vacuum and resuspended in $0.1 \%$ formic acid in water. The sample was injected into an EasynanoLC 1000 (Thermo Fisher Scientific) coupled to a Q Exactive (Thermo Fisher Scientific). Peptides were initially loaded onto a precolumn $3.5 \mathrm{~cm}$ x $100 \mathrm{um}$ (i.d.) and separated on custom-made $18 \mathrm{~cm} \times 75 \mu \mathrm{m}$ (i.d.) reversed-phase columns (Reprosil). Gradient elution was performed from $0 \%$ acetonitrile to $28 \%$ acetonitrile in $0.1 \%$ formic acid over $52 \mathrm{~min}$ up to $45 \%$ acetonitrile to $57 \mathrm{~min}$. The total length of the run was set to $70 \mathrm{~min}$. The instrument was operated with a data dependent top 15 method. Mass spectrometry (MS) spectra were acquired using a $\mathrm{Q}$ Exactive instrument 120.000 resolution in a range of $400-1600 \mathrm{~m} / \mathrm{z}$ and HCD scans at 30.000 resolution (at $\mathrm{m} / \mathrm{z} 200$ ). The MS ion target was 3e6. MS2 ion target was set to $1 \mathrm{e} 5$ with a maximum injection time of $150 \mathrm{~ms}$ and isolation window of $1.2 \mathrm{~m} / \mathrm{z}$. The raw files are available from the authors upon request.

Database search - Raw data were searched with MaxQuant (Cox and Mann 2008) and the database search engine Andromeda. Uniprot database contained human proteins, Zika virus proteins (PE_243 and MR_766) and common contaminants. MS accuracy was set to $4.5 \mathrm{ppm}$ and MS/MS accuracy to $20 \mathrm{ppm}$. Trypsin was set as cleavage enzyme with two missed cleavages. Carbamidomethylation of cysteine, N-ethyl maleimide of cysteine and oxidation of methionine were set as variable modifications. All identifications were filtered in order to achieve a FDR of less than $1 \%$. Protein/peptide quantification was performed using the reporter ion MS2 module with the TMT 10-plex, embedded in the MaxQuant software. Protein quantification was performed using razor and unique peptides. Reporter ion intensities were given and assembled into the protein intensity. Each reporter ion intensity was corrected and normalised for the total intensity, so any bias due to sample loading was corrected. After excluding peptides identified as potential contaminants or in reverse database, peptides belonging to the ZIKV were manually filtered and analysed. The relative protein expression was assembled using the top 3 most intense peptides for each protein. Some proteins such as NS2A, NS2B and NS3 were identified with a single peptide. The ratio of proteins identified and quantified in neurospheres infected with $Z^{\mathrm{BR}}$ and $\mathrm{Z}^{\mathrm{AF}}$ was reported. In order to check for sample variability between the different biological replicates, the $\log 2$ (Intensity) for each protein was compared and reported as a scatter plot. The three biological replicates of neurospheres infected with $\mathrm{Z}^{\mathrm{AF}}(\mathrm{A} 1, \mathrm{~A} 2$ and $\mathrm{A} 3)$ and three biological replicates of neurospheres infected with $Z^{\mathrm{BR}}$ (B1, B2 and B3) were compared [Supplementary data (Fig. 9)].

Selection analyses - We investigated the selective regime of the polyprotein codon sites, calculating the difference $(\mathrm{w})$ between the estimates of non-synonymous $(\mathrm{dN})$ and synonymous $(\mathrm{dS})$ substitution rates per codon site. The $\mathrm{w}$ values were estimated with single likelihood ancestor counting (SLAC), fast unbiased Bayes approximation (FUBAR), mixed effects model of evolution (MEME) and fixed effect likelihood (FEL) method with HyPhy program v2.11 (Pond et al. 2005), assuming a significance level (a) of 0.05 . We used a maximum likelihood (ML) phylogenetic tree, inferred with GARLI v2.01 (https://code.google.com/archive/p/garli/), on polyprotein gene alignment without recombinant sequences. Codon sites under purifying selection were revealed by $\mathrm{w}<$ 0 , and the opposite is indicative of diversifying selection. With HyPhy, we chose the best-fit substitution model (012342), based on Akaike information criterion. In addition, we calculated the Spearman coefficient of correlation between mean CAI (for Aedes and human) and posterior mean synonymous substitution rate estimated with FUBAR (the method that identified more sites under purifying selection) for each codon in ZIKV genes (data available from: https://github.com/CaioFreire/CUB).

Phylodynamic analyses - Using the dates of isolation, we estimated a coarse substitution rate per site per year ( $\mu$ ) using Path-O-Gen v1.4 (http://tree.bio.ed.ac.uk/ soltware/patho- gen/) with the ML tree for non-recombinant genomic sequences (alignment available from: https://github.com/CaioFreire/CUB). We used BEAST program v1.82 (Drummond et al. 2012), with the estimated evolutionary rate prior $(\mathrm{m}=4.8 \mathrm{E}-4 \pm 2 \mathrm{E}-4$ substitution/site/year) under a relaxed lognormal molecular clock and a GTR $+\mathrm{G}+\mathrm{I}$ substitution model to infer a timescaled maximum clade credibility (MCC) tree and investigate the demographic dynamics of ZIKV lineages with the Bayesian Skyride method to estimate the temporal dynamics of effective population size (Ne.g) of ZIKV, which approximates the number of infections in time. To reveal the dynamics of viral population size growth, we calculated the Malthusian fitness $\left(\mathrm{W}_{\mathrm{M}}\right)$, which was approximated by the ratio of the population size in sequential time points $\left(\mathrm{W}_{\mathrm{M}}=\mathrm{Ne} \cdot \mathrm{g}_{\mathrm{t}} / \mathrm{Ne} \cdot \mathrm{g}_{\mathrm{t}-1}\right)$.

Ethics - We used human iPSC, generated by cellular reprograming of Stem Cells from Human Exfoliated Deciduous Teeth (SHED), whose subjects were recruited through The Tooth Fairy Project initiative (University of São Paulo - USP), with the approval of the Ethics Committee of the Institute of Biosciences CEP-ICB/ USP (Protocol CEP/ICB-USP 1001). After a complete description of this research, parents provided written informed consent for their participation.

\section{RESULTS}

Codon preferences of ZIKV lineages are distinct Preferences of synonymous codons can strongly affect 


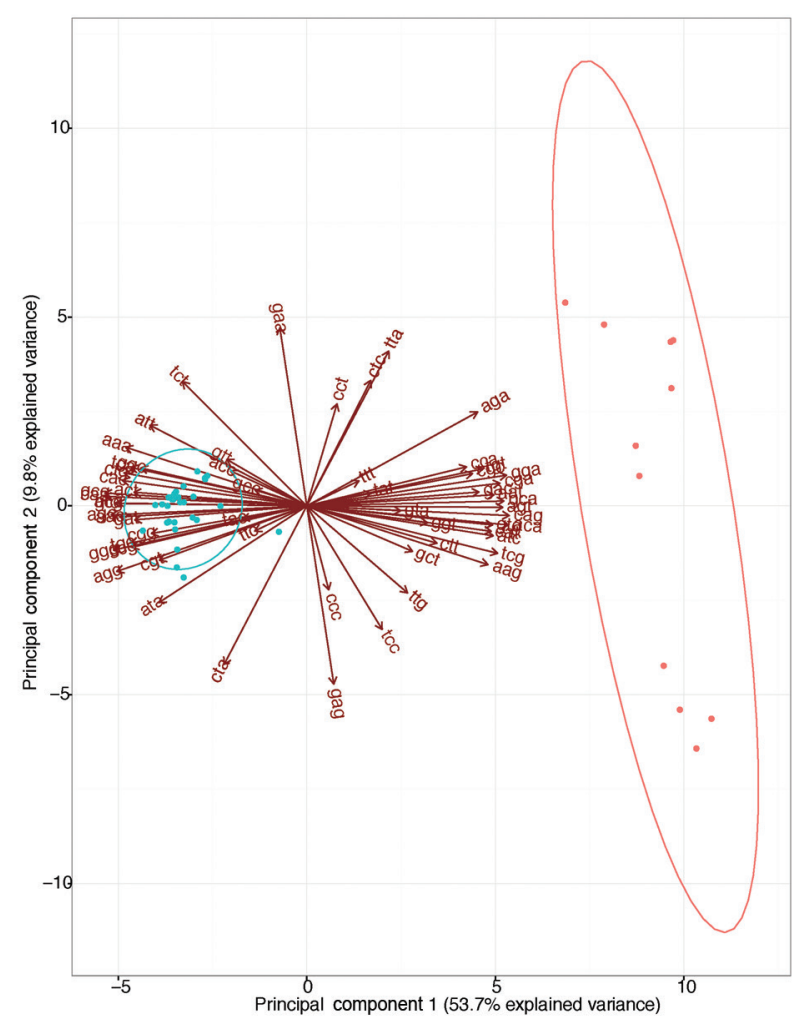

Fig. 1: relative synonymous codon usage analysis (RSCU) for the polyprotein coding region shows that the principal component analysis (PCA) based on RSCU agrees with the phylogenetic distinctions between the two Zika virus (ZIKV) lineages. The African (red) and Asian (blue) lineages were colour-coded accordingly. The biplot arrows indicate the preferred codons from each lineage. The ellipses delimit the groups with $95 \%$ of confidence on the biplots for PCA based on the preferential usage of codons that is lineage-specific.

gene expression, which correlates with differences in infectivity. Thus, we estimated the RSCU values for each ZIKV polyprotein gene sequence (Fig. 1). By means of PCA for RSCU values, we found distinct preferences of synonymous codons in the African and Asian lineages for the entire polyprotein (Fig. 1) and for each viral gene sequences [Supplementary data (Fig. 2)]. The findings suggested an evolutionary change in codon preferences that agree with the phylogeny of ZIKV. The distinct preferences between ZIKV lineages were also observed in the analysis by absolute values of codon counts (data available from: https://github.com/CaioFreire/CUB). The extent of this codon bias was inferred by plotting the ENC that is a measure of the amount of codon preferences, ranging from 20 (extremely biased) to 61 (synonymous codons have the same probability of being used), versus the proportion of GC-content in the third position for each codon, which revealed different codon usage biases among ZIKV genes [Supplementary data (Figs 3-4)].

ZIKV codons are under purifying selection - We found several codon sites under purifying selective pressure (Wright 1990) [Supplementary data (Fig. 5)]. This strong purifying selection (changes on synonymous codons) was also observed for other arboviruses (Jenkins et al. 2001) and is mostly attributed to the alternation between vectors and vertebrate hosts. We also found four codons under diversifying selection, using FEL and MEME methods, which favors changes in amino acid content. Two of them were found in in the NS4B gene and the other in the NS5 (positions 2280th, 2449th, 2749 th and 2807th in our alignment for the complete polyprotein gene). The MEME method revealed that 2280 th and 2449th polyprotein sites were under diversifying selection $100 \%$ of the time, 2749th site was under diversifying selection $46 \%$ and 2807 th was under diversifying selection in $14 \%$ of the tie. In addition, the proportion of negatively selected sites, i.e., under purifying selection, detected with the FEL method was similar among ZIKV genes $\left(\chi^{2}=7.52\right.$ and $p$-value $=0.58$ in Pearson's Chi-squared test with 9 degrees of freedom). Our comparisons of amino acid content showed no differences between the African and Asian ZIKV lineages $(\mathrm{p}$-value $=1)$, obtained from the Fisher exact tests for each viral protein (C, PrM, E, NS1, NS2A, NS2B, NS3, NS4A, NS4B and NS5), in agreement with the findings that ZIKV lineages constitute a single serotype.

Codon adaptation is different in the genes of ZIKV lineages - Given that only the Asian lineage is associated to large human outbreaks and because we found significant distinct preferences of synonymous codons between ZIKV lineages (Fig. 1), we further compared virus codon adaptation to host and vector using $A e$. aegypti and human housekeeping genes. We analysed the genes separately (Table, Fig. 2), since the viral polyprotein is cleaved during and post-translation (Lindenbach and Rice 2003) and the polyprotein codon usage among ZIKV strains was shown to be slightly biased (Cristina et al. 2016). We found that recent Asian epidemic lineages had a stronger codon bias in the NS1 gene (Freire et al. 2015), as indicated by its increase in codon adaptation index (CAI, blue curves in Fig. 2) (Sharp and Li 1987). Moreover, NS1 was significantly better adapted simultaneously to humans and Ae. aegypti hosts [Table, Fig. 2, Supplementary data (Fig. 7D)]. The PrM gene in the Asian lineages was well adapted to human codon usage [Fig. 2A, Supplementary data (Fig. 7)] but not for Ae. aegypti [Table, Fig. 2B, Supplementary data (Fig. 7B)]. On the other hand, we found that NS2A, NS2B and NS4B from the Asian lineage were significantly better adapted to Ae. aegypti compared to their homologues in the African lineage [Table, Fig. 2B, Supplementary data (Fig. 7)] and not to the human codon usage (Table). Importantly, in the African lineage we found that the NS4A, E and NS5 genes were significantly better adapted to humans, and the last two are also more adapted to Ae. aegypti. These conclusions were obtained by measurements of CAI for each ZIKV gene for both lineages, unveiling potential viral adaptation to cellular translation machinery of man and mosquitoes. Furthermore, by measuring CAI for the entire polyprotein [Supplementary data (Fig. 6)], we observed that all ZIKV strains appear to be significantly adapted to humans while they were less adapted to the Ae. aegypti mosquitoes (CAI values above threshold), as found for randomly sampled human genes (Cristina et al. 2016). Codons with high CAI were under 

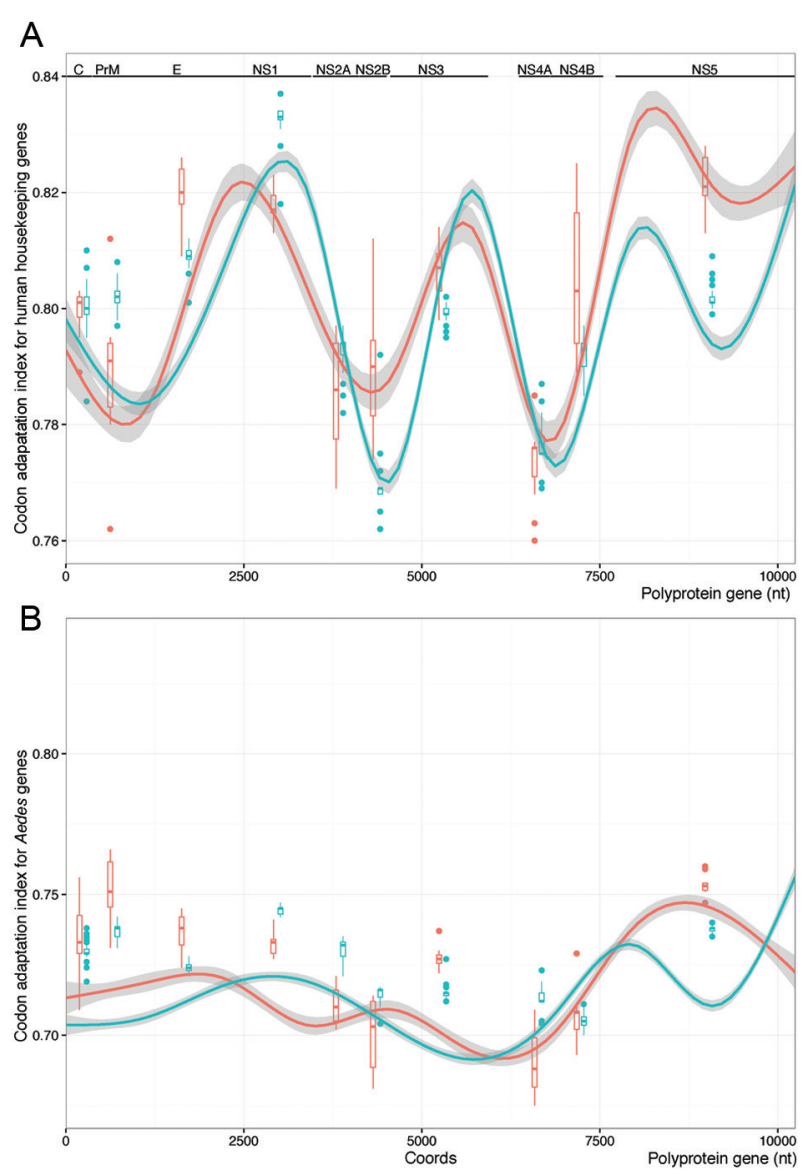

Fig. 2: codon adaptation index (CAI) for Zika virus (ZIKV) genes. (A) Distribution of CAI values calculated with codon usage table based on human housekeeping genes for each ZIKV gene. (B) CAI values based on Aedes aegypti genes. The African (red) and Asian (blue) lineages are colour-coded accordingly. The curves show sliding-window of the CAI analyses results for both, (i) the complete ZIKV polyprotein open reading frame and (ii) for each individual gene shown in colour-coded boxplots. Median, 1st and 3rd quartiles are shown in boxes and the whiskers represent the interquartile range times 1.5 .

strong purifying selection [Supplementary data (Fig. 8)] and we found no significant positive correlation between purifying selection and codon adaptation [Supplementary data (Table)].

Viral population size increase coincides with the beginning of the recent ZIKV epidemic - We observed an abrupt increase (Fig. 3B) in Malthusian fitness $\left(\mathrm{W}_{\mathrm{M}}\right)$, which corresponds to variation in viral population sizes between succeeding time points, in 2013 that coincides with the breakthrough epidemic and long human-to-human chains in Pacific Islands. Crucially, all strains associated with the Asian lineage [Supplementary data (Fig. 1)] causing the recent epidemic have higher NS1 CAI values for humans than former sylvatic viruses [Fig. 3A, Supplementary data (Fig. 1)]. Our phylodynamic analyses also suggested that these codon optimisations could have happened after 1950 [Supplementary data (Fig. 1)], because CAI for the former Malaysian strain is smaller than recent Asian strains. Moreover, codon adaptation for humans in the NS1 coding re- gion from the recent Asian lineage showed a clear increase near the present (Fig. 3A), which coincides with its spread in the Pacific and America. The strong bias in codon usage that we observed only for NS1 from epidemic strains in both hosts is suggestive of translational selection acting on this gene [Supplementary data (Fig. 7D)].

ZIKV lineages have differences in replication and protein production - We infected neural progenitor cells (NPC) with Brazilian $\left(\mathrm{Z}^{\mathrm{BR}}\right)$ and African $\left(\mathrm{Z}^{\mathrm{AF}}\right)$ ZIKV strains at MOI 10. Infection with both viruses presented noticeable cytopathic effect and at 24 pi yielded total RNA that was used for viral quantification by real-time polimerase chain reaction $(\mathrm{PCR})$ with $\mathrm{Cts}$ of $24.7\left(\mathrm{Z}^{\mathrm{BR}}\right)$ and $31.7\left(\mathrm{Z}^{\mathrm{AF}}\right)$ that amounted to 1874 and 16 viral copies per ng RNA, respectively. We then compared proteins that differ from the ratios expected of the individual proteins in the viral polyprotein (Fig. 4). Our experiments indicated that $Z^{\mathrm{BR}}$ produced more NS1 ( 4-fold), NS2B ( 7-fold) and E ( $\sim 3.5$-fold) proteins than $\mathrm{Z}^{\mathrm{AF}}$ and equal ratios of NS2A and NS3.

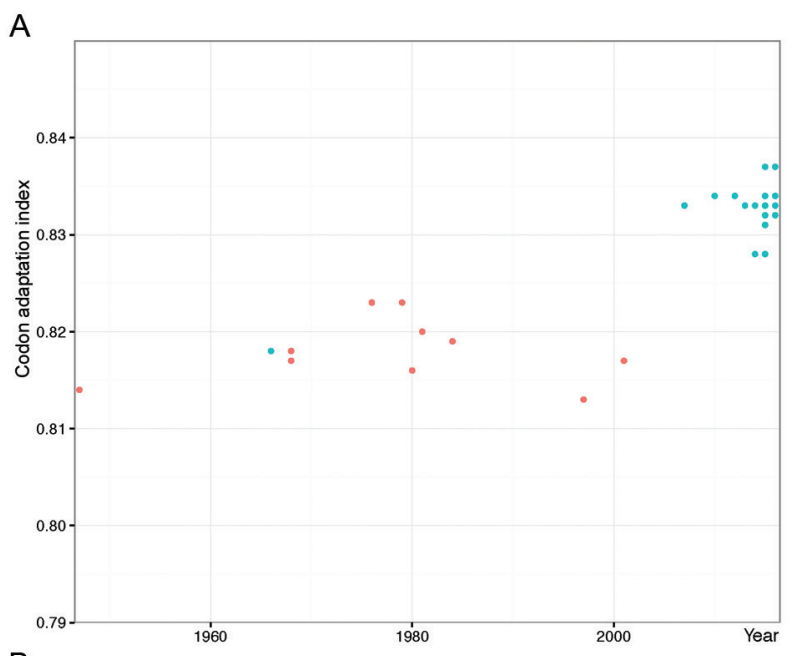

B

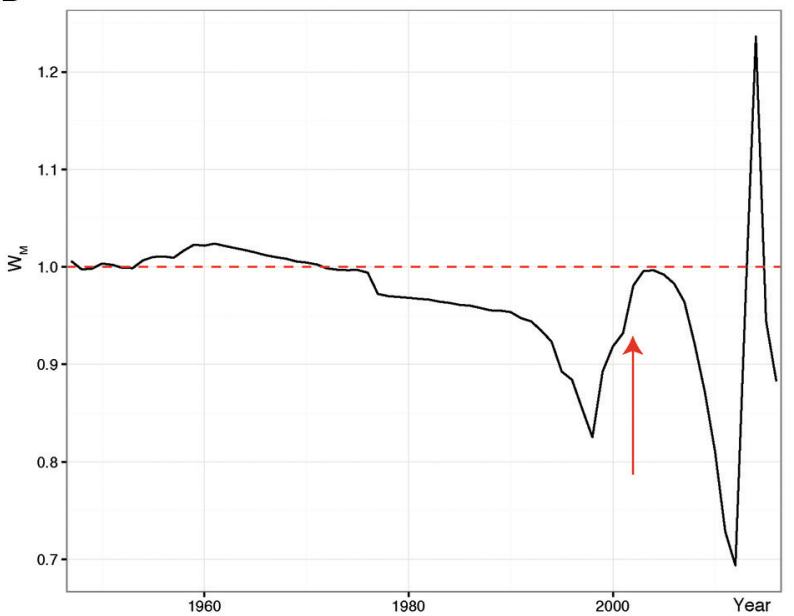

Fig. 3: NS1 gene codon usage and demographic dynamics of Zika virus (ZIKV). (A) NS1 gene codon adaptation index (CAI) to the human housekeeping genes for the African (red dots) and Asian (blue dots) lineages. (B) Malthusian fitness $\left(W_{M}\right)$ estimated for ZIKV since 1947, representing decrease $\left(w_{M}<1\right)$, constant population size $\left(w_{M}=1\right)$, and net growth $\left(w_{M}>\right.$ 1). The red arrow indicates the end of African lineage sampling. 


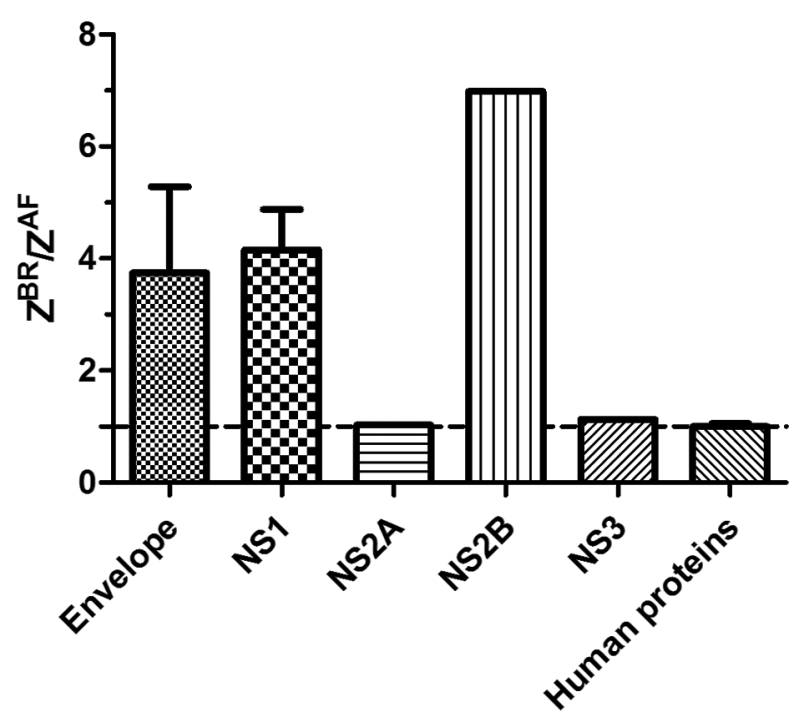

Fig. 4: stoichiometric ratio between proteins produced during infection experiments with the African $\left(\mathrm{Z}^{\mathrm{AF}}\right)$ and Brazilian $\mathrm{ZIKV}\left(\mathrm{Z}^{\mathrm{BR}}\right)$ lineage analysed by mass spectrometry-based proteomics. Tryptic peptides were quantified using TMT10plex isobaric labeling and assembled into proteins. The relative expression of each viral protein from $Z^{\mathrm{BR}}$ and $\mathrm{Z}^{\mathrm{AF}}$ lineages were reported as $Z^{\mathrm{BR}} / \mathrm{Z}^{\mathrm{AF}}$ ratio. The relative expression of 4842 human proteins identified in neurospheres infected with $Z^{\mathrm{AF}}$ and $\mathrm{Z}^{\mathrm{BR}}$ was reported (data available from: https:/github.com/CaioFreire/CUB). The average ratio $\left(\mathrm{Z}^{\mathrm{BR}} \mathrm{vs} \mathrm{Z}^{\mathrm{AF}}\right)$ of the human proteins is equal to 1 .

\section{DISCUSSION}

Silent selection on ZIKV - Synonymous mutations are a common source of variation, given the constrained non-synonymous substitutions rate imposed to RNA viruses that have to negotiate successful infections, alternating between humans and mosquitoes. Assuming codons as evolutionary units of selection, we could explain CAI heterogeneity along the genome due to silent selection, in a similar fashion as the fixation of specific amino acid replacements due to drift or positive selection, once they confer selective advantage to the organism (Brandis and Hughes 2016). Nevertheless, during cell line infection, a single polypetide is expected to be produced from the complete ORF encoded by the viral genomic RNA and this is assumed as the canonical mechanism of translation in the genus Flavivirus. Therefore, there is no clear explanation for how selection would act preferentially at some codons of specific ZIKV genes that are believed to be co-replicated and are believed to be co-translated. Given the observed differences in CAI and the stoichiometric differences found among viral proteins, other aspects could to be considered. For example, the complex biology of these viruses that infect several tissues of insects and vertebrates, several mechanisms could account for translational selection being applied differently at different portions of the polyprotein. These could include both replicative and translational processivity differences, for example. In this regard, the genomic organisation of flaviviruses has the structural proteins, which are usually necessary in larger amounts for viral morphogenesis, positioned in a way that they are translated before the nonstructural proteins, mostly enzymes necessary in lesser amounts than the structural proteins.

It is noteworthy that NS1 is also necessary in large amounts and is located at the border between structural and non-structural genes. Interestingly, an internal translation initiation was postulated for Flavivirus RNA downstream form the NS1 (Westaway 1977), possibly at a secondary ribosomal attachment site, on the basis of ultraviolet inactivation experiments with the Kunjin virus (Westaway et al. 1984). A pseudoknot at the coding region for the C-terminal of the WNV NS1 is associated with a -1 ribosomal frame shift leading to the translation of a longer form of NS1 (Brinton 2013). Moreover, noncanonical, 5' cap-independent translation initiation has been shown for DENV (Edgil et al. 2006) and initiation at non 5' proximal AUG triplets is a common feature of two other genera (Hepacivirus and Pestivirus) of the family Flaviviridae. These features could account for decoupling selective forces among genes of flaviruses in general and ZIKV in particular.

Biological correlates of codon usage in ZIKV - The higher values of CAI and the higher viral loads produced by $\mathrm{Z}^{\mathrm{BR}}$ compared to $\mathrm{Z}^{\mathrm{AF}}$ in NPC cells did agree with the ratios observed in our proteomics data for NS1 (Fig. 4). Accordingly, we detected more viral proteins in NPC infected by $Z^{\mathrm{BR}}$ than by $Z^{\mathrm{AF}}$. However, these differences were not exclusively explained by the differences in titration between the viral lineages. We detected equal proportions of NS2A and NS3 proteins, but a relative increase in NS1, NS2B and E proteins in $Z^{\text {BR }}$ infected cells (Fig. 4). The differences in ratio could also be explained by stability differences in the proteins being produced in the two viral lineages. Nevertheless, the agreement of CAI values and stoichiometric ratios could also entail translational efficiency differences. It has been shown that codon usage composition correlates with observed variability in protein:transcript ratios. Moreover, viral codon usage optimisation was also shown to be associated with fine-tuning viral host interactions (Longdon et al. 2014) and the most affected viral genes are usually those highly expressed (Bahir et al. 2009). It is noteworthy that the NS1 protein is secreted by infected cells as hexamers that are implicated in immune evasion strategies by blocking complement-mediated responses during infection in humans and, as a dimers, plays an important role in viral replication (Müller and Young 2013), suggesting a possible advantage for NS1 increased production.

Crucially, codon adaptation is more critical for human viruses than for viruses that infect other mammals (Bahir et al. 2009), which could be the case of the recent epidemic Asian ZIKV lineage in contrast to the African lineage. Although our experimental data agrees with our results on different CAI values for NS1, the differences in the stoichiometry of ZIKV proteins we observed indicate that additional factors, e.g., differences in protein stability could be implicated. The lower CAI for Ae. aegypti that we observed for all ZIKV genes could be associated to the use of Ae. aegypti as ZIKV vector in South and 
Central America (Chouin-Carneiro et al. 2016), while several other Aedes spp. mosquitoes are its vectors in Africa and ZIKV transmission by Ae. aegypti from Africa is insignificant (Diagne et al. 2015). Moreover, Ae. aegypti from the Americas was shown to have low competence for ZIKV in the laboratory (Chouin-Carneiro et al. 2016). The elevated CAI for humans compared to mosquitoes has also to be considered under the perspective of a possible role of persistence in humans, since ZIKV was shown to be present and transmissible in semen (Barzon et al. 2016), and other modes of transmission.

Moreover, the recent spread of ZIKV to French Polynesia and the Americas has been associated to unusual increase in congenital malformation (e.g., microcephaly) and GBS reporting (Ioos et al. 2014). Although we show: (i) some evidence of changes in codon usage in Asian lineage of ZIKV, which were independently confirmed (Cristina et al. 2016), (ii) our additional proteomics findings on stoichiometric differences between these lineages and (iii) given that they constitute a single serotype; it remains to be shown if CZS is a specific outcome of the infection by the Asian lineage in the Americas.

\section{ACKNOWLEDGEMENTS}

To Dr Ricardo Palacios from Butantã Institute for the critical comments and the critical revisions.

\section{AUTHORS' CONTRIBUTION}

CCMF, AI, DFLN, AAS, GP, PBB, and PMAZ designed the experiments and wrote the paper; CCMF, GP, CTB, FC, FBR, PBB, LRF, MRL and DFLN conducted the experiments; CCMF, AI, DFLN and PMAZ prepared the figures. The authors declare no competing financial interests.

\section{REFERENCES}

Bahir I, Fromer M, Prat Y, Linial M. Viral adaptation to host: a proteome-based analysis of codon usage and amino acid preferences. Mol Syst Biol. 2009; 5: 311.

Barzon L, Pacenti M, Franchin E, Lavezzo E, Trevisan M, Sgarabotto $\mathrm{D}$, et al. Infection dynamics in a traveller with persistent shedding of Zika virus RNA in semen for six months after returning from Haiti to Italy, January 2016. Euro Surveill. 2016; 21(32): 1-4.

Brandis G, Hughes D. The selective advantage of synonymous codon usage bias in Salmonella. PLoS Genet. 2016; 12(3): e1005926.

Brinton MA. Replication cycle and molecular biology of the West Nile virus. Viruses. 2013; 6(1):13-53.

Cao-Lormeau V-M, Blake A, Mons S, Lastère S, Roche C, Vanhomwegen J, et al. Guillain-Barré syndrome outbreak associated with Zika virus infection in French Polynesia: a case-control study. Lancet. 2016; 387(10027): 1531-9.

Chouin-Carneiro T, Vega-Rua A, Vazeille M, Yebakima A, Girod R, Goindin D, et al. Differential susceptibilities of Aedes aegypti and Aedes albopictus from the Americas to Zika virus. PLoS Negl Trop Dis. 2016; 10(3): 1-11.

Cox J, Mann M. MaxQuant enables high peptide identification rates, individualized p.p.b.-range mass accuracies and proteome-wide protein quantification. Nat Biotechnol. 2008; 26(12): 1367-72.

Cristina J, Fajardo A, Soñora M, Moratorio G, Musto H. A detailed comparative analysis of codon usage bias in Zika virus. Virus Res. 2016; 223: 147-52.
Cugola FR, Fernandes IR, Russo FB, Freitas BC, Dias JLM, Guimarães KP, et al. The Brazilian Zika virus strain causes birth defects in experimental models. Nature. 2016; 534: 267-71.

Diagne CT, Diallo D, Faye O, Ba Y, Faye O, Gaye A, et al. Potential of selected Senegalese Aedes spp. mosquitoes (Diptera: Culicidae) to transmit Zika virus. BMC Infect Dis. 2015; 15(1): 492.

Drummond AJ, Suchard MA, Xie D, Rambaut A. Bayesian phylogenetics with BEAUti and the BEAST 1.7. Mol Biol Evol. 2012; 29(8): 1969-73.

Edgil D, Polacek C, Harris E. Dengue virus utilizes a novel strategy for translation initiation when cap-dependent translation is inhibited. J Virol. 2006; 80(6): 2976-86.

Eisenberg E, Levanon EY. Human housekeeping genes, revisited. Trends Genet. 2013; 29(10): 569-74.

Faye O, Freire CCM, Iamarino A, Faye O, de Oliveira JVC, Diallo M, et al. Molecular evolution of Zika virus during its emergence in the 20th century. Bird B, editor. PLoS Negl Trop Dis. 2014; 8(1): e2636.

Freire CCM, Iamarino A, de Lima Neto DF, Sall AA, Zanotto PMA. Spread of the pandemic Zika virus lineage is associated with NS1 codon usage adaptation in humans. bioRxiv. 2015; doi: http:// dx.doi.org/10.1101/032839.

Hayes EB. Zika virus outside Africa. Emerg Infect Dis. 2009: 15(9): 1347-50.

Ioos S, Mallet H-P, Goffart IL, Gauthier V, Cardoso T, Herida M. Current Zika virus epidemiology and recent epidemics. Med Mal Infect. 2014; 44(7): 302-7.

Jenkins GM, Pagel M, Gould E, Zanotto PMA, Holmes EC. Evolution of base composition and codon usage bias in the genus Flavivirus. J Mol Evol. 2001; 52(4): 383-90.

Lindenbach BD, Rice CM. Molecular biology of flaviviruses. Adv Virus Res. 2003; 59: 23-61.

Longdon B, Brockhurst M, Russell C, Welch JJ, Jiggins FM. The evolution and genetics of virus host shifts. PLoS Pathog. 2014; 10(11): e1004395.

Müller D, Young PR. The flavivirus NS1 protein: molecular and structural biology, immunology, role in pathogenesis and application as a diagnostic biomarker. Antiviral Res. 2013; 98(2): 192-208.

Musso D, Cao-Lormeau V-M. Zika virus : following the path of dengue and chikungunya ? Lancet. 2015; 386(9990): 243-4.

Palmisano G, Lendal SE, Engholm-Keller K, Leth-Larsen R, Parker BL, Larsen MR. Selective enrichment of sialic acid-containing glycopeptides using titanium dioxide chromatography with analysis by HILIC and mass spectrometry. Nat Protoc. 2010; 5(12): 1974-82.

Pond SLK, Frost SDW, Muse SV. HyPhy: hypothesis testing using phylogenies. Bioinformatics. 2005; 21(5): 676-9.

Possas C, Brasil P, Marzochi MCA, Tanuri A, Martins RM, Marques ETA, et al. Zika puzzle in Brazil: peculiar conditions of viral introduction and dissemination - A Review. Mem Inst Oswaldo Cruz. 2017; 112(5): 319-27.

Sharp PM, Li WH. The codon adaptation index-a measure of directional synonymous codon usage bias, and its potential applications. Nucleic Acids Res. 1987; 15(3): 1281-95.

Westaway EG, Speight G, Endo L. Gene order of translation of the flavivirus Kunjin: further evidence of internal initiation in vivo. Virus Res. 1984; 1(4): 333-50.

Westaway EG. Strategy of the flavivirus genome: evidence for multiple internal initiation of translation of proteins specified by Kunjin virus in mammalian cells. Virology. 1977; 80(2): 320-35.

Wright F. The "effective number of codons" used in a gene. Gene. 1990; 87(1): 23-9. 